UNIVERSIDAD NACIONAL DE LA PLATA (UNLP)

FACULTAD DE CIENCIAS JURIDICAS Y SOCIALES

MAESTRIA EN INTELIGENCIA ESTRATEGICA NACIONAL SIGLO XXI

TESIS

TITULO:

"Bolivia como nuevo epicentro del Narcotráfico en Sudamérica y su incidencia en Argentina"

TUTOR: PROF. SILVIA BEATRIZ CUCOVAZ

AUTOR: JOSE ARIEL BARRERA

AÑO: 2015 
Agradezco a mi familia por el apoyo incondicional en cada una de mis decisiones, a mi pequeño hijo por dejarme robarle su tiempo para poder terminar lo que empecé. También debo agradecer a la casa de estudios me que formo en estos últimos años y al cuerpo de profesores quienes compartieron sus conocimientos con sus alumnos. Espero que este simple escrito sea un aporte para la toma de decisiones, debiendo en un fututo ser actualizado y perfeccionado 


\section{TEMA DE TESIS:}

"BOLIVIA COMO NUEVO EPICENTRO DEL NARCOTRAFICO EN SUDAMERICA Y SU IMPACTO EN LA ARGENTINA"

\section{RESUMEN:}

El presente trabajo de investigación intenta estudiar, analizar y describir la situación actual del narcotráfico en la Republica Plurinacional de Bolivia, para tratar de determinar si dicho país puede ser considerado como "el nuevo epicentro del narcotráfico en Sudamérica", de igual modo intentamos establecer si esta coyuntura en la cual está inmersa Bolivia afecta directa o indirectamente el comportamiento del narcotráfico en nuestro país.

Por tal motivo partimos de la siguiente hipótesis:

"La producción de droga en Bolivia, su cercanía con otros países productores, la facilidad de las comunicaciones, la corrupción, la carencia de legislación adecuada y otras debilidades propias del sistema político del vecino país la convierten en el epicentro del narcotráfico que afecta a nuestro país".

Para lograr el objetivo final de esta tesis se desarrollaron $\mathbf{V}$ capítulos, a los cuales podemos describir brevemente de la siguiente manera:

Capítulo I: CONSIDERACIONES Y CONCEPTOS BASICOS. DEFINICION DE CRIMEN ORGANIZADO. EL NARCOTRAFICO COMO TIPOLOGIA DELICTUAL DEL CRIMEN ORGANIZADO. RESEÑA SOBRE LABOR E IMPORTANCIA DE NACIONES UNIDAS EN EL CONTEXTO MUNDIAL. LEGISLACION INTERNACIONAL. BREVE RESEÑA Y COMENTARIOS SOBRE LA LEGISLACION EN RELACION AL NARCOTRAFICO EN ARGENTINA. LA GUERRA CONTRA LAS DROGAS, ANTECEDENTES Y ORIGENES. ANTECEDENTES A LA LEY 23.737. POSTURA DE BOLIVIA ANTE LA LEGISLACION INTERNACIONAL Y LEGISLACION INTERNA VIGENTE. MARCO INSTITUCIONAL ACTUAL. LA HOJA DE COCA EN BOLIVIA.

Capitulo II: EL NARCOTRAFICO EN EL CONTEXO DEL CRIMEN ORGANIZADO INTERNACIONAL. CONCEPTUALIZACION DEL CRIMEN ORGANIZADO INTERNACIONAL. CRIMEN ORGANIZADO Y NARCOTRAFICO. EL NARCOTRAFICO 
COMO NUEVA PROBLEMÁTICA MUNDIAL. EL NARCOTRAFICO DESDE UNA PERPECTIVA INTERNACIONAL.

Capitulo III: ESTADO ACTUAL DEL NARCOTRAFICO EN BOLIVIA. POSTURA BOLIVARIANA EN LA LUCHA CONTRA EL NARCOTRAFICO. REFORMA DE LA LEY 1008. LA NACIONALIZACION DE LA LUCHA CONTRA EL NARCOTRAFICO. CULTIVO VS ERRADICACION DE HOJA DE COCA. PRODUCCION POTENCIAL DE COCAINA. DEMOGRAFICA DE LA HOJA DE COCA. MONITOREO DE LA HOJA DE COCA EN BOLIVIA. BOLIVIA COMO NUEVO EPICENTRO DEL NARCOTRAFICO EN SUDAMERICA. FUERZAS ESPECIALES DE LUCHA CONTRA EL NARCOTRAFICO. BOLIVIA Y SU RELACION CON LA DEA.

Capitulo IV: NARCOTRAFICO EN ARGENTINA. FACTORES QUE PERMITEN SU AVANCE EN ARGENTINA. DIAGNOSTICO. CARTELES ACTUAN EN ARGENTINA. ARGENTINA ¿NUEVO PARAISO DEL NARCOTRAFICO?. POLITICAS ANTI DROGAS. INGRESO DE DROGA POR LA RUTA NACIONAL 34. NARCOTRAFICO GANA TERRITORIO EN ARGENTINA. EL PROBLEMA DEL NARCOTRAFICO EN ARGENTINA. MAPA ARGENTINO DE LOS NARCOS.

Capítulo V: APLICACIÓN Y ANALISIS DE LA MATRIS F.O.D.A. EN EL PROBLEMA DEL NARCOTRAFICO EN BOLIVIA Y ARGENTINA. ANALISIS F.O.D.A. DE ARGENTINA. SITUACION EXTERNA Y SITUACION INTERNA. ANALISIS F.O.D.A. DE BOLIVIA, SITUACION INTERNA Y SITUACION EXTERNA. CONCLUSIONES FINALES

La modalidad elegida para la realización del presente trabajo es "descriptiva" con la finalidad de profundizar conceptos de una forma clara y objetiva, detallando la situación que se vive en ambos países para luego tratar de establecer la relación de uno y otros con respecto al incremento de esta actividad criminal. 


\section{$\underline{\text { PROLOGO }}$}

El desarrollo y el producto resultante de la Inteligencia estratégica debe servir como herramienta para la toma de decisiones y punto de partida para generar estrategias de seguridad y de defensa para ser aplicadas sobre las distintas amenazas o nuevas amenazas que pudieran acechar a nuestro país, por lo cual se hará uso de esta ciencia multidisciplinaria para poder estudiar y analizar la función de Bolivia como nuevo epicentro del narcotráfico en Sudamérica, tratando de establecer a su vez si Argentina se ve perjudicada por esta situación.

El narcotráfico es una de las facetas que otorga mayores dividendos dentro del Crimen Organizado Transnacional, por tal motivo dicha actividad criminal está avanzando globalmente a pasos agigantados, dicho avance se está volviendo más vertiginoso en Sudamérica, este se debe a muchos factores, entre los cuales podemos enumerar el tema elegido en el desarrollo del presente trabajo de investigación.

Actualmente nuestro país está siendo desestabilizado por las repercusiones que genera el desenvolvimiento del narcotráfico dentro del territorio nacional, esta actividad anti sistémica constantemente se alimenta de distintos factores que se estudiaran.

El rol que está cumpliendo Bolivia dentro del engranaje del narcotráfico en Latinoamérica es de vital importancia para su crecimiento y expansión, generando que esta actividad criminal aumente su magnitud en otros países de la región entre los cuales nos encontramos nosotros (Argentina).

La producción de hoja de coca, la corrupción, la falta de control por parte de las autoridades estatales encargadas de tal función y el accionar de distintas bandas criminales tanto nacionales como de otros países dentro de Bolivia hacen que sea una oportunidad propicia para el avance del crimen organizado en ese territorio.

Todas estas variables serán descriptas, analizadas y estudiadas, para así de algún modo poder establecer si las mismas hacen que el narcotráfico aumente a gran escala en Bolivia y a su vez incida en el avance sobre nuestro país, en caso de comprobarse esta hipótesis brindaran una serie de recomendaciones con la finalidad de que el presente escrito sea de utilidad para los diferentes estamentos de toma de decisiones así como de guía para las fuerzas de seguridad y policiales. 


\section{INTRODUCCION}

\section{TEMA A INVESTIGAR:}

\section{"BOLIVIA COMO EPICENTRO DEL NARCOTRAFICO EN SUDAMERICA Y SU INCIDENCIA EN ARGENTINA"}

\section{DEFINICION DEL PROBLEMA}

El presente trabajo investigativo intenta abordar una problemática regional que va en constante ascenso y de geopolítica mundial, perjudicando la gobernabilidad de los estados como lo es el NARCOTRAFICO, este flagelo involucra a los países latinoamericanos, que comparten fuertes vínculos comerciales, teniendo como objetivo común combatirlo en post de su disminución y hasta erradicación, mediante la utilización de distintas medidas y/o estrategias de seguridad, la aplicación de legislación vigente, erradicación de zonas de cultivo de materia prima de cocina, cortar rutas que transportan droga, entre otras hechos que lo favorecen.

En la investigación se expondrán las dificultades y limitaciones que presentan los países integrantes del cono sur contra el avance de dicha actividad criminal; la zona de estudio es una región estratégicamente ubicada, propicia para el asentamiento del Crimen Organizado, el cual afecta directamente la gobernabilidad de algunas ciudades de fronteras y barrios de las capitales de países como Bolivia, Argentina, Brasil, Perú entre otros; y si no se cuenta con las herramientas y la planificación necesaria podríamos perder esta batalla.

Conocemos lo complejo de esta problemática y más aun sabiendo que Argentina se ha convertido en los últimos años en un país de tránsito donde también ha crecido el consumo, formando parte de una triangulación junto con Brasil y Bolivia, dando salida principalmente a la cocaína proveniente de Bolivia y Colombia, estos países tienen uno de los índices de mayor producción de hojas de coca del mundo. Otro detalle a tener en cuenta es el constante crecimiento que tiene esta actividad ilícita dentro de Bolivia, existiendo una gran cantidad de variables que deberemos estudiar para conocer a fondo si esta situación afecta la región y por sobre todo saber si nuestro país se ve directa o indirectamente afectado.

Varios de los estados que conforman el cono sur de América expresan que se no cuentan con el recurso humano suficiente ni capacitado, ni con las herramientas tecnológicas ni la logísticas Tesis de Maestría 
necesaria para hacer frente a un flagelo tan grande y cambiante como lo es el Narcotráfico, si bien en los últimos años esta tipología de crimen organizado fue duramente perseguido en Latinoamérica hasta el momento no se logra obtener los resultados que se deseados.

Uno de los objetivos que se buscan alcanzar desde hace muchos años es la disminución y/o erradicación de los cultivos de hojas de coca, la cual es una de las materias primas más importantes para la elaboración de cocaína (o alguno de sus derivados) de Bolivia, Perú y Colombia; donde esta actividad agrícola forma parte de una cultura milenaria, por ello decimos que la figura del ESTADO tiene que estar presente en todo momento, debiendo ser el principal instrumento de gobernabilidad y autoridad en la región, que nos permitan realizar acciones conjuntas tendientes a evitar el problema que tanto oprime las comunidades americanas y europeas.

Hemos decidido abordar dicha problemática con el fin de lograr un informe que nos permita discernir acerca de las políticas en materia de control y represión del Narcotráfico, para que a través de la gobernabilidad sostenida por la educación y la difusión de la cultura, podamos realizar una verdadera integración y capacitación; considerándose que a este tipo de delito es importante hacerle frente desde el nivel jurídico, cultural, estadual, social y cultural ${ }^{1}$

\section{JUSTIFICACION DEL PROBLEMA}

La finalidad que buscamos con la confección del presente trabajo investigativo es brindar algunas aproximaciones teóricas sobre el tema de la droga y su tráfico, para poder comprender este fenómeno y debatir sobre las implicancias que genera en la actualidad a nivel local, regional y mundial.

El narcotráfico presenta, como práctica social, ingredientes propios de actividades de alta modernidad cuya hiper-reflexividad le permite adecuar sus modalidades y generar aprendizajes que hacen por demás compleja a la actividad.

Como delito transnacionalizado hace porosas las facultades de los Estados-nación para su lucha y erradicación constituyendo una actividad propia de un mundo globalizado. La alta rentabilidad que posee como actividad económica retroalimenta su complejidad y reflexividad, teniendo

\footnotetext{
${ }^{1}$ Lic. German Sergio Martínez (2008) "IV CONGRESO DE RELACIONES INTERNACIONALES" - LA PLATA PCIA DE BS. AS. - ARGENTINA

Tesis de Maestría
} 
consecuencias y externalidades de alto impacto en las comunidades humanas que, de alguna manera, se encuentran "cruzadas" por este fenómeno.

La contracara del narcotráfico lo constituyen el flagelo de la drogodependencia, la cual debe ser abordada no sólo desde su faceta médico-psicológica sino también como un fenómeno social. Es así como estos fenómenos revisten su verdadera importancia y resaltan la necesidad de ser estudiados en su verdadera magnitud y consecuencias.

Dadas las características mencionadas muchas veces el narcotráfico atenta contra los propios cimientos del Estado-nación disputándole el monopolio legítimo de la violencia como sucede en México y como sucedió oportunamente en Colombia. Esto hace situar a la actividad íntimamente relacionada con las nuevas amenazas a la seguridad internacional. De esta manera, narcotráfico y conflicto armado se encuentran íntimamente relacionados ${ }^{2}$.

Al crimen organizado transnacional le gustan las oportunidades y la poca resistencia, actualmente Bolivia ofrece ambas y se encuentra en el corazón de una nueva dinámica criminal que amenaza la seguridad nacional y ciudadana en este país andino y ello directa o indirectamente afecta los países de la región.

Esta nueva dinámica criminal está centrada en los cambiantes patrones de consumo de drogas en la región. El papel dominante de México en el comercio regional de drogas se debe mucho a su ubicación, cerca del consumidor de drogas más grande del mundo, así como a su capacidad para producir drogas como heroína, marihuana y metanfetaminas. Bolivia está muy cerca del que es hoy el segundo mayor consumidor de drogas ilegales del mundo: Brasil. Bolivia también limita con el principal productor de cocaína del mundo, Perú, y con el principal productor de marihuana de Sudamérica, Paraguay. Mientras tanto, Argentina está experimentando un aumento en el consumo interno de drogas, en particular de "basuco" o "paco", un tipo de cocaína que se puede producir en Bolivia. En la actualidad, incluso los mercados domésticos de drogas de Chile y Perú están presentando un crecimiento.

Hoy en día Bolivia está literalmente en el corazón del comercio de narcóticos ilegales de Sudamérica, a esto hay que sumarle que Bolivia también produce su propia cocaína; por ello es un abanico de posibilidades para el asentamiento del crimen organizado transnacional.

\footnotetext{
${ }^{2}$ BULCAURF, Pablo y VAZQUEZ Juan Cruz "Narcotráfico: Dimensiones y Elementos para su análisis" - disponible en http://www.saap.org.ar/esp/docs-congresos/congresos-saap/VII/programa/paneles/e/e1/bulcourf-vazquez.pdf Tesis de Maestría
} 
Esta dinámica en Sudamérica es totalmente independiente de las tradicionales rutas de tráfico de drogas que alimentan el mercado de Estados Unidos, así se lo determino luego de haber consultado una de las paginas bases en la realización de la presente tesis InSight Crime ${ }^{3}$ quienes pudieron establecer luego de tomar conocimiento del resultado del análisis químico de las sustancias incautadas en territorio estadounidense que sólo el cinco por ciento de ella proviene de Bolivia.

Estas dinámicas en sí mismas podrían convertir a Bolivia en un epicentro del tráfico de drogas, pero también hay otros factores que hacen de este país un terreno bastante fértil para el Crimen Organizado Transnacional (COT).

Es importante señalar que Bolivia, con una tasa de homicidios de 11 por cada 100.000 habitantes, es un país seguro para los estándares latinoamericanos. El gobierno del presidente Evo Morales ha registrado un éxito significativo en la lucha contra el tráfico de drogas, principalmente en lo que respecta al control de los cultivos de coca. Sin embargo, los recursos que actualmente están siendo desplegados por el Estado boliviano para enfrentar al COT enfocados en los posibles beneficios económicos del comercio de la droga- han probado no ser suficientes ${ }^{4}$.

Desde hace unos años a la fecha somos testigos del avance arrollador de las actividades del narcotráfico sobre el territorio de nuestro país, este avance puede tratarse por diversas razones, una de ellas puede ser atribuida a la cercanía y límites fronterizos que poseemos con nuestro vecino país de Bolivia.

Aducimos esta cercanía como uno de los factores que ocasionan el aumento del narcotráfico en nuestro país debido a que Bolivia actualmente es considerada como el epicentro del narcotráfico en Sudamérica lo cual afecta nuestro territorio, Bolivia está inmersa en una situación bastante alarmante ya que a medida que pasa el tiempo las organizaciones criminales de carácter transnacional ven a este territorio muy atractivo para desarrollar sus actividades delictivas.

\footnotetext{
${ }^{3}$ http://es.insightcrime.org/quienes-somos

${ }^{4}$ INSIGCRIMEN (2014) "El desafío de Evo: Bolivia epicentro del narcotráfico" - MC DERMOTT, Jeferemy, disponible en https://www.dropbox.com/s/pov9l2ncjsprepa/bolivia_desafio_drogas.pdf?dl=0

Tesis de Maestría
} 
Existen una serie de factores que hacen que Bolivia presente vulnerabilidades en su área de seguridad evitando una efectiva lucha contra el narcotráfico como lo que actualmente es considerada uno de los tres países en el mundo que más produce hoja de coca, la cual es la materia prima del clorhidrato de cocaína, por este y otros temas es que el narcotráfico está avanzando.

Amen a lo enunciado otro de los factores que ayudan al incremento del narcotráfico es el escaso control que se efectúan sobre las áreas de cultivo de hojas de coca, si bien fue política de estado del gobierno del actual presidente EVO MORALES controlar estas áreas, esto no se está cumpliendo ya que año tras año la cantidad de hectáreas donde se cultiva hoja de coca es mayor.

El citado mandatario a su vez tuvo un altercado con miembros de gobierno de los Estados Unidos lo que ocasionó que las autoridades de la DEA abandone este territorio ${ }^{5}$, acotando que este organismo es la institución más idónea y especializada en lo que respecta al combate del narcotráfico en América y el mundo.

Esta enemistad que surgió entre Bolivia y Estados Unidos no solo ocasionó que la DEA abandone ese país, sino que a su vez Estados Unidos dejo de apoyar económicamente a Bolivia, es decir ya no efectuaba aportes económicos que ayuden a las investigaciones, capacitación de las fuerzas de seguridad e incremento de logística para combatir esta problemática.

En lo que respecta al área judicial o la existencia de leyes que ayuden al combate del narcotráfico en Bolivia también es muy escasa ya que este país no cuenta con herramientas judiciales que son de mucha utilidad en otros países, tales como no contar con una legislación que autorice en caso de ser necesario a la interceptación de comunicaciones, no existe un control del espacio aéreo careciendo de una efectiva ley de derribo entre otras falencias.

Continuando con la enumeración de los factores que consideramos ayudan al crecimiento del narcotráfico en Bolivia decimos que el hecho de tener una cercanía con el país donde mayor cantidad de hoja de coca se produce no le es favorable. Perú no solo es considerado por los organismos internacionales como el mayor productor de hojas de coca, sino que el narcotráfico también avanzo sobre su territorio, cuyas organizaciones criminales se desplazaron y trasladaron hacia Bolivia.

\footnotetext{
${ }^{5}$ http://www.noticias24.com/actualidad/noticia/19475/bolivia-acusa-a-la-dea-de-conspiracion-y-suspende-sus-operaciones/ Tesis de Maestría
} 
No obstante ello podemos decir que si no existiera demanda de una forma $u$ otra la oferta disminuiría, por lo cual no es beneficioso para Bolivia tener límite fronterizo con Brasil, el cual actualmente es considerado como el segundo país más consumidor de drogas ilícitas, por detrás de Estados Unidos, así mismo limita territorialmente con nuestro país, cuyo consumo de estupefacientes va en constante aumento.

A continuaciones en el detalles de factores que posibilitan este incremento ingresamos nosotros, Argentina, cuyo mercado de demanda de sustancias ilícitas se está incrementado de manera exponencial considerándose actualmente como el segundo mayor mercado en Sudamérica detrás de Brasil, debido a la cercanía territorial todo lo relacionado al tráfico ilícito de sustancias estupefacientes aumenta en volumen día a día, no solo el micro tráfico (consumo interno) macro tráfico (país como tránsito para la comercialización de drogas ilícitas a gran escala) ${ }^{6}$.

\section{FORMULACION DEL PROBLEMA:}

Durante los últimos años el Narcotráfico está avanzando a pasos agigantados en todo el mundo globalizado en el cual vivimos, Sudamérica no es la excepción más aun teniendo en cuenta que en este territorio se encuentran países productores de sustancias estupefacientes como lo son Colombia, Perú, Bolivia y Paraguay (marihuana); existe una conectividad en los países de la región siendo utilizados los mismos como rutas para traficar dichas sustancias acotándose además que el consumo de las mismas también está en constante crecimiento.

Bolivia primeramente era un país de tránsito de estas sustancias, luego se convirtió en un país productor y actualmente el consumo también se está incrementando, a ello debemos sumarle una serie de variables que hace este país se considerado como el nuevo epicentro del narcotráfico, lo cual afecta a la Argentina de una forma directa o indirecta.

\section{HIPOTESIS:}

"La producción de droga en Bolivia, su cercanía con otros países productores, la facilidad de las comunicaciones, la corrupción, la carencia de legislación adecuada y otras debilidades

\footnotetext{
${ }^{6}$ INSIGCRIMEN (2014) "El desafío de Evo: Bolivia epicentro del narcotráfico" - MC DERMOTT, Jeferemy, disponible en https://www.dropbox.com/s/pov912ncjsprepa/bolivia_desafio_drogas.pdf?dl=0

Tesis de Maestría
} 
propias del sistema político del vecino país lo convierten en el epicentro del narcotráficode Sudamérica, lo cual afecta a nuestro país”.

\section{V.I. OBJETIVO GENERAL:}

- Determinar si actualmente Bolivia puede ser considerada como el epicentro del narcotráfico en Sudamérica y como el aumento de esta actividad criminal en ese territorio influyo en el aumento del Narcotráfico en la Argentina.

\section{V.II. OBJETIVOS ESPECIFICOS}

- V.II.I Determinar cuál es la situación actual del Narcotráfico en la Republica Plurinacional de Bolivia.

- V.II.II Determinar cuál es la situación actual del Narcotráfico en la República Argentina.

- V.II.III Determinar si el aumento del Narcotráfico en Argentina se vio influido por la evolución de dicha actividad en Bolivia.

- V.II.IV Determinar fortalezas y capacidades de los actores involucrados en el narcotráfico en ambos países

- V.II.V Identificar vulnerabilidades y debilidades de los actores involucrados en el narcotráfico en ambos países

- V.II.VI Determinar fortalezas y capacidades de los actores legales (fuerzas de seguridad y de inteligencia) para combatir el narcotráfico.

- V.II.VII Identificar debilidades y vulnerabilidades de las fuerzas legales para combatir el narcotráfico.

\section{MARCO TEORICO DE REFERENCIA}

La realización del presente trabajo de investigación tiene su sustento o sus bases teóricas en los contenidos de las disciplinas: Inteligencia Estratégica, Planificaron Estratégica y Ciencias Políticas.

Es fundamental contar con la información necesaria y suficiente para poder elaborar medidas preventivas de seguridad en post de poder contrarrestar el avance del narcotráfico, para ello es de vital importancia la utilización de una de las disciplinas básicas en esta carrera como lo es la Tesis de Maestría 
Inteligencia Estratégica, ya que luego de recolectar, estudiar y analizar la información necesaria se podrán elaborar estrategias preventivas y represivas contra este flagelo mundial.

Cuando hablamos de "Inteligencia Estratégica" es inevitable hacer mención al Profesor Sherman Kent quien escribió una obra celebre denominada con este nombre INTELIGENCIA ESTRATÉGICA; siendo considerado y reconocido a través del paso de los años como "el padre" de esta disciplina, si bien Kent no hizo hincapié en la definición del término o terminología "Inteligencia" como actualmente la conocemos; el hizo alusión a esta palabra dividiéndola tres partes ${ }^{7}$ :

\section{$\left.1^{0}\right)$ "Información es Conocimiento" $2^{\circ}$ ) "Información es Organización" \\ 30) "Información es Actividad".}

En cambio podríamos decir que, su predecesor el General Washington Platt, fue quien verdaderamente desmenuzo y explico el verdadero significado de esta palabra como nosotros la interpretamos en nuestra carrera (Magister en Inteligencia Estratégica Siglo XXI), es decir que "Inteligencia" es el proceso al cual se somete una información dando como resultado un nuevo conocimiento más acabado de lo que estamos interesados, es decir es la ““información procesada" ${ }^{\prime}$.

Con el aporte de estos dos grandes autores la Inteligencia Estratégica comenzó a ser reconocida como una actividad, un conocimiento y como una organización importante, encargada de estudiar e interpretar la realidad a los fines de asesorar a quien debe tomar decisiones, en los diferentes niveles de conducción.

Para la interpretación de toda la información requerida y el análisis de la misma se hizo uso en gran parte de la I.E. como disciplina para poder abordar esta problemática con la seriedad que se merece y poder aportar su resultado a los más altos niveles de toma de decisiones, ya que en ellos esta poder implementar una $u$ otra sugerencia de medidas de seguridad sugerida, por ende para el tratamiento específico del problema cuyo estudio ha sido abarcado, se utilizó tanto de la doctrina y del marco legal vigente, como también de las publicaciones hechas por reconocidos especialistas y autores, todos los cuales figuran en la bibliografía cuyo listado se agrega al final.

\footnotetext{
${ }^{7}$ http://escuelasuperior.com.ar/instituto/wp-content/uploads/2017/05/InteligenciaEstrategica.pdf

${ }^{8}$ Gral. Washington Plattm (1983) "Inteligencia Estratégica" - Argentina: Struhart

Tesis de Maestría
} 


\section{CAPITULO I:}

Consideraciones y conceptos básicos: El Crimen Organizado como objeto de estudio

El principal objeto de estudio del presente trabajo investigativo es el NARCOTRAFICO el cual es una de las tipologías del Crimen Organizado, considerándose de importancia antes de comenzar con el desarrollo del trabajo hacer una distinción general (pero fundamental) de la diferencia existen entre Terrorismo y Crimen Organizado, ya que si bien ambos conceptos tienen similitudes son totalmente diferentes. Con esto no buscamos ahondar en la definición y demás características del Terrorismo pero debemos delimitar desde una perspectiva general sus fines, que en definitiva es lo que implica la existencia de autor y delito: la búsqueda, hallazgo y ejecución del interés previamente planificado.

El terrorismo aun teniendo una similitud organizacional con el crimen organizado en cuanto a su estructura y jerarquía, se diferencia principalmente en los fines que persigue, y en los daños a gran escala que produce. Sus miembros buscan financiamiento para subsistir y para proyectar sus acciones moviéndose por ideología y política, ocasionando daños irreparables como lo es la pérdida de vidas humanas; en cambio crimen organizado busca el beneficio económico como único fin, viven por y para el crimen como medio de subsistencia, causando en la víctima daños materiales, económicos y personales, éstos últimos de menor proporción, si tenemos en cuenta que las víctimas fallecidas como consecuencia de actos derivados del crimen organizado son menos cuantiosas?.

Habiendo expuesto las diferencias existente entre una y otra actividad criminal, nos centraremos en el crimen organizado, que constituye hoy día una amenaza presente y futura de difícil erradicación, Argentina, Bolivia y el resto de los países de la región son propicios para el asiento del crimen organizado, ello se debe principalmente a su situación geográfica, su capacidad de producir estupefacientes y de exportarlos. Argentina tiene salida al mar, además limita geográficamente con Bolivia, Paraguay (productores), Brasil (consumidor) entre otro países, es decir que las fronteras internas son muy permeables por lo cual un ciudadano residente en América Latina puede circular libremente por un gran número de países sin ser controlado a su entrada o salida, lo mismo ocurre con aquellos ciudadanos que no siendo parte del espacio logran introducirse en uno de esos países, consecuencia inmediata: escapan por tanto a un filtro

\footnotetext{
${ }^{9} \mathrm{https}: / /$ www.academia.edu/5623306/CRIMEN_ORGANIZADO Tesis de Maestría
} 
adecuado, luego nos encontramos ante una delincuencia globalizada, no sólo en cuanto a los distintos miembros que componen sus grupos, de diversa nacionalización, también en cuanto a su circulación, que implica el aumento y establecimiento del "crimen organizado foráneo" en territorio Sudamericano, sin olvidarnos por supuesto del "crimen organizado local" como los clanes familiares del narcotráfico en tanto en Argentina como en Bolivia; o el Crimen Organizado existente en Colombia y Brasil que a su vez exportan e importan su criminalidad, teniendo ramificaciones y vinculaciones con otros grupos que operan fuera de sus países de origen. A todo ello hay que sumar, la existencia de países productores de hojas de coca y por ende de cocaína como lo son Colombia, Perú y Bolivia; y la existencia de países en donde el consumo de sustancias estupefacientes va en crecimiento como Brasil y Argentina, generando esto el combo perfecto de oferta-demanda.

\section{Definición de Crimen Organizado:}

Antes de definir o dar un concepto de la terminología "crimen organizado", primeramente debemos hacer notar que su conjunto de palabras no constituye delito en sí mismo, o como tal, así no está reconocido, para conocerlo deberemos previamente caracterizarlo.

A diferencia de la delincuencia tradicional, habitual u ocasional, el C.O es una "empresa" jerarquizada que genera múltiples dividendos y réditos económicos, su finalidad es netamente económica (obtención de ganancias) y no sólo para el que ejerce el mayor cargo en la organización, cada escalón tiene en común respecto al anterior, el mismo móvil criminal, en sus distintas proporciones dinerarias, cada concepto aquí reflejado describe los condicionantes que identifican su razón de ser, esto es, gravedad, asociación, estructura y personalización.

Definición Académica: La propia acepción de crimen como delito grave adjetiviza a esta tipología criminal, la Real Academia Española como así lo define, se encuentra en concordancia con las políticas de seguridad de los estados, que consideran el crimen organizado como una delincuencia grave, por ello resulta prioritario, paliar sus actividades, sus consecuencias y por supuesto, su sustento económico.

Definición Legislativa: El legislador cataloga el crimen organizado como asociación ilícita: "Son punibles las asociaciones ilícitas, teniendo tal consideración las que tengan por objeto cometer algún delito o, después de constituidas, promuevan su comisión, así como las que 
tengan por objeto cometer o promover la comisión de faltas de forma organizada, coordinada y reiterada".

En analogía a lo anterior, la doctrina jurisprudencial ha establecido una serie de requisitos para poder imputar a las redes del crimen organizado el delito de asociación ilícita:

\section{Pluralidad de personas asociadas para llevar a cabo una determinada actividad.}

2. Existencia de organización más o menos compleja en función del tipo de actividad prevista.

3. Consistencia o permanencia en el sentido de que el acuerdo asociativo ha de ser duradero y no puramente transitorio.

4. El fin de la asociación ha de ser la comisión de delitos, lo que supone una cierta determinación de la ilícita actividad, debiendo tener en cuenta que dicho delito se consuma desde el momento en que se busca una finalidad ya inicialmente delictiva, ni puede tampoco considerarse la pluralidad de sujetos integrada en la asociación como un caso de codelincuencia o coparticipaciónen los delitos de posterior comisión.

Es de importancia hacer constar que el tipo penal de asociación ilícita, podría considerarse como el delito global de este tipo de grupos, bajo él se enmarcaría el delito principal (ej.: tráfico de drogas) y cuantos otros fueren secundarios o paralelos a éste: logísticos (ej.: elaboración y utilización documentación falsa), financieros (ej.: blanqueo del beneficio) u operativos (ej.: robo vehículos como instrumento del delito).

Generalmente, la investigación tratará de determinar la existencia del delito principal y en basé a él, se obtendrá el resto del entramado, ello nos certificará la presencia o no de un grupo organizado, con los requisitos jurisprudenciales para su catalogación como tal, imputándoles el delito de asociación ilícita. Cada miembro de la organización responderá ante la autoridad judicial por el delito de asociación y por los múltiples delitos que hayan cometido, como autor, como cómplice o como encubridor. Como hemos visto en esta definición legislativa, he centrado la doctrina jurisprudencial en torno al tipo penal citado.

Definición Policial: Una definición policialmente generalizada nos la da INTERPOL, que enuncia que para que se considere a una actividad como CO debe cumplir cuatro requisitos:

1. Que el grupo lo formen más de tres personas.

2. Que actúen durante largo tiempo. 
3. Que el delito que cometan sea grave.

4. Que obtenga beneficios, poder o influencia

Independientemente de los cuatro requisitos citados, INTERPOL considera que deben cumplir también al menos dos de los siguientes:

5. Que en el seno del grupo haya reparto de tareas.

6. Que tengan jerarquías y disciplina interna

7. Que sean internacionalmente activos.

8. Que usen la violencia o la intimidación.

9. Que monten estructuras empresariales para desarrollar o enmascarar sus actividades.

10. Que participen en el blanqueo de dinero.

11. Que sus actos se beneficien de la corrupción.

En total, INTERPOL caracteriza al crimen organizado bajo seis requisitos mínimos de los once enumerados, pero no es difícil encontrar en una organización criminal, una estructura que cumpla con ocho, diez o los once criterios citados.

Como hemos visto en las distintas definiciones, el crimen organizado es grave, es estructura, es jerarquía, es distribución de funciones, es continuidad......es......empresa y como tal, poseen medios, poseen especialización, poseen coordinación, poseen seguridad (generan corrupción para asegurarse la ejecución de sus acciones delictivas) y poseen un móvil suficientemente atractivo que motiva la conducta de cada miembro: el rápido enriquecimiento, que anula cualquier comportamiento ético del ser humano ${ }^{10}$.

Los estándares delictivos del crimen organizado, vienen establecidos por la especialización de las organizaciones criminales en determinados tipos penales, influenciados o condicionados primeramente, por el beneficio económico a obtener, por su propia estructura, por su tecnología o incluso por el tránsito de la materia prima objeto del delito o por el propio mercado del producto. Si tomamos como ejemplo el tráfico de drogas a gran escala, podemos asegurar que los múltiples beneficios que genera, requiere de una gran estructura jerárquica para llevarlo a cabo, ejerce entre origen y destino un tránsito supranacional, bien como país puente hacia Europa

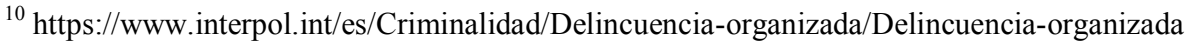
Tesis de Maestría
} 
(cocaína) o bien como país receptor (cocaína boliviana/marihuana paraguaya) refiriéndonos a Argentina.

Así como diferenciamos el $\mathrm{CO}$ del terrorismo haremos lo mismo diferenciándolo de la criminalidad común o delitos comunes, pero esta vez tan solo lo haremos mediante la ilustración de un cuadro comparativo para acotar conceptos:

Diferencia entre Crimen Organizado y Otro tipos de delitos ${ }^{11}$

\begin{tabular}{||l||l|l||}
\hline & $\begin{array}{l}\text { CRIMEN } \\
\text { ORGANIZADO }\end{array}$ & $\begin{array}{l}\text { OTROS TIPOS DE } \\
\text { DELITO }\end{array}$ \\
\hline \hline Transacción & $\begin{array}{l}\text { Producción y distribución } \\
\text { de nuevos bienes y } \\
\text { servicios }\end{array}$ & $\begin{array}{l}\text { Redistribución de la } \\
\text { riqueza existente }\end{array}$ \\
\hline \hline Relaciones & Intercambio multilateral & Transferencia bilateral \\
\hline \hline Intercambio & Consesual & Involuntario \\
\hline \hline Víctimas & ¿Sociedad? & Individuos o empresas \\
\hline \hline Moralidad & Ambigua & No ambigua \\
\hline \hline Política pública & $\begin{array}{l}\text { ¿Criminalizar la } \\
\text { asociación? } \\
\text { ¿Interceptar los activos? }\end{array}$ & Castigar al criminal \\
& Restaurar la propiedad \\
\hline
\end{tabular}

\section{$\underline{\text { El narcotráfico }}{ }^{12}$ como tipología delictual del crimen organizado}

La comercialización de sustancias estupefacientes es la faceta del crimen organizado que otorga mayores dividendos después del tráfico de armas, esta actividad criminal está en constante crecimiento a nivel mundial. Sin embargo, es de importancia hacer notar que si pensamos que al desbaratar una organización criminal dedicada a esta actividad ilícita o si interrumpimos el tránsito de una cantidad considerable de sustancias le estamos dando "un golpe al narcotráfico" estamos bastante alejados de la realidad ya que esta problemática muy compleja.

A veces nos confundimos con relacionar el narcotráfico únicamente con drogas ${ }^{13}$ ya que esta delito engloba y trae aparejado una actividad mucho complicado o actividad delictivas

\footnotetext{
${ }^{11}$ R. Thomas Naylor, "Mafias, myths, and markets: on the theory of enterprise crime", Transnational Organized Crime, vol. 3 , núm. 3 (Otoño de 1997), pág. 4

${ }^{12}$ NARCOTRÁFICO: es el comercio ilegal de drogas tóxicas en grandes cantidades. El proceso que comienza con el cultivo de las sustancias, sigue con la producción y finaliza con la distribución y venta suele ser realizado por diversos carteles que se especializan en cierta parte de la cadena ( ${ }^{12} \mathrm{http}: / /$ es.calameo.com/read/000903453c1552d2e9dab)
}

Tesis de Maestría 
relacionadas (lavado de dinero, por ejemplo). Bajo esta concepción los delitos de lo que denominamos "narcotráfico" son discriminados separadamente, se juzgan conductas individuales y no se construye una "historia" que permita ver un tipo específico de criminalidad que tiene al menos cuatro características principales ${ }^{14}$ :

1. Una organización es la que lleva a cabo esta actividad criminal, lo que en consecuencia hace que el narcotráfico cumpla con las leyes de la teoría organizacional. Las políticas de "descabezamiento" de las organizaciones criminales deben tener en cuenta este punto porque suelen convertirse en un proceso de rotación de liderazgos y no de desmantelamiento de la organización. Y por otro lado las organizaciones del narcotráfico se adaptan a rutinas organizacionales, las que deben ser detectadas y monitoreadas por los organismos policiales antes de intervenir.

2. Se efectiviza a partir de una conducta organizacional criminal y en consecuencia no se trata de "elecciones" o "decisiones" individuales aisladas; es algo en conjunto. El marco analítico de "rational choice" (teoría de la elección racional) es inadecuado para comprender la dinámica criminal en el narcotráfico, al cual se debe estudiar como un proceso que involucra dinámicas sociales, económicas y políticas.

3. Su finalidad y objetivo primordial es la obtención de ganancia económica, pero se desarrollan mediante instrumentos y en ámbitos no económicos, sino políticos. Por este motivo una guerra o un enfrentamiento abierto contra el narcotráfico potencia el comportamiento político de un actor que en circunstancias normales sólo se comporta como acumulador ilegal.

4. El fenómeno del narcotráfico es "invisible", no se constituye como tal hasta que las conductas individuales o particulares hayan sido involucradas en una totalidad ética y orgánica específica que da sentido y organicidad a las acciones celulares. Es imprescindible el seguimiento, cuantificación y diagnóstico de los delitos presuntamente "predatorios"15.

\footnotetext{
${ }^{13}$ DROGA: es una sustancia vegetal, mineral o animal que tiene efecto estimulante, alucinógeno, narcótico o deprimente. Se conoce como droga blanda a aquella que tiene un bajo grado adictivo, como el cannabis, mientras que una droga dura es fuertemente adictiva (como la cocaína y la heroína) http://es.calameo.com/read/00353134029a1fa16d290

${ }^{14} \mathrm{http}: / /$ www.ub.edu.ar/centros_de_estudio/ceprede/CEPREDE_02_03_2015.pdf

${ }^{15} \mathrm{http} / / /$ www.ub.edu.ar/centros_de_estudio/ceprede/CEPREDE_02_03_2015.pdf

Tesis de Maestría
} 
Estas características le otorgan al narcotráfico racionalidad y previsibilidad, típicas características organizacionales. Este carácter organizacional implica que el narcotráfico:

1. traer aparejado el lavado de dinero, tráfico de precursores químicos, producción, refinamiento, comercialización, militarización, información, inteligencia, logística, tecnología, organización y sistematicidad de la violencia, redes de abastecimiento, soborno, extorsión, secuestro, inversiones, etc.

2. incide en varios estamentos de la sociedad en general: fuerzas de seguridad, control territorial, crimen organizado, economía ilegal, reparto ilegal de la renta, acumulación primitiva de capital, fronteras, puertos y aeropuertos, exclusión social, maltrato y abuso infantil y adolescente, crímenes predatorios, fraude, evasión fiscal, etc.

3. abarca una amplia cadena de actividades, sectores sociales y geografías nacionales:

a. Actividades: cosecha de coca, raspado de la hoja, pisaderos, laboratorios, equipamiento, instrucción militar, transporte, bagayeo, tecnología, etc.

b. Sectores sociales: campesinado indígena, adolescentes marginales, graduados universitarios, migrantes, obreros desocupados, choferes, etc.

c. Geografías nacionales: el Putumayo colombiano, el Chapare boliviano y el Alto Huallaga peruano para la producción. Los puertos del norte colombiano, la línea norte (10 ciudades) de México, el puerto de Rosario y Buenos Aires y las fronteras lábiles en general (frontera norte argentina) para el tránsito externo. Los corredores mexicanos y colombianos de tránsito interno, etc.

4. El narcotráfico tiene capacidad para dar significado social a geografías inviables, o sea "crear" geografías: las triples fronteras son particularmente sensibles a este fenómeno: Mexicali, California y Arizona entre Estados Unidos y México. Leticia, Tabatinga, Santa Rosa entre Colombia, Brasil y Perú. En Leticia y Tabatinga, Colombia y Brasil están separadas por una calle que se cruza sin mostrar pasaporte

5. Sus constantes variantes permite que no todas sus actividades estén relacionadas con drogas. Es el caso del lavado de dinero y los precursores químicos, más una larga serie de "servicios" que el narcotráfico crea, organiza, dirige y utiliza (por ejemplo, los halcones, menores de edad 
que "vigilan" e informan a los jefes). Tacna es la parte peruana de una triple frontera entre Perú, Chile y Bolivia. Lo mismo sucede con los llamados "espacios vacíos" o "territorios sin ley", como el Petén mexicano, el Darién panameño o Salvador Mazza en el norte argentino.

Esa inmediata asociación que hacemos entre narcotráfico y drogas entiende que todo el proceso tiene como eje central y destino final el consumo de drogas aunque al mismo tiempo debate sobre la tipificación de ese consumo como hecho penal o como problema de salud pública, sin resolver si se trata de un delito o una enfermedad. Por ello decimos que el concepto de tráfico de drogas encierra tres contradicciones:

1. Debatimos sobre la legalidad del consumo, entendido como actividad de la esfera privada que no daña a terceros, mientras se continúa de hecho con su policiación y judicialización, percibido al mismo tiempo como eslabón de la cadena del tráfico y como un problema de salud pública

2. Se promueve que el consumidor pase de la esfera penal a la esfera civil mientras se sigue sosteniendo por definición que el tráfico de drogas es un problema de adicción, toxicomanía o consumo de estupefacientes, como si todo el circuito fuera esencialmente no punible. En este punto las drogas se comparan con el alcohol o el tabaco, que son de consumo legal y un problema de salud pública. Sin embargo y llamativamente las drogas no son legales y son un problema penal

Estas dos primeras contradicciones plantean un escenario donde el consumo privado es legal y un problema de salud pública no reprimible penalmente, mientras se propone aumentar las penas al tráfico de drogas. El consumo legal de una sustancia ilegal no hace más que aumentar la tendencia hacia el fortalecimiento de la red de abastecimiento, porque la mezcla de prohibicionismo y tolerancia puede debilitar la demanda, pero seguramente fortalece la oferta. Y los mercados económicos capitalistas sólidos se expanden por oferta, no por demanda

3. Se desconoce o subestima el hecho de que el consumo de drogas es el mercado "político" del narcotráfico. Aunque la aproximación liberal tipifica al consumo de drogas como una transacción establecida libremente entre un comprador voluntario y un vendedor de un bien ilegal, en realidad el consumo de drogas:

a. constituye un mercado, no una sumatoria de transacciones individuales libres. 
b. Se da en un territorio social y geográfico previamente configurado y controlado, no libre. En un gran porcentaje, sobre todo en los estratos sociales más bajos, quien consume se convierte en vasallo político de un señor.

c. El mercado de consumo establece leyes y valores que son ajenos, extraños, sustitutivos y a veces contradictorios con el todo social circundante inmediato, no con el mediato ya que no existen antecedentes de que el desafío haya llegado al Estado nacional.

d. Contrariamente a lo que se afirma el narcotráfico prefiere entornos estables y no violentos, dentro de los cuales establece y garantiza la existencia de áreas de estandarización del crimen, en acuerdo con las fuerzas policiales.

El narcotráfico no necesariamente tiene vinculación con las drogas. Aunque se trata de dos problemas muy vinculados, son diferentes. Las drogas son un problema de salud pública y el narcotráfico es un problema político. Para el problema de las drogas sólo se necesita una intervención en el sistema de salud, con recursos e inversiones estatales y una fuerte asistencia a consumidores y adictos.

Pero el abordaje del narcotráfico necesita comprender la doble naturaleza organizacional y política de esta modalidad específica del crimen organizado.

- Al igual que las organizaciones, los grupos de narcotráfico tienen estructuras burocráticas, sistemas de rotación de liderazgos, rutinas procedimentales y respuestas operativas estandarizadas. Imitan el comportamiento empresario.

- Y por otro lado su naturaleza política los vuelve territoriales, monopólicos, estables y coactivos. Imitan el comportamiento estatal.

La violencia no siempre está presente. Cuanto más político es el comportamiento del narcotráfico habrá menos violencia aparente, porque se logró estabilizar el control territorial. Y cuando el mercado está más disputado hay más crímenes predatorios.

Las políticas de militarización incrementan el comportamiento pre-político del narcotráfico, incentivando la lucha por el control territorial e ingresando en una escalada que transformará a los grupos dispersos en carteles, en virtud de la propia lógica política de la violencia. Y las 
políticas de gerenciamiento policial del delito suelen ser efectivas hasta un límite que en el caso argentino está siendo rebasado.

En nuestro país se necesitan dos acciones legislativas centrales: reemplazar la actual Ley de Estupefacientes 23.737, que criminaliza el consumo, por una ley de salud pública para consumidores de drogas. Y reemplazar el actual encuadramiento aduanero del narcotráfico (art. 866 del Código Aduanero) por una penalización expresa del narcotráfico como delito complejo específico, más cerca de la Convención de Palermo sobre la Delincuencia Organizada Transnacional que del art. 210 del Código Penal sobre asociación ilícita.

El narcotráfico en sí mismo no es considerado un delito porque es catalogado como tráfico de drogas y queda subsumido dentro de la categoría "problema de drogas", cuando en realidad se trata de organizaciones que sólo se vinculan con las drogas en los eslabones inferiores de la cadena organizacional. La visión que sostiene que el narcotráfico es una cuestión de tráfico de drogas impide visibilizar el problema.

Actividades tales como la producción, el tránsito, el consumo, los precursores químicos, el lavado de dinero, la corrupción, el sicariato y otras del universo "narcotráfico", exceden ampliamente el léxico del "problema de las drogas".

Que el narcotráfico no sólo se dedique a las drogas significa que cada vez más se relaciona con el resto de actividades que componen el crimen organizado. Esta vinculación del narcotráfico con el crimen organizado tiene tres características:

1. Los grupos narcos se dedican a una serie de diversas actividades. El analista Edgardo Buscaglia sostiene que el crimen organizado incluye 22 actividades delictivas. En casi todas ellas podemos encontrar involucrados a grupos de narcotráfico.

2. Los grupos del narcotráfico que se dedican a actividades de crimen organizado, las utilizan, dependiendo del nivel de desarrollo de la organización, para financiar su actividad central de tráfico de drogas. Entre las actividades del crimen organizado hay una jerarquía de interés y tasa de ganancia, como en cualquier inversión de capital. El nivel de cooptación acelerada del narcotráfico mexicano implica grandes gastos de inversión de los grandes carteles (Sinaloa, Los 
Zetas) en el sostenimiento de grupos más pequeños, algunos de los cuales ni siquiera se dedican al narcotráfico (el cartel de Tijuana, prácticamente paralizado).

3. El narcotráfico es la única actividad que por sus características tiene capacidad de convertirse en organizador de todo el crimen organizado. El control territorial, la economía de la violencia, el flujo de capital, la movilidad y la alta politicidad de su comportamiento, permiten al narcotráfico entrar y salir del crimen organizado sin afectar su núcleo original de acumulación. No parecen ser acertadas las afirmaciones de los especialistas que sostienen que la palabra carteles es inadecuada porque éstos se han convertido en parte del crimen organizado. Es a la inversa, la expansión a que obliga la guerra contra el narcotráfico deja a los carteles con una capacidad organizacional ociosa (lo que implica tanto recursos físicos como management ${ }^{16}$ ) que es utilizada para extender actividades.

Si las problemáticas de drogas y el narcotráfico son dos cosas distintas, a nivel municipal se puede trabajar en políticas de proximidad con los consumidores de drogas y detectar algunos indicadores de narcotráfico. El consumo de paco merece una consideración totalmente separada $^{17}$

\section{$\underline{\text { Reseña sobre la labor e importancia de Naciones Unidad en el contexto mundial }}$}

Existen una serie de instrumentos internacionales que legislan a nivel mundial todo lo relacionado al narcotráfico y las sustancias estupefacientes; los estados nación que forman parte de la Organización de Naciones Unidas $(\mathrm{ONU})^{18}$ y adhieren a esta legislación lo hacen con el carácter de vinculante, es decir que deben ratificar mediante legislaciones propias todo lo establecido a nivel internacional:

Naciones Unidas es una organización internacional que se encarga de los siguientes temas:

\footnotetext{
${ }^{16}$ Entendemos el término "management" como la administración o gestión de todas las actividades asignadas por la división de trabajo dentro de una organización (https://aprendiendoadministracion.com/que-es-el-management/)

${ }^{17} \mathrm{http} / / /$ www.ub.edu.ar/centros_de_estudio/ceprede/CEPREDE_02_03_2015.pdf

${ }^{18}$ La Organización de las Naciones Unidas (ONU) es una organización internacional formada por 192 países independientes.

Estos se reúnen libremente para trabajar juntos en favor de la paz y la seguridad de los pueblos, así como para luchar contra la pobreza y la injusticia en el mundo.

En 1941, durante la Segunda Guerra Mundial, los presidentes de Estados Unidos (Franklin D. Roosevelt) y de Gran Bretaña (Winston Churchill) se reunieron para crear una organización que ayudara a mantener la paz en el mundo. En 1945, se unió a estos mandatarios Joseph Stalin, entonces dirigente de la antigua Unión Soviética, hoy llamada Federación de Rusia.

A estos tres países se unieron otros y así, en 1945, quedó establecida la ONU gracias a que 51 países - incluida Polonia, cuyo gobierno se encontraba en el exilio - se pusieron de acuerdo para firmar la "Carta de las Naciones Unidas"

(http://www.cinu.org.mx/ninos/html/onu_n.htm)

Tesis de Maestría
} 
MANTENIMIENTO DE LA PAZ: Tras la devastación de la Segunda Guerra Mundial, las Naciones Unidas empezaron su labor en 1945, con una prioridad: mantener la paz y la seguridad internacionales. Con este objetivo, la Organización intenta prevenir los conflictos y poner de acuerdo a las partes implicadas. Lograr la paz exige crear no sólo las condiciones propicias para que esta anide, sino para que se mantenga. El Consejo de Seguridad es el máximo responsable de la paz y la seguridad internacionales. La Asamblea General y el Secretario General, junto con otras oficinas y órganos de la ONU, también desarrollan un papel importante en esta tarea.

DERECHOS HUMANOS: El término «derechos humanos» se menciona siete veces en la Carta fundacional de la ONU, por lo que su promoción y protección son objetivos fundamentales y principios rectores de la Organización. En 1948, la Declaración Universal de los Derechos Humanos los situó en el terreno del derecho internacional. Desde entonces, la Organización ha protegido diligentemente los derechos humanos mediante instrumentos legales y actividades en el terreno. La Declaración Universal de los Derechos Humanos (1948) fue el primer documento legal de protección de estos derechos. Junto con el Pacto Internacional de Derechos Civiles y Políticos y el Pacto Internacional de Derechos Económicos, Sociales y Culturales, los tres instrumentos forman la llamada Carta Internacional de los Derechos Humanos. Una serie de tratados internacionales y otros instrumentos adoptados desde 1945 han aumentado la legislación internacional de derechos humanos.

ASUNTOS HUMANITARIOS: Uno de los propósitos fundamentales de las Naciones Unidas, como se afirma en su Carta, es «realizar la cooperación internacional en la solución de problemas internacionales de carácter económico, social, cultural o humanitario». La primera vez que la ONU participó en una reconstrucción tras un conflicto fue en Europa tras la devastación de la Segunda Guerra Mundial. Ahora, la comunidad internacional confía a la Organización la coordinación de las operaciones de socorro frente a los desastres, naturales o provocados por el ser humano, en las zonas donde la capacidad de las autoridades locales no es suficiente para hacer frente a la situación.

DESARROLLO: Desde sus inicios en 1945, una de las principales prioridades de las Naciones Unidas ha sido «lograr la cooperación internacional en la solución de los problemas de carácter económico, social, cultural o humanitario y en el desarrollo y estímulo del respeto a los derechos humanos y las libertades fundamentales de todos, sin distinción por motivos de raza, sexo, idioma o religión». Mejorar el bienestar de las personas sigue siendo uno de sus principales 
objetivos. El concepto de desarrollo ha cambiado con los años y en la actualidad los países han acordado que el desarrollo sostenible, que fomenta la prosperidad y las oportunidades económicas, un mayor bienestar social y la protección del medio ambiente, es el mejor camino a seguir para mejorar la vida de la población. En septiembre de 2000 los dirigentes mundiales se comprometieron a alcanzar los ocho Objetivos de Desarrollo del Milenio en 2015. Estas metas contemplan reducir a la mitad la pobreza extrema, detener la propagación del VIH/SIDA y garantizar la educación primaria universal. Para alcanzarlas, el Secretario General ha impulsado diferentes iniciativas, como el Reto del Hambre Cero y Cada mujer, cada niño. Se han logrado importantes progresos en la consecución de estos objetivos pero aún queda mucho por hacer.

DERECHO INTERNACIONAL: La Carta de las Naciones Unidas, en su Preámbulo, marcó un objetivo: «crear condiciones bajo las cuales puedan mantenerse la justicia y el respeto a las obligaciones emanadas de los tratados y de otras fuentes del derecho internacional». Desde entonces, el desarrollo del derecho internacional y el respeto por el mismo han sido elementos claves del trabajo de la Organización. Este trabajo se lleva a cabo a través de cortes, tribunales, tratados multilaterales; así como a través del Consejo de Seguridad, que puede aprobar misiones de mantenimiento de la paz, imponer sanciones o, si lo considera necesario, autorizar el uso de la fuerza cuando exista una amenaza contra la paz y la seguridad internacionales. La Carta de las Naciones Unidas, considerada un tratado internacional, le otorga estos poderes. Como tal, es un instrumento de derecho internacional y es vinculante para los Estados Miembros de la ONU. La Carta de las Naciones Unidas recoge los principios de las relaciones internacionales, desde la igualdad soberana de los Estados, hasta la prohibición del uso de la fuerza en las relaciones internacionales ${ }^{19}$.

\section{Legislación Internacional:}

El tráfico de drogas es un comercio ilícito mundial que incluye el cultivo, la fabricación, la distribución y la venta de sustancias que están sujetas a leyes que prohíben las drogas. En la Declaración sobre el Estado de Derecho, los Estados Miembros reconocieron la importancia de fortalecer la cooperación internacional en la lucha contra el problema mundial de las drogas. La Asamblea General ha reconocido también que «pese a que los Estados, las organizaciones competentes, la sociedad civil y las organizaciones no gubernamentales siguen intensificando sus esfuerzos, el problema mundial de las drogas... socava la estabilidad socioeconómica y política

\footnotetext{
${ }^{19} \mathrm{http} / / /$ www.un.org/es/sections/what-we-do/index.html Tesis de Maestría
} 
y el desarrollo sostenible.» (Cooperación internacional contra el problema mundial de las drogas (resolución 66/183) 20 $^{20}$

La labor de las Naciones Unidas en la lucha contra el problema mundial de las drogas se basa en tres importantes tratados internacionales de fiscalización de drogas, la Convención sobre Estupefacientes de $1961^{21}$ (enmendada en 1972), el Convenio sobre Sustancias Sicotrópicas de $1971^{22}$, y la Convención de las Naciones Unidas contra el Tráfico Ilícito de Estupefacientes y Sustancias Sicotrópicas de $1988^{23}$. Los tres convenios atribuyen funciones importantes a la Comisión de Estupefacientes ${ }^{24}$ y a la Junta Internacional de Fiscalización de Estupefacientes ${ }^{25}$

Las Naciones Unidas, por conducto del Equipo de Tareas del Sistema de las Naciones Unidas sobre la Delincuencia Organizada Transnacional y el Tráfico de Drogas, abogan por reequilibrar la política internacional sobre las drogas, centrarse más en la salud pública, la prevención, el tratamiento y la atención, y las medidas económicas, sociales y culturales ${ }^{26}$

\section{Breve reseña y comentario sobre la legislación en relación al Narcotráfico en Argentina}

Actualmente la legislación sobre todo lo relacionado con el narcotráfico es un debate trascendente, pudiendo considerarse de esta manera por un lado, por cuanto el abuso de sustancias psicoactivas $^{27}$ y el narcotráfico son problemas que enfrentan la mayor parte de las sociedades contemporáneas ${ }^{28}$, por otro lado, por cuanto las políticas dominantes, fundadas en el llamado "prohibicionismo" y en estrategias de derecho penal máximo, se encuentran fuertemente cuestionadas, no sólo por su ineficacia sino por el sufrimiento que han ocasionado. Adicionalmente, porque este debate permite a su vez volver a reflexionar sobre un tema, que no por clásico deja de ser relevante, y es el relativo a la justificación de la penalización de un comportamiento en una sociedad democrática.

\footnotetext{
${ }^{20} \mathrm{http}: / /$ www.un.org/es/comun/docs/?symbol=A/RES/66/183

${ }^{21} \mathrm{http}: / / \mathrm{www}$.unodc.org/unodc/en/treaties/single-convention.html

${ }^{22} \mathrm{http}: / /$ www.unodc.org/unodc/en/treaties/psychotropics.html

${ }^{23} \mathrm{http} / / / \mathrm{www}$.unodc.org/unodc/en/treaties/illicit-trafficking.html

${ }^{24} \mathrm{http}$ ///www.unodc.org/unodc/commissions/CND/

${ }^{25} \mathrm{https}$ ://www.incb.org/

${ }^{26} \mathrm{https} / /$ www.un.org/ruleoflaw/es/thematic-areas/transnational-threats/drug-trafficking/

${ }^{27}$ Las sustancias psicoactivas pueden ser de origen natural o sintético y cuando se consumen por cualquier vía (oral-nasalintramuscular-intravenosa) tienen la capacidad de generar un efecto directo sobre el sistema nervioso central, ocasionando cambios específicos a sus funciones; que está compuesto por el cerebro y la médula espinal, de los organismos vivos. Estas sustancias son capaces de inhibir el dolor, modificar el estado anímico o alterar las percepciones (http://www.odc.gov.co/problematica-drogas/consumo-drogas/sustancias-psicoactivas)

${ }^{28}$ Cuando hablamos de sociedades contemporáneas o tiempos contemporáneos hacemos alusión a la actualidad en la que vivimos, al mundo tecnológicamente avanzado y globalizado en el cual vivimos (acotación propia)

Tesis de Maestría
} 
Una revisión más o menos exhaustiva tanto de los antecedentes como de las condiciones (discursivas, ideológicas y políticas), bajo las cuales se ha materializado la legislación argentina que regula penalmente los comportamientos relacionados con el consumo de drogas, aparece como una condición necesaria a hora de examinar los modelos de abordajes presentes en esta temática.

En nuestro país las drogas y sus consumidores están tipificados en una ley nacional Ley Nacional de Estupefacientes $\mathrm{N}^{\mathrm{o}} 23.737$, en dicho cuerpo legal rotulamos a estas personas como potenciales delincuentes y enfermos, la posibilidad de contextualizar el origen y desarrollo del marco regulatorio legal de los comportamientos y situaciones relacionadas con las drogas, su uso y consecuencias incorpora la posibilidad de una problematización desnaturalizante de la dimensión jurídica- política de las cuestiones relacionadas con el consumo de sustancias psicoactivas.

En el mismo sentido la revisión de los "vaivenes" judiciales que se han dado en los últimos treinta años, los cuales se han relejado en fallos emblemáticos, dando cuenta de las diferentes interpretaciones que la norma legal puede tener, sirve a modo de "mapa histórico" de un debate que excede lo jurídico entrando de lleno en ámbito de las prácticas atinentes a la salud mental y sus marcos normativos regulatorios.

\section{La Guerra contra las drogas. Antecedentes y orígenes:}

Muchos estudios sobre estos temas han llegado a la conclusión que uno de los antecedentes principales para tener un posicionamiento ideológicos - políticos acerca del consumo de sustancias psicoactivas, nacieron con los movimientos sociales que comienzan a desarrollarse en los Estados Unidos a fines del siglo XIX y principios del siglo XX.

Estas posturas ideológicas estaban consideradas en dos facetas: por un lado, una creciente condena moral, generalizada en la sociedad estadounidense, hacia el consumo de ciertas sustancias asociadas a poblaciones y sectores sociales marginados y discriminados por dicha sociedad, como los negros (Cocaína), los inmigrantes chinos (Opio) y mexicanos (Marihuana).

Por otro lado, el cuerpo de instituciones médicas y farmacéuticas de Estados Unidos intentan consolidarse como un monopolio en cuanto a la prescripción de sustancias psicoactivas y comienzan a condenar la auto-administración, rechazando la venta libre en farmacias. 
El origen de esos pensamientos fue la moral protestante vigente en los siglos XVIII y XIX en los Estados Unidos que hace de la abstinencia una obligación moral para todos los seres humanos, teniendo como objetivo proteger a los hombres de sus propios excesos; esto es, protegerlos de sí mismos. Posteriormente estos principios morales, aunque continúan vigentes, fueron reemplazándose poco a poco por fundamentos de orden sanitario y social que complementan y justician a aquellos.

Estas tendencias aunque de origen diverso (y hasta contradictorio) tributarán de manera común a la generación e instauración de políticas y legislaciones prohibicionistas, donde se combinarán complementariamente principios científicos-sanitaristas y severos preceptos morales, condenando social y jurídicamente el uso de ciertas sustancias psicoactivas.

Es un dato objetivo que los Estados Unidos detenta actualmente el liderazgo mundial de las guerras antidrogas desde 1909, y su legislación prohibicionista ha aportado el modelo de los acuerdos internacionales para el control de las drogas. Las políticas prohibicionistas estadounidenses han ido ganando terreno hasta convertirse a nivel mundial en el paradigma ${ }^{29}$ de "la guerra contra las drogas", asociada desde 1969 con las administraciones Nixon, Reagan y Bush padre e hijo. Los principios ordenadores de esta lógica estadounidense pueden resumirse así: se exige la rendición, y por ende desaparición incondicional de traficantes, vendedores, adictos y ocasionales consumidores hedonistas ${ }^{30}$.

Podríamos decir las políticas prohibicionistas estadounidenses han fracasado una y otra vez y continúan fracasando. A pesar de su falta de éxito, el Departamento Estadounidense Antidrogas (DEA) ha convencido a los gobiernos de todo el mundo de que posee una experiencia inigualable e insoslayable en la temática de drogas.

Todos los gobiernos de turno de los Estados Unidos siempre han presionado explícitamente, la mayoría de las veces o implícitamente, las menos, a los estados europeos para que adopten estas tácticas fallidas, y en el caso de los países del denominado tercer mundo las ha impuesto de

\footnotetext{
29 "Un paradigma es lo que los miembros de una comunidad científica comparten, y, recíprocamente, una comunidad científica consiste en hombres que comparten un paradigma" (http://www.redalyc.org/pdf/860/86005004.pdf)

${ }^{30}$ El hedonismo es una doctrina de la filosofía que considera al placer como la finalidad o el objetivo de la vida. Los hedonistas, por lo tanto, viven para disfrutar de los placeres, intentando evitar el dolor.

Se trata de un conjunto de teorías morales que destacan que, por lo general, todo lo que el hombre hace es un medio para conseguir otra cosa. El placer, en cambio, es lo único que se busca por sí mismo (https://definicion.de/hedonismo/)

Tesis de Maestría
} 
manera rígida junto con sus recetas económicas, compartiendo con estas últimas tanto su "fundamentalismo" como sus reiterados fracasos.

La iniciativa llevada a cabo por el gobierno de Estados Unidos desde la segunda mitad del siglo $\mathrm{XX}$, en otros países, con el objetivo de la persecución de la producción, comercio y consumo de estupefacientes, a los que se les atribuye el estatus de drogas prohibidas, en tanto que no son medicinales, se dio a llamar "Guerra contra las Drogas". Con un discurso bélico, se utiliza esta metáfora de la guerra para transmitir el objetivo del estado de combatir con fuerza a las drogas, eliminándolas totalmente a través de medidas fuertemente criminalizadoras, con un marco legal propio. El compromiso, asumido por la comunidad internacional bajo el lema de la "Guerra contra la droga", se tradujo en la expansión del régimen de prohibición y en el aumento del control e intervención de algunos estados en los mercados nacionales e internacionales de la droga.

Globalmente se ha asimilado esta terminología bélica por parte de los gobiernos con sus consecuentes acciones para intervenir frente a esta problemática, trajo aparejado, tanto a Estados Unidos como a los países que se sumaron a esta iniciativa, consecuencias que se sostienen en el tiempo. La principal consecuencia de la Guerra contra las drogas es que los gobiernos invirtieron una cantidad enorme de recursos económicos, políticos, asistenciales en un objetivo que nunca se alcanzó.

Con el negocio del narcotráfico los carteles ${ }^{31}$ (organización de narcotraficantes) han obtenidos grandes ganancias económicas, se estima que mundialmente se producen dividendos por cientos de miles de millones de dólares, cantidades similares a las de los mercados de cigarrillos y licores $^{32}$.

La ineficacia e irracionalidad de las iniciativas y acciones inspiradas en el marco ideológicopolítico de la Guerra contra la drogas han sido recurrentemente ejemplificadas con datos de la realidad. Como afirma Rafael Pardo (2010): "La demostración final de la escasa o nula efectividad de la militarización como receta para controlar las drogas es la experiencia de Afganistán, país totalmente militarizado, ocupado con más de setenta mil efectivos de fuerzas de

\footnotetext{
${ }^{31}$ Un cártel o cartel, pues ambas grafías son correctas, es una organización criminal. Se trata de un término que hace alusión a los grupos de delincuencia organizada en el contexto de América Latina. En otras partes del mundo es más común emplear la palabra mafia. (https://www.definicionabc.com/derecho/cartel-narcotrafico.php)

${ }^{32} \mathrm{Si}$ bien el cigarrillo y el alcohol son consideradas drogas, ya que producen en el cuerpo una dependencia física para quienes las consumen en exceso, su comercialización no está penada, sino más bien fue regulada, siendo estos mercados uno de los que más ganancias generan anualmente en el mundo (acotación propia)

Tesis de Maestría
} 
la Organización del Tratado del Atlántico Norte (OTAN). Antes de esa ocupación, en 2001, durante el gobierno Talibán la heroína producida por este país fue de 74 toneladas. En 2006, en el quinto año de la ocupación liderada por Estados Unidos, la producción de heroína fue de 6.100 toneladas. Y en 2008 producía 87\% de la heroína del mundo. En el país más militarizado del mundo, con fuerzas predominantemente estadounidenses, la explosión de producción de heroína ha sido incontrolada". La corrupción del institucional es otra de las consecuencias. Para proteger sus ganancias, los delincuentes combaten con la policía y corrompen a funcionarios alrededor del mundo. Algunos carteles se han hecho más poderosos que los gobiernos y estados que se oponen a ellos.

\section{Antecedentes a la Ley 23737.}

En Argentina durante el año 1930 se sanciona la Ley 11.331, la cual modificó el artículo 204 del Código Penal introduciendo el párrafo tercero donde se incrimina la posesión y tenencia de drogas "no justificadas en razón legítima". Este es, por así decirlo, el momento fundante de la legislación prohibicionista en nuestro país. Como vemos, se inaugura con ella un fenómeno que alcanza a nuestros días. La ambigüedad y/o falta de precisión de expresiones tales como “justificadas en razón legítima” van a ser casi una constante en los discursos y textos en relación a las drogas y sus usuarios.

Es precisamente, la "Ley seca" norteamericana quizás el ejemplo más claro de las contradicciones y efectos de la lógica prohibicionistas. Durante la vigencia de esta ley la persistencia de la demanda y consumo de bebidas alcohólicas estimuló la fabricación y venta de licores, que se convirtió en una importante industria clandestina; la ilegalidad de esta práctica causó que el alcohol así producido adquiera precios elevadísimos en el mercado negro, atrayendo a éste a importantes bandas de delincuentes conocidas como "mafias".

El segundo antecedente legislativo en nuestro país data del 1942. El proyecto del diputado José Peco, es un proyecto legislativo que solo reprime la tenencia de sustancias cuando estén “destinadas al comercio o para suministrárselas a otros". Excluyendo de la punición la tenencia de una dosis para uso personal. Este proyecto no fue aprobado, pero denota ya en esos años el debate existente en relación a la persecución penal de las prácticas privadas, poniendo en cuestión que la mera tenencia de drogas pueda ser tratada como un hecho delictivo. 
Más adelante, en 1968 la Ley 17.567 que deroga la reforma del Código Penal (Ley 11.331), introduce un párrafo en el artículo 204: definiendo que sólo serán penalizados aquellos ciudadanos que posean cantidades que excedan las que correspondiera a un "uso personal". Esta ley vinculaba la tenencia en dosis mínimas que correspondieran al mero consumo individual con las acciones de la esfera de la libertad consagrada en el artículo 19 de la Constitución Nacional: "Las acciones privadas de los hombres que de ningún modo ofendan al orden y a la moral pública, ni perjudiquen a un tercero, están sólo reservadas a Dios, y exentas de la autoridad de los magistrados. Ningún habitante de la Nación será obligado a hacer lo que no manda la ley, ni privado de lo que ella no prohíbe" ${ }^{33}$.

Es importante señalar que esta reforma penal se da en el marco de un gobierno dictatorial encabezado por el General Juan Carlos Onganía. Por lo tanto, la historia nos depara el hecho paradójico que durante el transcurso de una dictadura militar que cercenó las garantías constitucionales, intervino violentamente las universidades nacionales, persiguió y encarceló a opositores políticos, etc., la tenencia de drogas para consumo personal se encontraba exenta de la autoridad de los magistrados y por lo tanto no era una conducta penalizada.

Las razones de esta paradoja pueden atribuirse a la injerencia del jurista Sebastián Soler en la redacción de dicha reforma. Sebastián Soler ya cuando fue Procurador General de la Nación en la década del 1950, se lo recuerda, entre otras cosas, por haber eliminado el Reglamento de Procedimientos Contravencionales, lo que hoy se conoce como Código de Faltas. Su argumentación era que este reglamento otorgaba una autonomía a la policía frente al Poder Judicial, ya que facultaba al Jefe de la Policía a constituirse en Juez de Primera Instancia, a sumariar y a condenar sin la intervención de la justicia ordinaria.

Finalizada la dictadura del General Onganía y con el regreso del gobierno constitucional de Héctor José Cámpora, primero, y el general Perón después, en 1973, la reforma del Código Penal del 1968, fue declarada ineficaz por la Ley 20.509, a partir de la cual se restaura el régimen de la legislación anterior.

Como se había mencionado en un apartado anterior la evolución de la legislación prohibicionista norteamericana, sobre todo a partir la década de 1970 va ir marcando y delimitando a la legislaciones de los países dependientes, entre ellos Argentina. Así, la guerra contra las drogas

\footnotetext{
${ }^{33} \mathrm{https}$ ///bibliotecadigital.csjn.gov.ar/Constitucion-de-la-Nacion-Argentina-Publicacion-del-Bicent.pdf Tesis de Maestría
} 
norteamericana tiene su correlato en la legislación penal de nuestro país. Es evidente que en la década de 1970 la influencia de las resoluciones de los organismos internacionales en cuanto a la legislación y políticas locales respecto del problema de las drogas, se llevó a cabo en el marco de la denominada "Doctrina de seguridad nacional" propia de la guerra fría cuyo axioma fundamental señalaba que "Los propios ciudadanos de un país son posibles amenazas a la Seguridad".

Bajo este contexto se desarrollan políticas en relación al consumo de drogas caracterizadas por un fuerte sesgo estigmatizador plasmadas en la sanción de la ley 20.771, en 1974, que penaliza la tenencia para uso personal. El proyecto de la citada norma nació en el Ministerio de Bienestar Social de la Nación que estaba por aquellos días a cargo de José López Rega, quién fue fundador de la Alianza Anticomunista Argentina (Triple A), el grupo parapolicial antecedente y precursor del Terrorismo de Estado en nuestro país.

Es importante señalar que la fundamentación del Poder Ejecutivo mediante la cual se elevó el proyecto de ley, expresó en forma muy clara respecto cuál era la naturaleza del bien jurídico a tutelar en la citada norma. En dos párrafos se evidencia la política del gobierno constitucional, luego hecha propia por la dictadura militar, a partir de marzo del 1976, de vincular "droga" con “subversión”.

La exposición de motivos de la ley 20771 incorporada al código penal de 1974 señalaba de manera inequívoca que, el control penal de las drogas era necesario para tutelar la "seguridad nacional" y la "defensa nacional": "el tráfico ilegal de estupefacientes debe ser perseguido hasta su aniquilación”. El artículo 6 de la ley 20.771 imponía la pena de 1 a 6 años de prisión al que "tuviere en su poder estupefacientes aunque estuvieren destinados a "consumo personal" y agregó al artículo 77 del Código Penal la definición “estupefacientes” que comprendía a los estupefacientes, psicotrópicos y demás sustancias "capaces de producir dependencia física o psíquica, que se incluyan en las listas que elabore la autoridad sanitaria nacional”.

Como mencionamos al principio de este apartado la ambigüedad y/o imprecisión terminológica signa la legislación sobre drogas. Tal es el caso, en la ley 20.771, de las expresiones “estupefacientes, psicotrópicos y demás sustancias "capaces de producir dependencia física o psíquica" que al no ser definida claramente deben remitirse a una lista elaborada por la 
"autoridad sanitaria", sin que se establezca criterio demarcatorio alguno para elaboración de dicha lista.

La vigencia de la ley 20.771 atravesó sin mayores inconvenientes los gobiernos: el de María Estela Martínez de Perón, las cuatro presidencias de la dictadura militar y el de Raúl Alfonsín.

\section{Ley 23.737}

Argentina está vinculada a la obligación internacional de sancionar el tráfico de estupefacientes prohibidos por la red de Tratados Internacionales. Existe una distribución internacional del control social y nosotros ocupamos una posición de un país de poco consumo en cuanto a los volúmenes internacionales de este tráfico. Es país de paso, de lavado y de inversión de capitales lavados (Zaffaroni, 1994).

En Argentina, dentro del marco de "La Guerra contra las Drogas", se encuentra vigente la Ley 23.737 sobre TENENCIA Y TRÁFICO DE ESTUPEFACIENTES, sancionada en 1989. La actual ley de estupefacientes modificó y derogó parcialmente a la ley 20.771. La ley de Estupefacientes, actualmente en vigencia, surge a partir de un proyecto del Diputado radical Lorenzo Cortese, siendo sancionada el 21 de octubre de 1989 y estableciendo un régimen legal sobre estupefacientes. Tipifica entre otras conductas penalizables, la tenencia simple, la tenencia para consumo personal y la tenencia con fines de comercialización, las cuales castiga con un sistema mixto que incluye la aplicación de penas y medidas de seguridad.

La ley 23.737 prevé medidas de seguridad curativas y educativas como alternativa a la pena privativa de la libertad para quienes se consideren usuarios de drogas. En su articulado se combinan y complementan estrategias punitivas como la cárcel, con medidas terapéuticas y tratamientos de diversa índole.

Algunos autores, desde una mirada crítica, han señalado que la ley 23.737, por la vía del tratamiento compulsivo, instaura una detención del consumidor por tiempo indeterminado, bajo control judicial, pero de acuerdo con recomendaciones de peritos (médicos, psiquiatras, psicólogos, asistentes sociales, etc.). De manera que la ley impone al profesional de la salud mental a cumplir funciones no sólo de orden sanitario, sino también -y esto es remarcado como muy alarmante- de agente de control social. 
En la misma dirección crítica y tomando algunas de las estadísticas policiales de nuestro país, se señala, por ejemplo, que la infracción a la Ley de Estupefacientes 23.737 se ha convertido en la primera causa de arresto entre las mujeres en nuestro país; de acuerdo a Rossi (2001) este fenómeno ha alcanzado en 1998 a más del 51\% de las mujeres detenidas.

A partir de estos datos se afirma que cuando un hecho ilícito se eleva como causa principal de las condenas y, al mismo tiempo, crece su incidencia en lugar de disminuir con la prohibición y la represión, cabe pensar que la legislación y sus procedimientos encubren procesos de control social condicionados por la moral vigente.

La definición de estupefacientes del Código Penal Argentino en el título 13 "Significaciones de conceptos empleados en el Código" comprende los estupefacientes, psicotrópicos y demás sustancias capaces de producir dependencia física o psíquica que se incluyan en la lista que elabora la autoridad sanitaria nacional. Manteniendo la ambigüedad que señalábamos en el apartado anterior para la ley 20.771 .

Entendemos por "Bien Jurídico" (...) aquel bien que el derecho ampara o protege. Su carácter deviene de la creación de una norma jurídica que prescribe una sanción para toda conducta que pueda lesionar dicho bien. Sin la existencia de esta norma, que tiene que estar vigente y ser eficaz, el bien pierde su carácter jurídico.

"En lo jurídico siempre es importante determinar cuál es el bien jurídicamente tutelado y en el caso de que hubiere más de uno establecer el orden de preeminencia. En el caso de la Ley 23.737, el bien jurídico es la "Salud Pública", a lo cual luego se le agregará el bien jurídico "Seguridad Pública". Por esto, los aspectos legales de las drogas (tenencia, consumo, distribución, suministro, tráfico) fueron vinculados alternativamente con la salud pública, la vida, la libertad, la intimidad, la defensa nacional y la defensa de la familia ${ }^{34}$.

\section{Postura de Bolivia ante la legislación internacional y legislación interna vigente:}

\footnotetext{
${ }^{34}$ Gómez, Raúl Angel (2013). LA LEGISLACIÓN PENAL ARGENTINA SOBRE DROGAS. UNA APROXIMACIÓN HISTÓRICA. V Congreso Internacional de Investigación y Práctica Profesional en Psicología XX Jornadas de Investigación Noveno Encuentro de Investigadores en Psicología del MERCOSUR. Facultad de Psicología - Universidad de Buenos Aires, Buenos Aires 
Finalizada la primera guerra mundial (1914-1918) la humanidad tomó conciencia de la necesidad de conseguir la unidad en temas de conveniencia general de los pueblos. Naciones Unidas resultó, con el paso de los años, la organización más ajustada para concretar anhelos de unidad e integración en cuestiones de seguridad, de evitar tentaciones para nuevas confrontaciones y, sobre todo, para convenir acuerdos en contra de la criminalidad en todas sus formas.

La lucha contra las drogas es, con seguridad, uno de los mayores acuerdos; es, con ese motivo, que se firmó en 1961 el Tratado de Naciones Unidas contra el narcotráfico. La disposición fue ratificada plenamente el año 1988 en Viena y, simultáneamente, en Bolivia se aprobó la Ley 1008 para combatir no sólo al narcotráfico sino sus mismas raíces como ser el cultivo excedentario de hojas de coca, su industrialización hasta el extremo de convertirse en cocaína cristalizada, su comercialización y, por supuesto, su consumo.

Muchas veces, parlamentarios de todos los partidos políticos y con representación legislativa, sugirieron, desde el mismo día de aprobación de la 1008 "la necesidad de modificarla" por considerársela muy dura contra los derechos humanos; sin embargo, ni senadores ni diputados oficialistas o de los diversos partidos políticos se han preocupado por sugerir las enmiendas del caso. Pasaron muchos años y la Ley 1008 sigue vigente porque ningún partido y ningún gobierno se animaron a introducir las "reformas" a los artículos calificados como "inconvenientes". Esa ley ratifica plenamente los tratados de Naciones Unidas.

El gobierno boliviano, aunque consciente de que el país es signatario de esos convenios o tratados, ha decidido, hace muy pocas semanas, denunciar tanto el Tratado de $1961^{35}$ como su ratificación de 1988. Una medida totalmente contraproducente y que podría ocasionar serios perjuicios al país, pese a todo lo que sostengan las autoridades que defienden su posición de ser "libres e independientes" para denunciar tratados o negarse a cumplir convenios internacionales.

\footnotetext{
${ }^{35}$ El Gobierno decidió denunciar la Convención de la ONU sobre Estupefacientes firmada en Viena en 1961, como protesta porque ese organismo no despenalizó el masticado de la hoja de coca. La Cámara de Diputados, de mayoría oficialista, aprobó el 22/06/11 en detalle y en grande el proyecto de ley que avala esa decisión del Ejecutivo, texto que pasó para su tratamiento a la Cámara de Senadores. El proyecto de Ley $\mathrm{N}^{\circ} 392$, de un solo artículo, fue aprobado luego de que se diera lectura a una carta del presidente Evo Morales y de escuchar la argumentación de esa decisión por parte del canciller David Choquehuanca.

La Convención de Viena de las Naciones Unidas sobre Estupefacientes, suscrita el 18 de abril de 1961, entró en vigor en abril de 1964 y fue enmendada por el protocolo de 1972. Bolivia reconoció en 1973 esta Convención, que establece un plazo de 25 años para eliminar la masticación de la coca. Además, tipifica a la hoja como estupefaciente. "La Convención de 1961 prohíbe el akulliku (masticado de coca). Si nosotros no hacemos esta denuncia, nuestros hermanos no van a poder ejercer esta práctica ancestral", sostuvo el canciller durante la sesión de Diputados. (http://www.encod.org/info/BOLIVIA-DENUNCIA-LACONVENCION.html)

Tesis de Maestría
} 
La verdad es clara: Ningún país puede denunciar tratados que impliquen compromisos para combatir la criminalidad, el asesinato en masa, los atentados contra los derechos y la vida de las personas, delincuencia que atenta contra el bien común y busquen, además, el reinado de las drogas ilícitas. Denunciar los tratados mencionados no es otra cosa que dar vía libre al incremento de los cultivos de coca, su industrialización y su comercialización como droga. Es, en buenas cuentas, colocar al país en situación interdicta en lo internacional porque nos muestra, como país y conjunto de seres humanos, partidarios del negocio ilícito como son las drogas alucinógenas.

Esta posición es igual a la que implicaría apoyar el crimen en todas sus formas porque es bien sabido en la conciencia internacional, que el letal negocio de las drogas encierra en sí mismo, lo ampara, lo protege y disemina todos los hechos criminales que asolan a la humanidad. Por supuesto, los grandes aliados del narcotráfico como son los armamentistas, seguramente apoyan las denuncias de Tratados a los que el país nunca debió renunciar. Lo que sobrevenga - como medidas punitivas contra el país - podría tener graves consecuencias a más del daño moral que se infiere a todo el país como Estado ${ }^{36}$

La legislación vigente en el Estado Plurinacional de Bolivia regula la conducta humana entre los ciudadanos, su relación con el Estado y sus instituciones, en el marco del respeto de los derechos fundamentales consagrados en la Nueva Constitución Política del Estado.

Una de las principales tareas del Estado Plurinacional, es la lucha contra el narcotráfico y delitos conexos, ya que el narcotráfico es un delito de lesa humanidad. La normativa legal vigente es un instrumento fundamental en la lucha contra el narcotráfico, que permite el accionar en el marco del respeto de los Derechos Humanos, el Estado Social de Derecho y los convenios internacionales; con estricto apego a la Constitución Política del Estado, el Código Penal y el Código de Procedimiento Penal. Se encuentra vigente la Ley 1008 "Ley del Régimen de la Coca y Sustancias Controladas" que define y limita las tres zonas productoras de hoja de coca en el país: la zona tradicional, la zona excedentaria en transición y la zona ilícita.

En el caso de la milenaria y ancestral hoja de coca, por primera vez en la historia, se incluye en la Nueva Constitución Política del Estado un artículo referido a la protección que se le otorga como patrimonio cultural y recurso natural renovable.

\footnotetext{
${ }^{36} \mathrm{http}: / /$ lapatriaenlinea.com/?nota $=75169$

Tesis de Maestría
} 
Sin embargo, a consecuencia de la inclusión de la hoja de coca en la Lista I de Estupefacientes de la Convención Única de Naciones Unidas de 1961, se ha planteado eliminar la prohibición del masticado de hoja de coca (akulliku) en Bolivia. La práctica cultural del akulliku se encuentra protegida por los principios y garantías constitucionales, por los derechos fundamentales de las personas, en conformidad a la Declaración de los Derechos de los Pueblos Indígenas y la Declaración Universal de los Derechos Humanos.

Estudios realizados por la Universidad de Harvard en 1975 y la Organización Mundial de la Salud (OMS) en 1995, demuestran que la hoja de coca no ocasiona daño alguno a la salud humana, del mismo modo los estudios nacionales y de los países vecinos, basados en evidencias culturales, antropológicas y científicas, demuestran que el consumo de la hoja de coca y sus productos derivados benefician a la salud humana.

Para la revalorización y dignificación de la hoja de coca y su industrialización, corresponde propiciar el cambio del status jurídico en las convenciones internacionales a partir de la revisión de la Ley 1008 y la reforma integral del marco legal existente, misma que se traducirá en dos cuerpos legales: la Ley General de la Coca y la Ley General de Sustancias Controladas, además de promover otras normativas complementarias que sirvan de instrumentos legales eficaces que permitan la lucha contra el narcotráfico.

La Ley General de la Coca promoverá el desarrollo integral de la hoja de coca, regulará la producción, comercialización y trasformación productiva de la coca, a través del control social e interdicción; y evitará su desvío para usos ilícitos.

La Ley General de Sustancias Controladas regulará y sancionará los delitos de tráfico de drogas, legitimación de ganancias ilícitas y delitos conexos a través de un proceso judicial ágil, transparente, operativo y eficiente que permita una gestión y administración judicial que garantice la implementación de las políticas públicas de la lucha contra el narcotráfico.

\section{Marco Institucional actual:}


Con la aprobación del Decreto Supremo (D.S.) 0649 de 29 de septiembre de 2010, se reestructura el Consejo Nacional de Lucha Contra el Tráfico Ilícito de Drogas $\left(\right.$ CONALTID $\left.^{37}\right)$, la presidencia alterna de este Consejo pasa a depender del Ministerio de Gobierno, estableciéndose una Secretaría Técnica y una Secretaría de Coordinación.

Asimismo, se crea el Consejo Nacional De Revalorización, Producción, Comercialización e Industrialización de la Hoja Coca $\left(\mathrm{CONCOCA}^{38}\right)$ bajo la presidencia del Ministerio de Desarrollo Rural y Tierras, cuyo objetivo es promover la revalorización de la hoja de coca y complementar el desarrollo integral en las zonas productoras para la transformación de la matriz productiva $^{39}$

\section{BOLIVIA}

Ley № 1.008. Ley del Régimen de la Coca y Sustancias Controladas.

Sancionada: 13 julio 1988. Promulgada: 19 julio 1988.

(Dirección General de Sustancias Controladas - http://www.dgsc.gob.bo/).

Decreto Supremo $\mathbf{N}^{\circ} \mathbf{2 2 . 0 9 9}, 28$ diciembre 1988. Reglamento a la Ley 1008. Sobre Régimen de las Coca y Sustancias Controladas.

(Dirección General de Sustancias Controladas - http://www.dgsc.gob.bo/).

Decreto Supremo № 24.963, 20 de Febrero de 1998. Estrategia Boliviana de Lucha Contra el Narcotráfico.

(Dirección General de Sustancias Controladas - http://www.dgsc.gob.bo/).

Ley № 521. Ley de Seguridad y Defensa del Espacio Aéreo.

Sancionada: 8 abril 2014. Promulgada: 22 de abril de 2014.

(Gaceta Oficial del Estado Plurinacional de Bolivia - http://www.gacetadebolivia.gob.bo/).

Consejo Nacional de Lucha contra el Tráfico llícito de Drogas (CONALTID). "Estrategia de Lucha contra el Narcotráfico y reducción de cultivos excedentarios de coca 2011-2015". 2011.

(Ministerio de Relaciones Exteriores - http://www.cancilleria.gob.bo/).

Reseña sobre la legislación vigente al año 2015 sobre Narcotráfico en Bolivia ${ }^{40}$

\section{La hoja de coca en Bolivia:}

\footnotetext{
${ }^{37}$ El Consejo Nacional de Lucha Contra el Tráfico Ilícito de Drogas (CONALTID) es el máximo organismo para la definición y ejecución de las políticas de lucha contra el tráfico ilícito de drogas y sustancias controladas http://conaltid.gob.bo/institucion/conaltid

${ }^{38}$ Decreto Supremo No 649 - Establece la estructura del Consejo Nacional de Revalorización, Producción, Comercialización y Industrialización de la Hoja de Coca

${ }^{39} \mathrm{http} / /$ www.cancilleria.gob.bo/webmre/sites/default/files/libros/13\%20estrategia $\% 201$ ucha $\% 20$ contra $\% 20 \mathrm{el} \% 20$ narcotrafico.

pdf
${ }_{40}$ http://www.pensamientopenal.com.ar/system/files/2016/07/doctrina43787.pdf

Tesis de Maestría
} 
Teniendo en cuenta que uno de los detalles más importantes a tener en cuenta al momento de referirnos al narcotráfico en Bolivia es el cultivo de la Hoja de Coca en este país, ya que esta plantación es considerada una tradición cultural en el lugar, por lo cual considero que se debe hacer una breve reseña sobre las consideraciones mínimas conceptuales de este arbusto:

La Erythroxylum coca ${ }^{41}$ es una arbusto que puede crecer solamente en suelos ácidos y a una altura de entre 300 y 2000 metros. Casualidad o destino, la biodiversidad andina, y más concretamente la de Bolivia, Colombia y Perú, reúne las condiciones óptimas para el cultivo de esta planta desde el siglo V. La civilización Tiwanaku (siglos V y XI), conocida por la herencia religiosa y agrícola legada al pueblo inca [Boero Rojo] dejó tras de sí algunos vestigios: las estatuillas de la región de Tiwanaku, que demuestran la importancia de la coca tanto por su dimensión simbólica sagrada como por su uso como remedio medicinal.

La masticación de la bola de coca, el acullico, es un modo de consumo particular y tradicional de la hoja de coca cuyos orígenes se remontan a los indígenas andinos y cuya práctica perdura en el pueblo boliviano. Bajo las civilizaciones precolombinas se utilizaba, y todavía se la utiliza, para disminuir los efectos de la fatiga, de la indigestión y también del apunado (mal de altura). Además, tiene un papel sagrado en los rituales de los pueblos andinos. Sin embargo, durante la colonización se dio un "boom" sin precedentes de esta práctica: la coca viajó hasta Europa y en 1855, un siglo después de su descubrimiento, el alemán Friedrich Gaedcke aisló la molécula de cocaína de la hoja de coca. Cinco años después, Albert Nieman elaboró por primera vez la cocaína bajo la forma de droga que se usa en nuestros días para el narcotráfico. Si bien es cierto que la coca sirve para hacer cocaína, también es cierto que el acullico, práctica ancestral que consiste en la masticación directa de la propia planta, no tiene nada que ver con la preparación y el consumo de la cocaína, que es el resultado de un proceso químico. Por ese motivo, la dimensión cultural ancestral del acullico se opone claramente al tráfico de la droga moderna denominada cocaína. De hecho, en Bolivia, hasta el período del presidente Banzer, su cultivo era libre.

Por otro lado, entre 1860 y 1910 empezaron a surgir las redes comerciales internacionales en torno a la producción de coca / cocaína, lo que llevó a la amalgama de ambos productos. Sin embargo, entre 1910 y 1950, se llevó a cabo un control estricto de su producción y de los

\footnotetext{
${ }^{41}$ Coca (Planta), (Erythroxylum coca). Es un arbusto de la familia de las Eritroxiláceas originaria de las escarpadas estribaciones de los Andes amazónicos, propia de América del Sur, con nutrientes medicinales y alimenticios. Sus cuatro variedades más notables son "Lambram", "Mollecoca", "Fusiforme", "ovoide" con hojas alternas, aovadas, enteras de estípulas axilares y de flores blanquecinas (https://www.ecured.cu/Coca_(planta))

Tesis de Maestría
} 
intercambios. Al mismo tiempo, tanto las organizaciones internacionales como las redes regionales estadounidenses, europeas y pan-asiáticas del Imperio japonés comenzaron a regular estas actividades con severidad. En 1925, durante la segunda Conferencia Internacional sobre el Opio dentro del marco de la SDN (Sociedad De Naciones) se declaró que la coca era perjudicial para la salud. La delegación boliviana rechazó la declaración justificándola a través del argumento cultural legitimando la producción y el consumo de coca. A pesar de ello, en 1948, la ONU llevó a cabo un estudio del tema en Perú y Bolivia. Pocos años después, los resultados del informe sobre el caso establecía vínculos entre los efectos de la masticación de coca y la elaboración de cocaína: desnutrición, trastornos de tipo intelectual y psicológico, reducción del rendimiento económico y laboral, etc. En 1957, la Comisión de Estupefacientes de la ONU se congratulaba por el hecho de que la legislación boliviana en vigor tenía previsto prohibir la masticación de la hoja de coca en el país. El desenlace tuvo lugar dos años más tarde cuando la Comisión del Control del Opio estableció un vínculo entre coca y cocaína: "la masticación de las hojas de coca es la principal causa del tráfico internacional ilícito, al que también se destina la fabricación clandestina de cocaína" (Convención Internacional del Opio de 1912, sustituida por la Convención única sobre estupefacientes de 1961), algo que fue corroborado por numerosos informes de la ONU. Sin embargo, la realidad es muy distinta.

En 1960, sucedió lo ineludible: la Comisión del Control del Opio declaró oficialmente que Bolivia y Perú no habían cumplido sus compromisos, ya que no habían reducido su producción de coca. Además, Bolivia utilizaba solamente la mitad de su producción anual para la masticación, por lo que la otra mitad que quedaba no se utilizaba para ningún fin en particular, si bien dejaba abierta la posibilidad de que esa parte se pudiera utilizar para la fabricación clandestina de cocaína. Esta interpretación se tradujo en la demonización del acullico indígena y, como consecuencia de ello, el principio igualmente de la guerra contra el cultivo, la producción y el consumo de coca. Con el fin de garantizar el cumplimiento de los nuevos compromisos peruanos y bolivianos, en 1968 se constituyó la “Junta Internacional de Fiscalización de Estupefacientes" y, con ella, se formalizó la necesidad de velar por la seguridad internacional.

En 2012, la producción de cocaína en Colombia y Perú aumentó, mientras que en Bolivia disminuyó (Oficina de Naciones Unidas Contra la Droga y el Delito (2013)). La política claramente antiimperialista de Evo Morales y el papel de Bolivia en el narcotráfico preocupa a EE.UU. y, a lo largo, la sociedad internacional: es diferente del que desempeñan los gobiernos colombiano y peruano, que mantienen relaciones políticas y comerciales con EE.UU. Además, el hecho de que Bolivia se niegue a cambiar su legislación sobre el acullico, no hace sino aumentar 
la tensión entre ellos. De este enredo político surge un debate encendido: la sociedad internacional, insiste en el papel "irreverente" de Bolivia para etiquetarla, denunciarla y aislarla de la comunidad internacional. Habida cuenta de estas observaciones, la guerra de la coca librada por la sociedad internacional contra la región andina, y más especialmente contra Bolivia, nos invita a intentar discernir cuáles son las razones de tal demonización.

\section{Mapeo sobre los cultivos de coca en Sudamérica}

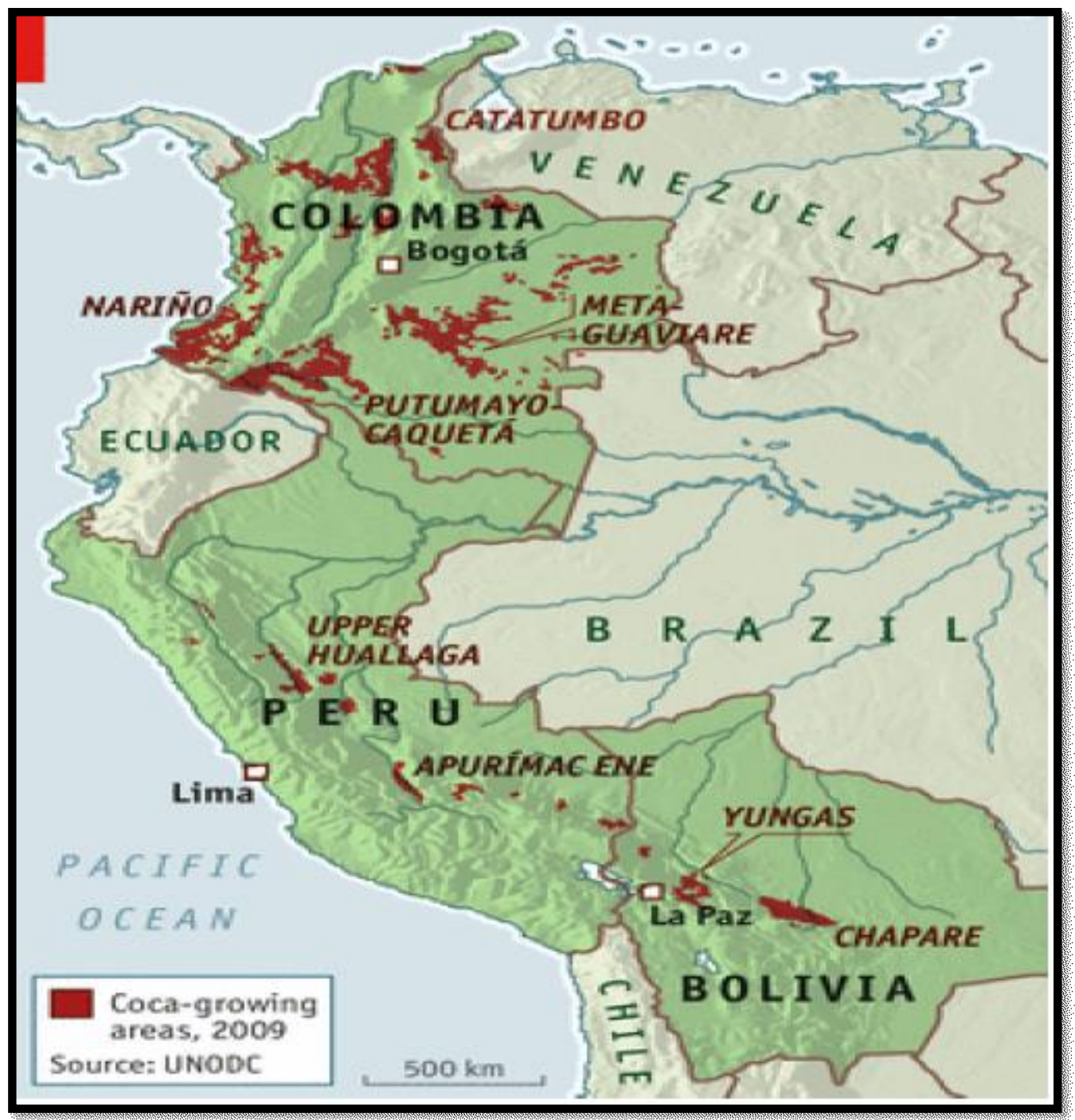

Las estadísticas siguen (Oficina de Naciones Unidas Contra la Droga y el Delito (2010)) sin aportar información alguna sobre el uso que se le da a la coca. Además, no se distingue entre coca y cocaína: el cultivo de la planta está vinculado automáticamente a la producción de droga. Resulta que la región andina es considerada como el epicentro del narcotráfico en América Latina, justificando posibles prácticas de intervencionismo que, en ocasiones, más tendrían que ver con una forma de injerencia. Sin embargo, los conceptos de intervención y de injerencia corresponden a dos procesos distintos: el primero implica solamente la interferencia de un estado Tesis de Maestría 
en las competencias de otro, mientras que el segundo implica una intromisión en la gestión del estado sin la autorización de éste. Se trata de una intervención del "exterior" en el "interior" de una entidad establecida sin que ningún instrumento jurídico exista entre los estados. En el caso del acullico, esta práctica va pasando de un proceso a otro. Sin embargo, la multitud de formas bajo las que se puede manifestar la injerencia hace que se la pueda denominar de diversos modos y que se de en diversos tipos de situaciones que se podrían calificar como intervencionistas. No obstante, dentro de la definición de injerencia cabe distinguir dos tipos: la injerencia material y la injerencia inmaterial. La primera implica una penetración y, por consiguiente, une presencia física en el territorio de un estado que la rechaza, mientras que la segunda no implica ninguna presencia física sino una fuerte presión política. En el caso del acullico, declarar la necesidad de una intervención con la excusa de proteger a la sociedad internacional, generalmente calificado de apoyo o de ayuda internacional, se asemeja a un argumento para justificar un proceso de injerencia. Tanto si se trata de injerencia material como inmaterial, en el caso del acullico la injerencia se manifiesta a nivel internacional, regional y nacional, adoptando distintas formas: democrática, legitima y contra-injerencia.

La injerencia democrática es el resultado de la voluntad global de los estados de la sociedad internacional. No se puede poner freno a este tipo de intervención de un país en el territorio de otro. La injerencia democrática conlleva una obligación que está por encima de las leyes: si un estado no la respeta, deja de ser solidario con el resto de la comunidad. Por lo tanto, aceptar esta forma de injerencia es casi inevitable. En el caso del acullico, tal forma de injerencia es la consecuencia de la insistencia de EE. UU., preocupados sobremanera por los flujos de cocaína provenientes de la región andina. Aunque la sociedad internacional tenga un papel importante en toda la presión ejercida sobre Bolivia, la política estadunidense es la que llama más la atención. Sin embargo, la pluralidad de estados dentro de la escena internacional y, por consiguiente, de intereses, puede conducir al fracaso de la estrategia de injerencia democrática. Así, en el caso del acullico, a la injerencia internacional se le suma la de dimensión regional, que en realidad se asemeja más a una forma de intervencionismo.

La práctica de la injerencia regional, por su parte, se presenta como una necesidad. La propia idea de prevención implica una acción de anticipación y no una acción de sanción, algo que hace que el estado en cuestión se sienta menos agredido o, por lo menos, que no se ofenda. Además, su práctica a nivel regional, debido a su dimensión menos agresiva, hace que llegue a parecer una forma de cooperación, lo que le confiere una cierta legitimidad. En el caso del acullico, la 
injerencia legítima se manifiesta a través de una forma de "acordonamiento" de Bolivia. La sociedad internacional, y en flagrante EE.UU., utiliza alternativamente injerencia material e inmaterial, interviniendo en la gestión y la defensa de los valores culturales bolivianos sin tener en cuenta la voluntad de Evo Morales de respaldar la cultura boliviana y asegurar su respeto por el derecho constitucional. EE.UU. alterna pues presión diplomática, sanción jurídica y presencia militar en los países de la región andina en parte para que Bolivia rectifique y abandone el cultivo de coca.

En respuesta a estas técnicas, queda solamente una posibilidad: la contra-injerencia, que se traduce en el fortalecimiento del derecho nacional a pesar del necesario respeto a las obligaciones y compromisos internacionales.

En una situación de injerencia, la soberanía queda en entredicho. En este caso, la multitud de aspectos y de formas de injerencias utilizadas no permite concentrarse en este debate: lo que se plantea es cómo el derecho aborda la cuestión del elemento cultural. En otras palabras, en el caso de acullico, ¿qué papel desempeña el derecho cuando la protección de los valores culturales entra en conflicto con la necesaria protección de la seguridad internacional? La necesidad de acatar la voluntad de la sociedad internacional favorece la práctica de una injerencia democrática (II) a pesar del respeto de los valores culturales nacionales. Sin embargo, los vínculos culturales, económicos y políticos de los países andinos se acabarán utilizando en su contra para legitimar esta forma de injerencia, que oscila claramente entre su expresión material y su expresión inmaterial, además de acercarse a una situación de intervencionismo (III). Resulta que el gobierno boliviano desarrolló una estrategia de contra-injerencia para proteger el acullico (IV) y desmarcarse de tales prácticas ${ }^{42}$

\footnotetext{
${ }^{42}$ Meryl Thiel1 (2014) "Acullico y narcotráfico - Cuestionar la injerencia" - disponible en https://www.bolivianstudies.org/revista/11.1/11.01.008.Thiel.pdf Tesis de Maestría
} 


\section{CAPITULO II:}

\section{$\underline{\text { El Narcotráfico en el contexto del Crimen Organizado Internacional }}$}

Toda la temática que esta directa o indirectamente relacionada con el Crimen Organizado es observado desde diferentes perspectivas, que introducen diversos elementos causales y explicativos, desde el punto de vista general, se considera que el crimen organizado tal y como lo conocemos hoy día, tiene un origen muy contemporáneo, que remite a la segunda mitad del siglo XIX; y aparece asociado a la expansión incipiente del comercio mundial, el imperialismo europeo, la rápida urbanización, los intensos cambios sociales y los nuevos procesos migratorios tanto internos como internacionales; en cierto modo hablamos de GLOBALIZACION ${ }^{43}$. Con las transformaciones internacionales que dieron fin de la Guerra Fría y el avance de las nuevas tecnologías, el crimen organizado adquirió una nueva dimensión espacial. Supuso un punto de inflexión que, según Jorge Chabat, visibilizó de manera creciente la amenaza del crimen organizado. En concreto, adoptó nuevas formas organizativas que posibilitó una mayor transnacionalización del mismo ${ }^{44}$.

El delito transnacional organizado describe un proceso evolutivo de estos grupos dividido en tres fases a saber (Se agregan comentarios de Juan Gabriel Tokatlian en La Nación del 11/2/14)

\section{Fase Predatoria:}

Se distingue por la afirmación territorial de grupos criminales que garantizan su poderío por medio de la violencia y con ello logran defender su empresa ilícita, eliminar rivales y afianzar un monopolio privado de la fuerza. En esta etapa el territorio y su control son fundamentales. Ello obedece a varias razones: deben manejar uno o varios bienes ilícitos en un espacio físico seguro; deben afianzar las rutas para el transporte de dichos bienes; deben tener acceso a mercados para realizar sus productos, y deben proveerse de ámbitos de protección personal. El territorio

\footnotetext{
${ }^{43}$ La globalización es un fenómeno inevitable en la historia humana que ha acercado el mundo a través del intercambio de bienes y productos, información, conocimientos y cultura.

En las últimas décadas, esta integración mundial ha cobrado velocidad de forma espectacular debido a los avances sin precedentes en la tecnología, las comunicaciones, la ciencia, el transporte y la industria.

Si bien la globalización es a la vez un catalizador y una consecuencia del progreso humano, es también un proceso caótico que requiere ajustes y plantea desafíos y problemas importantes - http://www.un.org/es/aboutun/booklet/globalization.shtml

44 https://riull.ull.es/xmlui/bitstream/handle/915/915/El\%20crimen $\% 20$ organizado $\% 20 \mathrm{y} \% 20 \mathrm{el} \% 20$ narcotrafico $\% 20 \mathrm{en} \% 20 \mathrm{el} \%$

20panorama $\% 20$ internacional.pdf? sequence $=1$

Tesis de Maestría
} 
dominado es esencial para defender el negocio ilegal; eliminar competidores; obtener influencia sociopolítica, y garantizar la supervivencia física.

En dichos territorios hay diversas formas de violencia que al principio son esporádicas y después se incrementan. Por una parte, está la rivalidad entre grupos criminales, que genera disputas. Esta forma de violencia no pareciera interesarles mucho ni al Estado ni a la sociedad, prevalece la lógica de "que se maten entre ellos". Por otra parte, está la cooptación forzada, la amenaza sugerente o la ejecución directa de algunos actores que, a nivel municipal o provincial, tienen cierto poder: intendentes, jueces, policías, entre otros. Esta forma de violencia inquieta, pero no alarma demasiado, la lógica prevaleciente, tanto institucional como social, es "no hacer muchas olas". Y, por último, está el atentado contra algún funcionario público o un líder político

\section{Fase Parasitaria:}

Denominada por Juan Gabriel Tokatlian como de las 4 "P" Pandillas, Policía, Políticos y Privados (unificación de los actores de la corrupción) Implica una substancial influencia política y económica combinada con una evidente capacidad corruptora de sectores públicos y privados. A esa altura, la influencia política y económica de la criminalidad aumenta notoriamente. Esta fase no sólo muestra la mayor inserción del crimen organizado, sino también tres dinámicas preocupantes: su "legitimación", "proliferación" y "democratización". Por legitimación se entiende el creciente nivel de aceptación y reconocimiento de dicha criminalidad por parte de la sociedad. Por ejemplo, en el caso del narcotráfico, sus dineros son aceptados por amplias franjas sociales, sus modos de vida fastuosos no son cuestionados y su visibilidad en ámbitos típicos de las elites no despierta rechazo. Por proliferación se entiende la diversificación de sus inversiones; en particular en emprendimientos legales, tanto en el campo como en las ciudades. Y por democratización se entiende la multiplicación de emporios criminales, desde grandes carteles hasta cartelitos y desde organizaciones jerárquicas clásicas del estilo mafioso hasta estructuras reticulares más sofisticadas. Todas estas formas combinan violencia, cooptación y corrupción.

\section{Fase Simbiótica:}

Para lograr su afianzamiento, el sistema político-económico se vuelve tan dependiente del "parásito" (el crimen organizado) como este de las instituciones establecidas. En esta fase se manifiesta el afianzamiento de la criminalidad y el sistema político y económico se vuelve tan dependiente del "parásito" -esto es, del crimen organizado- como éste de la estructura 
establecida. La frontera entre lo lícito y lo ilícito, entre lo legítimo y lo ilegítimo se torna opaca y el Estado de Derecho mismo se diluye. En esta etapa tiende a ocurrir lo que denomino pax mafiosa. Un país no es plenamente capturado por el crimen organizado, pero en muchas regiones y provincias la simbiosis permite la consolidación de una nueva clase social -a nivel local- con aptitud y decisión de establecer un orden en ese espacio ante la desorientación de las elites dirigentes y la fragilidad estatal. No se trata de un modelo de ocupación del Estado central, sino de un tipo de pax en que una clase social maximiza su poder en los claroscuros de la intersección entre el Estado, la sociedad y el mercado.

Llegada a la última fase es poco probable que se produzca una reversión completa e inmediata mediante un inesperado conjunto virtuoso de políticas públicas. En la evolución narrada, el crimen organizado de la primera y la tercera fase no es el mismo. En el estadio "predatorio" hay pandillas e incipientes grupos criminales de tipo empresarial. En el estadio "parasitario" hay modalidades diversas de crimen organizado cada vez más entrelazado internacionalmente. En el estadio "simbiótico" hay claros indicios de que de aquellas bandas emergentes son parte del pasado, ahora despunta una clase social consolidada que tuvo su soporte original en los negocios ilícitos, pero que ya tiene nexos profundos y decisivos con la economía legal y el sistema político. En la primera etapa se estaba ante un hecho criminológico; en la tercera se afirma una cuestión sociológica ${ }^{45}$.

La dinámica de los procesos parasitarios y de simbiosis se aceleró con inusitada fuerza tras el fin de la Guerra Fría debido al desorden mundial que siguió tras la caída de la Unión Soviética; y la aparición del consiguiente vacío de poder, relajación de la seguridad y alteración de las pautas normativas y de comportamiento seguidas hasta entonces en buena parte del tradicional espacio de influencia soviético. A su vez, este proceso estuvo acompañado por el desarrollo de los diferentes instrumentos de interconexión global (TIC), que comenzaban entonces a despuntar con fuerza; y permitieron ensanchar los vínculos y conexiones del crimen organizado con ingentes beneficios al margen de la economía formal. Por tanto, no fue extraño que las mafias y sus asociados empresariales saltaran a la "era de la información" mucho más deprisa y ágilmente que las burocracias estatales.

Esta ventaja fue fundamental para desarrollar - y comprender - su enorme capacidad de control tanto de las redes de sus respectivos países como de las trasnacionales. Desde esta novedosa y

\footnotetext{
${ }^{45}$ GAYRAUD, JEAN-FRANCOIS (2007) “EL G9 DE LAS MAFIAS EN EL MUNDO” - TENDENCIAS Tesis de Maestría
} 
ventajosa posición, las nuevas redes y núcleos del crimen organizado establecieron alianzas estratégicas desde diferentes países con el fin de colaborar entre ellas, además de protegerse mutuamente en líneas generales, en lugar de combatirse estérilmente entre sí como tradicionalmente sucedía. En suma, actuaron como empresas en red, solo que fuera del marco legal, debido a su propia naturaleza delictiva. Además de mantener una estructura predominantemente patriarcal, que constituye también uno de sus rasgos definitorios, con una distribución del poder jerarquizada en la que el hombre ocupa un lugar preferente en detrimento de la mujer salvo en los casos en que ésta forma parte del núcleo familiar dirigente o la "familia" en el sentido clásico de las mafias. Con este renovado fortalecimiento, el crimen organizado ha conseguido penetrar en los mercados financieros, el comercio, las empresas e incluso en muchos sistemas políticos, socavándolos para sus propios intereses o estableciendo relaciones fuera de la legalidad. Como señala Manuel Castells: "Su estrategia consiste en ubicar sus funciones de gestión y producción en zonas de bajo riesgo, donde poseen un control relativo del entorno institucional, mientras que buscan sus mercados preferentes en las zonas de demanda más rica, a fin de cobrar precios más altos"

En esta misma dinámica, las actividades criminales en las últimas décadas han conseguido diversificarse respecto a su tradicional oferta aunque dependiendo de la organización, sus acciones están más enfocadas a un sector que a otro. En el caso de América Latina por ejemplo, los cárteles se centran fundamentalmente en el tráfico de drogas, originalmente cocaína y, luego, marihuana, heroína y otras drogas químicas.

Pero el tráfico de drogas, aunque está muy extendido, tiene un considerable impacto internacional y es el que más dinero mueve después del tráfico de armas, es solo una de las actividades criminales registradas a lo largo del mundo y que suelen acompañarse e incluso cruzarse o entremezclarse en los subterráneos de la delincuencia transnacional.

Además del mencionado tráfico de armas, principalmente ligeras (las que más matan en el mundo), cabe destacar también el contrabando de inmigrantes, engañados y explotados por las organizaciones criminales para rebasar los controles fronterizos y la obtención de residencia. El tráfico de mujeres y niños, muy ligado a la división sexual del trabajo, explotación sexual y prostitución, ocupando esta actividad el tercer puesto en volumen de dinero después del tráfico de armas y el narcotráfico. El tráfico de órganos, normalmente de muertos no reclamados, pero también de su venta (el riñón es el órgano más frecuente) por sectores sociales muy 
empobrecidos. El ejercicio de la violencia de todo tipo, utilizada habitualmente para hacer cumplir tratos, atemorizar, coaccionar, chantajear o "ajustar cuentas"; y que en ocasiones se vale de la subcontratación de asesinos a sueldo. Y por último, pero no menos importante, el blanqueo de dinero, que ha adquirido una notable importancia en la actual época del capitalismo especulativo-financiero y de los paraísos fiscales.

Respecto a la actividad de blanqueo, conviene destacar que todo el conjunto del sistema criminal solo tiene sentido si los beneficios generados se pueden reinvertir y usar en la economía legal. El blanqueo de capitales es la piedra angular de la delincuencia organizada transnacional, que se ve beneficiada por la existencia de los paraísos físcales y por los cauces de actuación que posibilita el sistema financiero internacional, que tienen muy pocos controles. Según Castells, el proceso de blanqueo de dinero se desarrolla en tres etapas. La primera requiere de la colocación del dinero, en efectivo, dentro del sistema financiero mediante la red bancaria. La segunda procede a separar los fondos monetarios de sus fuentes iniciales para evitar su detección por auditorias futuras. Por último, la tercera, introduce el capital blanqueado en la economía legal

\section{Conceptualización del crimen organizado a nivel internacional}

Una vez vista esta aproximación al crimen organizado, resulta igualmente pertinente recoger la definición y concepción avanzada en el ámbito institucional internacional. Desde el punto de vista jurídico existen varios conceptos de delincuencia organizada, según recogen las diversas organizaciones internacionales.

La Convención de Naciones Unidas sobre la Delincuencia Organizada Transnacional (CDOT), que conforma el marco jurídico básico a escala internacional en la lucha contra el crimen organizado, define un grupo delictivo organizado como 'una asociación estructurada de más de dos personas cuya conducta durante un cierto período de tiempo, actúe de manera concertada con el fin de cometer delitos sancionables con una pena privativa de libertad de al menos cuatro años, o con una pena más severa, independientemente de que esos delitos constituyan un fin en sí mismos o un medio para obtener beneficios patrimoniales y en su caso, de influir de manera indebida en el funcionamiento de la autoridad pública"

Los delitos que se incluyen en esta definición pueden ser el terrorismo, el narcotráfico, la trata de personas, el tráfico ilícito de inmigrantes, el blanqueo de capitales, el tráfico ilícito de material 
nuclear y radiactivo, y de vehículos robados. Posteriormente, en un anexo, se incluyó una lista adicional de delitos como la falsificación de moneda y de medios de pago, la falsificación y tráfico de documentos, el tráfico ilícito de armas, de bienes culturales, especies animales y vegetales protegidas, entre otros.

Otro de los mecanismos más relevantes creados en el espacio internacional para combatir el crimen organizado es la Convención de Palermo (15 de diciembre del 2000), que aborda el concepto de "grupo delictivo organizado" mediante una serie de criterios que son:

- Criterio del umbral numérico: el grupo delictivo organizado debe ser igual o superior a tres miembros.

- Criterio de concertación de las actividades delictivas organizadas: las actividades delictivas se deben enmarcar en una organización.

- Criterio de "delicta commissi": los delitos deben formar parte de una de las dos formas que contempla CDOT. Primero, pueden ser delitos calificados como graves que deben tener una pena máxima de 4 años o más; y segundo, los delitos que se encuentran dentro de la tipificación establecida por la CDOT como son "'grupo delictivo organizado", 'blanqueo del producto del delito", la "corrupción" y la denegación de "'asistencia judicial recíproca'.

- Criterio lucrativo: las actividades de estos grupos persiguen el enriquecimiento económico u algún otro tipo de enriquecimiento material.

- Criterio de transnacionalidad: este criterio se establece en base a dos conceptos establecidos por la CDOT. Primero, si el delito se comete en más de un Estado; y segundo, si el delito se comete en un solo Estado, pero la situación delictiva implica algún tipo de carácter transnacional.

Por su parte, el Consejo Europeo define el concepto de delincuencia organizada, en la “'Recomendación 11 de 2001', como 'un grupo de estructurado de tres o más personas existente por un período de tiempo y actuando concertadamente con el propósito de cometer uno o más delitos graves, con el objetivo de obtener directamente un beneficio financiero o material'". El Consejo establece cuatro criterios para observar si algo es un grupo delictivo organizado o no. Se requiere de la colaboración de tres o más personas, la prolongación en el tiempo de las actividades delictivas, las personas cometen delitos graves, y el objetivo de obtener 
un beneficio lucrativo a través de sus actividades criminales. El concepto de la CDOT y el del Consejo Europeo son muy parecidos, siendo este segundo más escueto.

Otro instrumento internacional es el Pacto Internacional de Derechos Económicos, Sociales y Culturales de Naciones Unidas, que entró en vigor el 23 de Marzo de 1976. Señala que las actividades ilícitas de la delincuencia organizada vulneran las disposiciones de dicho instrumento en lo relativo a las condiciones laborales de los grupos vulnerables (mujeres, niños e inmigrantes), explotados por los grupos de la criminalidad organizada. El instrumento recoge el derecho de toda persona a tener la oportunidad de ganarse la vida mediante un trabajo libremente escogido o aceptado.

Las redes de delincuencia también vulneran instrumentos jurídicos de la Organización Internacional del Trabajo (OIT) como su convenio sobre la abolición del trabajo forzoso, aprobado en Ginebra, el 25 de junio de 1957 y en vigor desde el 17 de enero de 1959.

Existen otras definiciones sobre el crimen organizado que, por lo general, recogen una serie de características definitorias comunes:

- Actividades criminales de naturaleza grave, cometidas de forma planeada con perspectiva de obtener beneficio.

- Una división del trabajo jerárquica de tipo empresarial y continua que incluye sanciones internas y disciplina.

- El uso de la violencia e intimidación como medio para obtener sus objetivos.

- El ejercicio de tráfico de influencias o la corrupción de varios funcionarios electos y nombrados u otros pilares de control social y líderes de opinión dentro de la sociedad.

Además, se trata principalmente de una actividad no ideológica, sino lucrativa y delictiva, que la diferencia de la violencia terrorista. Por último, hay que dejar claro la diferencia relevante en cuanto a su alcance existente entre el crimen organizado, con todas sus variedades (narcotráfico u otras), y el crimen común o delincuencia común desorganizada. El primero supone un enorme desafío al Estado y a la sociedad en términos de gobernabilidad y seguridad, mientras que el segundo carece de esa dimensión.

\section{Crimen Organizado y Narcotráfico}


En cuanto a la percepción del crimen organizado, tanto por parte de los Estados como de la opinión pública en general, Moisés Naím afirma que no son del todo conscientes de su extrema gravedad. En su libro Ilícitos, expone las tres malas ideas en las sociedades actuales existentes al respecto. La primera es pensar que no hay "nada nuevo", en el tema, ignorando los grandes cambios que ha experimentado el crimen organizado en la década de los 90, con la desaparición de las estructuras rígidas clásicas de las jerarquías criminales, la descentralización y desestructuración de sus actividades, unido a la aparición de nuevas formas de comercio ilícito a través de internet. La segunda es considerar que el comercio ilícito no es más que delincuencia estándar, pero el crimen organizado va mucho más allá, “invirtiendo las reglas, creando nuevos agentes y reconfigurando el poder en la política y la economía internacionales'”. Por último, la tercera, es la concepción de que el comercio ilícito es un fenómeno que se encuentra sumergido fuera de la vida "ordinaria". Considera que esta idea es la más peligrosa de las tres porque provoca en los ciudadanos un sentimiento de falsa seguridad, sin advertir que el comercio ilícito se ha introducido, de manera más o menos visible, en la vida de los ciudadanos de prácticamente todo el mundo; y también en las estructuras estatales: burocracia, fuerzas de seguridad, gobiernos, entre otras.

Mientras predomine este mensaje de seguridad falso, la población no podrá concienciarse para combatir el fenómeno. De hecho, las redes ilícitas han conseguido vincularse estrechamente con las actividades lícitas tanto del sector privado como del público, logrando en algunos casos establecer un control determinante de los mismos; y superando en recursos y medios al de algunos países. Un claro ejemplo de esto es México, donde el crimen organizado se encuentra en una fase de simbiosis tanto con las instituciones como con algunas empresas del país, superando en ganancias al propio país y dirigiendo muchas de sus decisiones.

Otro importante factor a tener en cuenta en la evolución del crimen organizado es el del significativo avance del capitalismo neoliberal. Las reformas económicas a escala mundial en el sistema financiero han beneficiado al comercio de ilícitos. Los gobiernos, obligados por los ajustes estructurales a reducir el gasto público, han tenido problemas para remunerar adecuadamente a sus funcionarios e incluso para pagarles sus salarios.

De aquí que busquen otra vías alternativas de supervivencia que, por lo general, propician la corrupción al intentar complementar sus sueldos. "Al mismo tiempo, la liberalización financiera ha aumentado la flexibilidad de los traficantes para invertir sus beneficios y el abanico de usos 
que pueden dar a su capital”. En suma, el crimen organizado está alterando el tejido social del conjunto de la sociedad mundial. No solo sus estructuras políticas y relaciones económicas están siendo afectadas, también su tejido social e incluso su expresión cultural debido a la interacción de amplios sectores de la población con este tipo de actividades.

Paralelamente, existen enormes dificultades para afrontar este problema a causa de la rigidez de las instituciones a la hora de articularse de manera eficaz frente a la mayor capacidad de movilidad mostrada por las redes delictivas. Como señala Naím: "Las redes delictivas crecen con la movilidad internacional y con su capacidad para aprovechar las oportunidades que emanan de la separación de los mercados en estados soberanos con fronteras. Estas fronteras terminan siendo obstáculos insuperables para los funcionarios encargados de darles caza. Los privilegios de la soberanía nacional se están convirtiendo, en una carga y una restricción para los gobiernos de cara a esta problemática',

Además de poseer condiciones propicias para su crecimiento, la clave del triunfo del crimen organizado, y del narcotráfico en particular, a escala mundial reside en la naturaleza de su condición de actor transnacional, que ha sabido aprovechar con mayor destreza y eficiencia los vericuetos de la globalización. En contraposición, el Estado posee un territorio demarcado y limitado. El margen de actuación e influencia de sus gobiernos está más definido y delimitado. La movilización de su aparato burocrático y de seguridad es más lenta y pesada. Por el contrario, las redes criminales son, en efecto, redes, con gran capacidad de maniobra debido a su flexibilidad y agilidad. Sin olvidar que al operar fuera de la ley, prácticamente no conocen más restricciones que la de sus recursos, fuerzas y estrategia. Por su parte, los gobiernos operan dentro de sus respectivos territorios de manera soberana, pero en el espacio internacional tiene que respetar una serie de pautas de actuación, predefinidas y predecibles. Las estructuras estatales poseen límites políticos y legislativos. Por tanto, es más fácil advertir de antemano su capacidad y margen de actuación. Sus limitados presupuestos no pueden dedicarse por entero a combatir las redes criminales o delictivas. De ahí que sus puntos débiles o vulnerabilidades sean objeto de las redes criminales y en especial del narcotráfico, dada su capacidad para importunar a las instituciones. En suma, en el combate entre las rígidas burocracias estales y la fluidez de las redes criminales, estas últimas presentan una mayor capacidad de adaptación a los cambios operados en la sociedad internacional a lo largo de las últimas décadas. El crimen organizado ha dejado de ser un problema nacional y, en su lugar, ha pasado a ser un desafío transnacional o 
global. Por tanto, la forma más pertinente de abordarlo es adoptando también medidas de cooperación transnacional o global, mediadas por una necesaria voluntad política.

\section{EI narcotráfico como nueva problemática mundial:}

El narcotráfico es una variedad del crimen organizado que consiste en la producción, distribución, venta y consumo, normalmente a gran escala, de drogas, adictivas o no, de manera ilegal, con el fin de obtener beneficios económicos. Estas drogas o estupefacientes suelen tener consecuencias negativas para la salud y están prohibidas en la mayoría de los países del mundo. Los grupos ilegales, mafias, cárteles y grupos narcotraficantes son los que se encargan de desarrollar esta actividad y suelen tener presencia internacional y ostentan muchas veces un poder similar al de algunos gobiernos.

Además de las definiciones desarrolladas por los organismos internacionales, muchos autores también han abordado la conceptualización del narcotráfico. Manuel Castells considera que para que exista el narcotráfico debe registrarse una serie características. Primero, que esté dirigido a la demanda y orientado a la exportación. Segundo, que sea una actividad plenamente internacionalizada, con una división del trabajo cambiante entre diferentes localizaciones y con un método de transporte efectivo y directo. Tercero, que el componente decisivo de la industria de la droga sea el sistema de blanqueo de dinero para la obtención de ganancias. Cuarto, que en el momento de las transacciones, se emplee de manera recurrente la coacción y el uso de la violencia extrema. Por último, quinto, que tenga la capacidad de corrupción y de penetración en los entornos institucionales y estatales. En suma, si cumple estas características, entonces se trata de narcotráfico. Para este autor es fundamental la legalización de algunas drogas para dificultar el narcotráfico. Esto es, dejarlo sin su razón de ser, pese a los riesgos que entraña esta medida.

Castells otorga una considerable importancia al uso de la violencia en el narcotráfico. Aunque éste no sea la causa de los conflictos armados, termina implantándose en situaciones de vacío de poder y desorden generalizado. Los ejemplos de Afganistán y Colombia son muy elocuentes. Países que combinan la conflictividad y la producción de drogas, retroalimentándose mutuamente. Algunas de las partes involucradas en el conflicto forman parte del narcotráfico o mantienen relaciones con el mismo para recabar ingresos; $y$, viceversa, el narcotráfico se vale de los conflicto para rentabilizar sus negocios antes la mayor vulnerabilidad que presentan esos países. 
Por otra parte, para Moisés Naím el narcotráfico es un problema global en el que todos los actores, incluidos los gobiernos, forman parte ya sea de forma directa o indirecta. En el actual negocio de la droga se ha producido un salto cualitativo en su organización.

Las antiguas mafias han dejado paso a un modo de operar basado en células, mucho más ágiles y difíciles de rastrear. Sin menospreciar que las drogas han penetrado en prácticamente todos los sectores sociales, desde los de menor poder adquisitivo como jóvenes y estudiantes hasta los círculos empresariales y altas esferas. En suma, no hay esfera social que escape a las redes del narcotráfico. Precisamente, las de mayor poder económico y financiero son las que tienen mayor capacidad, en particular, para mover el capital financiero ilegal, que aparece vinculado a los paraísos fiscales como Suiza, entre otros. Con la globalización los paraísos fiscales se han extendido por el mundo, y no en pocas ocasiones aparecen asociados al crimen organizado.

Por su parte, Jorge Chabat considera que el narcotráfico es la actividad ilegal más lucrativa y visible del crimen organizado transnacional; y destaca su enorme capacidad para desestabilizar a los Estados más frágiles, generar ingobernabilidad y amenazar la viabilidad de muchos otros Estados. Este autor advierte dos características definitorias, una, su gran capacidad para acumular ganancias en periodos muy cortos de tiempo; y dos, que es un delito consensuado entre ambas partes, que están de acuerdo en la transacción, característica que ilustra un poder corruptor sin paralelo. En este sentido, Chabat resalta la dificultad para combatir el narcotráfico por las autoridades, dado que los consumidores son parte colaborativa del delito.

México se ha convertido durante los últimos años en caso muy relevante de este tipo de situaciones. En este país el crimen organizado, y por extensión, el narcotráfico, está en gran parte entremezclado con los aparatos de seguridad del Estado, mostrando su poder de corrupción; además de la influencia que ejerce el narco en las decisiones estatales. Sin olvidar la extensión de la ingobernabilidad a una buena parte de su territorio, donde los intereses del narcotráfico se contraponen a las que deberían ser las obligaciones y tareas del Estado mexicano.

\section{$\underline{\text { El narcotráfico desde una perspectiva internacional }}$}

Un panorama sobre el estado de la droga en el mundo es propiciado anualmente por el Informe Mundial sobre las Drogas, que muestra la evolución de los mercados de las drogas, que abarca 
desde la producción hasta el consumo así como de sus efectos en las poblaciones. Este trabajo se hace eco del último informe disponible, de 2014. A grandes rasgos se observa que la prevalencia mundial del consumo de drogas ilícitas se mantiene estable y que se va ajustando poco a poco al aumento de la población mundial. El consumo de drogas sigue causando un daño considerable, cifrado en pérdida de vidas y, en particular, pérdida de años de productividad de las personas, que es la parte que más interesa a los gobiernos. En 2012 se informó de un total aproximado de 183.000 muertes relacionadas con las drogas en la población entre 15 y 64 años. Para el mismo año, se calcula que entre 162 y 324 millones de personas consumieron, por lo menos una vez, algún tipo de droga ilícita. Sin embargo, se señala que el consumo de drogas más problemático, de personas que sufren dependencia o problemas a través de las mismas, se mantiene estable entre los 16 y 39 millones de personas. De estas solo uno de cada seis consumidores de drogas problemáticos del mundo ha tenido acceso a algún tipo de tratamiento de drogodependencia

Durante el último decenio se ha experimentado un aumento del número de personas que se someten a tratamientos por trastornos relacionados con el cannabis, a pesar de ser considerada una droga menos dañina, sin embargo, los opiáceos siguen siendo la principal droga objeto de abuso en la mayor parte del mundo. También se observa que en algunas zonas del mundo, especialmente en Europa oriental y sudoriental, la tasa de consumo de drogas por inyección ha aumentado hasta 4,6 veces por encima del promedio mundial. Esto, a su vez, desencadena una mayor exposición a la aparición de enfermedades como el VIH o la hepatitis C. Se calcula que una media del 13,1 por ciento de esas personas viven con el VIH; y en ámbito mundial 1,7 millones de consumidores de drogas por inyección viven con dicha enfermedad.

Además, un porcentaje muy elevado de consumidores de drogas por inyección tienen un historial de reclusión. Aquí entran en juego las cárceles, la escasez de servicios de atención de la salud o la dificultad para acceder a ellos por parte de los consumidores. La crisis financiera en Europa ha repercutido de manera significativa en el consumo de drogas y, en particular, en sus consecuencias sanitarias y sociales. Situación no ajena a la reducción de la cobertura de los servicios preventivos, así como de la capacidad de reducir los daños.

Por el tipo de drogas más comunes en la escena mundial, cabe destacar primero los opiáceos, que encabezan la lista de sustancias problemáticas con más muertes y enfermedades a nivel mundial. Por tercer año consecutivo, Afganistán sigue siendo el país predominante en el cultivo de estas drogas, con un aumento de la superficie de cultivo de la misma. En 2013, la producción estimada 
de heroína aumentó. Además, existen indicios de que la heroína afgana está llegando a mercados nuevos, como pueden ser Oceanía y Asia sudoriental. Sin embargo, su consumo se ha reducido en Europa occidental y central, debido en parte a la mayor eficacia de su persecución, y también a los cambios en la oferta y demanda en estos mercados. En Estados Unidos se ha observado que la aparición de opioides sintéticos está reemplazando a la heroína tradicional debido al menor coste de la misma.

En segundo lugar, cabe destacar a la cocaína. La cocaína ha experimentado una disminución de su disponibilidad a nivel mundial. Su consumo se concentra principalmente en América, Europa y Oceanía, mientras que su producción principal se localiza en América del Sur. El consumo más problemático se registra en América Central y del Sur debido a su cercanía a los centros de producción. También está brotando su tráfico en África debido a la proliferación de su tránsito por este continente. Su incautación sigue aumentando, en 2011 se pasó de 634 toneladas a 671 en 2012. Pese a su fuerte presencia mundial, la cocaína pierde terreno frente a otras drogas en algunas partes del mundo, más fáciles de obtener y menos costosas. (Obsérvese el siguiente cuadro $^{46}$ )

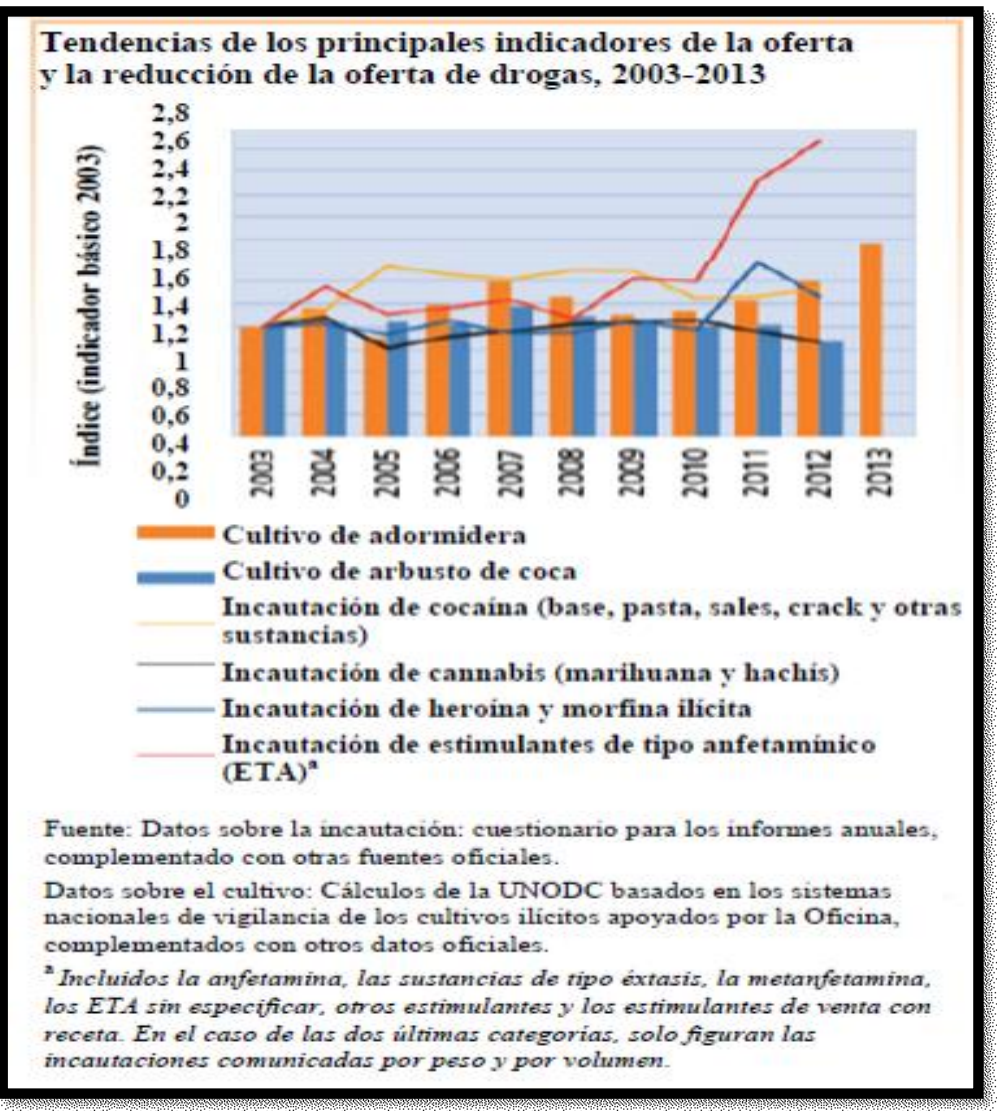

\footnotetext{
${ }^{46}$ UNODC (2014) "Resumen ejecutivo del Informe Mundial Sobre las Drogas". Oficina de las Naciones Unidas contra la Droga y el Delito, p. 4

Tesis de Maestría
} 
En tercer lugar aparece el cannabis o marihuana. Su cultivo y producción está generalizado a nivel mundial. Sin embargo, se observa que la producción de hachís (derivado del cannabis), se está concentrando en África del Norte, y en algunos países de Oriente Medio y Asia. Si bien su consumo se reduce a nivel mundial, en Estados Unidos y otros países aumenta debido a la extendida percepción de que el cannabis no es tan peligroso. Su consumo suele darse entre los jóvenes, principalmente, que tienen una menor percepción del riesgo; además de contar con una mayor y más fácil acceso. En los Estados de Colorado y Washington, así como en Uruguay, se ha legalizado el consumo recreativo de esta droga, con algunas restricciones. Pero todavía no es posible evaluar el efecto de esta iniciativa. Aunque muchos expertos consideran que es una forma de frenar el narcotráfico, aún no se sabe qué efecto surtirá ni si generará algunas consecuencias la salud, la justicia, los ingresos y gastos públicos.

En cuarto lugar, los estimulantes de tipo anfetamínico han experimentado un significativo aumento. Se observa un aumento del número de laboratorios en el mundo que fabrican estas sustancias, en particular la metanfetamina. De hecho, la producción de esta droga ha aumentado en América del Norte, que equivale a la mitad de la producción mundial, y por ello, también ha aumentado el número de incautaciones en dicha zona. Asia sudoccidental también se ha convertido en una zona importante de producción de metanfetamina destinada principalmente al mercado oriental. En 2012 aumentó también el volumen de incautaciones de éxtasis en Asia y en Europa. En este último continente representó más del 80 por ciento de la incautación a nivel mundial de esta sustancia.

Es importante señalar la proliferación de nuevas sustancias psicoactivas y el uso de principalmente internet, como un nuevo mercado de drogas. El tráfico de drogas está empleando lo que se denomina 'red oscura', para el comercio ilícito. Esta red constituye un mercado virtual muy difícil de controlar por parte de las autoridades debido a que los propietarios usan mecanismos muy complejos para ocultar su identidad. Los usuarios de estas redes usan principalmente monedas digitales o códigos de un solo uso que dificulta rastrear las transacciones. Se observa que tanto la diversidad de drogas en oferta y el valor de las transacciones por este medio aumentan cada año. También se observa la aparición de nuevas sustancias psicoactivas, aparte de la cocaína, heroína, MDMA, etc., hasta tal punto que dichas sustancias de diversa índole ya superan en número a las sujetas a fiscalización internacional. 
De aquí que en el mencionado informe se señale que es unos de los principales desafíos que tienen por delante los organismos internacionales. En este sentido, se han iniciado algunas nuevas medidas como la fiscalización de los precursores, que son los componentes indispensables de las sustancias químicas, y que una vez unidos forman el producto final. A través de esto, se pretende controlar la oferta de las drogas, dado que los enfoques tradicionales - como la erradicación de los cultivos ilícitos y el desarrollo alternativo- ya no funcionan para enfrentar el mundo de las drogas sintéticas. Con esta fiscalización se pretende orientar el uso de estas sustancias para el comercio legal y desviarlas de la fabricación de sustancias ilícitas. Pero al tratarse de algo sumamente cambiante, a pesar de que se han producido algunos logros, se están generando constantemente nuevas dificultades para este sistema debido, por ejemplo, al cambio de formulación de las drogas por parte de los fabricantes de drogas ilícitas, entre otras estratagemas

\section{$\underline{\text { EI narcotráfico en la agenda internacional de seguridad }}$}

Durante el transcurso de los años noventa, la literatura sobre seguridad internacional invirtió gran parte de su energía en identificar si, como resultado del fin de la Guerra Fría y procesos convergentes (tales como la interdependencia compleja, el regionalismo, los avances de la globalización y la difusión de la democracia), se había producido un cambio en la naturaleza de las amenazas. En este respecto, mientras declinaba la probabilidad de la guerra entre estados, emergían nuevas amenazas, nuevos desafíos y nuevos conflictos ${ }^{47}$. De esta manera se define a las Nuevas Amenazas como:

"un conjunto de fenómenos caracterizados por altos grados de violencia, vinculados principalmente al fin de la confrontación entre bloques, la disolución de la URSS y las condiciones creadas por el proceso de globalización. La proliferación de tecnologías sensibles y su creciente accesibilidad para países no confiables e incluso para grupos terroristas, los incrementos colosales del terrorismo y la violencia politica bajo diversas formas, la diversificación y la expansión del narcotráfico y sus actividades conexas son sólo algunos de los patrones de configuración de las Nuevas Amenazas".

\footnotetext{
${ }^{47}$ Fontana, Andrés (2003). Nuevas amenazas: implicancias para la Seguridad Internacional y el empleo de las Fuerzas Armadas. Documento de Trabajo $\mathrm{N}^{\circ}$ 103, Universidad de Belgrano. Disponible en la red: http://www.ub.edu.ar/investigaciones/dt_nuevos/103_fontana.pdf Tesis de Maestría
} 
De esta forma se sostiene que estos fenómenos no son amenazas en el sentido que tradicionalmente se consideraba en las agendas de las políticas de defensa y seguridad internacional. Para el autor, las amenazas plasmadas en la agenda de seguridad clásica son las que provienen de posibles agresiones calculadas, que afectan la soberanía o la integridad territorial de los estados e implican el empleo, real o potencial, de medios militares para su materialización, para responder a ellas o para neutralizarlas anticipadamente ${ }^{48}$

Por el contrario, las nuevas amenazas no se orientan hacia un objetivo determinado, constituyen más bien, fuentes de riesgo para las sociedades, las personas, las identidades nacionales, los valores democráticos, las instituciones financieras y los ordenamientos y códigos de conducta mundiales. Asimismo, sus alcances potenciales son amplios, donde no queda excluido ningún país y ningún individuo.

Según Fontana estos fenómenos configuran un contexto de incertidumbre debido fundamentalmente a tres factores: primeramente porque no existe una configuración previa de la amenaza, en segundo lugar por las grandes dificultades para anticiparla y, finalmente por la no previsibilidad de los medios adecuados para enfrentarlas. Además, agrega que estas Nuevas Amenaza no son, en la mayoría de los casos, verdaderamente nuevas ya que se refieren a fenómenos preexistentes que se han reactivado o agravado como consecuencia del fin de la Guerra Fría y del impacto de la globalización. Sin embargo, agrega que lo novedoso de estos fenómenos es que se han transnacionalizado y globalizado asumiendo un alcance que trasciende las previsiones con que tradicionalmente se enfocan las cuestiones de seguridad interior, defensa nacional y seguridad internacional

El autor clasifica estos fenómenos en tres grupos. Primeramente denomina amenazas emergentes a aquellas amenazas que no disputan formalmente la soberanía del estado ni su integridad territorial, pero afectan a las instituciones y a la integridad física y moral de las personas. En este grupo se encuentra el narcotráfico, el terrorismo, el crimen organizado y otras estructuras delictivas de carácter transnacional. En segundo lugar se encuentran aquellos factores de riesgo cuya peligrosidad no requiere la existencia de una voluntad hostil como ser la acumulación de desechos nucleares, las armas químicas arrojadas a los mares y la existencia de armas químicas y bacteriológicas. Finalmente constituyen el tercer grupo aquellos que no constituyen necesariamente amenazas para terceros como ser las migraciones masivas, las guerras intra-

\footnotetext{
${ }^{48}$ Fontana, Andrés. Complejidad de Riesgo e Interdependencia. Tendencias de cambio en la seguridad internacional. Documento de Trabajo N ${ }^{\circ}$ 24. Buenos Aires: Instituto del Servicio Exterior de la Nación, 1997.67 p Tesis de Maestría
} 
estatales, las persecuciones y matanzas de minorías y las etnias o religiones enfrentadas en un mismo territorio. El autor señala que estos fenómenos del tercer grupo son fuentes de inestabilidad antes que amenazas o factores de riesgo en sentido estricto.

Uno de los autores citados oportunamente caracteriza al contexto internacional por los siguientes rasgos:

- Los desafíos en materia de seguridad tienden a superar la capacidad individual de los Estados para hacerles frente.

- La seguridad de cada Estado depende más de las políticas que llevan a cabo otros Estados que del desarrollo autónomo de capacidades individuales de respuesta.

- Los Estados tienden a asumir formas asociativas y cooperativas en materia de seguridad, que a su vez incrementan la dependencia de la seguridad individual de cada Estado del complejo tramado de relaciones en la que se halla inserto.

Por lo anterior, se puede afirmar que en el marco de un contexto mundial cambiante, se despliegan nuevos y más complejos fenómenos que conducen a los estados a establecer una agenda de varias temáticas buscando formas alternativas al ámbito militar para abordar los nuevos desafíos que se presentan. A su vez, se puede deducir que el fenómeno del narcotráfico corresponde a las llamadas amenazas emergentes, las cuales presentan un gran desafío para la comunidad internacional y se encuentran inmersas en la nueva agenda de seguridad mundial. De aquí surge la tendencia de los estados a crear mecanismos de cooperación entre ellos lo que incrementa la interdependencia en materia de seguridad.

Interdependencia en su definición más simple, significa dependencia mutua. En política mundial, interdependencia se refiere a situaciones caracterizadas por efectos recíprocos entre países o entre actores en diferentes países En este respecto, la interdependencia en materia de seguridad se vincula estrechamente al carácter global o transnacional que asumen algunas amenazas y fuentes de riesgo. La existencia de amenazas de carácter global, implica consecuencias importantes en relación al comportamiento de los Estados en materia de seguridad. Más aún, en forma creciente, lo que ocurre en cualquier punto del planeta afecta puede afectar a la seguridad del conjunto aumentando los compromisos cooperativos regionales y globales. 
De acuerdo con Celia Toro, el problema del narcotráfico pasa a ser visto como un problema de interdependencia mutua entre dos mercados ilegales. Es decir que, como la oferta y la demanda son dos aspectos relacionados en un mismo mercado, tanto los productores como los consumidores deben tomar la responsabilidad de afrontar el reto, obligando a una colaboración integral que posibilite una lucha adecuada ante este problema.

En un acuerdo bilateral de lucha contra el narcotráfico entre un país de gran demanda como Estados Unidos y, un país con las dimensiones de oferta que tiene Bolivia, se puede afirmar que existe una relación de interdependencia. Esto se debe a que el fenómeno transcurre en ambos países, los cuales coexisten con esta problemática protagonizada por actores no estatales. En este respecto, lo que sucede en un país, afecta al otro; si en Bolivia aumentan los cultivos de hoja de coca excedentarios para fines ilícitos, Estados Unidos registrará un mayor ingreso de cocaína a su país. Esto convierte al narcotráfico en un condicionante de las relaciones exteriores entre las naciones.

Como se mencionó anteriormente, el carácter transnacional del narcotráfico ha conducido a los actores internacionales a crear acuerdos multilaterales, regionales y bilaterales enfocados en combatirlo. A fines de la década de los años cuarenta el consejo económico y social de las Naciones Unidas decidió establecer una comisión de investigación sobre los efectos de la masticación de la hoja de coca destacándose las siguientes conclusiones: a) la masticación crea hábito; b )inhibe la sensación de hambre, manteniendo una desnutrición constante en la población demandantes; y, c) a pesar de que las hojas contienen vitaminas y tienen un valor nutritivo como otros vegetales verdes, no se aconseja su consumo por contener alcaloides tóxicos, entre los que se encuentre la cocaína. Esta recomendación de la comisión fue ampliamente apoyada por la ONU lo cual condujo a promover la regulación del consumo de la hoja de coca bajo tratados internacionales. Así, la Convención Única sobre Estupefacientes celebrada en Viena el año 1961 se constituye como la piedra angular de la política internacional contra el tráfico de drogas. El objetivo del acuerdo busca limitar la producción, el tratamiento, distribución, importación, exportación, venta, posesión y uso de estupefacientes a fines exclusivamente médicos y científicos.

En esta convención, la hoja de coca está definida como estupefaciente y está incluida en la lista de substancias controladas (artículo 1, secciones e, f, j). Asimismo, se establece la necesidad de que los productores campesinos de la hoja posean una licencia que especifique el tamaño y 
ubicación de sus tierras registradas (Artículos 23 y 26), además de prohibir la masticación por 25 años.

A partir del análisis de las nuevas amenazas, se entiende que el narcotráfico es un mal que atenta contra la estructura social, económica y política de los países y, posiblemente sea una de las peores herencias para las futuras generaciones. Asimismo, la expansión de las áreas destinadas a la producción de coca, destruye los parques y reservas nacionales y las fábricas de droga contaminan los cauces de agua, afectando a la gente y a la fauna.

Bolivia se posiciona como el tercer productor mundial de hoja de coca con 40.200 toneladas, el 15,3 por ciento del total. Es por esta razón que Bolivia se ha visto envuelta en este fenómeno transnacional superando así su capacidad individual para hacer frente al narcotráfico.

De acuerdo con el programa internacional para el control de drogas de las Naciones Unidas (UNDCP), los programas de Desarrollo Alternativo son aquellos diseñados para respaldas a países en vías de desarrollo con el fin de eliminar la producción de drogas ilícitas en sus territorios. Dichos programas ayudan a los gobiernos a encontrar y extender estrategias socio económicas alternativas a los campesinos involucrados en la producción de cosechas de insumo de drogas que los gobiernos desean eliminar. Estos programas se iniciaron con la ayuda del gobierno de Estados Unidos en la década de los setenta. De acuerdo con el investigador Fernando Rojas, estos proyectos no tuvieron éxito y generaron una serie de conflictos al crear un gran número de desocupados. En julio de 1991 se firma un convenio bilateral entre Estados Unidos y Bolivia para el fortalecimiento comercial de aquellos productos generados por los programas de sustitución del desarrollo alternativo en el cual se priorizan los programas y proyectos que generen empleos e ingresos a corto plazo. Esta propuesta planteó que las tierras utilizadas para la plantación de coca pasen al poder del estado para crear un parque industrial y de servicios en el uso de mano de obra. No obstante, los programas de desarrollo alternativo vuelven a fracasar produciendo enfrentamientos entre los campesinos y las Fuerzas del estado ${ }^{49}$.

\footnotetext{
${ }^{49}$ Stephanie Marie Antelo Dabdoub "El Narcotráfico en Bolivia - Un estudio comparado del mandato presidencial de Evo Morales Ayma y el periodo neoliberal de 1993 a 2003" Universidad de Palermo Facultad de Ciencias Sociales - Licenciatura en Relaciones Internacionales Tesina de Grado Tesis de Maestría
} 


\section{Capitulo III:}

\section{Estado actual del narcotráfico en Bolivia:}

En enero de 2006, Evo Morales Ayma, líder cocalero y dirigente del partido Movimiento Al Socialismo (MAS), toma posesión como presidente electo de Bolivia. Morales es el primer líder indígena que obtiene más de la mayoría absoluta de los votos (53,7 por ciento) desde la transición a la democracia en 1982. Este acontecimiento trajo consigo el establecimiento de una nueva agenda política la cual constituye un giro en el direccionamiento de la política exterior del país. En este respecto, la diplomacia indígena se ha convertido en el nuevo hilo conductor de la política exterior boliviana.

De acuerdo con Ángela Santamaría, la diplomacia indígena se refiere al conjunto de acciones que realizan los pueblos indígenas y las naciones originarias en el campo de las relaciones internacionales. El ejercicio de esta diplomacia implica las funciones de representación en los espacios internacionales de diálogo y de negociación. Se realiza bajo los principios de defensa de los derechos humanos y los derechos de la naturaleza, a partir de los acuerdos y tratados de cooperación y de la permanente promoción de la solidaridad entre los pueblos. La Diplomacia Indígena apoya la defensa de la soberanía económica, territorial y cultural de las naciones y pueblos indígenas que buscan la autodeterminación sobre los recursos naturales dentro de su territorio, respetando los derechos de la madre tierra y todos los seres que la habitan. En este respecto, se considera a la hoja de coca como el vínculo entre el ser humano y la Pachamama y, es el eje de la interacción de reciprocidad del mundo indígena, por lo tanto es esencial en la cosmovisión andina, y un elemento que acompañó a los pueblos originarios a lo largo de la historia.

De acuerdo con el ministerio de relaciones exteriores y culto, uno de los principales ejes de la política exterior del país es lograr que la comunidad internacional reconozca a la hoja de coca originaria y ancestral como patrimonio cultural y recurso natural renovable de la biodiversidad de Bolivia y como factor de cohesión. Para este fin, el gobierno ha implementado una serie de objetivos: 
- Reivindicar y difundir el carácter histórico y cultural de la hoja de coca en el ámbito nacional e internacional.

- Recopilar, sistematizar y generar investigaciones nacionales e internacionales, que demuestren científicamente los usos benéficos de la hoja de coca y sus derivados.

- Retirar a la hoja de coca de la Lista I de la Convención Única de 1961

- Implementar y fomentar procesos de industrialización, comercialización y exportación de la hoja de coca y sus productos derivados benéficos.

- Revalorizar a la hoja de coca desde el punto de vista ambiental, bajo parámetros de racionalización de cultivos y la preservación de la biodiversidad nativa.

Se puede apreciar que el mayor desafío del gobierno es poder articular la noción de revalorización de la hoja de coca con una reducción del narcotráfico. El discurso presidencial sostiene que la erradicación de la hoja de coca, o coca cero, no es posible por los usos y costumbres existentes en el país; de esta manera el gobierno proclama, nacional e internacionalmente, su lema "coca sí, cocaína no."

Este desafío se convierte en la constante del gobierno de Evo Morales no sólo por la revalorización de la hoja de coca descrita anteriormente, sino también por la influencia del sindicato de cocaleros en la gestión gubernamental. En este respecto, Evo Morales siguió conservando su puesto como dirigente de las Seis Federaciones de Cocaleros del Trópico de Cochabamba. El rol paralelo de Evo Morales como dirigente de los sindicatos cocaleros y presidente del estado plurinacional de Bolivia, es un símbolo de la imbricación que existe entre ambos.

\section{Postura Bolivariana en la lucha contra el Narcotráfico:}

La estrategia de la lucha contra el Narcotráfico y la Revalorización de la Hoja de Coca, emitido por el estado plurinacional de Bolivia, la adopción de medidas neoliberales hasta el 2005, profundizó la situación de pobreza, desempleo y marginación de grandes sectores de la población boliviana, ocasionando altos flujos de migración en búsqueda de alternativas de sobrevivencia. Así, el cultivo de la hoja de coca en la zona del Chapare se convirtió en una alternativa de vida para muchas familias. Entre algunas de las consecuencias de la lucha contra el narcotráfico se enumeran: 
- muertos, heridos, persecuciones, detenidos y violencia

- violación de los derechos humanos

- pérdida de soberanía e injerencia externa

- actos de corrupción

- conflictos sociales e inestabilidad política y económica

- relaciones conflictivas entre las instituciones civiles, policiales y militares

- violación del estado de derecho

- altos costos económicos, políticos y sociales

En este contexto, el gobierno boliviano estableció una nueva estrategia en la lucha contra el narcotráfico la cual plantea:

- La racionalización y control social de la hoja de coca, lo cual implica la reducción de cultivos de coca de manera consensuada y voluntaria con los productores, la definición de áreas de no expansión de cultivos de coca y la erradicación de cultivos en áreas prohibidas, en el marco del pleno respecto a los derechos humanos.

- La reducción progresiva del potencial de producción de cocaína mediante el fortalecimiento de las medidas de control e interdicción.

- El fortalecimiento de las políticas públicas para la implementación de acciones de prevención del consumo de drogas y tratamiento de drogodependientes.

- La responsabilidad compartida de los países para reducir el consumo de droga y apoyar el desarrollo productivo para la generación de empleos e ingresos en las zonas de producción de coca.

En este respecto, la racionalización es un mecanismo de reducción voluntaria y concertada de la producción de hoja de coca entre las organizaciones sociales y el estado. De acuerdo con el ministerio de relaciones exteriores y culto, el control social para la producción de la hoja de coca es una propuesta emergente del movimiento campesino cocalero, por lo tanto aceptado por las organizaciones sindicales y el gobierno bajo criterios de concertación y participación. Así, son los sindicatos de cocaleros quienes tienen la labor de vigilar que no se cultive más de un cato (1.600 metros cuadrados) por familia, para que no haya producción excesiva de coca.

La estrategia de la lucha contra el Narcotráfico y la Revalorización de la Hoja de Coca, apuesta fuertemente por la participación social a través del control comunitario para alcanzar las metas Tesis de Maestría 
de racionalización y de vigilancia de los cultivos de hoja de coca, todo esto bajo responsabilidad de los propios agricultores. Es decir que la racionalización serían acciones concertadas (contratos sociales) con las comunidades para reducir las plantaciones de hoja de coca a través de la implementación de proyectos integrales acordados entre el gobierno y los agricultores.

De acuerdo con Elena Ruiz Labrador, la estrategia del gobierno ha tenido muchas dificultades para garantizar su cumplimiento y un ejemplo de esto fue a principios de 2008 cuando el viceministerio de la hoja de coca emitió la resolución 284 la cual desautorizaba la venta de hoja de coca en Cochabamba y Santa Cruz a los productores asociados a Adepcoca ya que, en primer lugar no habían cumplido con el contrato social de racionalización de cultivos y, en segundo lugar porque no contaban con un registro pormenorizado de quienes comerciaban el producto y a quienes se lo enviaban.

Esta primera disputa concluyó con la anulación de la Resolución 284. En 2008, Evo Morales admitió que en la zona del Trópico de Cochabamba había dirigentes que violaban el cato de coca "lamentablemente no toda nuestra coca va al mercado legal", explicó el propio presidente quien además, le dijo a los cocaleros que si no apoyaban las políticas planteadas por su gobierno, la posible despenalización internacional estaría en peligro. Más aún, de acuerdo con el asambleísta departamental del Chapare, Edgar Torres, más del 50 por ciento de las familias en el chapare tienen una extensión de cultivo de hoja de coca que excede a los 1.600 metros cuadrados.

Este dato pone en evidencia que la estrategia de control social implementada por el gobierno de Evo Morales es más permisiva con los campesinos y cocaleros ya que, comparando con el periodo neoliberal descrito en esta tesina, la reducción voluntaria de cocales no fue una estrategia clave en la lucha contra el narcotráfico y peor aún bajo el control mismo de los sindicatos cocaleros. Durante el periodo neoliberal se dio mayor énfasis al rol de las Fuerzas Armadas para emplear las erradicaciones forzosas y, en este sentido, a partir de la comparación de datos sobre erradicación de cocales excedentarios durante las 3 gestiones se puede apreciar que fue durante el periodo neoliberal (con mayor énfasis durante el gobierno de Bánzer) en que se logró reducir una mayor cantidad de cocales excedentarios en las zonas no tradicionales. A la permisividad aquí descrita, se agrega el factor de influencia de los sindicatos cocaleros en la gestión gubernamental de Evo Morales quien desde 1996 mantiene su cargo de presidente del comité de coordinación de las Seis Federaciones de Cocaleros del Trópico de Cochabamba. Otro aspecto 
que pone en evidencia la mayor permisividad del gobierno actual es la reforma a la ley de sustancias controladas 1008 .

\section{$\underline{\text { Reforma a la ley } 1008}$}

En el marco de la ley 1008, la erradicación aplicada en el pasado buscaba la eliminación de toda la hoja de coca por encima de las 12.000 hectáreas. En cambio, con Evo Morales la producción legal se establece en las 20.000 hectáreas. Cabe destacar que no se conoce un parámetro legal que defina la nueva cantidad de hectáreas de cultivo, fijada en 20 mil hectáreas por el gobierno para el consumo legal de coca; sin embargo, el presidente emitió la resolución ministerial 001/2007 la cual permite las 20 mil hectáreas y, al estar jerárquicamente en contraposición a la Ley 1008, que determina en 12 mil las hectáreas legales, es inconstitucional.

En septiembre de 2008, el gobierno de Bolivia firmó un acuerdo con 25.000 productores de coca de la federación de los Yungas para erradicar 6.900 hectáreas hasta el año 2010. Este acuerdo permitió simultáneamente el cultivo de 6.500 hectáreas adicionales de coca en nuevas áreas dentro y alrededor de los Yungas. En 2009 el gobierno de Bolivia también continuó la política que permite anualmente el cultivo de un cato de coca (entre la sexta y la cuarta parte de una hectárea) por familia productora de coca en la región del Chapare. Esta política ha dado por resultado aproximadamente 7.000 hectáreas adicionales de cultivos de coca.

\section{$\underline{\text { La nacionalización de la lucha contra el narcotráfico }}$}

Uno de los mayores reclamos del sector cocalero en relación a la política antidroga de los gobiernos neoliberales tuvo que ver con la intromisión de Estados Unidos y organismos internacionales, es por esta razón que la nueva estrategia plantea la nacionalización y regionalización en este tema.

En 2008 el mandatario boliviano decidió la suspensión indefinida de cualquier actividad del departamento antidroga de Estados Unidos (DEA) en Bolivia, así, los efectivos de la agencia antidrogas estadounidense que operaban en Bolivia desde 1986, se vieron forzados al repliegue. De esta manera el gobierno ha nacionalizado la lucha contra el narcotráfico mediante el fortalecimiento de las Fuerzas Especiales de Lucha contra el Narcotráfico (FELCN) y la creación de la Unidad Ejecutora de Lucha Integral contra el Narcotráfico (UELIC) para reemplazar las 
actividades de la DEA. A su vez, el Financiamiento de las actividades de interdicción pasaron a ser parte del presupuesto nacional a través del Tesoro General de la Nación y, la formulación de los planes operativos se efectúan sin injerencia de organismos internacionales. En una entrevista con el diario Página Siete de la ciudad de La Paz, el representante de la UNODC en Bolivia César Guedes afirmó que: "Bolivia es el mayor abastecedor de cocaína al mercado sudamericano. "50

Buscando una lucha conjunta contra el narcotráfico los gobiernos de Bolivia y Brasil suscribieron el acuerdo BRABO. Este acuerdo es de vital importancia ya que ambos comparten una frontera de 3.423 kilómetros. De acuerdo con el ex zar antidrogas boliviano, Ernesto Justiniano la política antinarcóticos ha fracasado en Bolivia, la preocupación de los países vecinos sobre el ingreso de esta sustancias ha incrementado y, a esto se suma que los cielos boliviano, carentes de control, se han convertido en una autopista para la cocaína. En este respecto, en Argentina, la Cámara Federal de Salta solicitó en 2009 a la Corte Suprema de Justicia y al Consejo de la Magistratura de la Nación Argentina la instalación de radares en la frontera norte que permitan identificar los vuelos de aeronaves que transportan la droga desde Bolivia” En este marco, los gobiernos de Argentina y Bolivia suscribieron el plan ARBOL el cual tiene como objetivo cerrar el paso a todas las mafias de la droga que operan en zonas fronterizas y, coordinar acciones policiales para el intercambio de información.

Cultivos vs. Erradicación de Hoja de Coca: De acuerdo con el Informe Anual de Monitoreo de Cultivos de Hoja de coca en Bolivia 2009, en los primeros 5 años del gobierno de Evo Morales, los cultivos de hoja de coca aumentaron en 5.500 hectáreas y, la erradicación aumentó en apenas 268 hectáreas. El gráfico demuestra que los cultivos de Hoja de Coca se han mantenido en aumento y las erradicaciones no tuvieron un patrón estable de crecimiento o decremento.

\footnotetext{
${ }^{50}$ Guedes, César (2011, 14 de noviembre) Onu: Bolivia es el mayor abastecedor de cocaína a Brasil, Argentina y Chile. Hoy Bolivia, disponible en la red, consultado el 15 de noviembre de 2011 de : www.hoybolivia.com/noticia.php?IdNoticia=55175\&tit Tesis de Maestría
} 
"Bolivia como nuevo epicentro del Narcotráfico en Sudamérica y su incidencia en Argentina"

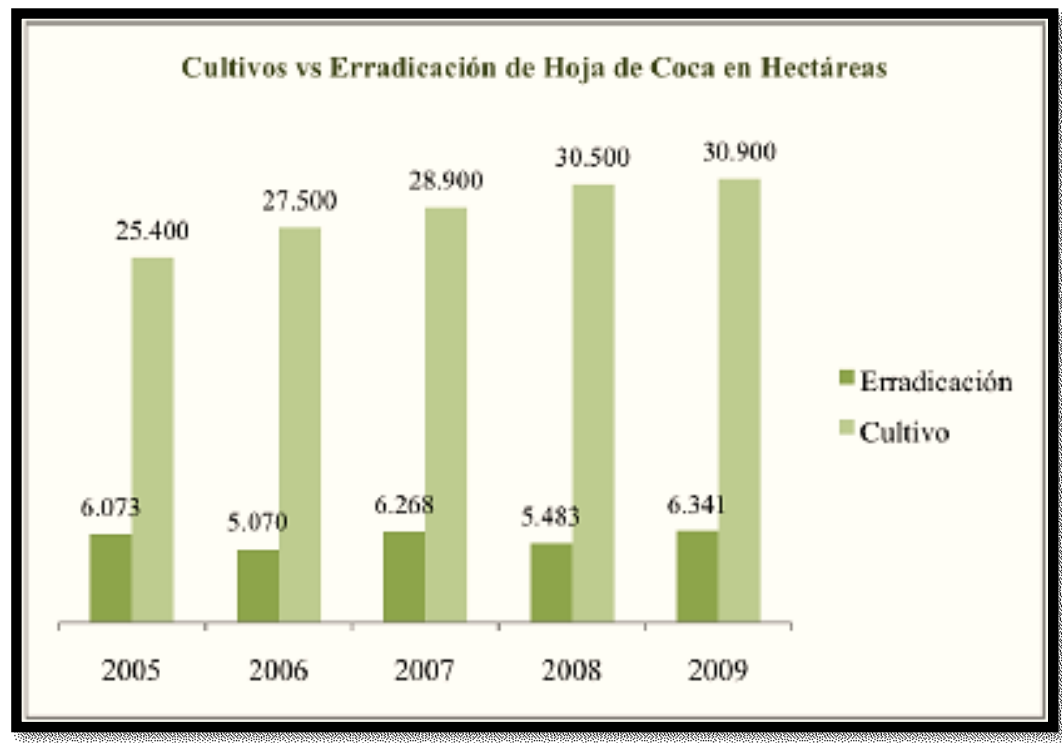

Fuente: Informe Mundial sobre las drogas de las Naciones Unidas 2009, Bolivia cultivo de Hoja de Coca en Hectáreas

$\mathrm{Si}$ comparamos estos resultados con los obtenidos durante las gestiones neoliberales comprendidas entre 1993-2004, se tiene los siguientes resultados expresados en la siguiente tabla:

\begin{tabular}{|c|c|c|}
\hline \multirow{2}{*}{ Año } & \multicolumn{2}{|c|}{ Superficie de Coca cultivada en Bolivia } \\
\hline & Erradicación & Hectáreas Netas \\
\hline 1993 & 2.397 & 47.200 \\
\hline 1994 & 1.058 & 48.100 \\
\hline 1995 & 5.493 & 48.600 \\
\hline 1996 & 7.512 & 48.100 \\
\hline 1997 & 7.826 & 45.800 \\
\hline 1998 & 11.621 & 38.000 \\
\hline 1999 & 15.353 & 21.800 \\
\hline 2000 & 7.653 & 19.600 \\
\hline 2001 & 9.435 & 19.900 \\
\hline 2002 & 11.853 & 24.400 \\
\hline 2003 & 10.087 & 22.800 \\
\hline 2004 & 8.437 & 27.600 \\
\hline 2005 & 6.073 & 25.400 \\
\hline 2006 & 5.070 & 28.000 \\
\hline 2007 & 6.269 & 28.900 \\
\hline 2008 & 5.483 & 30.500 \\
\hline 2009 & 6.341 & 30.900 \\
\hline
\end{tabular}

Fuente: Datos obtenidos por el Centro Latinoamericano para la investigación científica 
El cuadro anterior puede visualizarse en forma de gráfico:

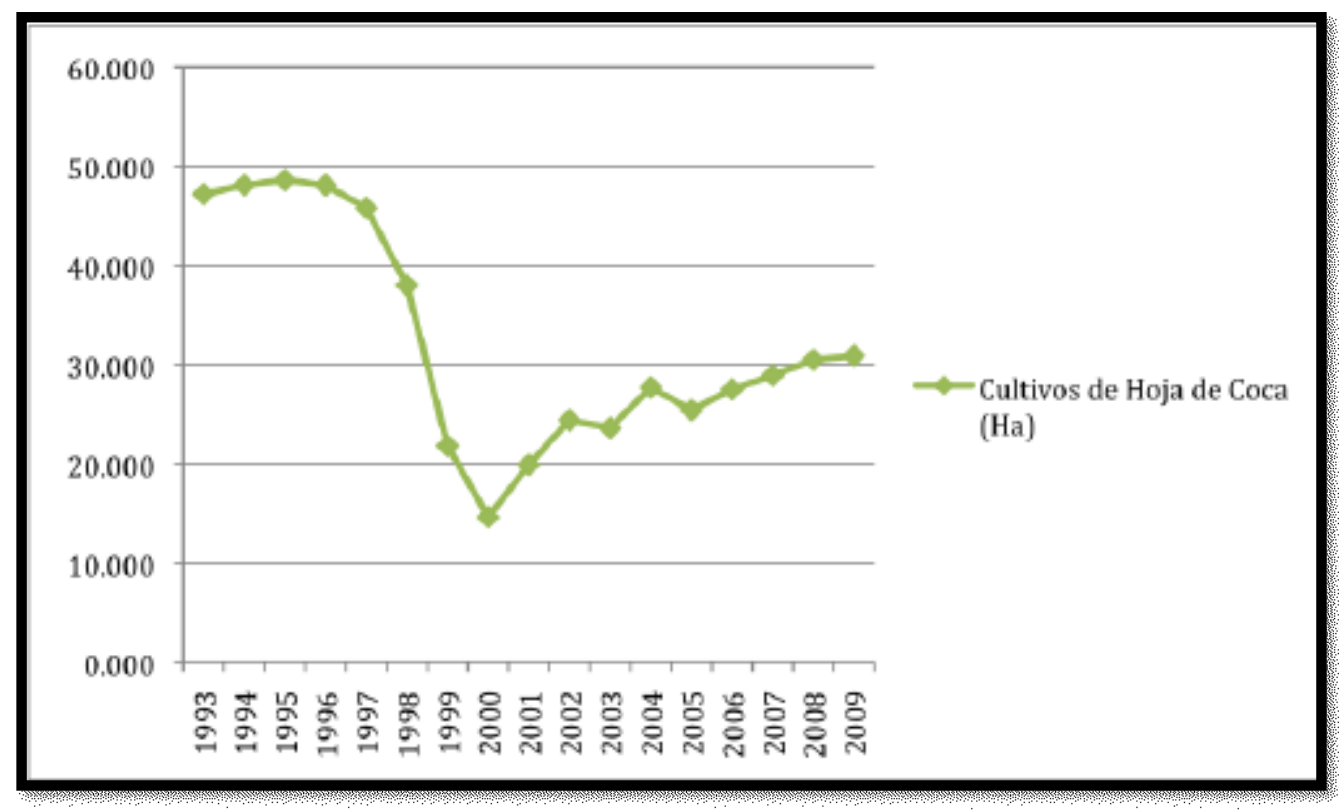

Fuente: Informe Mundial sobre las drogas de las Naciones Unidas 2009, Bolivia cultivo de Hoja de Coca en Hectáreas

El gráfico y la tabla nos muestran la evolución nacional de los cultivos de hoja de coca en los tres periodos comprendidos en esta tesina. Como se puede observar, entre 1997 y 2000 se llevaron a cabo las tareas de erradicación de cocales más exitosas. Dicho periodo corresponde a la administración de Bánzer en la cual también se registró la menor cantidad de hectáreas netas de plantaciones de hoja de coca. De esta manera, se puede afirmar que el gobierno del general Bánzer, con sus políticas de interdicción y un rol preponderante de las Fuerzas Armadas, fue el que más logros consiguió en materia de erradicación. Es notorio el punto situado en el año 2000 ya que en los años que le anteceden ocurre un prolongado descenso de los cultivos el cual, después del 2000 empieza a incrementar. Cómo se mencionó anteriormente, la políticas iniciales de lucha contra el narcotráfico implementadas por Sánchez de Lozada durante 1993-1995 no dieron los resultados esperados, fue a partir de la implementación de una estrategia menos permisiva lo que dio inicio a la disminución efectiva de los cocales excedentarios a partir de 1995.

Con el general Bánzer se batieron todos los records, alcanzando un pico de 19.600 hectáreas de hoja de coca sin embargo, la renuncia de éste por motivos de enfermedad terminal generó un aumento constante de los cocales el cual sólo logró disminuir durante el breve gobierno de Gonzalo Sánchez de Lozada en 2002-2003. Cabe destacar que el periodo posterior al año 2000 
fue un uno de profunda crisis política y social de Bolivia en la cual hubo 4 presidentes en un lapso de 5 años.

Con respecto a la erradicación de cultivos, se aprecia un significativo aumento entre 1994 a 1999. Este incremento de erradicaciones logró establecer el punto histórico de 14.600 hectáreas de hoja de coca. El descenso de erradicaciones de 1999 al año 2000 se explica porque los cultivos se encontraban en su punto más mínimo y por ende, en ese año no hubo necesidad de continuar con las erradicaciones masivas, es más, entre esos años la cantidad de cultivos de hoja de coca disminuyó de 21.800 hectáreas en 1999, a 19.600 hectáreas en el año 2000.

Con respecto a las erradicaciones, según los datos de CELIM, en el periodo que va desde 1986 hasta el 2007 los años en los que se realizó la mayor cantidad de erradicaciones fueron los siguientes:

\begin{tabular}{|c|c|c|c|}
\hline $\begin{array}{c}\text { Cantidad de } \\
\text { Hectáreas } \\
\text { Erradicadas } \\
\end{array}$ & Aino & Presidente & \multirow{6}{*}{$\begin{array}{l}\text { E1 cuadro evidencia que el gobierno que realizó la mayor } \\
\text { cantidad de erradicaciones de hoja de coca excedentaria } \\
\text { fue Hugo Bánzer Suárez en el año } 1999 \text {. Luego le sigue } \\
\text { Gonzalo Sánchez de Lozada con } 11.853 \text { hectáreas en el } \\
2002 \text {. En este contexto, queda demostrado que durante los } \\
\text { gobiernos neoliberales de Lozada y Bánzer se llevó a cabo } \\
\text { la mayor cantidad de erradicaciones en Bolivia. }\end{array}$} \\
\hline 15.353 & 1999 & Bánzer & \\
\hline 11.853 & 2002 & Lozada & \\
\hline 11.621 & 1998 & Bánzer & \\
\hline 10.087 & 2003 & Lozada & \\
\hline 9.435 & 2001 & Lozada & \\
\hline
\end{tabular}

Por otro lado, el promedio de erradicaciones durante la gestión gubernamental de Evo Morales es de 5.847 hectáreas, con Gonzalo Sánchez fue de 6.604 hectáreas y, finalmente con Bánzer fueron 10.378 hectáreas. Esto demuestra que durante los gobiernos neoliberales se llevó a cabo la mayor cantidad de erradicaciones en Bolivia.

El último informe mundial sobre las drogas sostiene que en tanto que los traficantes colombianos han producido la mayor parte de la cocaína del mundo en los últimos años, de 2000 a 2009 la superficie dedicada al cultivo de coca en Colombia se redujo en un 58\%, principalmente debido a su erradicación. Paralelamente, el cultivo de coca aumentó en un 38\% en el Perú y se duplicó con creces en el Estado Plurinacional de Bolivia (hasta un 112\%), mientras que los traficantes en ambos países aumentaron su propia capacidad para producir cocaína. 


\section{Producción potencial de Cocaína ${ }^{51}$}

En relación a la capacidad de producción potencial de cocaína, La Junta Internacional de Fiscalización de Estupefacientes (JIFE) adscrita a la Organización de Naciones Unidas, determinó que la producción potencial de cocaína en Bolivia alcanzó a 120 toneladas métricas en 2008, manteniendo un aumento constante durante los primeros cuatro años del gobierno del MAS. Esto significa que en el año 2008 se evidenció un incremento del 50\% de producción potencial de cocaína ya que se ha pasado de 80 toneladas de cocaína producidas en el 2005 a 120 toneladas en el 2008.

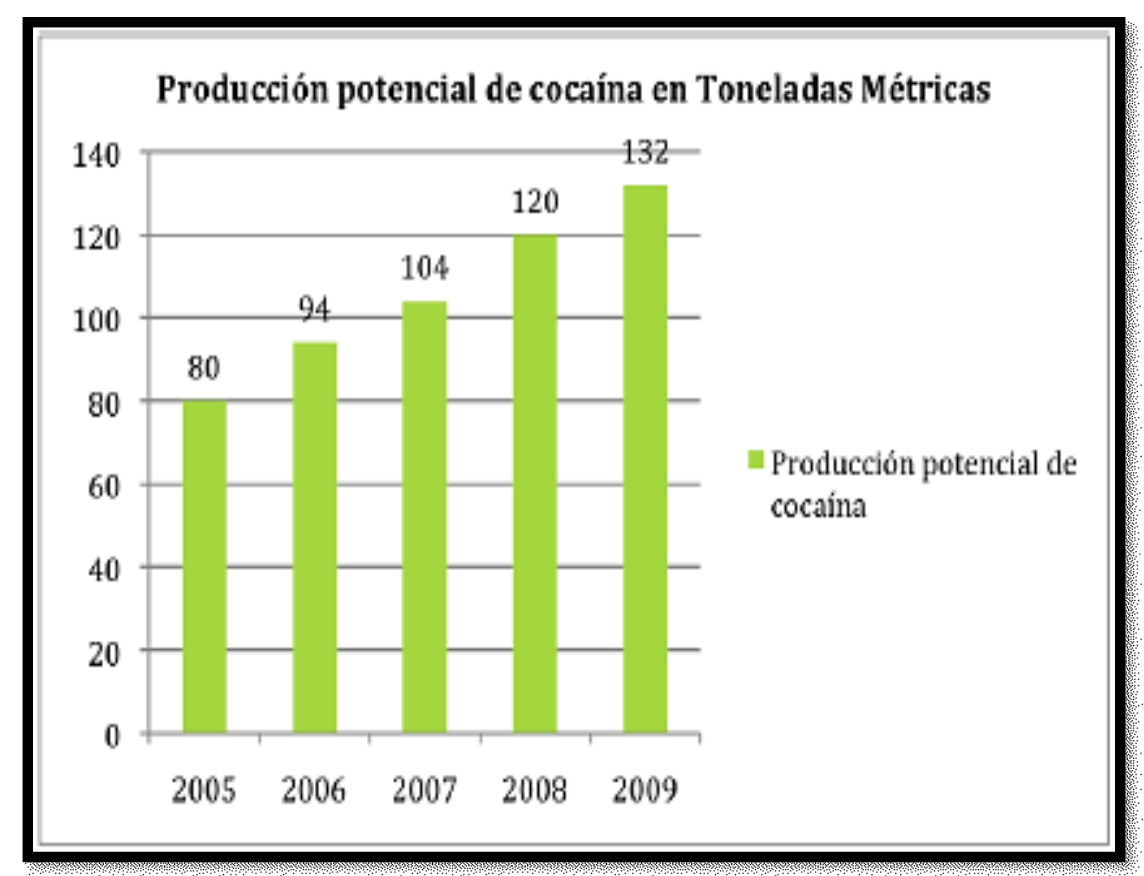

Datos obtenidos de la UNODC, Estado Plurinacional de Bolivia, monitoreo de hojas de coca 2009

El cuadro superior demuestra que durante la gestión gubernamental de Evo Morales, el aumento en la producción potencial de cocaína ha sido constante. Comparando estos datos con el periodo neoliberal, se tiene los siguientes resultados:

\footnotetext{
${ }^{51}$ Stephanie Marie Antelo Dabdoub "El Narcotráfico en Bolivia - Un estudio comparado del mandato presidencial de Evo Morales Ayma y el periodo neoliberal de 1993 a 2003" Universidad de Palermo Facultad de Ciencias Sociales - Licenciatura en Relaciones Internacionales Tesina de Grado Tesis de Maestría
} 


\begin{tabular}{||c|c|}
\hline \multirow{2}{*}{ Año } & $\begin{array}{c}\text { Producción potencia de } \\
\text { cocaína en Bolivia }\end{array}$ \\
\cline { 2 - 2 } & Toneladas Métricas \\
\hline 1993 & 240 \\
\hline 1994 & 255 \\
\hline 1995 & 240 \\
\hline 1996 & 215 \\
\hline 1997 & 200 \\
\hline 1998 & 150 \\
\hline 1999 & 70 \\
\hline 2000 & 43 \\
\hline 2001 & 60 \\
\hline 2002 & 60 \\
\hline 2003 & 79 \\
\hline 2004 & 107 \\
\hline 2005 & 80 \\
\hline 2006 & 120 \\
\hline
\end{tabular}

Al igual que los resultado obtenidos con la cantidad de erradicaciones, fue durante el gobiemo de Bánzer en que se produjo la menor cantidad de cocaina.

El periodo comprendido entre $1994 \mathrm{y}$ 2000 fueron los más exitosos en cuanto a reducción de la producción potencial de cocaina ya que se logra una disminución del 400 por ciento. A partir de entonces, se registra un aumento constante hasta la actualidad.

Sin embargo, al finalizar el periodo neoliberal (iniciado en $1993 \mathrm{y}$ finalizado en 2003) se puede afirmar que ambos gobiemos lograron rechucir el potencial de producción.

Con Evo Morales el panorama es distinto ya que en ningin momento de su administración se ha registrado una disminución; de acuerdo a estos datos, todo indica que la producción potencial de cocaina se mantendrá en aumento.

Datos obtenidos por el Centro Latinoamericano para la investigación científica

\section{Demografía de la hoja de coca}

El cultivo de la hoja de coca en Bolivia no es un fenómeno extendido a todo el país. La producción está centrada en dos grandes regiones: en los Yungas y en el Chapare. Los Yungas se encuentran en el departamento de La Paz, en la parte oriental de la cordillera de los Andes. La actividad agropecuaria en esta zona está fuertemente marcada por las características de su topografía, bosques secos templados, con escasas zonas planas. Esto dificulta el establecimiento de la agricultura mecanizada.

De acuerdo con la información obtenida en el censo de 2001, Yungas es una zona predominantemente aimara donde el 46,3 por ciento de las familias rurales tienen cultivos de coca, localizados sobre todo en la provincia de Sur Yungas, donde está alrededor del 56 por Tesis de Maestría 
ciento de los cultivos, y Nor Yungas con el 31 por ciento; el 13 por ciento restante corresponde a las regiones de Carnavi, Inquisivi y Murillo26. Estas han sido las zonas tradicionales de producción de hoja de coca ${ }^{52}$.

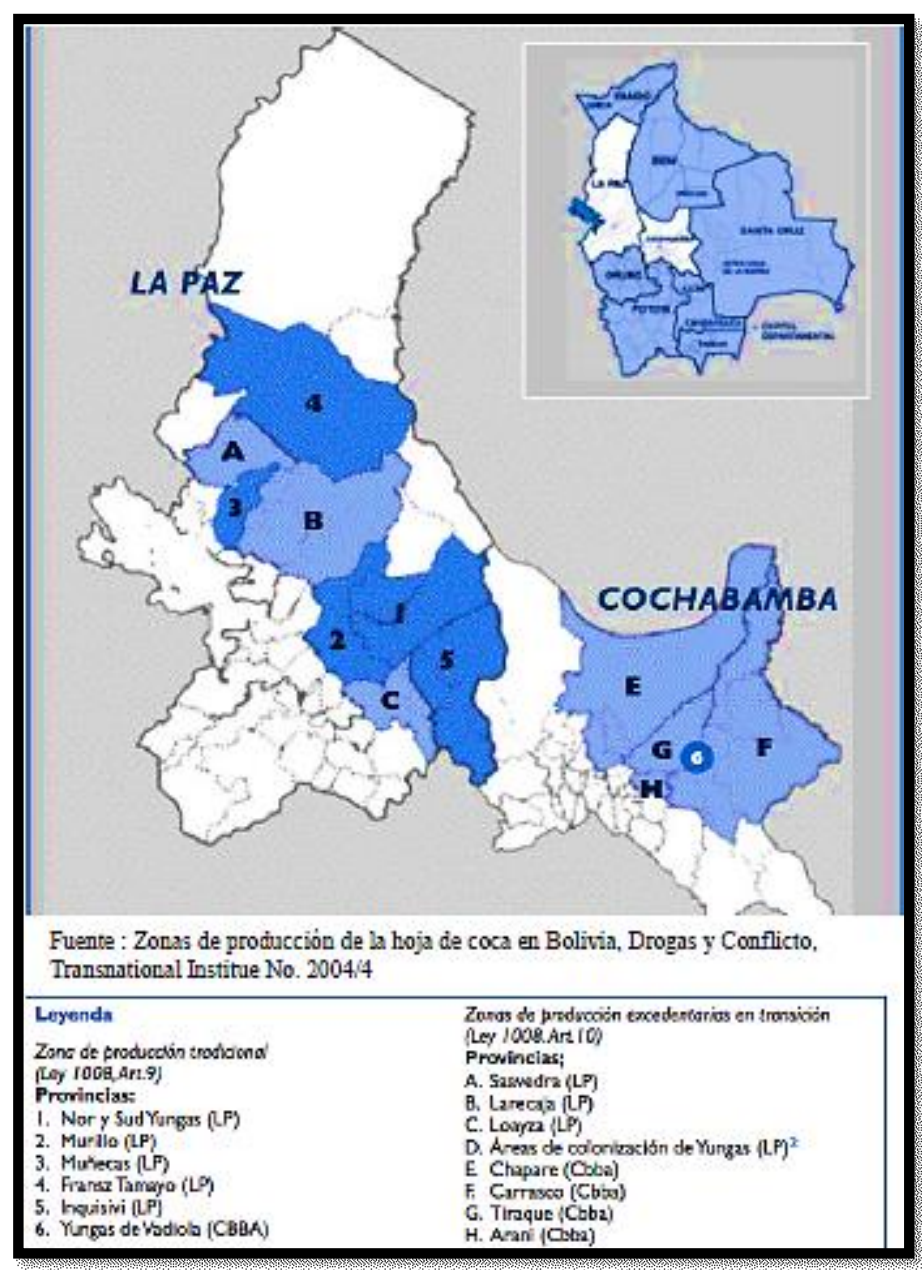

Por otro lado, el Chapare se sitúa en las zonas bajas del departamento de Cochabamba. Se trata de un valle más bajo, húmedo y caluroso que Los Yungas. La mayor parte de la población del Chapare está formada por campesinos migrantes desde los valles y serranías del mismo departamento y de otros departamentos como Oruro, Potosí, Chuquisaca y La $\mathrm{Paz}^{53}$. De acuerdo con Sarká Malá, en el transcurso de la historia colonial y republicana, el Chapare ha vivido diversas olas de inmigración. La colonización moderna, es decir, la que ha supuesto el establecimiento definitivo de sus pobladores, fue realizada en diversas etapas. Ella comenzó en los años 1920 con la construcción de la primera ruta hacia las tierras bajas del noreste del

\footnotetext{
${ }^{52}$ Imagen: Zonas de producción de la hoja de coca en Bolivia, Drogas y Conflicto, Transnational Institute Briefing series No. 2004/4. Recuperado de http://www.tni.org/sites/www.tni.org/files/download/debate10s.pdf

${ }^{53}$ Berniola González, Susana. El conflicto cocalero en Bolivia como resultado del imperialismo estadounidense. Nómada : revista crítica de ciencias sociales y jurídicas. Publicación Electrónica de la Universidad Complutense | ISSN 1578-6730 disponible en la red, consultado el 14 de abril de 2011 de http://www.ucm.es/info/nomadas/17/susanaberniola.pdf Tesis de Maestría
} 
departamento de Cochabamba. Luego, en 1953, en el marco de la reforma agraria, las promesas gubernamentales atrajeron nuevos colonos. En los años setenta, el incremento de la demanda de la industria de la cocaína provoco un aumento importante de la producción de la coca en el Chapare y, con ella se inició una nueva ola de inmigración. El autor agrega que la última ola de inmigración hacia el Chapare está ligada al boom de la coca que se produjo al comienzo de la década de los ochenta.

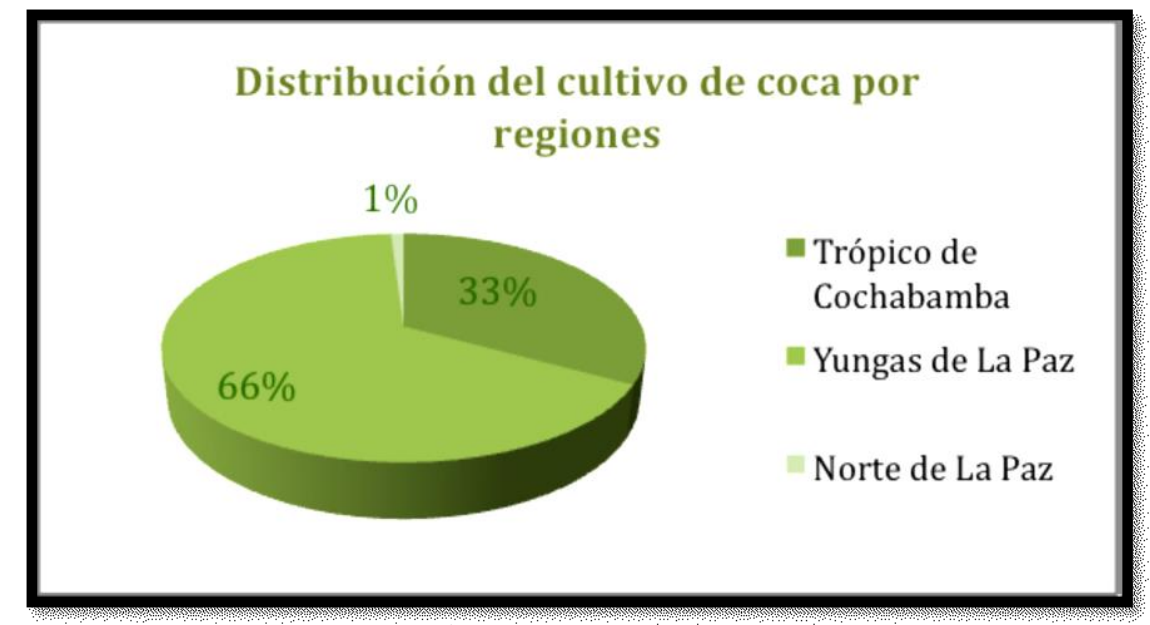

Fuente: Informe Mundial sobre las drogas de las Naciones Unidas 2010, Bolivia cultivo de Hoja de Coca en Hectáreas

Es importante remarcar que la producción de hoja de coca se hace en parcelas pequeñas, según Herbert Klein ${ }^{54}$ de seis o menos hectáreas. Es así que la base de la industria de la cocaína sigue formada por miles de pequeños productores campesinos, organizados familiarmente y con reducidas extensiones de tierra a su disposición.

Los sindicatos que agrupan a los cocaleros están compuestos por pequeños agricultores para los cuales la hoja de coca representa un sustento básico de su economía. Los cocaleros organizados en pequeños sindicatos que pertenecen a la Confederación Sindical Única de Trabajadores Campesinos de Bolivia (CSUTCB) empiezan a organizarse a fines de la década de los setenta para defender su modo de vida. Esta defensa tiene dos pilares básicos: por un lado se pretende mantener los ingresos generados por la producción de hoja de coca, por lo tanto es un motivo económico, pero por otro lado, está la defensa de la cultura tradicional andina representada en el cultivo y consumo de la hoja de coca, que en esta región tiene más de 3000 años. Con respecto a este último punto, cabe destacar que el uso de la hoja de coca para fines tradicionales se encuentra amparado en la legislación boliviana desde 1988. En dicho año ostentaba el mando presidencial Víctor Paz Estensoro, cuyo ministro de economía era Gonzalo Sánchez de Lozada. Con respecto al narcotráfico, la política boliviana en ese periodo giró en torno a la aprobación y

\footnotetext{
${ }^{54}$ Klein, Herbert S. Historia de Bolivia. 8 o ed. Juventud. La Paz. 1999. Pág: 281 Tesis de Maestría
} 
realización de la ley de coca y sustancias controladas, conocida también como la ley 1008. Fue tras la implementación de esta ley que en 1988 Evo Morales fue electo secretario ejecutivo de la Federación del Trópico en Cochabamba, sindicato que aglutinó las luchas campesinas contra la erradicación de la hoja de coca a partir de esta ley.

Este reglamento dispone que el cultivo de la coca es una actividad agrícola cultural, orientada tradicionalmente en forma lícita hacia el consumo, uso en la medicina y rituales de los pueblos andinos. Además, establece una diferencia esencial entre la coca en estado natural, que no produce efectos nocivos a la salud humana, y la coca inter criminis, que es la hoja en proceso de transformación química, que aísla el alcaloide en cocaína y que produce efectos psicológicos y biológicos nocivos para la salud humana.

Según el artículo 15, la producción, circulación y comercialización de la coca quedan sujetas a la fiscalización del Estado a través del órgano competente del Poder Ejecutivo. Posteriormente, se agrega que es responsabilidad del Poder Ejecutivo conocer el origen y destino de la producción de coca así como definir las rutas y medios de transporte para su traslado a los mercados legales de consumo, para lo cual dicho órgano establecerá un sistema de permisos y controles tanto para productores como para transportistas y comerciantes. Toda violación a la presente disposición convertirá a la coca en ilegal ${ }^{55}$

En cuanto a las medidas adoptadas para delimitar las áreas de producción y cultivo de la coca, la ley 1008 establece 12 mil hectáreas para cubrir el mercado legal tradicional. Es decir que, con este reglamento, Bolivia tiene definidas 3 zonas:

\section{Zonas de Producción Tradicional}

La zona de producción tradicional de coca es aquella donde histórica, social y agroecológicamente se ha cultivado coca, la misma que ha servido para los usos tradicionales. En esta zona se producirán exclusivamente los volúmenes necesarios para atender la demanda para el consumo y usos lícitos; comprende las áreas de los sub trópicos de las provincias Nor y Sud Yungas, Murillo, Muñecas, Franz Tamayo e Inquisivi del Departamento de La Paz y los Yungas de Vandiola, que comprende parte de las provincias de Tiraque y Carrasco del departamento de Cochabamba.

\footnotetext{
${ }^{55}$ Ley 1008 del régimen de coca y sustancias controladas, artículo 19, aprobada el 19 de julio de 1988. La Paz, Bolivia Tesis de Maestría
} 


\section{Zonas de Producción Excedentaria en Transición}

Es aquella donde el cultivo de coca es resultado de un proceso de colonización espontánea o dirigida, que ha sustentado la expansión de cultivos excedentarios en el crecimiento de la demanda para usos ilícitos. Esta zona está sujeta a planes anuales de reducción, sustitución y desarrollo mediante la aplicación del Programa Integral de Desarrollo y Sustitución (PIDYS). Dicho programa está condicionado por la disponibilidad de recursos financieros del presupuesto nacional, así como por compromiso y desembolsos de la cooperación técnica y financiera bilateral y multilateral suficiente, que deberá orientarse al Desarrollo Alternativo. Comprende las provincias Saavedra, Larecaja y Loayza, las áreas de colonización de Yungas del departamento de La Paz y las provincias Chapare, Carrasco, Tiraque y Arani del departamento de Cochabamba. Estas zonas están sujetas a planes voluntarios de reducción de cocales ilícitos y a la sustitución de éstos mediante programas de desarrollo alternativo. Además, mediante ese artículo se dio paso a las compensaciones económicas con los campesinos por erradicaciones. El mismo artículo agrega que en otras zonas del territorio de la República queda prohibido el cultivo de coca y si éste se da, la erradicación será obligatoria y sin ningún tipo de compensación.

\section{Zonas de Producción Ilícita}

La zona de producción ilícita de coca está constituida por aquellas áreas donde queda prohibido el cultivo de coca. Comprende todo el territorio de la República, excepto los territorios mencionados en las zonas tradicionales y excedentarias ${ }^{56}$.

\section{Monitoreo de la hoja de coca en Bolivia $^{57}$ : ÁREAS DE MONITOREO Y CARACTERIZACIÓN DEL CULTIVO DE COCA EN BOLIVIA}

Consideramos de importancia hacer nuevamente mención a la delimitación de las áreas de monitoreo de los cultivos de coca se ha establecido inicialmente sobre la base de la Ley $\mathrm{N}^{\circ} 1008$, que define tres zonas de producción de cultivos de coca en Bolivia: 1) zona tradicional, 2) zona excedentaria en transición y 3) zona ilícita. La zona tradicional comprende las provincias Nor Yungas, Sud Yungas, Murillo, Muñecas, Franz Tamayo e Inquisivi del Departamento de La Paz,

\footnotetext{
${ }^{56}$ Stephanie Marie Antelo Dabdoub "El Narcotráfico en Bolivia - Un estudio comparado del mandato presidencial de Evo Morales Ayma y el periodo neoliberal de 1993 a 2003" Universidad de Palermo Facultad de Ciencias Sociales - Licenciatura en Relaciones Internacionales Tesina de Grado

${ }^{57} \mathrm{https} / / /$ www.unodc.org/documents/crop-monitoring/Bolivia/Bolivia_Informe_Monitoreo_Cultivos_Coca_2015.pdf Tesis de Maestría
} 
y las Yungas de Vandiola, que a su vez incluye las provincias Tiraque y Carrasco del Departamento de Cochabamba. La zona de producción excedentaria en transición comprende las provincias Saavedra, Larecaja y Loayza, las áreas de colonización de los Yungas del Departamento de La Paz y las provincias Chapare, Carrasco, Tiraque y Araní del Departamento de Cochabamba. La zona de producción ilícita comprende todo el territorio del Estado Plurinacional de Bolivia, excepto las mencionadas anteriormente.

Esta ley establece que la superficie máxima de cultivos de coca para estas zonas es de 12.000 ha. En el plan de la Estrategia de Lucha Contra el Narcotráfico y Reducción de Cultivos Excedentarios de Coca 2011 - 2015 (ELCNyRCEC), se plantea estabilizar la superficie de cultivos de coca a 20.000 ha.

Provincias donde el cultivo de coca es tradicional y excedentario en transición de acuerdo con la Ley 1008

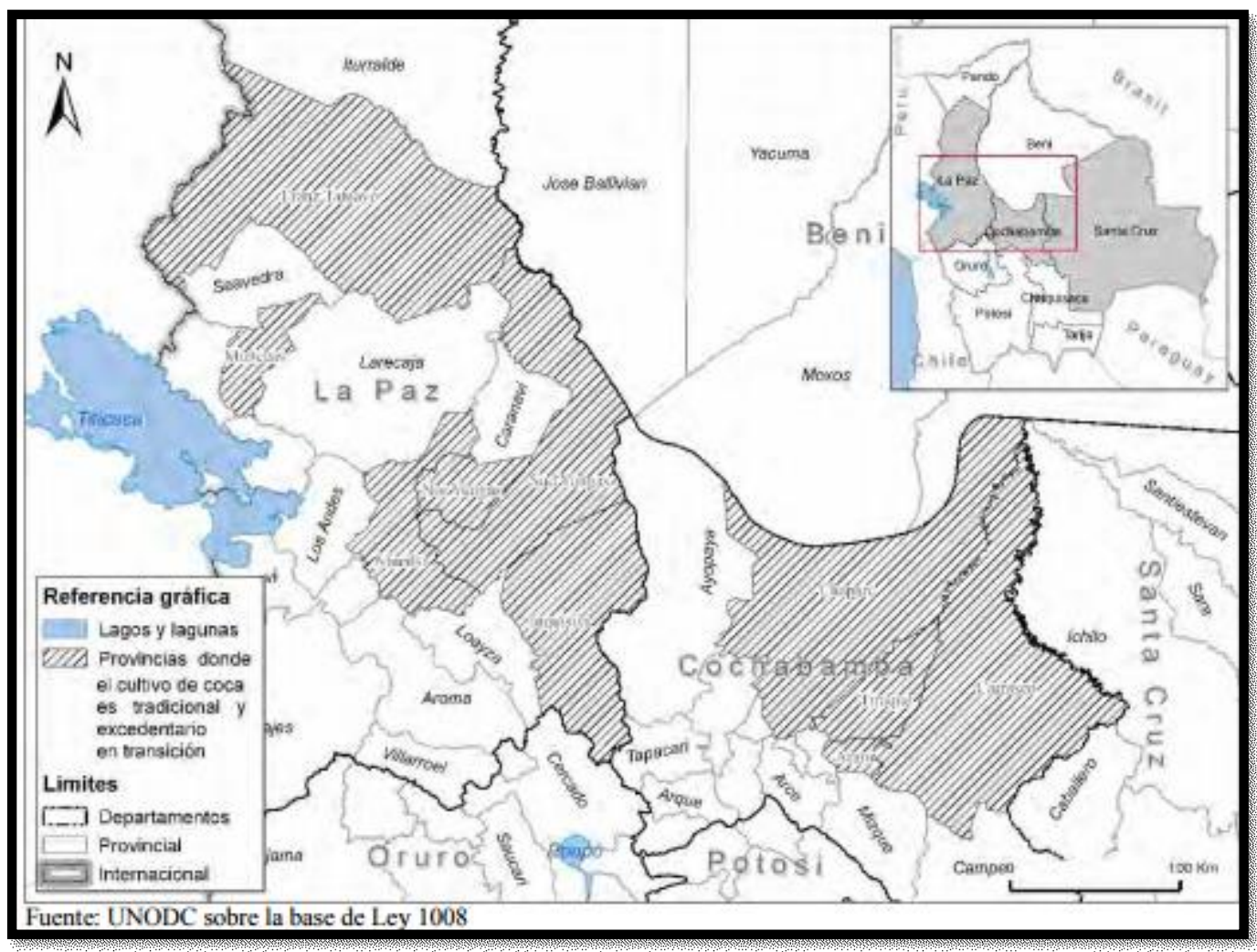

Como resultado de la evolución histórica de los cultivos de coca en Bolivia, se ha determinado que las áreas de monitoreo de cultivos de coca son los Yungas de La Paz, provincias del Norte de La Paz y el Trópico de Cochabamba: 
Maestría en Inteligencia Estratégica Siglo XXI $\mid 79$

"Bolivia como nuevo epicentro del Narcotráfico en Sudamérica y su incidencia en Argentina"

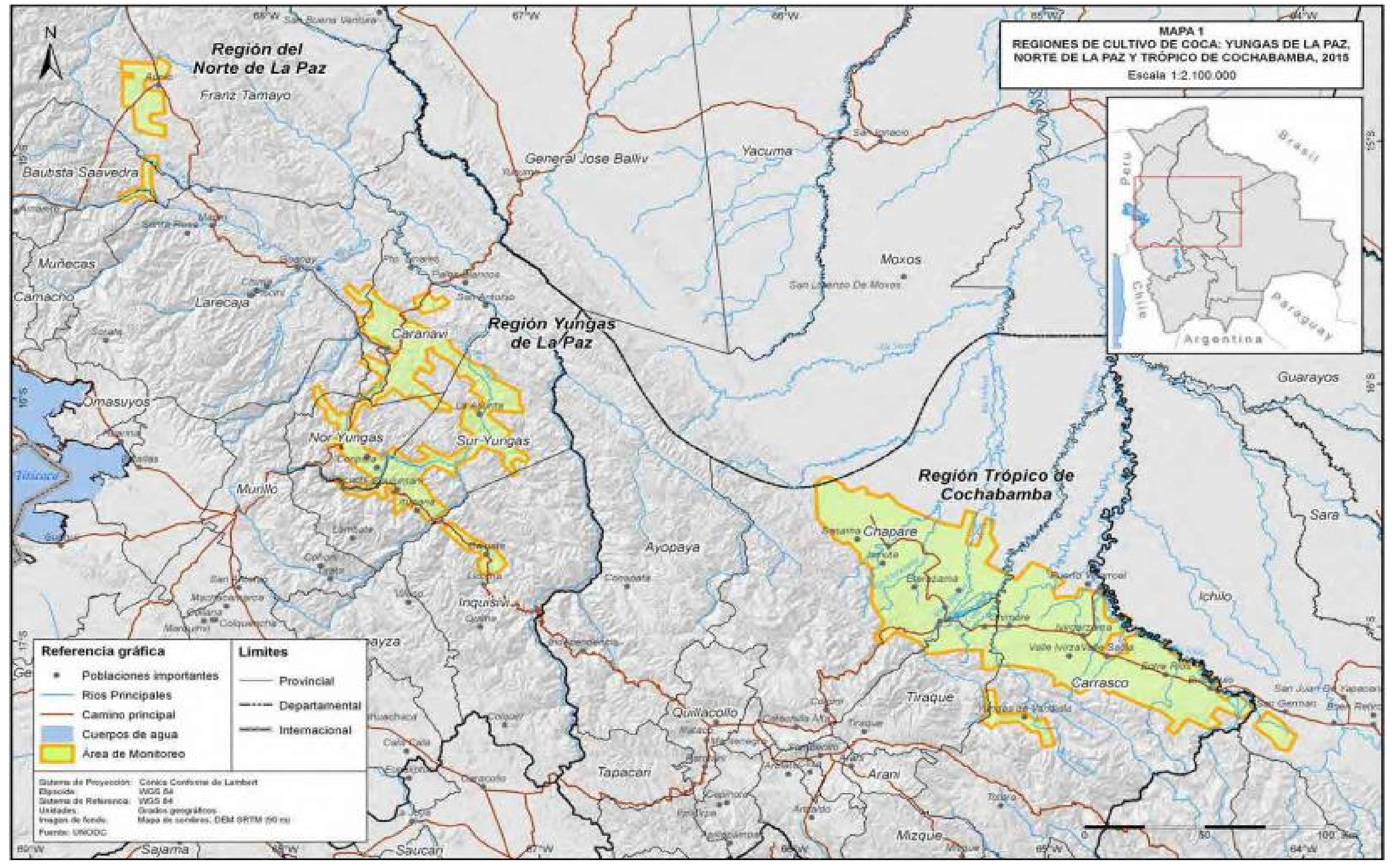

Tesis de Maestría 


\section{Región de los Yungas de La Paz:}

Los Yungas de La Paz comprenden zonas con relieve topográfico irregular, pendientes pronunciadas, valles profundos, ríos caudalosos y elevaciones que varían desde los 300 a 4.000 msnm. Esta región se caracteriza por ser húmeda con nieblas frecuentes y precipitaciones abundantes, comprende climas meso-térmicos o templados, con invierno seco y cálido. En determinadas zonas la vegetación es exuberante y es considerada una región rica en especies animales y vegetales.

La región de monitoreo de cultivos de coca en los Yungas de la Paz abarca 6 provincias: Sud Yungas, Nor Yungas, Caranavi, Inquisivi, Murillo y Larecaja. El Municipio de La Asunta ubicado en la Provincia Sud Yungas es la principal zona productora de coca de los Yungas de La Paz. Otros cultivos están con niveles de producción más bajos y muchos de ellos se utilizan para el consumo local.

La mayor superficie de producción de café se encuentra en la parte central y sur de la Provincia Caranavi. En las provincias Nor Yungas y parte de Sud Yungas, las áreas con cultivos de desarrollo integral son menores que en la Provincia Caranavi.

La producción agrícola varía de acuerdo a las diferentes condiciones ambientales. En general, el cultivo de coca es predominante en la región de los Yungas de La Paz. La mayor superficie de cultivos de coca se sitúa en las provincias Sud Yungas y Nor Yungas, abarcando el 66\% y 22\% de la superficie total en esta región.

En base a misiones de campo y al análisis del Modelo Digital de Elevación (MDE) se ha observado que los cultivos de coca en la región de los Yungas de La Paz por lo general se desarrollan en un rango de altitud de 600 a $2.000 \mathrm{msnm}$ 
Región de monitoreo en los Yungas de La Paz

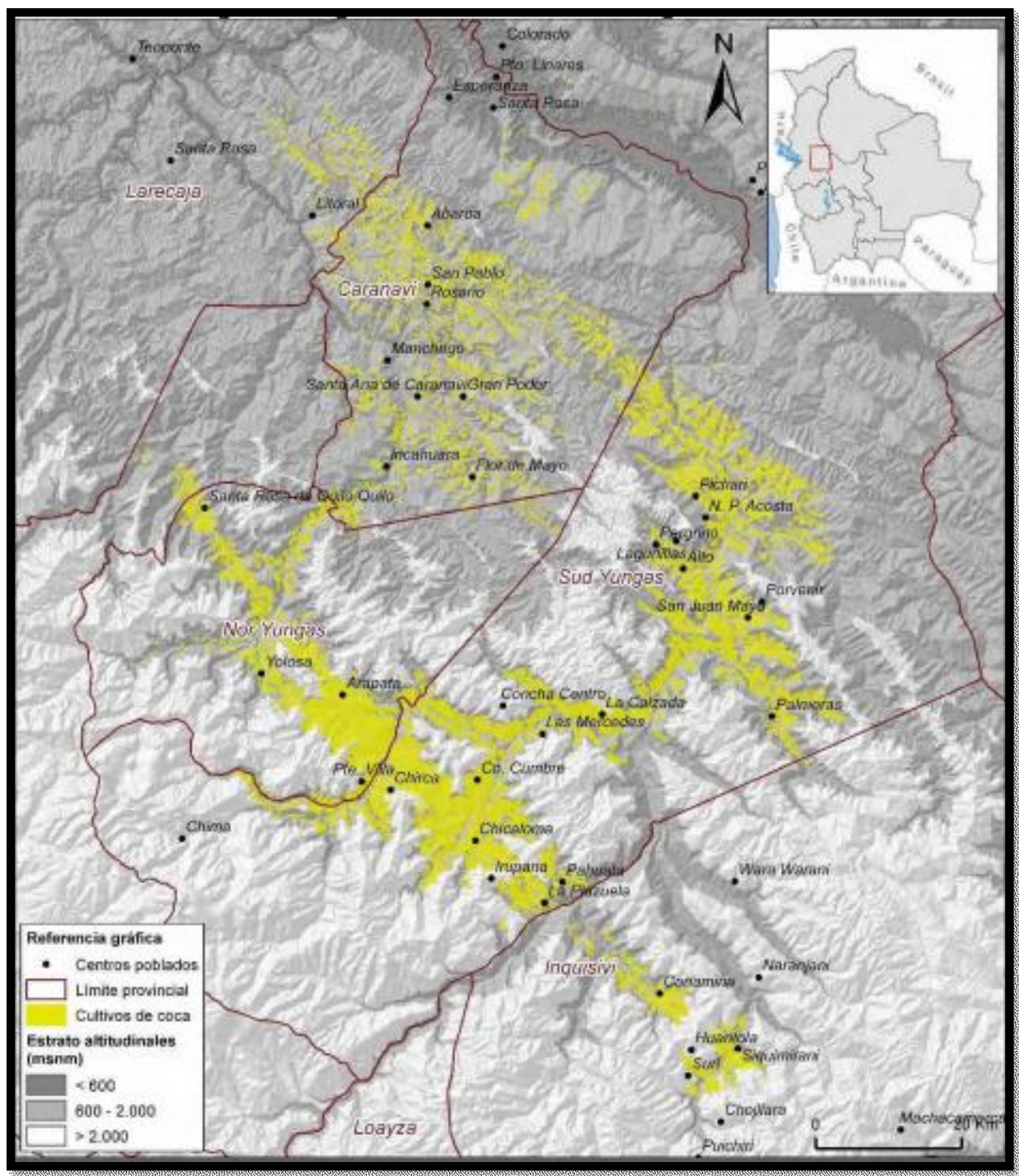

\section{$\underline{\text { Región de las provincias del Norte de La Paz }}$}

A partir de 2009, la UNODC realiza un seguimiento anual a los cultivos de coca en la región tropical de las cuencas de los ríos Camata y Yuyo, (el río Camata es el límite natural entre las provincias Muñecas y Bautista Saavedra). La Provincia Franz Tamayo, Municipio de Apolo es una región que cuenta con la mayor diversidad de pisos ecológicos de toda Bolivia. Comprende dos regiones fisiográficas una tropical y otra montañosa, su clima varía de frio a templado y cálido, caracterizada por su alta diversidad ecológica. Parte de esta provincia se encuentra dentro el Parque Nacional y Área Natural de Manejo Integrado Madidi. Una pequeña área al Sureste de esta provincia está dentro de la Reserva de la Biósfera y Territorio Indígena Pilón Lajas. Las actividades productivas son principalmente la agricultura y ganadería. 
La región de monitoreo de cultivos de coca en el Norte de la Paz abarca 3 provincias: Franz Tamayo, Muñecas y Bautista Saavedra.

Las provincias Bautista Saavedra y Muñecas se caracterizan por presentar relieves topográficos con pendientes pronunciadas similares a la región de los Yungas de La Paz. En base a misiones de campo y al análisis del Modelo Digital de Elevación (MDE) se ha podido observar que los cultivos de coca en la región del Norte de La Paz se desarrollan en un rango de altitud de 800 a $1.800 \mathrm{msnm}$

Región de monitoreo en las provincias del Norte de La Paz

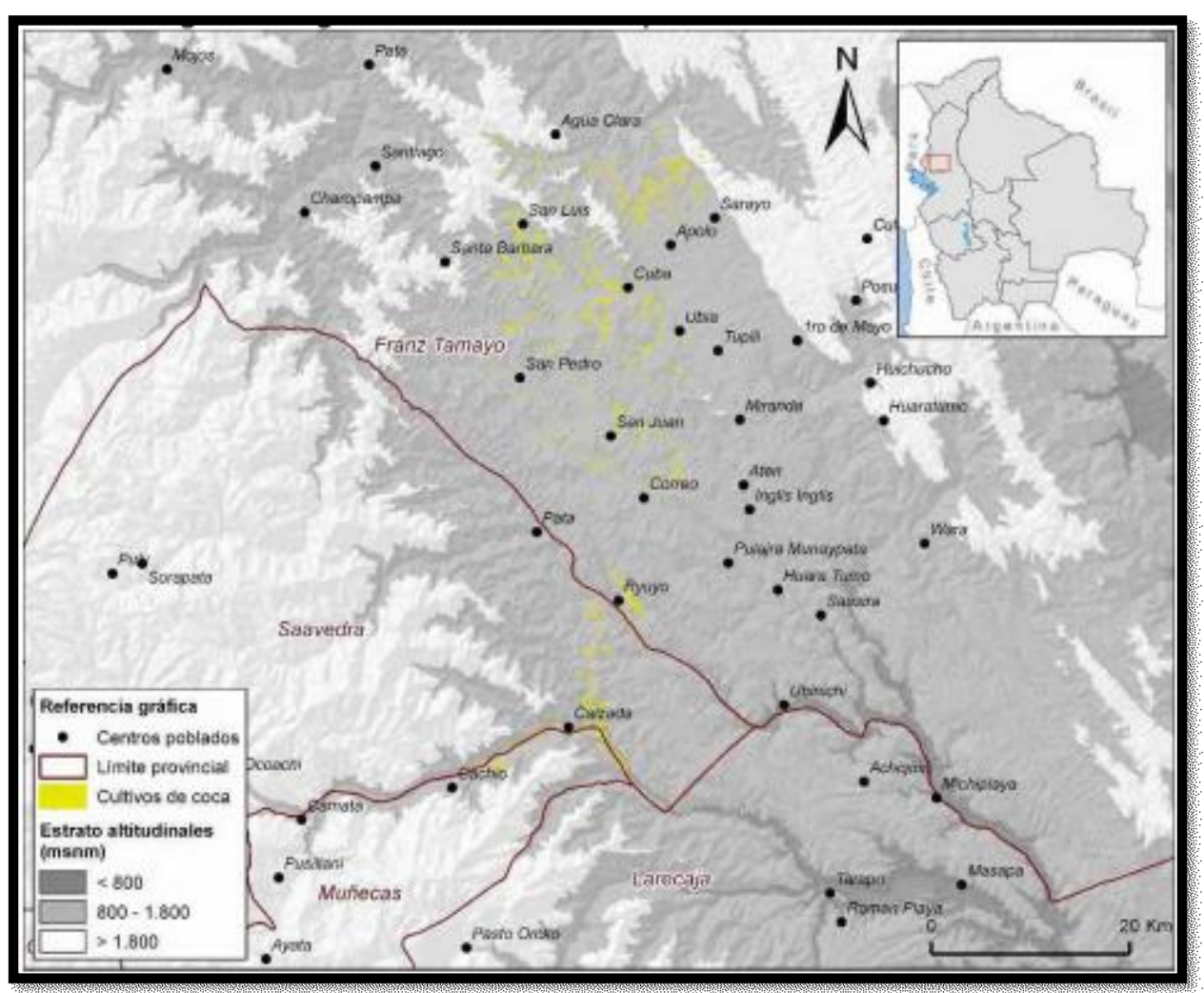

El cultivo de coca en la Provincia Franz Tamayo se establece en valles y colinas bajas; no se utilizan técnicas de laboreo en terrazas. Sin embargo, en las provincias Bautista Saavedra y Muñecas las técnicas de manejo del cultivo y de secado de la hoja de coca son similares a las empleadas en los Yungas de La Paz. 


\section{$\underline{\text { Región del Trópico de Cochabamba }}$}

Entre la cordillera de Los Andes y las Llanuras Amazónicas se encuentra la región del Trópico de Cochabamba abarcando áreas de fisiografía diferenciada: serranías, colinas bajas y pie de monte, para concluir en grandes sabanas tropicales de llanuras aluviales y de inundación hacia el Norte. Los ríos son de cauce ancho y gran caudal, las elevaciones varían de 200 a 2.500 msnm; los cauces principales son el río Sécure, Ichilo, Chapare e Isiboro. Además de estos cuatro ríos corren por la llanura numerosas corrientes secundarias, entre otros los ríos Eterazama, Coni, Chipiriri y Chimoré

El clima de esta región corresponde a las categorías subtropical y tropical con una alta precipitación pluvial que varía desde 1.000 a más de $5.000 \mathrm{~mm}$ anuales. La temperatura promedio es de $25^{\circ} \mathrm{C}$, en periodo lluvioso alcanza temperaturas mayores a los $28^{\circ} \mathrm{C}$, con índices elevados de humedad. Este hecho favorece el desarrollo de una vegetación densa que alberga una gran variedad de especies de árboles, arbustos, enredaderas y otras plantas. En esta región existen varios cultivos que diversifican la producción agrícola de la zona, como son las plantaciones de banano, cítricos, piña, palmito, maracuyá, yuca, arroz, té, entre otros, cuya producción en algunos casos alcanza niveles industriales destinados a la comercialización y exportación. Esta región cuenta con una amplia red de caminos secundarios empedrados, situación que facilita el transporte de estos productos a los mercados nacionales e internacionales.

La región de monitoreo de cultivos de coca del Trópico de Cochabamba está conformada por las provincias Chapare, Tiraque y Carrasco del Departamento de Cochabamba y la Provincia Ichilo perteneciente al Departamento de Santa Cruz. En esta región se encuentran los Parques Nacionales Isiboro Sécure al Noroeste, Carrasco al Sur y Amboró al Sureste del área de monitoreo.

Esta región de monitoreo cubre una superficie aproximada de $8.000 \mathrm{~km}^{2}$. El control de plantaciones de coca excedentaria en esta región es complejo, debido a la alta dinámica de los cultivos de coca. En base a misiones de campo y al análisis del Modelo Digital de Elevación (MDE) se ha podido observar que los cultivos de coca en la región del Trópico de Cochabamba se desarrollan en un rango de altitud de 200 a $1.500 \mathrm{msnm}$. 


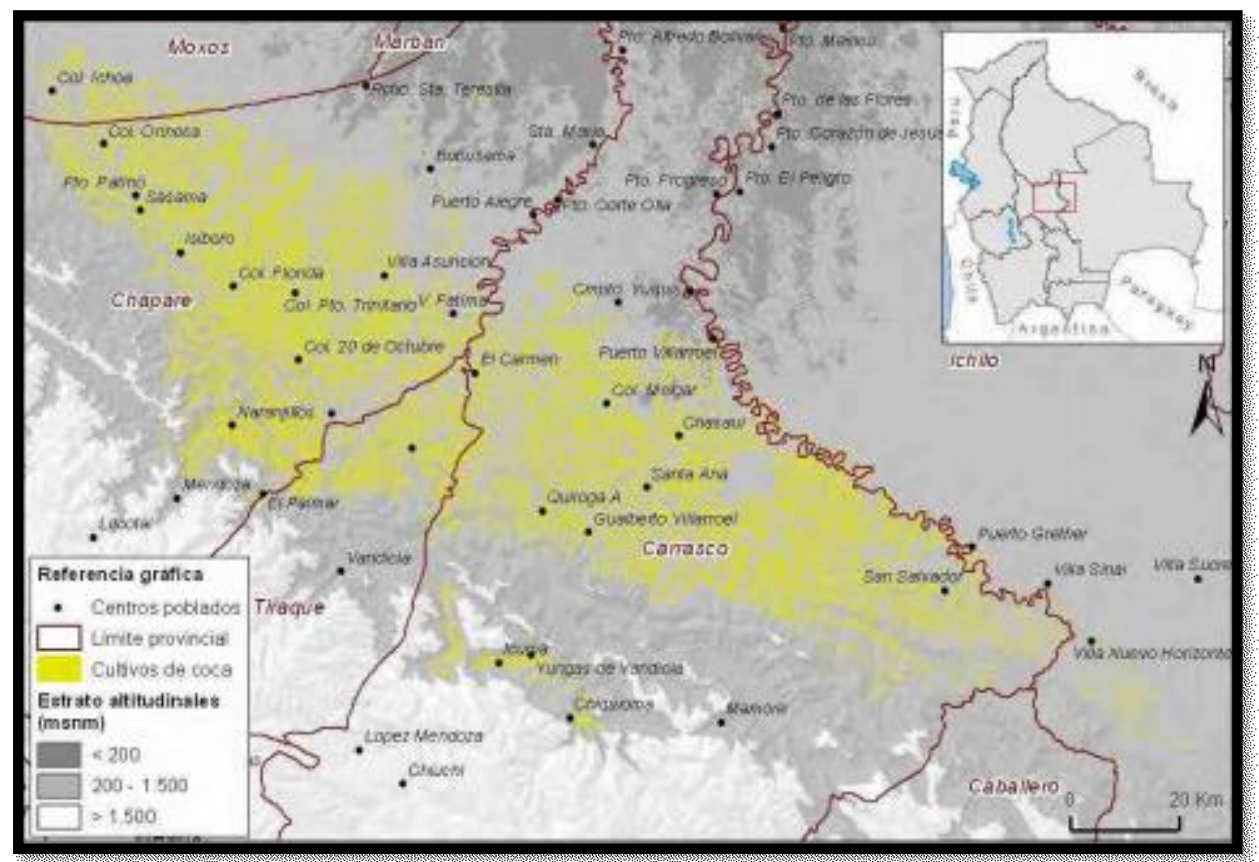

\section{Características del cultivo de coca en la región del Trópico de Cochabamba}

En la región del Trópico de Cochabamba la planta de coca se desarrolla favorecida por las características tropicales y sub tropicales de la zona. Generalmente las parcelas son de forma regular y debido al potencial productivo de la región puede encontrarse cultivos de coca rodeados por cultivos de desarrollo integral.

\section{RESULTADOS DEL MONITOREO DE CULTIVOS DE COCA EN BOLIVIA 2015}

En 2015 la superficie cuantificada de cultivos de coca en las regiones monitoreadas de Bolivia alcanzó 20.200 ha, que representa una reducción del 1\% en relación a la gestión 2014 que fue de 20.400 ha. Este cambio con relación al año anterior sugiere una tendencia a la estabilización de los cultivos.

Los datos de los últimos cinco años muestran una reducción neta de los cultivos de coca hasta llegar a 20.200 ha en 2015, y una tendencia a estabilizar la superficie de cultivos de coca pese a que las tareas de racionalización/erradicación continuaron realizándose con la misma intensidad que en años anteriores según datos reportados por el Gobierno del Estado Plurinacional de Bolivia. La superficie cultivada de coca en la región de los Yungas de La Paz disminuyó en 200 ha, equivalente a 1\% del total registrado en 2014. En el Trópico de Cochabamba, la disminución 
fue de 100 ha, lo que representa el 2\%, y en las provincias del Norte de La Paz se incrementaron 20 ha, equivalente a $15 \%$

\begin{tabular}{|c|c|c|c|c|c|c|c|c|c|c|c|c|}
\hline Región & 2005 & 2006 & 2007 & 2008 & 2009 & 2010 & 2011 & 2012 & 2013 & 2014 & 2015 & $\begin{array}{c}\text { Cambio } \\
2014-2015\end{array}$ \\
\hline $\begin{array}{l}\text { Yungas de } \\
\text { La Paz }\end{array}$ & 18.100 & 18.900 & 19.800 & 20.700 & 20.900 & 20.500 & 18.200 & 16.900 & 15.700 & 14.200 & 14.000 & $-1 \%$ \\
\hline $\begin{array}{l}\text { Trópico de } \\
\text { Cochabamba }\end{array}$ & 7.000 & 8.300 & 8.800 & 9.500 & 9.700 & 10.100 & 8.600 & 8.100 & 7.100 & 6.100 & 6.000 & $-2 \%$ \\
\hline $\begin{array}{l}\text { Provincias del } \\
\text { Norte de } \\
\text { La Paz }\end{array}$ & 300 & 300 & 300 & 300 & 300 & 400 & 370 & 320 & 230 & 130 & 150 & $15 \%$ \\
\hline $\begin{array}{l}\text { Tolal } \\
\text { redondeado }\end{array}$ & 25.400 & 27.500 & 28.900 & 30.500 & 30.900 & 31.000 & 27.200 & 25.300 & 23.000 & 20.400 & 20.200 & $-1 \%$ \\
\hline
\end{tabular}

Seguidamente en una figura reflejaremos la serie histórica de la superficie cultivada con coca desde el año 2003 hasta el 2015, mostrando una tendencia creciente de 23.600 ha en 2003 hasta alcanzar una superficie de 31.000 ha en 2010. A partir del año 2011, se observa una tendencia decreciente hasta llegar a 20.400 ha en 2014, estabilizándose a 20.200 ha en 2015. Este dato representa la superficie más baja cuantificada por la UNODC desde 2003.

Serie histórica de la superficie de cultivos de coca en Bolivia, 2003 - 2015 (ha)

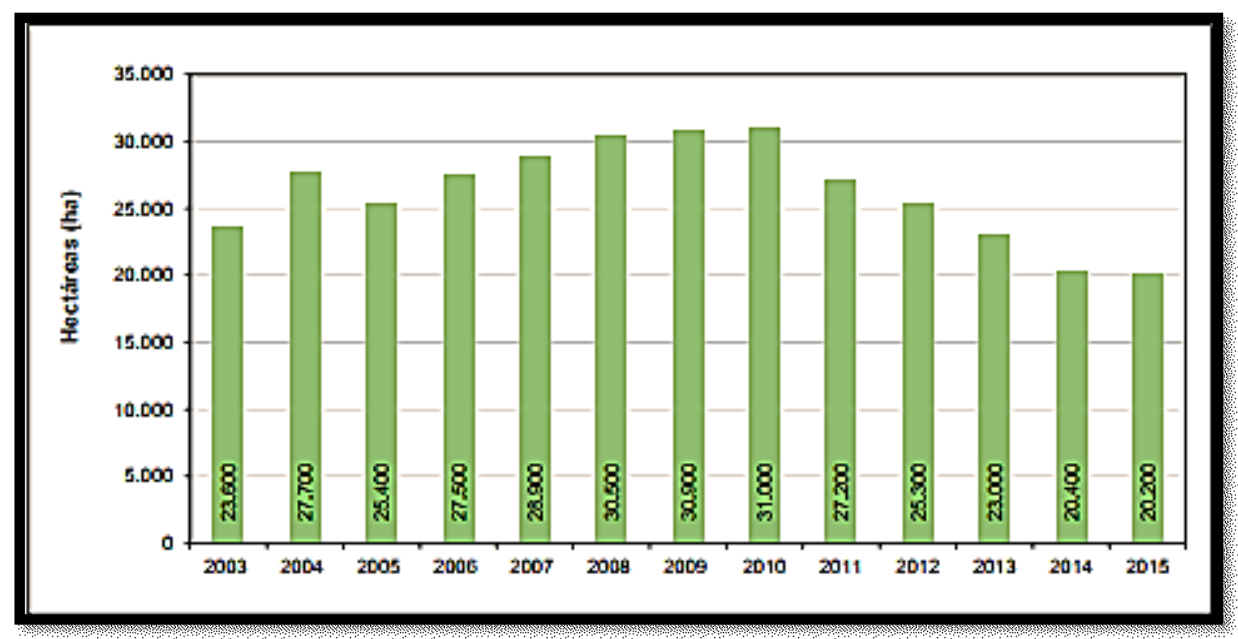

En otro tráfico mostraremos la tasa anual de variación en la superficie de cultivos de coca en Bolivia para el periodo comprendido entre 2005 y 2015. En los últimos cinco años se observa una reducción en la superficie de cultivo de $12 \%, 7 \%, 9 \%, 11 \%$ y $1 \%$ respectivamente. En el periodo 2010 - 2015, la superficie de cultivos de coca en Bolivia se ha reducido en un 35\%. 

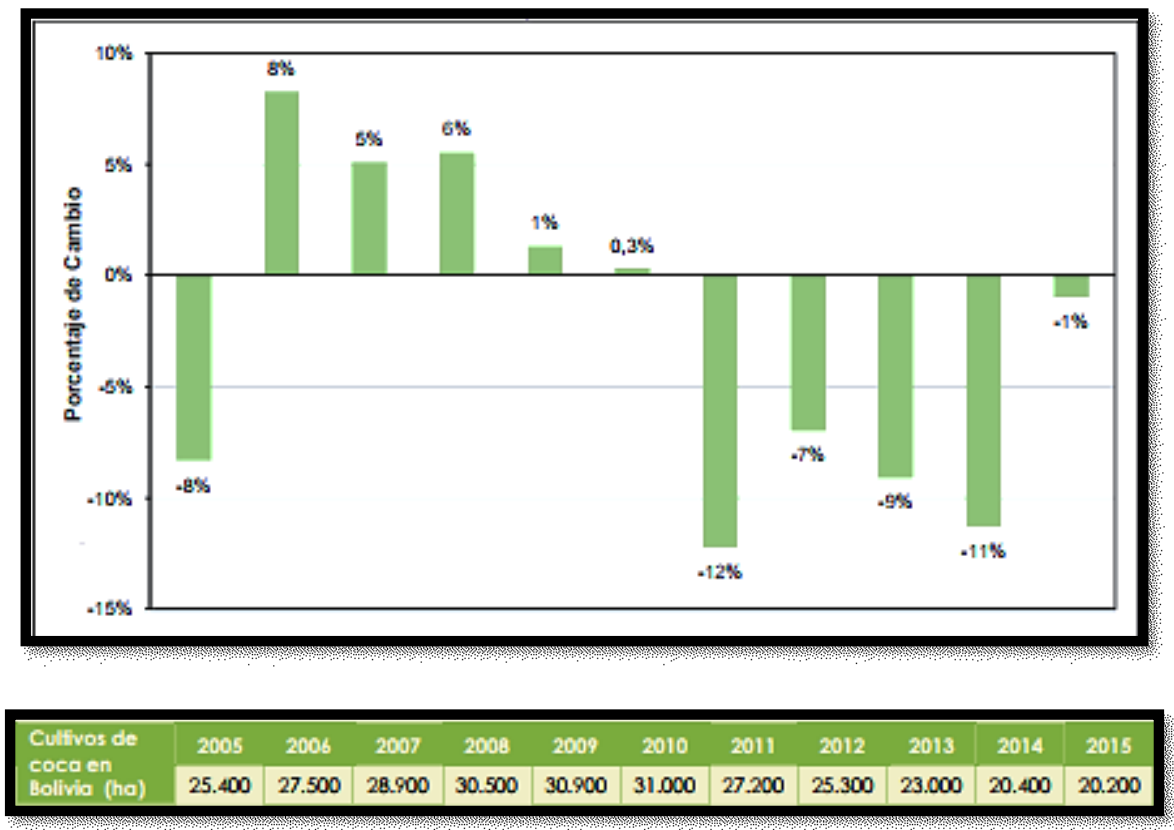

Mostramos la superficie cultivada con coca en las tres regiones monitoreadas en Bolivia. Se observa que a partir de 2011 existe una reducción en la superficie cultivada con coca en las regiones del Trópico de Cochabamba y provincias del Norte de La Paz, mientras que en los Yungas de La Paz esta tendencia se inicia a partir de 2010

Superficie de cultivos de coca por regiones, $2005-2015$

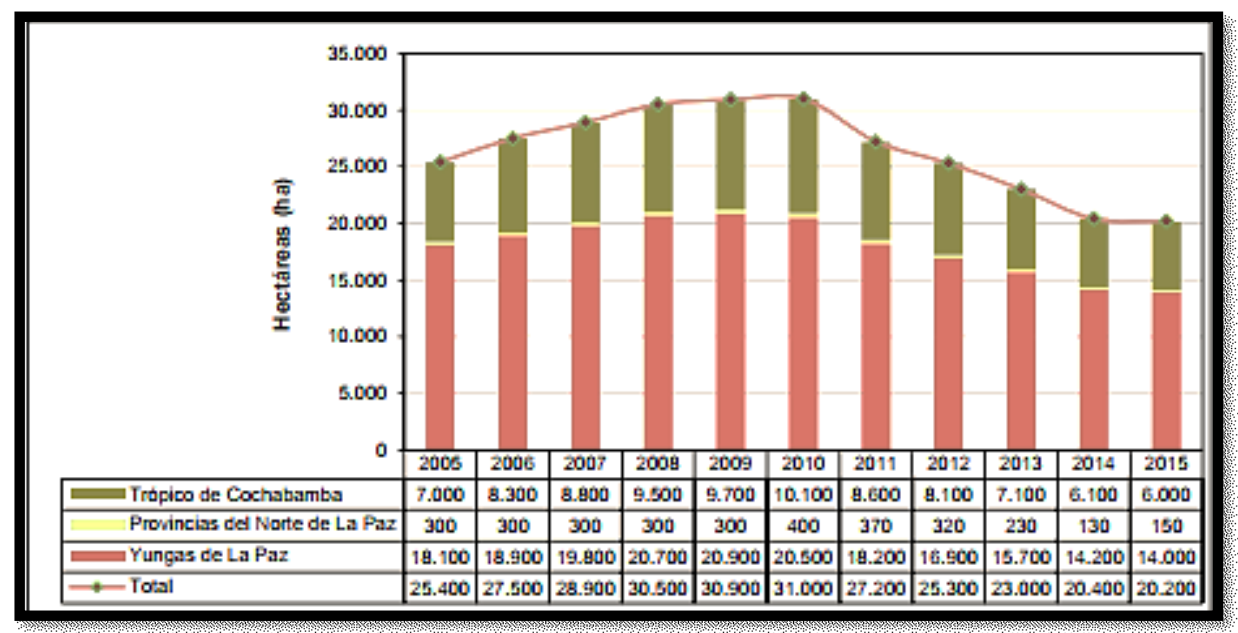

Esta reducción15 podría explicarse por la continua tarea de racionalización/erradicación de cultivos de coca, impulsada por el Gobierno del Estado Plurinacional de Bolivia a través del Comando Estratégico Operacional "Tte. Gironda” (CEO) conformado por las Fuerzas Armadas, Policía Boliviana y DIGPROCOCA con sus Unidades de Desarrollo Económico Social de los Yungas de La Paz y el Trópico de Cochabamba (UDESY y UDESTRO), bajo la dirección estratégica del Viceministerio de Defensa Social y Sustancias Controladas (VDSSC) y por las políticas de control social en coordinación con las organizaciones sociales productoras de coca. En los Yungas de La Paz la reducción, se debe también en parte al abandono de cultivos de coca 
antiguos. En las provincias del Norte de La Paz se evidenció desde la gestión 2013 una alta incidencia de las tareas de racionalización/erradicación de cultivos de coca. Sin embargo en 2015 la superficie cuantificada registró un incremento. El siguiente mapa muestra la ubicación espacial y la densidad de cultivos de coca en Bolivia. Como se puede observar, la mayor extensión de este cultivo se ubica en la región del Trópico de Cochabamba. Sin embargo las zonas con mayor densidad se concentran en la región de los Yungas de La Paz, donde gran parte del cultivo es tradicional.

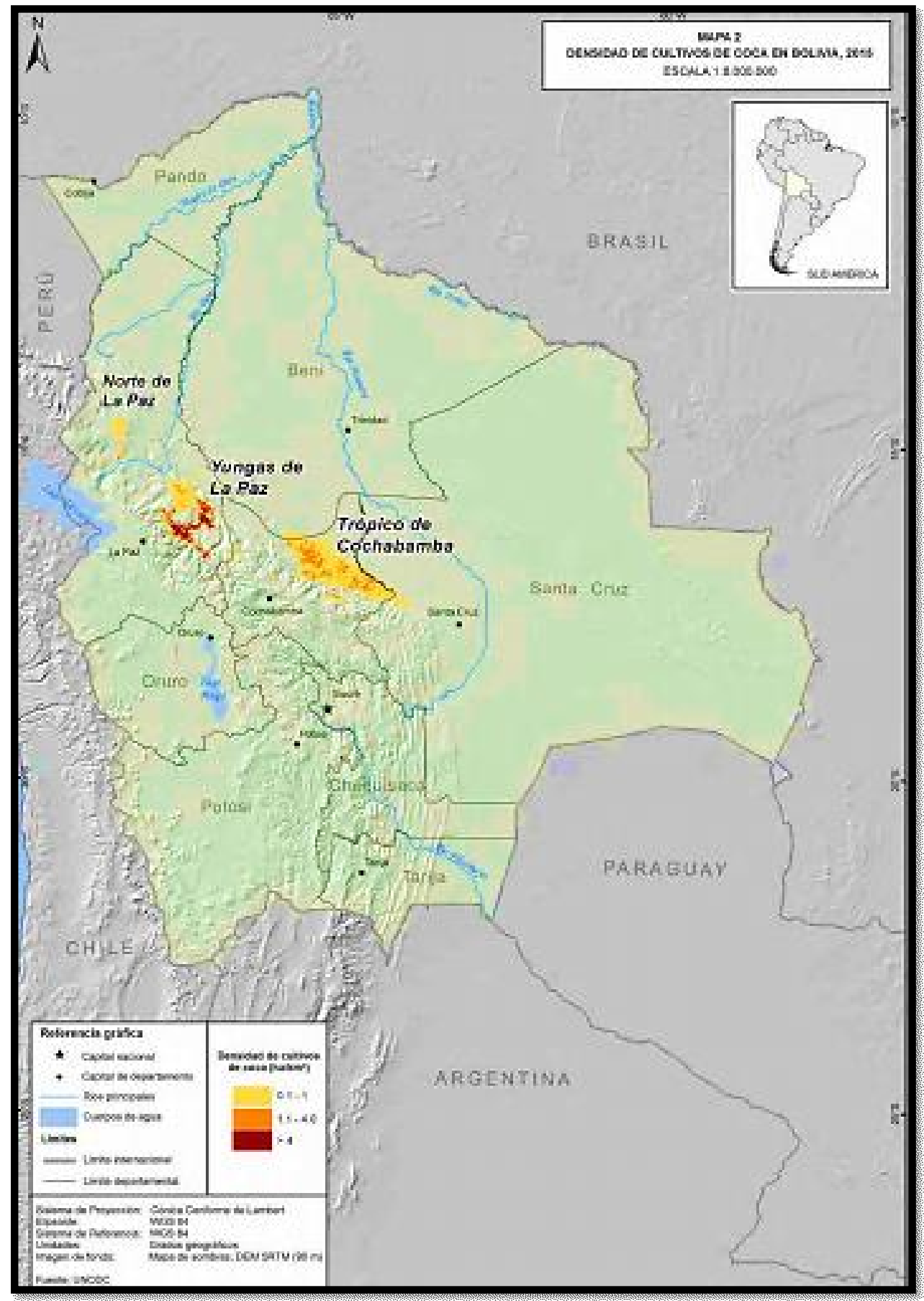




\section{Región de los Yungas de La Paz}

En 2015, la superficie con cultivos de coca en los Yungas de La Paz disminuyó 200 ha, de 14.200 ha en 2014 a 14.000 ha en 2015, lo que equivale a una reducción de 1\%. La provincia donde se registró la mayor reducción de la superficie cultivada con coca fue Nor Yungas, que disminuyó un 12\%. En cambio en la Provincia Sud Yungas la superficie de cultivos de coca se incrementó en $3 \%$

Cultivos de coca por provincias en la región de los Yungas de La Paz, 2005 - 2015 (ha)

\begin{tabular}{|c|c|c|c|c|c|c|c|c|c|c|c|c|}
\hline Provineio & 2005 & 2006 & 2007 & 2008 & 2009 & 2010 & 2011 & 2012 & 2013 & 2014 & 2015 & $\begin{array}{c}\text { Cambio } \\
2014-2015\end{array}$ \\
\hline Sud Yungas & 9.395 & 9.753 & 10.588 & 11.291 & 13.731 & 13.068 & 11.205 & 10.619 & 9.793 & 9.009 & 9.309 & $3 \%$ \\
\hline Nor Yungas & 6.257 & 6.432 & 6.532 & 6.654 & 4.936 & 4.912 & 4.899 & 4.234 & 4.112 & 3.467 & 3.057 & $-12 \%$ \\
\hline Inquisivi & 807 & 809 & 813 & 897 & 909 & 978 & 790 & 905 & 819 & $E O B$ & 822 & $2 \%$ \\
\hline Caranavi & 1.381 & 1.714 & 1.653 & 1.530 & 1.211 & 1.349 & 1.205 & 999 & ass & 797 & 720 & $-10 \%$ \\
\hline Murillo & 223 & 225 & 229 & 247 & 74 & 102 & 81 & 78 & 78 & 78 & 65 & $-16 \%$ \\
\hline Larecaja & & & & & & 92 & 52 & 56 & 57 & 57 & 38 & $-33 \%$ \\
\hline Tolal & 18.063 & 18.933 & 19.815 & 20.719 & 20.861 & 20.501 & 18.232 & 16.890 & 15.704 & 14.221 & 14.017 & $.1 \%$ \\
\hline $\begin{array}{l}\text { Tolal } \\
\text { redondeado }\end{array}$ & 18.100 & 18.900 & 19.800 & 20.700 & 20.900 & 20.500 & 18.200 & 16.900 & 15.700 & 14.200 & 14.000 & $.1 \%$ \\
\hline
\end{tabular}

De acuerdo al análisis visual de las imágenes satelitales adquiridas por la UNODC y los puntos de racionalización/erradicación proporcionados por el Gobierno de Bolivia, las poblaciones donde se registró mayor esfuerzo en las tareas de racionalización/erradicación de cultivos de coca son: Alto los Andes, Flor de Mayo y San Luis en el Municipio de Caranavi; las poblaciones de Monteagudo y Tablamarca en el Municipio de Teoponte; y la población de Santo Domingo y Entre Ríos Km 52 en el Municipio de Alto Beni.

La serie de datos del grafico que continua muestra dos periodos que marcan la tendencia de la superficie de cultivos de coca de la región de los Yungas de La Paz. Se observa que durante el periodo 2005 - 2009, la superficie de cultivos de coca se incrementó sostenidamente, de 18.100 a 20.900 ha. A partir del 2010 la tendencia disminuye de manera continua, hasta alcanzar 14.000 ha en 2015.

En la Provincia Sud Yungas se observa, que en el periodo 2005 - 2009 se registró una tendencia creciente en la superficie cultivada con coca de 9.395 a 13.731 ha. En el periodo 2009 - 2014 se registró un decremento de 13.731 a 9.009 ha y en 2015 la tendencia cambia registrándose un incrementó de 300 ha, debido a la habilitación de nuevos cultivos de coca 


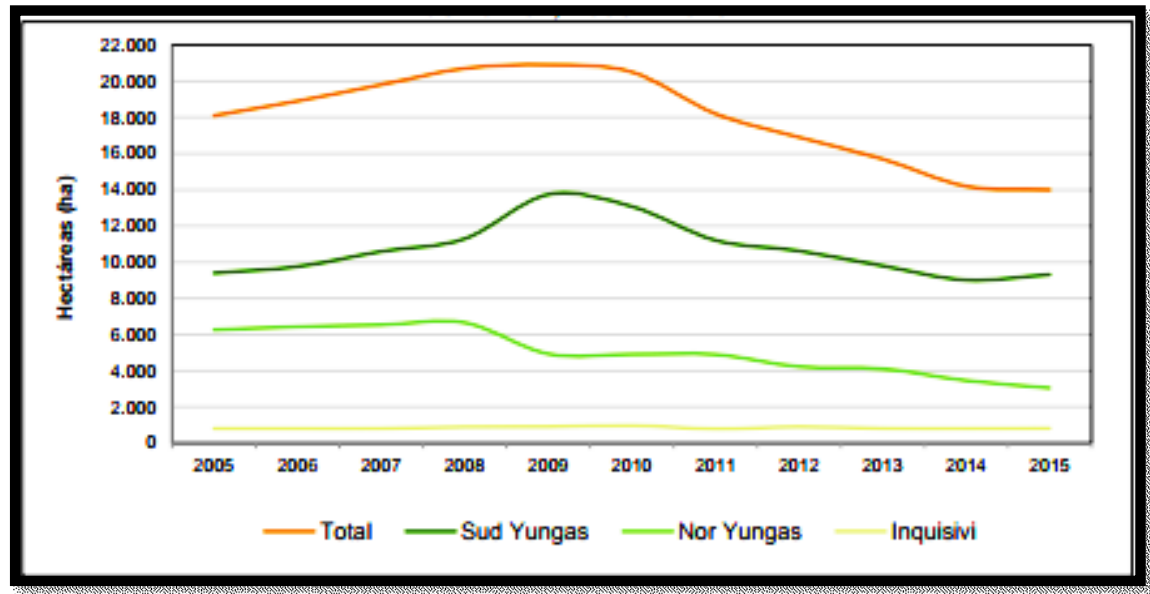

Las provincias Sud y Nor Yungas son las principales productoras de cultivos de coca en la región de los Yungas de La Paz. Ambas representan el 88\% de la superficie cultivada con coca, seguido por las provincias Inquisivi y Caranavi que representan el 11\%.

Distribución del cultivo de coca por provincias en los Yungas de La Paz (14.000 ha), 2015

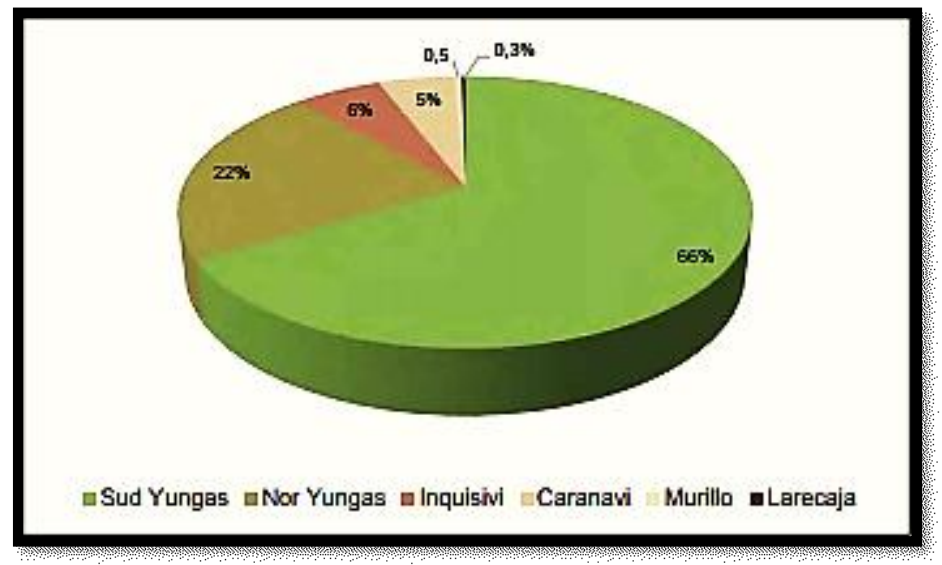

\section{Región de las provincias del Norte de La Paz}

En 2015 la superficie cultivada con coca en las provincias del Norte de La Paz se ha incrementado en un 15\% en comparación con 2014, de 130 a 150 ha. El incremento de cultivos de coca en esta región se distribuye en las tres provincias monitoreadas. El mayor incremento se produjo en la Provincia Franz Tamayo, que en el último año incrementó de 93 a 106 ha (13\%)

Cultivos de coca por provincias en la región del Norte de La Paz, 2009 - 2015 (ha)

\begin{tabular}{|l|r|r|r|r|r|r|r|r|}
\hline \multicolumn{1}{|c|}{ Provincia } & 2009 & 2010 & 2011 & 2012 & 2013 & 2014 & 2015 & $\begin{array}{c}\text { Cambio } \\
2014-2015\end{array}$ \\
\hline $\begin{array}{l}\text { Franz Tamayo } \\
\text { (Apolo) }\end{array}$ & 220 & 327 & 250 & 193 & 121 & 93 & 106 & $13 \%$ \\
\hline $\begin{array}{l}\text { Muñecas } \\
\text { Baulista Saavedra }\end{array}$ & 55 & 29 & 25 & 47 & 43 & 19 & 21 & $9 \%$ \\
\hline Total & 310 & 398 & 71 & 81 & 64 & 15 & 18 & $23 \%$ \\
\hline Total redondeado & 300 & 400 & 370 & 320 & 229 & 127 & 145 & $14 \%$ \\
\hline
\end{tabular}


El cultivo de coca en las provincias del Norte de La Paz representa aproximadamente el 1\% del total de la superficie cultivada con coca de las tres regiones de monitoreo en el país. El 73\% de la superficie cultivada de coca en esta región se encuentra en la Provincia Franz Tamayo

Distribución del cultivo de coca por provincias en el Norte de La Paz (150 ha), 2015

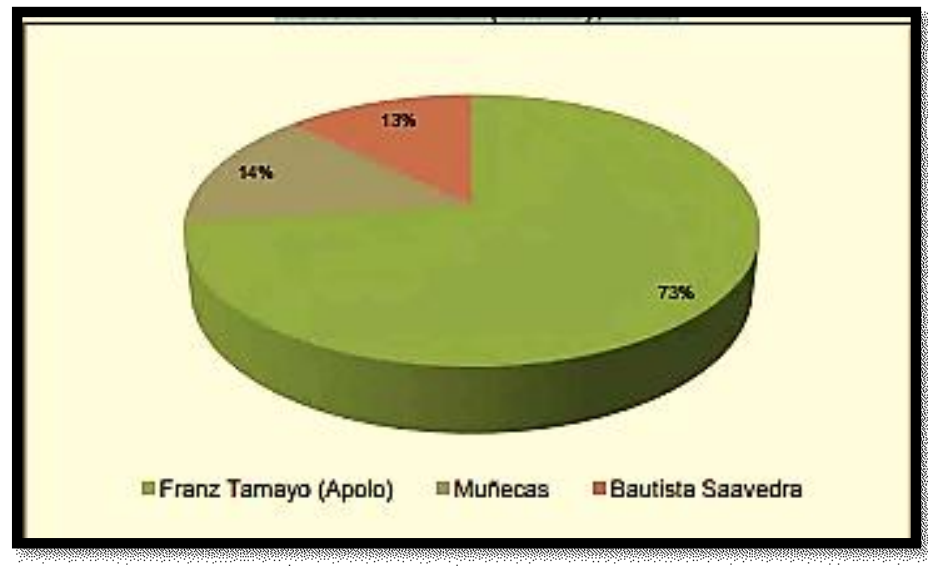

\section{Región del Trópico de Cochabamba}

Los cultivos de coca en la región del Trópico de Cochabamba se han reducido de 6.100 ha en 2014 a 6.000 ha en 2015, mostrando una reducción del 2\% equivalente a 100 ha. Esta reducción de cultivos de coca se evidencia principalmente en las provincias de Chapare y Carrasco donde los cultivos de coca disminuyeron en 92 ha y 72 ha respectivamente. En la Provincia Tiraque hubo un incremento de 12 ha y en la Provincia Ichilo del Departamento de Santa Cruz los cultivos de coca se incrementaron en $43 \%$, equivalente a 27 ha.

Cultivos de coca por provincias en la región del Trópico de Cochabamba, 2005 - 2015 (ha)

\begin{tabular}{|c|c|c|c|c|c|c|c|c|c|c|c|c|}
\hline Provinala & 200 & 200: & $200 r$ & 200 & 200 & 2010 & 2011 & 2012 & 2013 & 2014 & 2015 & $\begin{array}{l}\text { Cambla } \\
20142015\end{array}$ \\
\hline Chapare & 4.6h4 & 4.EST & 4.506 & 4767 & $5 \pi 0$ & 485 & 3.482 & 3.628 & 3071 & $2 B S 4$ & 2.772 & 37 \\
\hline Corrasco & 2.312 & 2.741 & 3.442 & $3 \mathrm{ebr}$ & $3 . \mathrm{THS}$ & 4.338 & 4006 & 3.714 & 3.323 & 2.75 & 2.685 & $.3 x$ \\
\hline Tiraque & $\cos$ & 691 & 77 & 954 & set & 70 & 813 & $m$ & 634 & 445 & 468 & $3 x$ \\
\hline $\begin{array}{l}\text { Ichilo (Dpia. } \\
\text { santa Cruz) }\end{array}$ & & & & & & $y$ & 4 & 47 & 48 & 63 & 90 & 407 \\
\hline Total & 7.011 & B.234 & B.eos & 7503 & 9.701 & 10.13 & 8.551 & ㅂ. 111 & 7076 & 6.130 & 5.005 & 25 \\
\hline $\begin{array}{l}\text { Total } \\
\text { redondeado }\end{array}$ & 7.000 & 0.300 & a.800 & 9.500 & 9.700 & 10 & 8.00 & 8.100 & 7.100 & 4100 & 6000 & -27 \\
\hline
\end{tabular}

El siguiente cuadro muestra que los cultivos de coca en la región del Trópico de Cochabamba en el periodo 2005 - 2010 presentan una tendencia creciente, aumentando la superficie cultivada con coca de 7.000 a 10.100 ha. A partir del año 2011, la superficie cultivada con coca registra una reducción continua de 8.600 a 6.000 ha en 2015 .

Tendencia del cultivo de coca en las provincias productoras del Trópico de Cochabamba, 2005 - 2015 


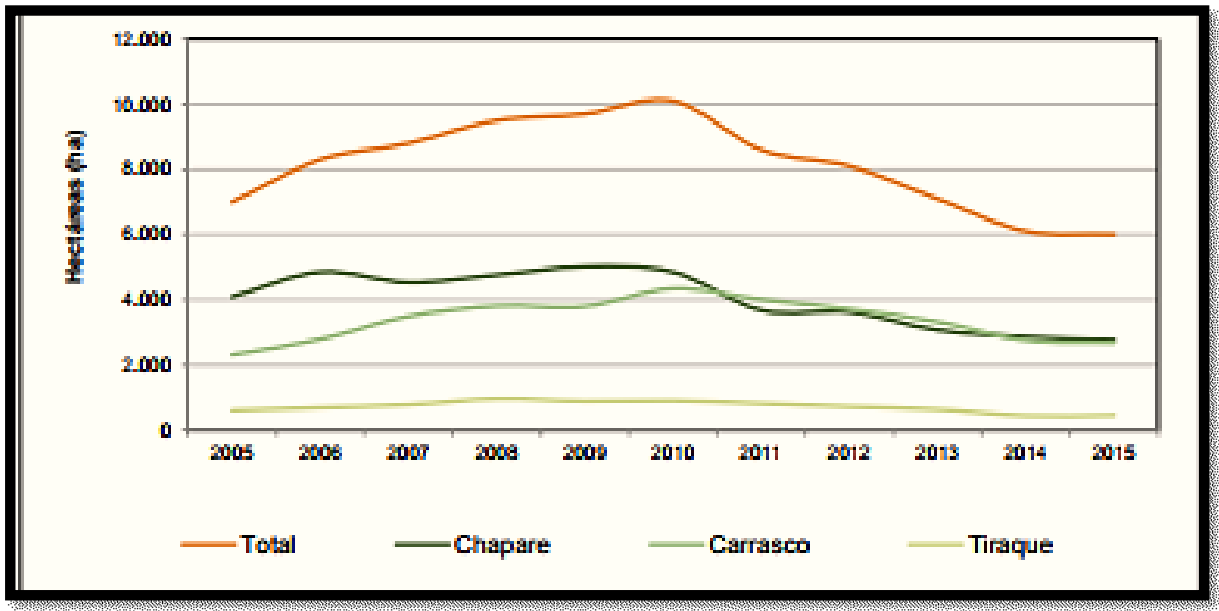

El cultivo de coca en la Provincia Chapare se incrementó de 4.094 ha a 5.020 ha en el periodo 2005 - 2009. A partir de 2010 la superficie cultivada con coca disminuye un $43 \%$ hasta alcanzar 2.772 ha en 2015. En la Provincia Carrasco la superficie de cultivos de coca durante el periodo 2005 - 2010 se incrementó de 2.312 ha a 4.338 ha. Desde 2011, la superficie con cultivos de coca disminuyó en 33\% hasta alcanzar 2.685 ha en 2015.

La serie de datos en la Provincia Tiraque muestra que durante el periodo 2005 - 2008 la superficie cultivada con coca se incrementó de 605 ha a 959 ha. A partir del 2009 se presenta una tendencia a la reducción en la superficie de cultivos de coca, sin embargo en 2015 se presentó un incremento de 3\% respecto a 2014. En la Provincia Ichilo del Departamento de Santa Cruz, el monitoreo de cultivos de coca se inició en 2010. Desde entonces la superficie cultivada con coca se incrementó de 39 ha a 90 ha en 2015. En esta provincia a diferencia del resto, registra un crecimiento de 63 ha en 2014 a 90 ha en 2015.

El Siguiente grafico muestra que las provincias de Chapare y Carrasco son las principales productoras de coca en la región del Trópico de Cochabamba, debido a que ambas concentran el 91\% de la superficie cultivada con coca en la región. Las provincias de Tiraque e Ichilo representan el $8 \%$ y $1 \%$ respectivamente

Distribución del cultivo de coca por provincias en el Trópico de Cochabamba (6.000ha), 2015 


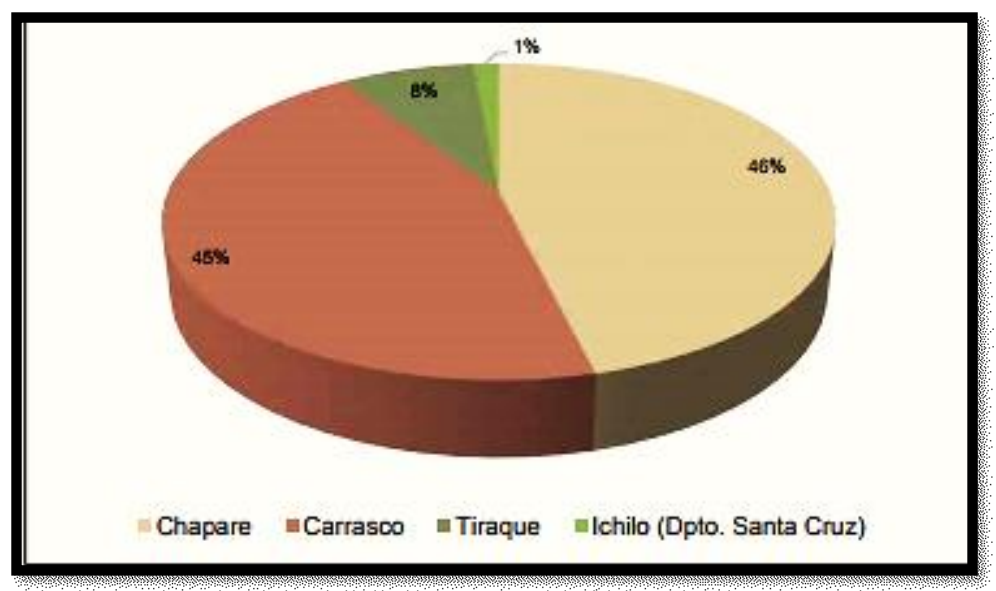

\section{PRODUCCIÓN DE LA HOJA DE COCA}

El Gobierno de Bolivia y la UNODC realizaron un trabajo de revisión conjunta de los datos de rendimiento del "Estudio de Productividad Media de la Hoja de Coca en Bolivia" (EPMHCB). La conclusión más importante de esta revisión es que los factores de rendimiento publicados pueden haber variado desde su estimación en 2010. En este sentido, para los cálculos de rendimiento y producción, se emplearon los resultados del EPMHCB, elaborado por el Estado Plurinacional de Bolivia en 2010. Asimismo, se utilizaron los resultados del estudio de rendimiento realizado en los Yungas de La Paz por la UNODC en 2005 y la información de la “Operación Breakthrough” realizada en el Trópico de Cochabamba en 1993.

Con el apoyo del Programa de Monitoreo de Cultivos Ilícitos (ICMP) se ha establecido una metodología para la estimación final de la producción potencial de la hoja de coca. Las 12.000 ha de cultivos de coca permitidas por la Ley 1008 han sido distribuidas proporcionalmente de acuerdo al porcentaje de cultivos de coca existentes en cada región de monitoreo. Esto significa que de las 20.200 ha, 12.000 fueron distribuidas como sigue: 69\% para los Yungas de La Paz, $30 \%$ en el Trópico de Cochabamba y 1\% para las provincias del Norte de La Paz. A estos cultivos se aplicó los factores de rendimiento correspondientes del EPMHCB. Para las restantes 8.200 ha, se utilizan los factores de rendimiento de la UNODC para los Yungas y provincias del Norte de La Paz y de la “Operación Breakthrough” para el Trópico de Cochabamba.

\section{Comercialización y precios de la hoja de coca en Bolivia}

En la estructura del Viceministerio de Coca y Desarrollo Integral (VCDI) se encuentra la Dirección General de la Hoja de Coca e Industrialización (DIGCOIN) cuyas funciones se enmarcan en las disposiciones establecidas por el Reglamento de Circulación y Comercialización Tesis de Maestría 
de la Hoja de Coca en estado natural. DIGCOIN es la instancia que autoriza y supervisa la circulación de los volúmenes y registra los precios de la hoja de coca que se comercializa en los mercados legales de Villa Fátima en la ciudad de La Paz y Sacaba en la ciudad de Cochabamba. En 2015, DIGCOIN registró en los mercados autorizados una comercialización total de 21.201 toneladas métricas de hoja de coca, cifra que representa un $7 \%$ adicional a la cantidad registrada en 2014, que fue de 19.798 toneladas métricas. El volumen de hoja de coca comercializada a nivel nacional registrado es el más alto de la serie histórica y mantuvo una tendencia relativamente estable en el periodo $2008-2015$.

Producción y comercialización de hoja de coca a nivel nacional, 2005 - 2015

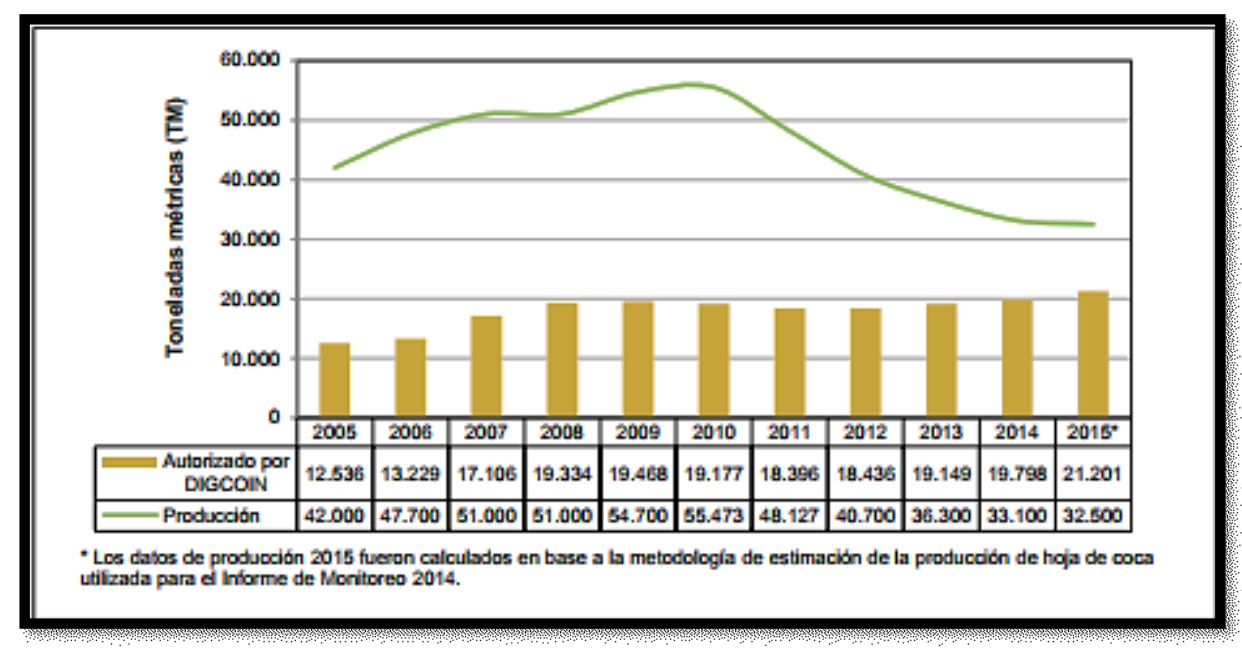

Según información reportada por DIGCOIN, la cantidad comercializada de hoja de coca en el mercado de Villa Fátima aumentó de 18.459 toneladas métricas en 2014 a 19.615 toneladas métricas en 2015, lo que representó un incremento del 6\%, el mismo fenómeno se observó en el mercado de Sacaba, donde la cantidad comercializada de hoja de coca aumentó de 1.338 toneladas métricas en 2014 a 1.586 toneladas métricas en el 2015, un incremento del 19\%.

La Tabla 10 muestra que de un total de 21.201 toneladas métricas de hoja de coca, el 93\% fue comercializado en el mercado de Villa Fátima del Departamento de La Paz y el restante 7\% se comercializó en el mercado de Sacaba del Departamento de Cochabamba.

La producción estimada de hoja de coca para los Yungas y Norte de La Paz (18.500 TM) es inferior a los datos de comercialización reportados por DIGCOIN en el mercado de Villa Fátima (19.615 TM). Una de las causas probables son los factores de rendimiento que se encuentran desactualizados, también existen evidencias que el rendimiento del cultivo de coca en los 
Yungas de La Paz se ha incrementado debido al uso de nuevas técnicas de manejo del cultivo de coca.

El mayor movimiento comercial de hoja de coca en los mercados autorizados del país fue generado por los comerciantes detallistas que representan el $62 \%$, porcentaje menor en relación al año pasado (69\%), seguido por el de los productores detallistas (37\%), el cual representó un porcentaje mayor al año anterior (31\%) y las otras formas de comercialización de la hoja de coca, trueque e industrialización se han mantenido en 0,6 y $0,1 \%$, respectivamente, mismo porcentaje que el año anterior

Formas y volúmenes de comercialización de hoja de coca autorizada, 2015 (TM

\begin{tabular}{|c|c|c|c|c|}
\hline \multirow{2}{*}{$\begin{array}{l}\text { Formas de } \\
\text { Comercialización }\end{array}$} & \multicolumn{2}{|c|}{ DIGCOIN Mercados autorizados } & \multirow[b]{2}{*}{ Total } & \multirow[b]{2}{*}{ Porcentaje } \\
\hline & $\begin{array}{l}\text { Mercado de Villa Fálima } \\
\text { (La Paz) }\end{array}$ & $\begin{array}{l}\text { Mercado de Sacaba } \\
\text { (Cochabamba) }\end{array}$ & & \\
\hline Comerciantes Defallistas & 12.329 & 778 & 13.106 & $62 \%$ \\
\hline $\begin{array}{l}\text { Productores Detallistas } \\
\text { (Venta Directa) }\end{array}$ & 7.216 & 722 & 7.937 & $37 \%$ \\
\hline Trueques & 44 & 86 & 130 & $0,6 \%$ \\
\hline $\begin{array}{l}\text { Provisión para } \\
\text { industrialización }\end{array}$ & 27 & 0,5 & 27 & $0,1 \%$ \\
\hline Totales & 19.615 & 1.586 & 21.201 & $100 \%$ \\
\hline Porcentaje & $93 \%$ & $7 \%$ & $100 \%$ & \\
\hline
\end{tabular}

El comerciante detallista es aquella persona registrada y acreditada por DIGCOIN que cuenta con un puesto de venta autorizado por el ente regulador dentro de su jurisdicción para la comercialización de hoja de coca en su estado natural.

El productor detallista es toda persona debidamente registrada y acreditada por DIGCOIN y que comercializa directamente su producción en estado natural al por menor directamente al consumidor. El trueque es una modalidad de comercialización tradicional y ancestral, donde la hoja de coca es intercambiada en su estado natural por otro bien o producto. Esta forma de comercialización se realiza en ferias o directamente con los productores campesinos, artesanales y demás consumidores legales.

La provisión de hoja de coca para la industrialización es una forma de uso y destino como materia prima para las industrias farmacéuticas, para estudios de investigación $\mathrm{y} / \mathrm{u}$ otras acreditadas conforme a la normativa vigente. En 2015, el precio nominal promedio de la hoja de coca comercializada en los mercados de Villa Fátima y Sacaba fue igual a 9,6 USD/Kg y 6,9 $\mathrm{USD} / \mathrm{Kg}$ respectivamente 29 , lo que representó un incremento de $15 \%$ en el mercado de Villa Tesis de Maestría 
Fátima y un decremento de $22 \%$ en el mercado de Sacaba con respecto a 2014 como se muestra en las siguientes tablas.

Precios nominales mensuales de hoja de coca comercializada por comerciantes detallistas en mercados autorizados, 2015

\begin{tabular}{|c|c|c|c|c|c|c|c|c|}
\hline \multirow{2}{*}{ Mes } & \multicolumn{3}{|c|}{$\begin{array}{l}\text { Mercado de Villa Fálima } \\
\text { (La Paz) }\end{array}$} & \multicolumn{3}{|c|}{$\begin{array}{l}\text { Mercado de Sacaba } \\
\text { (Cochabamba) }\end{array}$} & \multicolumn{2}{|c|}{$\begin{array}{l}\text { Promedio } \\
\text { ponderado* }\end{array}$} \\
\hline & Bs./Kg & USD/Kg & $\begin{array}{l}\text { Cantidad } \\
\text { comercializada } \\
\text { (TM) }\end{array}$ & Bs./Kg & USD/Kg & $\begin{array}{l}\text { Canlidad } \\
\text { comerciolizada } \\
\text { (TM) }\end{array}$ & Bs./Kg & UsD/Kg \\
\hline Enero & 62 & 9,0 & 1.623 & 44 & 6,3 & 129 & 61 & 8,8 \\
\hline Febrero & 62 & 9,0 & 1.620 & 53 & 7,6 & 69 & 62 & 8,9 \\
\hline Marzo & 63 & 9,0 & 1.663 & 51 & 7,3 & 106 & 62 & 8,9 \\
\hline Abril & 71 & 10,1 & 1.700 & 42 & 6,0 & 161 & 68 & 9,8 \\
\hline Mayo & 77 & 11,0 & 1.628 & 42 & 6,0 & 166 & 74 & 10,6 \\
\hline Junio & 66 & 9,5 & 1.699 & 48 & 6,9 & 171 & 64 & 9,3 \\
\hline Julio & 63 & 9,1 & 1.626 & 53 & 7,6 & 106 & 62 & 9,0 \\
\hline Agosto & 81 & 11,6 & 1.565 & 56 & 8,0 & 84 & 79 & 11,4 \\
\hline Sepliembre & 67 & 9,6 & 1.506 & 51 & 7,3 & 135 & 66 & 9,5 \\
\hline Octubre & 64 & 9,1 & 1.664 & 45 & 6,4 & 140 & 62 & 8,9 \\
\hline Noviembre & 67 & 9,6 & 1.634 & 48 & 6,9 & 164 & 65 & 9,3 \\
\hline Diciembre & 58 & 8,3 & 1.686 & 42 & 6,0 & 157 & 56 & 8,1 \\
\hline $\begin{array}{l}\text { Promedio } \\
\text { anual }\end{array}$ & 67 & 9,6 & 1.635 & 48 & 6,9 & 132 & 65 & 9,4 \\
\hline Total & & & 19.615 & & & 1.586 & - & - \\
\hline
\end{tabular}

* Promedio ponderado en base a la cantidad comercializada en ambos mercados autorizados.

Tipo de cambio según BCB: 6,96 Bs./USD Fecha: 20/04/2016.

Comparando los precios por kilogramo de hoja de coca a lo largo del año para ambos mercados, se observó que en el mes de agosto se reportaron los valores más altos. En ese mes el kilogramo de hoja de coca llegó a costar 11,6 USD (81 Bs.) en el mercado de Villa Fátima y 8 USD (56 Bs.) en el mercado de Sacaba. El precio promedio nacional ponderado de un kilogramo de hoja de coca considerando ambos mercados fue de 9,4 USD (65 Bs.), siendo un 13\% mayor que en 2014

Precios promedio de hoja de coca en mercados autorizados, 2014 - 2015

\begin{tabular}{|c|c|c|c|c|c|}
\hline \multirow{2}{*}{ Mercado } & \multicolumn{2}{|c|}{2014} & \multicolumn{2}{|c|}{2015} & \multirow{2}{*}{$\begin{array}{c}\text { Cambio } \\
2014-2015\end{array}$} \\
\hline & Bs./Kg & USD $/ \mathrm{Kg}$ & Bs./ $/ \mathrm{Kg}$ & USD $/ \mathrm{Kg}$ & \\
\hline $\begin{array}{l}\text { Precio promedio en el mercado de Villa } \\
\text { F́́tima (La Paz) }\end{array}$ & 57 & 8,3 & 67 & 9,6 & $15 \%$ \\
\hline $\begin{array}{l}\text { Precio promedio en el mercado de Sacaba } \\
\text { (Cochabamba) }\end{array}$ & 61 & 8,8 & 48 & 6,9 & $-22 \%$ \\
\hline $\begin{array}{l}\text { Precio promedio nacional ponderado de } \\
\text { acuerdo a la cantidad vendida por } \\
\text { mercado) }\end{array}$ & 58 & 8,3 & 65 & 9,4 & $13 \%$ \\
\hline
\end{tabular}


En el periodo 2005 - 2015, las estadísticas registradas por DIGCOIN muestran que el volumen comercializado de hoja de coca a nivel nacional se incrementó en un $69 \%$ de 12.536 a 21.201 toneladas métricas (ver Tabla 13). En ese mismo periodo el Departamento de Santa Cruz continuó siendo el mayor comercializador de hoja de coca a nivel nacional con excepción de 2008 cuando fue superado por el Departamento de La Paz.

Comercialización de hoja de coca por departamento, 2005 - 2015 (TM)

\begin{tabular}{|c|c|c|c|c|c|c|c|c|c|c|c|c|c|}
\hline Departamento & 2005 & 2008 & 2007 & 2008 & 2009 & 2010 & 2011 & 2012 & 2013 & 2014 & 2015 & \begin{tabular}{|c|} 
Combio \\
$2014-$ \\
2015
\end{tabular} & $\begin{array}{l}\text { Combio } \\
2005- \\
2015\end{array}$ \\
\hline Santa Cruz & $4,480,7$ & $4.629,0$ & $4.773,6$ & $4.705,0$ & 7213,0 & $7.153,6$ & $6.871,5$ & $6.988,0$ & $7.325,8$ & $7.628,1$ & 7.749 .7 & $2 \%$ & $73 \%$ \\
\hline La Paz & $1.532,1$ & $1.415,1$ & $4.435,7$ & $5.44 \delta_{r} 7$ & $1.874,0$ & $1.515,9$ & 1.277 .1 & $1.141,0$ & $1.157,8$ & $1.132,9$ & $1.160,2$ & $2 \%$ & $-24 \%$ \\
\hline Cochabamba & $1.352,3$ & $1.640,8$ & $2.266,6$ & $3.505,3$ & 3298,0 & $3.016,8$ & $2.695,2$ & $2.361,0$ & $2.505,6$ & $2.462,8$ & $2.938,9$ & $19 \%$ & $117 \%$ \\
\hline Bent & 217,6 & 245,8 & 277,9 & 279,3 & $\triangle 58,0$ & 577,3 & 518,2 & 534,0 & 576,2 & 661,2 & 741,9 & $12 \%$ & $241 \%$ \\
\hline Oruro & 691,1 & 775,4 & 781,2 & 793,0 & $1.154,0$ & $1.235,9$ & $1.195,6$ & $1.364,0$ & $1.436,8$ & $1.599,2$ & $2.035,7$ & $27 \%$ & $195 \%$ \\
\hline Pando & 46,3 & 44,6 & 35,8 & 39,4 & $\Delta B, 0$ & 70,7 & 76,6 & 84,0 & 91,3 & 98,1 & 112,5 & $15 \%$ & $143 \%$ \\
\hline Tarlja & 2004,2 & $2.204,4$ & $2.230,5$ & $2.254,3$ & 2726,0 & $2.802,9$ & $2.934,9$ & $3,087,0$ & $3.186,5$ & $3.330,3$ & $3.295,1$ & $-1 \%$ & $58 \%$ \\
\hline Potosi & 1.459 .7 & $1.588,4$ & $1.623,8$ & $1.622,6$ & $1.933,0$ & $2.050,3$ & $2.075,1$ & $2.098,0$ & $2.073,5$ & $2.0 \leq 0,9$ & $2.311,2$ & $12 \%$ & $58 \%$ \\
\hline Chuquisaca & 671,8 & 685,4 & 680,5 & 688,6 & 744,0 & 753,3 & 751,5 & 779,0 & 795,6 & 824,0 & 856,3 & $4 \%$ & $27 \%$ \\
\hline Tolal & 12538 & 13.229 & 17.108 & 19.334 & $19.48 \mathrm{~B}$ & 19.177 & 18.396 & 18.438 & 19.148 & 19.798 & 21.201 & $7 \%$ & $69 \%$ \\
\hline
\end{tabular}

Según los datos de DIGCOIN, la comercialización de hoja de coca en el país se incrementó en 7\%, de 19.797 toneladas métricas en 2014 a 21.201 toneladas métricas en 2015. A nivel de departamentos, el Departamento de Tarija es el único que presentó una leve disminución del 1\% en la comercialización de hoja de coca. En los restantes departamentos la comercialización de hoja de coca experimentó un incremento, resalta en este aspecto el Departamento de Oruro con un $27 \%$.

El siguiente mapa muestra la distribución de la comercialización de hoja de coca en 2015 por departamento. Santa Cruz y Tarija son los departamentos que comercializan la mayor cantidad de hoja de coca a nivel nacional con el 37\% y 16\%, seguido de los departamentos de Cochabamba, Potosí y Oruro con el 14\%, 11\% y 10\%, respectivamente 
Maestría en Inteligencia Estratégica Siglo XXI

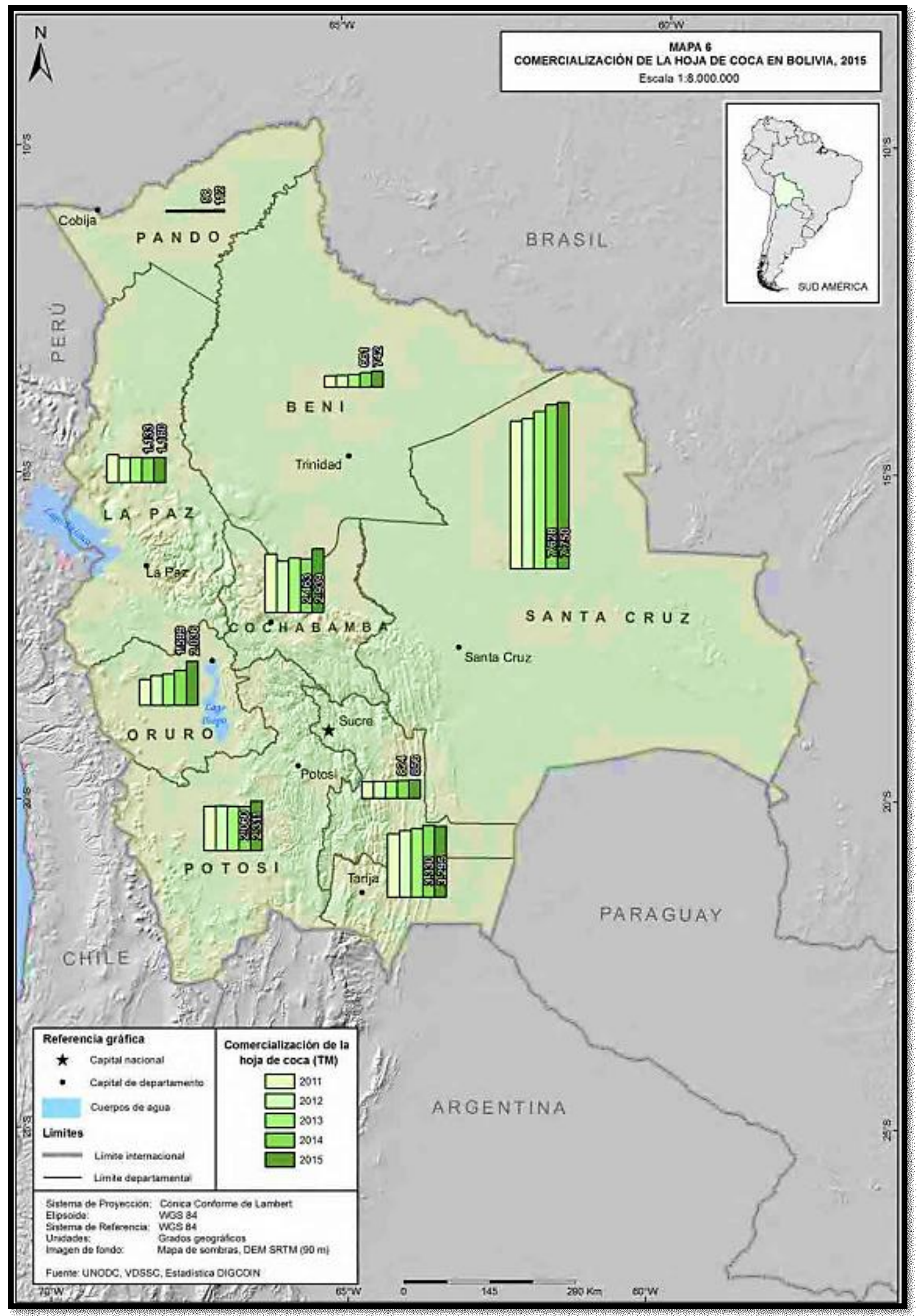

Tesis de Maestría 


\section{RACIONALIZACIÓN/ERRADICACIÓN (R/E) DEL CULTIVO DE COCA EN}

\section{BOLIVIA}

El Gobierno del Estado Plurinacional de Bolivia ha demostrado en los últimos años su compromiso ante la comunidad nacional e internacional para reducir el problema de drogas en el país. En este marco se elaboró la "Estrategia de Lucha contra el Narcotráfico y Reducción de Cultivos Excedentarios de Coca 2011 - 2015” (ELCNyRCEC), la cual se basa en tres pilares: 1) Reducción de la oferta, 2) Reducción de la demanda y 3) Reducción de cultivos excedentarios de coca. El tercer pilar plantea como objetivo estabilizar la superficie de cultivos de coca en 20.000 ha. El Estado Plurinacional de Bolivia delimitará las zonas de producción (ELCNyRCEC, 2011). De acuerdo a los objetivos de reducción de cultivos de coca excedentaria establecidos en la ELCNyRCEC, se racionalizará de forma concertada por lo menos 5.000 ha de cultivos de coca por año, hasta estabilizar la producción en 20.000 ha. Laracionalización está orientada a establecer normas y mecanismos de regulación y control social de la hoja de coca, para evitar el incremento de la producción y el desvío de los excedentes comerciables hacia actividades ilícitas. Asimismo se tiene como meta la prevención de nuevas plantaciones de cultivos de coca.

El Comando Estratégico Operacional "Tte. Gironda” (CEO) es la instancia responsable de la actividad de R/E de cultivos de coca. Desde 2014 implementó una estrategia de trabajo que permite un mejor control territorial. Para ello, incrementó de 20 a 25 los Grupos de Trabajo que han sido desplegados a las zonas de producción de coca excedentaria. La siguiente figuera muestra la relación entre la superficie R/E reportada por el Gobierno de Bolivia y la superficie de cultivos de coca cuantificada a nivel nacional por la UNODC, donde se destaca que a partir del año 2011 la R/E ha originado una disminución efectiva en la superficie de cultivos de coca en el país hasta alcanzar 20.200 ha en 2015. Este resultado es atribuible a las tareas de R/E realizadas por el Gobierno de Bolivia y al abandono de parcelas antiguas de cultivos de coca en la Zona Tradicional de los Yungas de La Paz.

Superficie de racionalización/erradicación y superficie con cultivo de coca, $2005-2015$

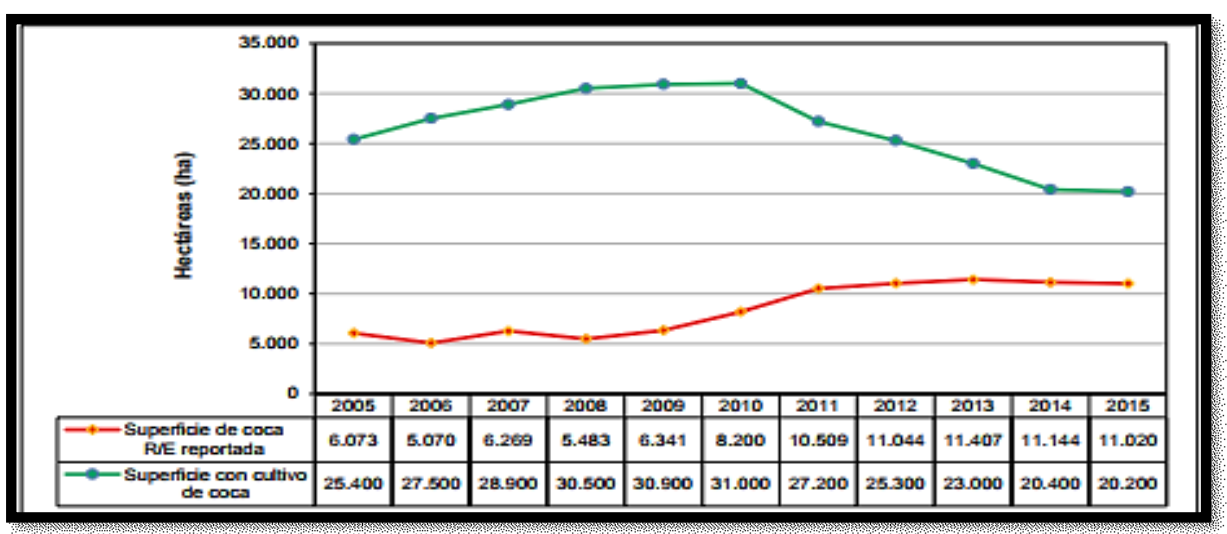

Tesis de Maestría 


\section{INCAUTACIÓN DE HOJA DE COCA Y SUSTANCIAS CONTROLADAS ${ }^{58}$}

La Dirección General de Fuerza Especial de Lucha Contra el Narcotráfico (FELCN) es un organismo especializado de la Policía Boliviana dependiente del Viceministerio de Defensa Social y Sustancias Controladas (VDSSC), que tiene como función realizar la interdicción al tráfico ilícito de sustancias controladas, y en este marco realizar la incautación de las mismas.

En 2015, esta institución incautó 362 toneladas métricas de hoja de coca. Este dato refleja un decremento del 38\% en comparación al año 2014 cuyo valor alcanzó las 582 toneladas métricas. Las incautaciones de hoja de coca a nivel departamental con respecto a 2015, como se observa en la Tabla 15, han disminuido en siete departamentos: Pando, Beni, Oruro, La Paz, Tarija, Cochabamba y Potosí. El único departamento donde se ha registrado un incremento fue en Santa Cruz. En el Departamento de Chuquisaca por segundo año consecutivo no hubo incautaciones de esta sustancia.

Incautación de hoja de coca por departamento, 2005 - 2015 (Kg)

\begin{tabular}{|c|c|c|c|c|c|c|c|c|c|c|c|c|}
\hline Departamento & 2005 & 2006 & 2007 & 2008 & 2009 & 2010 & 2011 & 2012 & 2013 & 2014 & 2015 & $\begin{array}{l}\text { Camblo } \\
2014 \text { - } \\
2015\end{array}$ \\
\hline La Paz & 172.331 & 197854 & 315.463 & 198.829 & 290.394 & 322.013 & 172.134 & 204.585 & 221.330 & 353.671 & 193.351 & $-45 \%$ \\
\hline Cochabamba & 591.803 & 1.030834 & 1.203 .767 & 1.628 .706 & 1.031 .999 & 540.816 & 347.538 & 291.431 & 192.480 & 165.158 & 99.611 & $-40 \%$ \\
\hline Sanla Cruz & 68.508 & 52.018 & 130.703 & 155.464 & 161.244 & 78.027 & 48.896 & 219.573 & 26.170 & 18000 & 51.912 & $188 \%$ \\
\hline Tarija & 18.499 & 19.804 & 11.843 & 21.030 & 20.001 & 37.457 & 7.077 & 1.422 & 4.750 & 2.794 & 1.631 & $-42 \%$ \\
\hline Oruro & 24.814 & 21.913 & 24.393 & 34.075 & 45.674 & 7.076 & 21.746 & 17.877 & 29.120 & 39.752 & 14.905 & $-63 \%$ \\
\hline Potosi & 1.509 & 4010 & 4.999 & 7.149 & 5.764 & 2.655 & 1.034 & 232 & 1.810 & 702 & 670 & $-5 \%$ \\
\hline Chuquisaca & 3.229 & 11.780 & 7.013 & 8.444 & 3.924 & 20.875 & 1.053 & 1.148 & 20 & 0 & 0 & $0 \%$ \\
\hline Beni & 7.525 & 4.778 & 6.768 & 13.076 & 14.959 & 6.058 & 3.843 & 3.536 & 240 & 1.078 & 23 & $-98 \%$ \\
\hline Pando & so & 271 & $6 B 6$ & so & 0 & 58 & 0 & 79 & 70 & 1.025 & 0 & $-100 \%$ \\
\hline Tolal & 886.268 & 1.343 .082 & 1.705 .636 & 2.084 .823 & 1.574 .041 & 1.015 .035 & 603.319 & 739.884 & 475.970 & 582.188 & 362102 & $-38 \%$ \\
\hline
\end{tabular}

Seguidamente ilustraremos las incautaciones de hoja de coca a nivel nacional tienen una tendencia ascendente desde 2005 hasta 2008, cuando alcanzaron su valor más alto de 2.065 toneladas métricas. A partir de 2009 la tendencia es descendente, alcanzando en 2015 un valor de 362 toneladas métricas.

Incautación de hoja de coca en Bolivia, 2005 - 2015

\footnotetext{
${ }^{58} \mathrm{https}$ ://www.unodc.org/documents/crop-monitoring/Bolivia/Bolivia_Informe_Monitoreo_Cultivos_Coca_2015.pdf Tesis de Maestría
} 


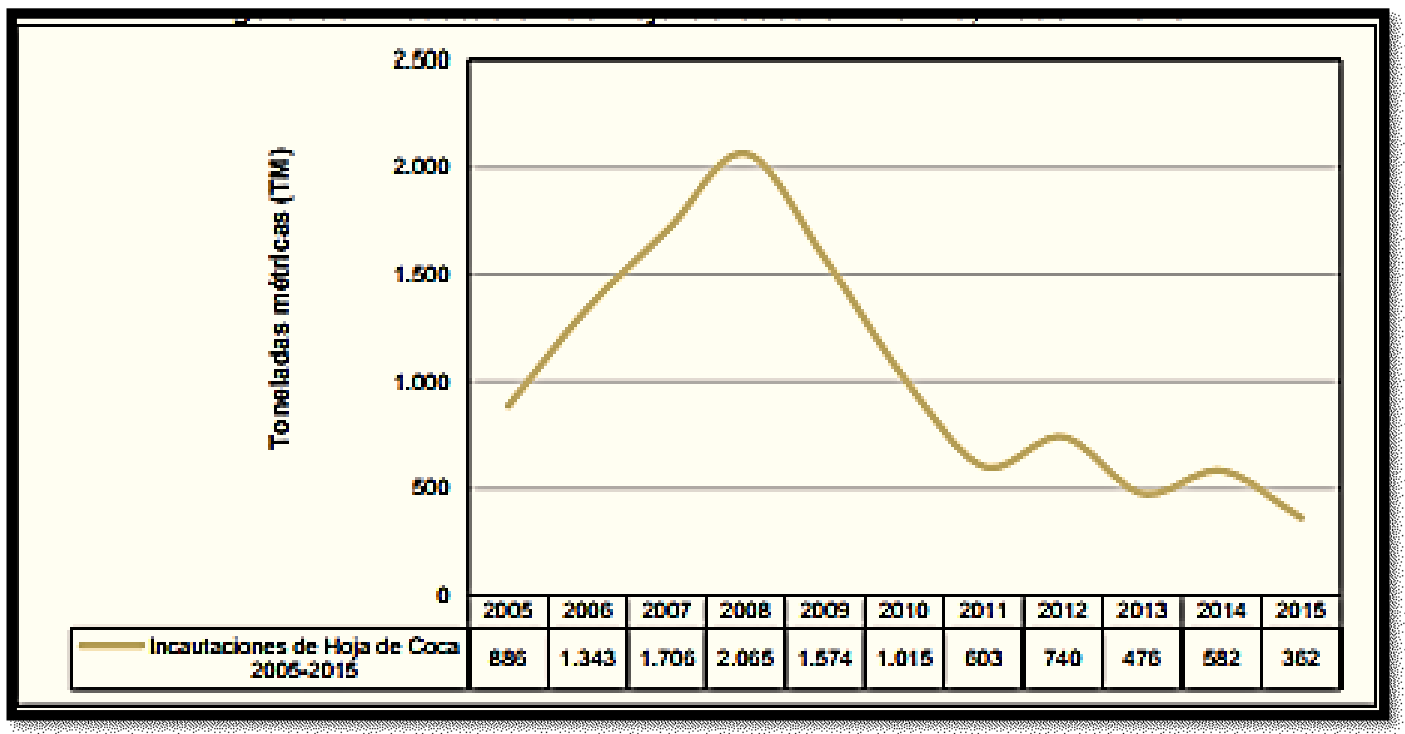

En el siguiente grafico mostramos los porcentajes de hoja de coca incautada en los principales departamentos del país en 2015. El departamento con mayor cantidad de hoja de coca incautada es La Paz con el 53\%, seguido por Cochabamba con 28\% y Santa Cruz con el 14\%.

Incautación de hoja de coca en los principales departamentos de Bolivia, 2015

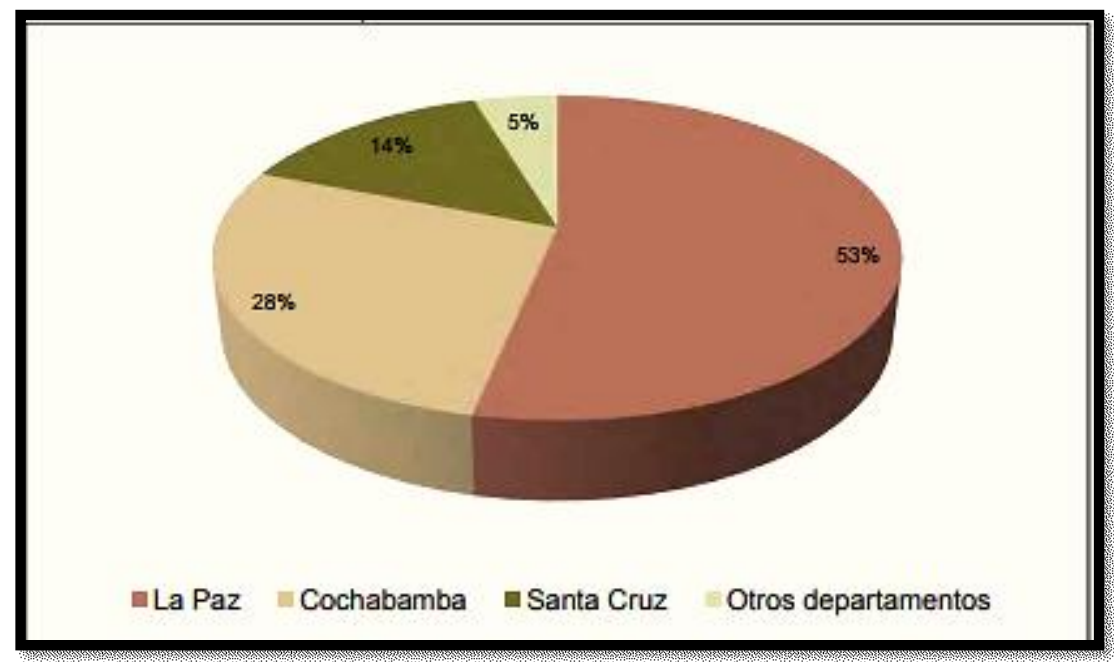

Incautación de cocaína en Bolivia, 2005 - 2015 (TM)

\begin{tabular}{|l|r|r|r|r|r|r|r|r|r|r|r|r|}
\hline \multicolumn{1}{|c|}{ Producto } & 2005 & 2006 & 2007 & 2008 & 2009 & 2010 & 2011 & 2012 & 2013 & 2014 & 2015 & $\begin{array}{c}\text { Cambio } \\
2014-2015\end{array}$ \\
\hline $\begin{array}{l}\text { Cocaína } \\
\text { base }\end{array}$ & 10,15 & 12,78 & 14,91 & 21,64 & 21,97 & 25,71 & 28,35 & 32,13 & 20,41 & 18,26 & 12,68 & $-31 \%$ \\
\hline $\begin{array}{l}\text { Clorhidrato } \\
\text { de cocaína }\end{array}$ & 1,30 & 1,31 & 2,92 & 7,25 & 4,92 & 3,39 & 5,61 & 4,18 & 1,58 & 4,08 & 8,60 & $111 \%$ \\
\hline
\end{tabular}

El Siguiente grafico nos muestra las tendencias de los volúmenes incautados de cocaína base y clorhidrato de cocaína durante el periodo 2005 - 2015. Las incautaciones de cocaína base hasta Tesis de Maestría 
el año 2012 muestran una tendencia creciente, de 10 toneladas métricas en 2005 a 32 toneladas métrica en 2012, a partir de 2013 la tendencia es decreciente llegando a las 13 toneladas métricas en 2015. Por otra parte, las incautaciones de clorhidrato de cocaína revelan una tendencia variable, alcanzando su punto más alto el 2015 en donde se incautaron más de 8 toneladas métricas.

Incautación de cocaína en Bolivia, 2005 - 2015 (TM)

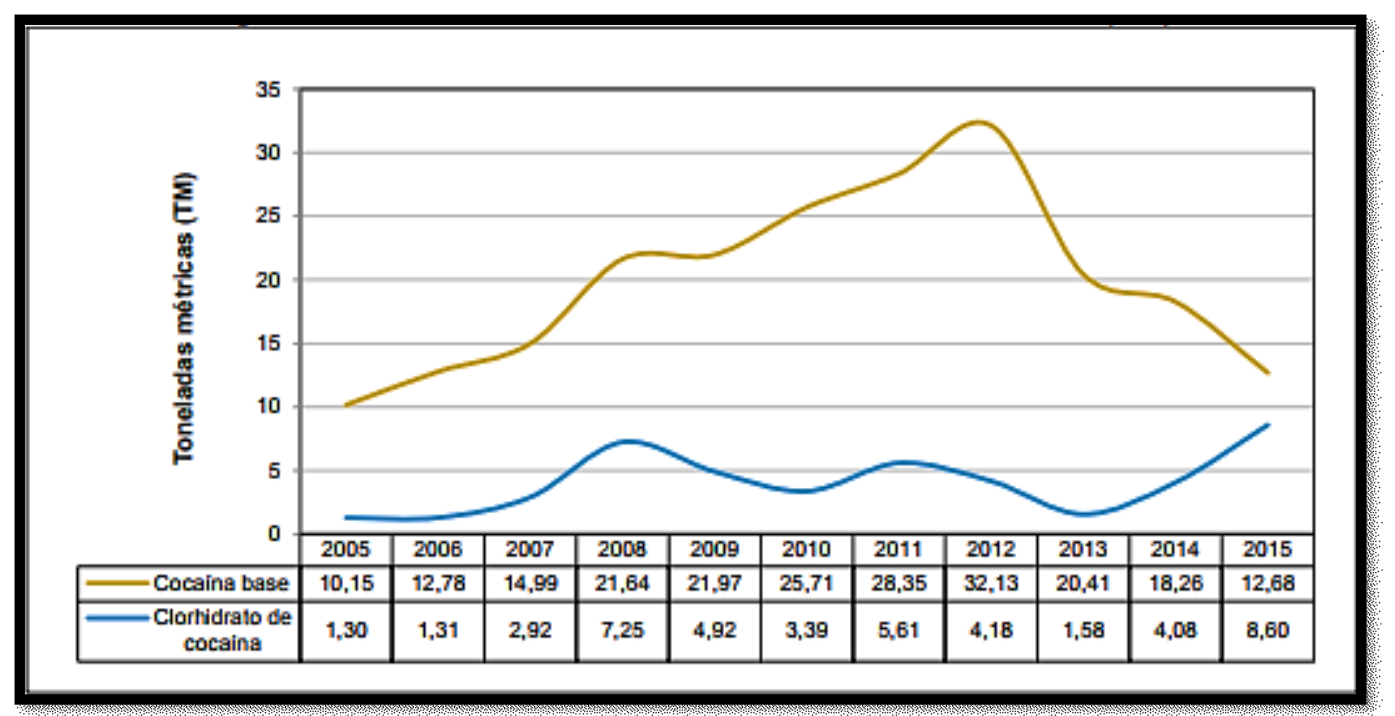

En 2015, en el Departamento de Santa Cruz se incautó la mayor cantidad de clorhidrato de cocaína y cocaína base 7.629 y $4.754 \mathrm{Kg}$ respectivamente, seguido por el Departamento de Cochabamba y Oruro

Incautación de cocaína base y clorhidrato de cocaína por departamentos, 2015

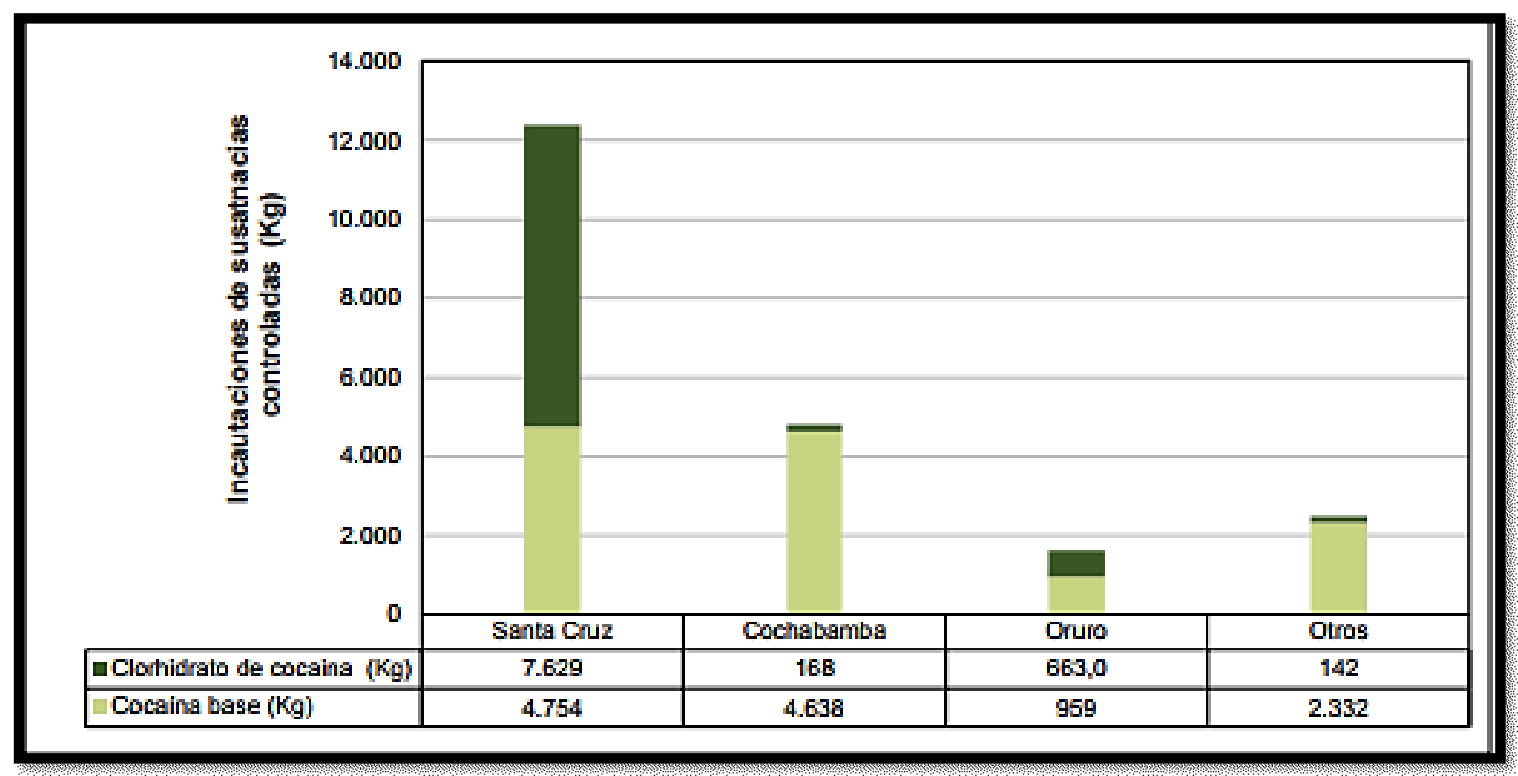

Las incautaciones de sustancias precursoras químicas sólidas y liquidas a nivel nacional disminuyeron en un 8\% y 36\% respectivamente en comparación al 2014 (ver Tabla 17). En Bolivia, los controles e interdicciones de sustancias químicas precursoras son realizadas por el Tesis de Maestría 
Grupo de Investigación de Sustancias Químicas (GISUQ) y la Dirección General de Sustancias Controladas (DGSC)

Incautación de sustancias químicas, 2005 - 2015

\begin{tabular}{|c|c|c|c|c|c|c|c|c|c|c|c|c|}
\hline $\begin{array}{l}\text { Sustancias } \\
\text { químicas }\end{array}$ & 2005 & 2006 & 2007 & 2008 & 2009 & 2010 & 2011 & 2012 & 2013 & 2014 & 2015 & $\begin{array}{c}\text { Cambio } \\
2014- \\
2015 \\
\end{array}$ \\
\hline Sólidas (Kg) & 312.300 & 323.280 & 653.390 & 443.770 & 871.710 & 963.820 & 747.212 & 1.281 .284 & 900.390 & 631.112 & 579.134 & $-8 \%$ \\
\hline Líquidas (lits) & 583.490 & 1.352 .150 & 1.435 .420 & 139.081 & 157.868 & 2.400 .270 & 2.634 .906 & 1.896 .684 & 2.053 .670 & 1.640 .323 & 1.053 .519 & $-36 \%$ \\
\hline
\end{tabular}

La siguiente figura refleja los datos de destrucción de fábricas de cocaína ejecutado por la FELCN, la cual muestra una tendencia variable. Su punto más alto fue el año 2013 donde se destruyeron cerca de 5.930 fábricas. En 2015 se ha destruido 4.234 fábricas de producción de cocaína, un 20\% menos que en 2014. Los operativos de destrucción en su mayoría fueron llevados a cabo en los departamentos de Cochabamba y Santa Cruz ${ }^{59}$.

Destrucción de fábricas de cocaína, 2005 - 2015

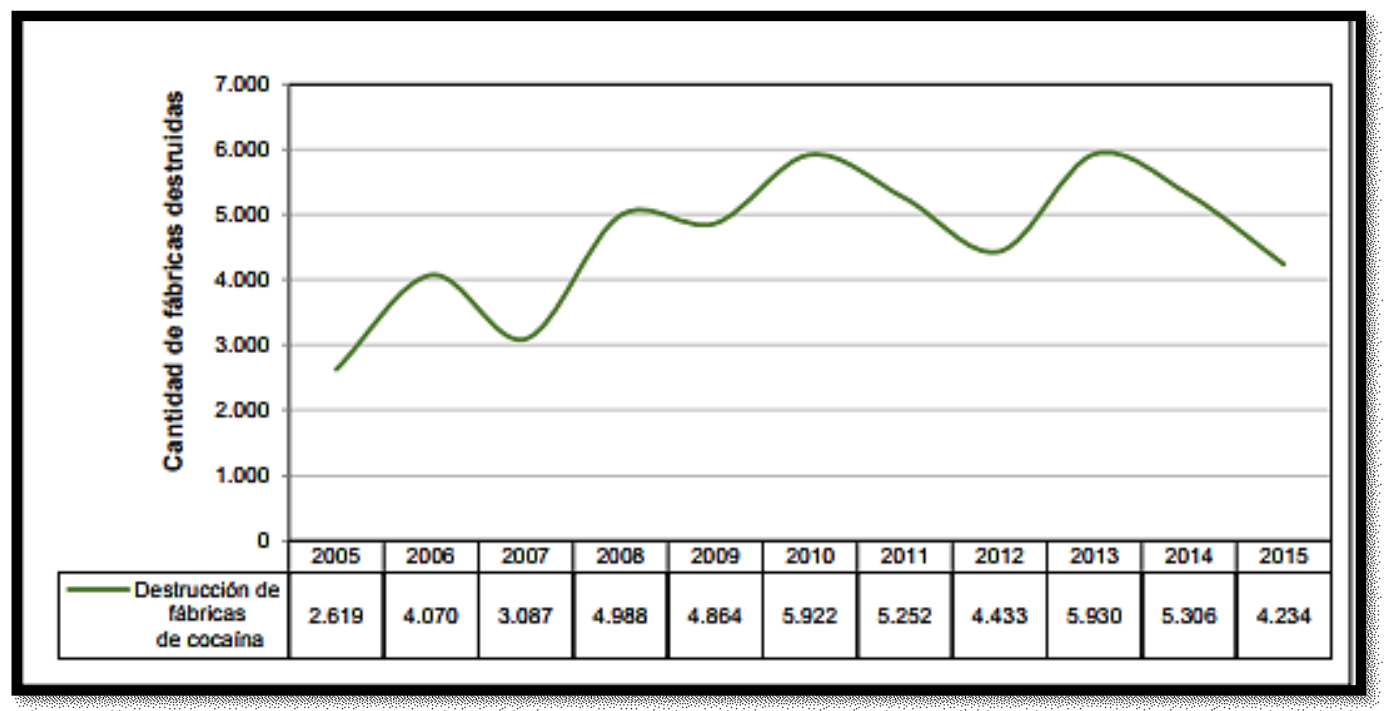

\section{$\underline{B O L I V I A}$, el nuevo epicentro del narcotráfico en Sudamérica $^{60}$}

Al crimen organizado transnacional le gustan las oportunidades y la poca resistencia. Actualmente Bolivia ofrece ambas y se encuentra en el corazón de una nueva dinámica criminal que amenaza la seguridad nacional y ciudadana en este país andino sin salida al mar.

Esta nueva dinámica criminal está centrada en los cambiantes patrones de consumo de drogas en la región. El papel dominante de México en el comercio regional de drogas debe mucho a su ubicación, cerca al consumidor de drogas más grande del mundo, así como a su capacidad para

\footnotetext{
${ }^{59} \mathrm{https} / / /$ www.unodc.org/documents/crop-monitoring/Bolivia/Bolivia_Informe_Monitoreo_Cultivos_Coca_2015.pdf

${ }^{60}$ Jeremy Mac Dermott (2014) "El Desafío de Evo Morales - Bolivia el epicentro de la droga" In Shing Crime http://es.insightcrime.org/investigaciones/bolivia-nuevo-epicentro-narcotrafico-suramerica

Tesis de Maestría
} 
producir drogas como heroína, marihuana y metanfetaminas. Bolivia está muy cerca del que es hoy el segundo mayor consumidor de drogas ilegales del mundo: Brasil. Bolivia también limita con el principal productor de cocaína del mundo, Perú, y con el principal productor de marihuana de Suramérica, Paraguay. Mientras tanto, Argentina está experimentando un aumento en el consumo interno de drogas, en particular de "basuco" o "paco", un tipo de cocaína que se puede producir en Bolivia. En la actualidad, incluso los mercados domésticos de drogas de Chile y Perú están presentando un crecimiento.

Hoy en día Bolivia está literalmente en el corazón del comercio de narcóticos ilegales de Sudamérica. Agregue a esto el hecho de que Bolivia también produce su propia cocaína y se encontrará con una diversidad de oportunidades criminales.

Esta dinámica en Sudamérica es totalmente independiente de las tradicionales rutas de tráfico de drogas que alimentan el mercado de Estados Unidos. De hecho, fuentes estadounidenses consultadas por InSight Crime afirmaron que el análisis químico de la cocaína incautada en Estados Unidos demuestra que sólo el cinco por ciento de ella proviene de Bolivia.Estas dinámicas en sí mismas podrían convertir a Bolivia en un epicentro del tráfico de drogas, pero también hay otros factores que hacen de este país un terreno bastante fértil para el Crimen Organizado Transnacional (COT).

Es importante señalar que Bolivia, con una tasa de homicidios de 11 por cada 100.000 habitantes, es un país seguro para los estándares latinoamericanos. El gobierno del presidente Evo Morales ha registrado un éxito significativo en la lucha contra el tráfico de drogas, principalmente en lo que respecta al control de los cultivos de coca. Sin embargo, los recursos que actualmente están siendo desplegados por el Estado boliviano para enfrentar al COT enfocados en los posibles beneficios económicos del comercio de la droga- han probado no ser suficientes.

\section{$\underline{\text { La naturaleza del crimen organizado boliviano }}$}

Bolivia llegó a contar con sus propios sindicatos de la droga de grandes ligas. El más notorio de éstos estuvo dirigido por Roberto Suárez, conocido como "El Rey de la Cocaína" de Bolivia, quien incluso llegó a trabajar con Pablo Escobar y el Cartel de Medellín. Hoy, el crimen 
organizado en el país está limitado principalmente a los clanes criminales, los cuales participan en una amplia variedad de actividades delictivas, principalmente el contrabando.

En ocasiones, estos clanes involucrados en el tráfico de drogas también participan en la producción de base de coca. Según una fuente de alto nivel en la policía boliviana, el más sofisticado de estos clanes puede reunir hasta 1.000 kilos de base de coca y enviarlos a los grupos del crimen organizado brasileño. Esta base de coca, o base de cocaína, posteriormente alimentará el mercado del "basuco".

El basuco es como la cocaína crack, una forma altamente adictiva de la droga que se fuma. Es más barato de producir que la cocaína y el pico de su efecto es intenso pero de corta duración, haciendo que los adictos lo consuman de manera repetida y prolongada, lo que genera un daño permanente en su salud. Al igual que la epidemia del crack en Estados Unidos en los años ochenta, que dio lugar a la guerra contra las drogas, Brasil, y en menor medida Argentina, ahora están luchando para contener la creciente cantidad de consumidores de basuco. Bolivia es el principal proveedor de ambos países.

Ichilo, en el departamento de Santa Cruz, es uno de los centros de producción de base de coca, y es hogar de al menos cuatro de los más sofisticados clanes bolivianos de la droga. En una entrevista con el programa de televisión boliviana "Sin Letra Chica", un miembro de uno de estos clanes señaló que su organización trabaja en conjunto con otra, y que entre las dos cuentan con unos 600 miembros. En una buena semana los dos clanes pueden producir hasta 800 kilos de base de coca, agregó. Parte de esta cocaína es transportada a la frontera con Brasil, donde se vende directamente a los grupos del crimen organizado brasileño; otra parte es comprada por los colombianos, los cuales procesan la base y la convierten en cocaína. La fuente también dejó claro que el coronel de la policía de la cercana localidad de Yapacaní estaba incluido en la nómina de los narcotraficantes.

Extrañamente hay poca violencia entre los clanes criminales de Bolivia, razón por la cual sus actividades atraen poca atención. A diferencia de los colombianos, y cada vez más de los brasileños, el crimen organizado boliviano prefiere resolver sus diferencias pacíficamente. Parte de esto puede ser explicado desde la fuerza que tiene la cultura indígena en Bolivia, la cual aborrece la violencia y trata de encontrar soluciones comunes a los problemas. Sin embargo hay evidencia de un incremento en los asesinatos relacionados con las drogas en Santa Cruz, aunque 
esto podría estar más vinculado al COT que a las disputas entre los clanes criminales de Bolivia. La Oficina de las Naciones Unidas contra la Droga y el Delito (ONUDD) ha advertido que un aumento en la violencia es casi inevitable si Bolivia mantiene su posición como país productor y punto de tránsito para las drogas.

En marzo de 2013 el gobernador de Santa Cruz declaró estado de emergencia para contener una ola de crímenes en la ciudad, culpando al narcotráfico de la violencia. El tema volvió a los titulares en julio de este año, cuando en el transcurso de dos semanas se presentaron cinco asesinatos en Santa Cruz, en los cuales, presuntamente, habría participado el COT colombiano.

En 2013, el Observatorio Nacional de Seguridad Ciudadana (ONSC) de Bolivia registró 762 pandillas en el país. La mayor parte de ellas concentradas en La Paz (261), Santa Cruz (169) y Cochabamba (106), con más de 25.000 miembros a lo largo del país. Algunas de éstas son simples pandillas callejeras; otras estarían mejor clasificadas como clanes criminales.

\section{El crimen organizado transnacional en Bolivia y el "efecto cucaracha"}

Con la evolución del crimen organizado transnacional latinoamericano se han producido dos acontecimientos que ahora afectan a Bolivia de forma directa.

A pesar de que los colombianos han estado interesados en Bolivia durante unas cuatro décadas, la naturaleza de este interés ha cambiado en los últimos diez años. Pablo Escobar solía llevar a Colombia aviones llenos de base de coca e incluso de cocaína boliviana antes de que la droga siguiera su camino hacia el principal mercado del mundo, Estados Unidos.

Hoy en día son los mexicanos, no los colombianos, quienes dominan el mercado de la cocaína en Estados Unidos. De hecho, en muchos casos, los colombianos se han convertido en proveedores al por mayor de los mexicanos. Mientras que en los días del Cartel de Medellín los colombianos producían un kilo de cocaína por alrededor de US\$2.000 y lo vendían en Estados Unidos por US\$50.000, actualmente la mayor parte de las ganancias terminan en manos de los mexicanos.

En Colombia un kilo de cocaína de alta pureza cuesta alrededor de US\$3.000. Los mexicanos compran a los colombianos ese mismo kilo por entre US\$8.000 y US\$12.000 en Honduras, el principal punto de transferencia. Esto significa que el crimen organizado colombiano gana, en el 
mejor de los casos, alrededor de US\$7.000 por kilo de cocaína, una vez restados los costos de transporte. Los riesgos de interdicción, así como los de extradición a Estados Unidos, son altos. En Bolivia, utilizando base peruana, los colombianos pueden producir un kilo de cocaína de alta calidad por menos de US\$2.000. Ese mismo kilo en Río de Janeiro o Buenos Aires alcanza un valor de hasta US\$8.000. Por lo tanto, los colombianos pueden ganar más de US\$5.000 por kilo, pero con un riesgo mínimo de interdicción y casi ninguno de extradición; simplemente moviendo envíos de drogas a través de la frontera con Bolivia hacia Brasil o Argentina.

Estos dos países también actúan como puntos de transbordo para los mercados más lucrativos de todos: Europa y Asia. Y es aquí donde los colombianos están concentrando sus esfuerzos. En España o en Holanda, los principales puertos de entrada a Europa, un kilo de cocaína tiene un valor de US\$40.000; en el Reino Unido hasta US\$50.000; en Rusia hasta US\$80.000. Mientras que en Tokio ese mismo kilo de cocaína puede alcanzar un valor superior a los US\$100.000.

Hoy en día, el COT colombiano está produciendo cocaína de alta pureza en Bolivia y la está enviando a Brasil y Argentina, donde se vende una parte de la droga y el resto es transportado hacia Europa o Asia. Los colombianos siguen siendo los pioneros en el tráfico internacional de drogas, y la lógica actual del negocio indica que el mercado de Estados Unidos ya no es tan rentable para ellos, pues ahora está dominado por los mexicanos, quienes ganan la porción más grande del tráfico de un kilo de cocaína. Lo anterior hace de Bolivia infinitamente más atractiva para el COT colombiano ${ }^{61}$.

\begin{tabular}{|c|c|}
\hline \multicolumn{2}{|c|}{$\begin{array}{c}\text { Precios de la cocaina enviada al mercado } \\
\text { estadounidense desde Colombia }\end{array}$} \\
\hline$\$ 3.000$ & $\begin{array}{l}\text { Lo que cuesta producir un kilo de cocaína de alta } \\
\text { pureza en Colombia. }\end{array}$ \\
\hline $\begin{array}{l}\$ 8.000- \\
\$ 12.000\end{array}$ & $\begin{array}{l}\text { Lo que pagan los traficantes mexicanos por ese } \\
\text { kilo en Honduras. }\end{array}$ \\
\hline$\$ 7.000$ & $\begin{array}{l}\text { Lo que están ganando las colombianos con alto } \\
\text { riesgo de incautación, como máximo, por kilo. }\end{array}$ \\
\hline \multicolumn{2}{|c|}{ Precios de la cocaína enviada desde Bolivia } \\
\hline$\$ 2.000$ & $\begin{array}{l}\text { Lo que cuesta producir un kilo de cocaína de alta } \\
\text { pureza en Bolivia. }\end{array}$ \\
\hline$\$ 8.000$ & $\begin{array}{l}\text { Lo que cuesta ese kilo en São Paulo y Buenos } \\
\text { Aires. }\end{array}$ \\
\hline$\$ 5.000$ & $\begin{array}{l}\text { Lo que los traficantes Colombianos pueden } \\
\text { ganar por kilo con un mínimo riesgo de } \\
\text { incautación. }\end{array}$ \\
\hline
\end{tabular}

\footnotetext{
${ }^{61}$ Jeremy Mac Dermott (2014) "El Desafío de Evo Morales - Bolivia el epicentro de la droga" In Shing Crime http://es.insightcrime.org/investigaciones/bolivia-nuevo-epicentro-narcotrafico-suramerica Tesis de Maestría
} 
Por otra parte, el llamado "efecto cucaracha" también ha tenido un impacto significativo sobre Bolivia. Cuando las luces se encienden en una habitación, las cucarachas corren hacia los rincones oscuros.

El crimen organizado en gran medida actúa de la misma manera. Las luces están encendidas en Colombia y los barones de la droga, una vez son identificados, tienen una vida útil bastante corta allí, por lo que se trasladan al extranjero. Bolivia todavía no ha podido encontrar su interruptor eléctrico.

A pesar de que durante las redadas a los laboratorios de producción de drogas en Bolivia a menudo se produce la captura de colombianos, la policía boliviana aún no ha conseguido desmantelar estructuras criminales colombianas de un tamaño significativo. Durante una entrevista con un oficial de la policía boliviana de alto nivel, que por razones políticas prefirió el anonimato, el funcionario reveló que actualmente existen tres redes colombianas principales. La más antigua tiene sus raíces en un grupo paramilitar de los Llanos Orientales de Colombia, las Autodefensas Campesinas de Casanare (ACC), alguna vez dirigidas por Héctor Buitrago, alias "Martín Llanos". A finales de los años noventa Buitrago envió unos 300 paramilitares a Bolivia. En junio de 2011 la policía boliviana arrestó a su primo, Carlos Noel Buitrago Vega, alias "Porremacho", en Santa Cruz. En febrero de 2012, Héctor Buitrago fue capturado en Venezuela.

Otros recién llegados incluyen traficantes colombianos tanto de los Rastrojos como de los Urabeños, actualmente dos de las más poderosas estructuras de COT en Colombia.

También hay indicios de que en Bolivia se han establecido "oficinas de cobro" colombianas. Una oficina de cobro es una estructura criminal utilizada para controlar y regular el tráfico de cocaína. La primera oficina de cobro fue la "Oficina de Envigado", una estructura fundada por el Cartel de Medellín de Pablo Escobar. Él utilizó la Oficina de Envigado para mantener control sobre el hampa de Medellín y asegurarse de que todos los traficantes pagaran su cuota a "El Patrón". Las oficinas de Escobar estaban encargadas de recolectar los pagos de los traficantes y otras deudas pendientes, $\mathrm{y}$, cuando era necesario, contrataban sicarios para asesinar a aquellos que se negaban a pagar o que ofendían a Escobar de alguna manera. El modelo llegó a dominar el hampa de Medellín y fue replicado a lo largo de Colombia por medio del ejército paramilitar de las Autodefensas Unidas de Colombia (AUC). Las AUC manejaron la mayor parte del tráfico de drogas en Colombia entre 1997 y 2006, cuando se desmovilizaron. 
Ahora el crimen organizado colombiano ha establecido oficinas de cobro en Panamá, Honduras, Costa Rica, Argentina, Venezuela, Ecuador, Perú, España y Bolivia. En julio la policía de Bolivia capturó a Alicia Lorena Vargas Muñoz, alias "La Mona", una colombiana acusada de dirigir una oficina de cobro en Santa Cruz, que fue vinculada a una serie de asesinatos en la ciudad relacionados con las drogas.

Después de los colombianos, los segundos grupos más poderosos del COT que operan en Bolivia vienen de Brasil. Debido a las diferencias lingüísticas, y tal vez a las culturales, los colombianos no cuentan con las mismas redes criminales en Brasil que, digamos, en Argentina. Los grupos brasileños alimentan el creciente mercado de drogas de Brasil, y para asegurar el suministro de cocaína y sus derivados -y también de marihuana- el COT brasileño ha establecido una presencia permanente en Bolivia y Paraguay.

Los más poderosos grupos de COT de Brasil son el Primer Comando Capital (PCC) y el Comando Vermelho (CV). Fundadas al interior del brutal sistema penitenciario brasileño, estas pandillas ahora controlan gran parte de la venta de drogas en São Paulo y Río de Janeiro, y se han extendido por todo Brasil. Estos grupos han dado el salto al crimen organizado transnacional, y en Bolivia están ubicados principalmente en los departamentos fronterizos de Beni y Santa Cruz. En enero y marzo de 2013 dos células diferentes del PCC fueron desmanteladas en Santa Cruz. El entonces comandante de la Fuerza Especial de Lucha Contra el Narcotráfico (FELCN), el coronel Gonzalo Quezada, señaló que estas células estaban compuestas por "emisarios de alto nivel" del grupo brasileño, enviados para supervisar la compra y el transporte de los cargamentos de droga.

El futuro criminal de Bolivia

Es probable que se solidifique la importancia de Bolivia como epicentro transnacional para el tráfico de drogas. Los mercados de drogas para la cocaína y sus derivados en Suramérica están creciendo y se están diversificando. Es poco probable que la producción de drogas en Perú y Bolivia presente un cambio drástico en el futuro cercano. Perú está intensificando su erradicación de cultivos y planea instalar algunos controles de radar a lo largo de su frontera, mientras que Estados Unidos está a punto de aumentar su ayuda antinarcóticos para ese país. Es probable que esto tenga un impacto negativo y significativo en Bolivia. A pesar de que Morales ha tenido éxito en contener la producción de coca en su país, si disminuye el suministro de base 
barata y de alta calidad de coca de Perú, la presión de los narcotraficantes para conseguir el producto dentro de Bolivia podría aumentar sustancialmente.

La reelección de Morales significa que es poco probable que el estado actual de las relaciones con Estados Unidos cambie. Actualmente no hay presencia de la Agencia Antidrogas de Estados Unidos (DEA, por sus siglas en inglés), y desde mediados de 2013 la Oficina para Asuntos Narcóticos Internacionales y Aplicación de la Ley (INL, por sus siglas en inglés) y la Agencia de los Estados Unidos para el Desarrollo Internacional (USAID, por sus siglas en inglés) han dejado el país. Si bien Bolivia ahora recibe apoyo antinarcótico de la Unión Europea y Brasil, ninguno de ellos cuenta con la experiencia, los recursos o los datos para comenzar a llenar el vacío dejado en la inteligencia estratégica, alguna vez suministrada por Estados Unidos.

El desafío de Bolivia radica en fortalecer sus instituciones y su capacidad policial para poder proporcionar suficiente resistencia al COT, para que así éste se vea obligado a establecer sus operaciones en algún otro lugar. Sin embargo, es poco probable que esto ocurra sin un cambio radical en la estrategia de Morales, que esté acompañado de una gran inversión en recursos. El COT ya está en Bolivia, y entre más raíces logre echar más probable será que consiga penetrar las instituciones del Estado. Ya existe evidencia de que esto está sucediendo en Santa Cruz, tanto en la ciudad como en el departamento. La ciudad está creciendo rápidamente y se está convirtiendo en una metrópolis más grande y sofisticada, con unos 1,5 millones de habitantes. Santa Cruz está desarrollando hoteles de alta calidad, restaurantes, vida nocturna y apartamentos de lujo, elementos que los traficantes de drogas de alto nivel encuentran atractivos en una base de operaciones.

Aunque los traficantes de alto nivel todavía prefieren residir en Buenos Aires, sobre todo los colombianos, Santa Cruz está en pleno auge. Esto podría cambiar la posición actual de la ciudad como epicentro para la negociación de la compra y el transporte de alijos de droga, y convertirse en un atractivo lugar de residencia. En el caso de que los narcos de alto nivel comiencen a vivir allí, esto no sólo acelerará el proceso de corrupción de las instituciones policiales y judiciales, sino que muy probablemente también buscarán influenciar la arena política.

Hay que recordar que los mexicanos comenzaron en el negocio de la cocaína como transportadores de los colombianos y hoy dominan el mercado de cocaína en Estados Unidos. Cuanto más tiempo Bolivia siga actuando como país de producción y transbordo de drogas, 
mayor será la probabilidad de que los grupos del crimen organizado bolivianos evolucionen en organizaciones transnacionales sofisticadas. Sin una inversión significativa en la lucha contra el narcotráfico y el COT, el pronóstico para Bolivia sólo puede ser pesimista.

\section{0 razones por las cuales Bolivia es un potencial paraíso para el razones por las cuales}

Es importante señalar que InSight Crime no cree que Bolivia haya sido tomada por el crimen organizado transnacional (COT), y ni siquiera está cerca de serlo. Sin embargo, el país es vulnerable y actualmente las oportunidades y el potencial de ganancias del narcotráfico son demasiado altos como para que los grupos criminales internacionales lo ignoren.

1. Cultivos de drogas. Bolivia no es sólo un país de tránsito de drogas sino también una nación productora de coca y cocaína. Aunque el presidente Morales ha logrado reducir los cultivos de coca en los últimos tres años, cada vez va a ser más difícil contenerlos.

Las razones de esto se deben en parte a las continuas campañas de erradicación, tanto en Colombia como en Perú. Colombia, el único país que permite la erradicación aérea de cultivos de droga con glifosato, ha logrado estabilizar el cultivo de coca a un poco menos de 50.000 hectáreas, aunque con daños colaterales significativos. Perú, bajo el presidente Ollanta Humala, ha puesto la erradicación en el centro de su estrategia de lucha contra las drogas, erradicando más de 22.000 hectáreas en 2013, casi el número total de hectáreas de coca cultivada en Bolivia. El "efecto globo" -que se refiere al desplazamiento de la producción de droga a diferentes países en respuesta a la represión que se ejerce en otros- implica que es probable que aumente la presión para cultivar más coca en Bolivia, siempre y cuando se mantenga constante la demanda. Por el momento, Perú exporta alrededor de 200 toneladas de base de coca a Bolivia al año, algunas de las cuales alimentan los mercados domésticos de cocaína crack (o "basuco") de Brasil y Argentina, y el resto de la base de coca es procesada y convertida en cocaína. Si hubiera una significativa caída en el suministro de base de coca peruana, debido a los mayores esfuerzos de erradicación en Perú, lo más probable es que las operaciones de tráfico de drogas en Bolivia promuevan y aumenten la siembra de cultivos de droga a nivel local.

2. Corrupción. Existe evidencia de la corrupción generalizada que hay en muchas de las instituciones de Bolivia, como la policía. En 2011, Estados Unidos diseñó la detención del ex zar antidroga de Bolivia, el general de la policía René Sanabria, en Panamá. Sanabria fue 
posteriormente condenado a 15 años de prisión por un tribunal de Miami tras declararse culpable de tráfico de cocaína.

Fuentes dentro de la Fuerza Especial de Lucha Contra el Narcotráfico (FELCN) dijeron a InSight Crime que la corrupción relacionada con las drogas no terminó con Sanabria y que elementos de la policía aún estaban trabajando con traficantes de drogas. Jessica Echeverría, diputada de la Asamblea Legislativa, quien perteneció a la oposición antes de pasarse este mes al partido gobernante, el Movimiento Al Socialismo (MAS), dijo a InSight Crime que "la policía está trabajando con narcotraficantes colombianos aquí en Santa Cruz". Fuentes del hampa en Santa Cruz confirmaron esto, diciendo que los funcionarios de alto rango de la policía estaban en la nómina de los narcotraficantes y el crimen organizado.

Abogados de defensa criminal en Santa Cruz, que hablaron con InSight Crime bajo condición de anonimato, insistieron en que el sistema judicial también estaba abierto al soborno.

"Los costos están entre US\$20.000 y US\$50.000 para poder quedar libre de todo, aparte de los casos de más alto perfil, y se dividen entre los fiscales y el juez", dijo uno de los abogados.

Una fuente de alto rango en la FELCN dijo que había un alto nivel de frustración con el sistema de justicia. "Traficantes de drogas regulares que hemos capturado quedan libres debido a la ineficiencia judicial o a la corrupción. Incluso ha habido casos en los que bienes y dinero que confiscamos son devueltos por los jueces a los acusados que han sido atrapados in fraganti", dijo. El sistema penitenciario de Bolivia también es totalmente corrupto. InSight Crime consiguió entrar en la prisión más infame de Bolivia -Palmasola en Santa Cruz- simplemente sobornando a la policía en la puerta. Los criminales son capaces de operar con impunidad en Palmasola, y continuar llevando a cabo actividades ilegales.

3. No hay control sobre el espacio aéreo. Los narcotraficantes siempre prefieren mover los envíos por vía aérea, si es posible. Los aviones pueden mover grandes volúmenes de envíos, y las drogas pasan a través de muy pocas manos, lo que reduce los costos, así como los riesgos de traición o incautación. La ruta favorita del Cartel de Medellín para mover drogas a Estados Unidos fue a través del Cayo Norman en el Caribe, donde las flotas de aviones llegaban desde Colombia para abastecerse de combustible y continuar el viaje a Estados Unidos. Sin embargo, la instalación de estaciones de radar a través de Colombia y el despliegue de aviones de 
combate para interceptar vuelos cargados con drogas -y si es necesario para derribarlos- cerró rápidamente el puente aéreo desde Colombia.

Sin embargo, Perú, Bolivia, y Paraguay tienen poca cobertura de radar y casi ningún activo de interdicción $^{62}$ aérea, lo que significa que el cielo está completamente abierto. Este es un factor importante que hace de Bolivia un centro de tráfico de drogas y una gran atracción para el COT. El coronel Marcos Encinas, subdirector de la FELCN, dijo a InSight Crime que creía que hasta 30 toneladas de droga (incluyendo envíos de marihuana) transitaban a través de Bolivia todos los meses.

Bolivia está consciente del tráfico aéreo que pasa sin ser molestado sobre su territorio. El 22 de abril de 2014, el presidente Evo Morales firmó la "Ley de Seguridad y Defensa del Espacio Aéreo Boliviano" que permite el derribo de vuelos con drogas. Pero debido a que Bolivia carece de radares para rastrear este tipo de vuelos y de los aviones de combate para interceptarlos, la ley es poco más que una declaración de intenciones.

Tanto Brasil como Argentina tienen un mejor control sobre su espacio aéreo, pero todavía existe un tráfico aéreo importante hacia ambos países, algunos legalmente declarados y otros probando suerte. En Brasil, para minimizar el riesgo de interdicción, algunos pilotos que cruzan desde Bolivia emplean una táctica conocida como "bombardeo". Esto implica empacar las drogas en contenedores especiales y de alto impacto que puedan sobrevivir a una caída desde un avión en vuelo. Esto permite que la aeronave no necesite aterrizar para bajar la carga, lo que reduce significativamente el riesgo de interceptación e incautación del preciado cargamento.

Sabino Mendoza, el coordinador del máximo organismo gubernamental en la lucha contra el tráfico ilícito de drogas y sustancias controladas, conocido como CONALTID, dijo a InSight Crime que el país ya está tomando medidas para mejorar su capacidad para abordar el tránsito de drogas. El gobierno está planeando implementar varias plataformas móviles de radar en áreas clave donde se concentra el tráfico de drogas, principalmente en los departamentos de Beni, Santa Cruz y Pando. Mendoza también dijo que el gobierno está en conversaciones con Brasil sobre el uso, y potencial adquisición, de aviones no tripulados (o drones) para detectar laboratorios de drogas -éstos emiten señales de calor debido a su uso de generadores y hornos microondas. Sin embargo, no hay una fecha clara para la compra de dichos equipos, por no

\footnotetext{
${ }^{62}$ Acción policial o militar orientada a eliminar cultivos de coca, fiscalizar e investigar el tráfico de químicos esenciales, localización y destrucción de centros de procesamiento de drogas ilícitas, control, incautación o destrucción de infraestructura o medios de transporte utilizados para el TID, desarticulación de las organizaciones dedicadas al TID, investigación y denuncia de narcotraficantes, lucha contra el enriquecimiento ilícito y el ocultamiento o lavado de recursos provenientes del TID Tesis de Maestría
} 
hablar de su despliegue, por lo que parece que los traficantes tendrán varios años más de cielos despejados.

4. Debilidad de los cuerpos de seguridad contra los riesgos que presenta el COT. Esto no es sólo debido a la corrupción de los cuerpos de seguridad bolivianos, incluida la policía, la Fiscalía General y el sistema judicial, sino también debido al hecho de que los agentes judiciales bolivianos, simplemente no tienen los instrumentos jurídicos necesarios para librar una guerra efectiva contra el COT.

La policía carece de dos de las herramientas más importantes utilizadas por los cuerpos de seguridad internacionales. El primero es la capacidad de interceptar las comunicaciones. Esto es ilegal en Bolivia, sin planes para aprobar una legislación que lo permita. Tampoco hay una legislación que disponga los términos para el tratamiento de los informantes, lo que significa que la policía y los fiscales no pueden recompensar a los posibles informantes con dinero o con reducciones de penas de prisión. Una fuente de la Agencia Antidrogas de Estados Unidos (DEA, por sus siglas en inglés) en Colombia dijo a InSight Crime que sin estas dos herramientas para combatir el crimen organizado, la DEA tendría que "hacer las maletas y volver a casa".

Los cuerpos de seguridad bolivianos tampoco cuentan con capacidad de inteligencia sobre el crimen organizado nacional, por no hablar del COT. Para el coronel retirado de la policía Rolando Fernández Medina, la oportunidad clave para el COT vino con la salida de los últimos agentes de la DEA de Bolivia, expulsados por el presidente Morales, en 2009. Esto terminó tres décadas de presencia de la DEA en Bolivia. Con la salida de la agencia se fue toda la inteligencia estratégica sobre el COT, además de la mayor parte de la capacidad de recolección de inteligencia dentro de Bolivia. Aunque la Unión Europea (UE) y los brasileños han estado suministrando ayuda antinarcóticos, ellos simplemente no tienen la misma experiencia o inteligencia de la DEA.

5. Falta de controles de lavado de dinero. El lavado de dinero también es relativamente sencillo en Bolivia. El Grupo de Acción Financiera Internacional (GAFI), un organismo intergubernamental, retiró en 2013 a Bolivia de su "lista gris" de países que no están haciendo lo suficiente para combatir el crimen, después de que el Congreso aprobara una legislación básica contra el lavado de dinero. Sin embargo, casi no hay controles sobre el sistema bancario. 
Sólo se han abierto un puñado de investigaciones sobre lavado de dinero y han habido aún menos condenas.

"Pedro", un traficante de drogas en Santa Cruz, dijo a InSight Crime que él había sido testigo de delincuentes internacionales que llegaban a las empresas constructoras con maletas llenas de dinero en efectivo, y que el lavado de dinero en Bolivia era a menudo así de simple.

6. Cultura de la informalidad y la ilegalidad. Más de la mitad de la actividad económica de Bolivia se lleva a cabo en el sector informal, y a menudo ilegal. El contrabando ha sido durante mucho tiempo el alma de las comunidades a lo largo de las cinco porosas fronteras de Bolivia y esta industria ilegal emplea a muchos más bolivianos que el tráfico de drogas. De hecho, el contrabando es una industria ilegal tolerada. Los autos de contrabando -muchos robados en Chile-constituyen un alto porcentaje de los que se conducen por las carreteras de Bolivia.

Esta cultura implica que hay pocos o ningún reporte de la actividad económica, ilegal o no, a las autoridades. Muchas comunidades locales, no sólo a lo largo de las fronteras, viven del sector informal o ilegal. Esto significa que estas comunidades tienen un gran interés en proteger la economía negra, lo que hace extremadamente difícil el trabajo de los cuerpos de seguridad. Incluso ha habido ejemplos de comunidades locales que se enfrentan a las fuerzas de seguridad que intentan reprimir el tráfico de drogas. En la comunidad de Yapacaní, en el departamento de Santa Cruz, hubo protestas sostenidas contra la construcción de una base antinarcóticos.

7. Apertura de las fronteras y falta de controles migratorios. Las porosas y largas fronteras de Bolivia (con 3.420 kilómetros, la frontera entre Bolivia y Brasil es $200 \mathrm{~km}$ más larga que la que México comparte con Estados Unidos) y la falta de controles migratorios, garantizan que Bolivia sea un centro de contrabando y por lo tanto extremadamente atractivo para el COT. Las fronteras porosas implican que no sólo las drogas se pueden mover hacia adentro y hacia afuera del país, sino que también los precursores químicos y la mano de obra extranjera necesaria para procesarlos. Los criminales internacionales, incluso los que tienen órdenes nacionales de arresto, también pueden moverse hacia adentro y hacia afuera de Bolivia con suma facilidad.

El jefe de la autoridad migratoria de Bolivia, Cosset Estenssoro, reveló que Bolivia no tiene información sobre órdenes nacionales de arresto, sino sólo aquellas órdenes internacionales registradas con la Interpol. Esto significa que los narcotraficantes colombianos con órdenes 
nacionales de arresto pueden entrar en Bolivia sin temor a ser detenidos, algo confirmado por fuentes del hampa en Medellín.

A InSight Crime se le ofreció un pasaporte boliviano genuino por fuentes del hampa en Santa Cruz por US\$5.000, lo que sugiere que conseguir papeles falsos en Bolivia para los narcotraficantes que son buscados por las autoridades tampoco es un gran desafío.

8. Falta de presencia del Estado en muchas zonas rurales. Bolivia, con más de $1.000 .000 \mathrm{~km}^{2}$ de territorio y una población de menos de 11 millones de personas, tiene vastas extensiones del país con poca población y sin presencia del Estado. Esto proporciona una gran cantidad de oportunidades para el COT. Muchos de los laboratorios donde se procesa la cocaína están situados en zonas remotas, con pistas de aterrizaje clandestinas que no sólo proporcionan drogas, sino también productos químicos, personal y los suministros necesarios para procesarlas. Esto reduce significativamente el riesgo de encontrar y destruir laboratorios, y garantiza que las drogas puedan ser procesadas y transportadas con relativa facilidad. Esto también significa que los criminales internacionales, tal vez a la fuga, puedan esconderse en ranchos y granjas remotas con poco temor de ser descubiertos.

9. Falta de transparencia, politización de las instituciones estatales y restricciones a la cobertura de los medios. El ambiente político en Bolivia es uno de gran polarización, algo que ha continuado, si no empeorado, durante el gobierno de Morales. InSight Crime habló con varios oficiales de alto rango de la policía, todos los cuales tenían miedo de ser grabados, quienes afirmaron que la promoción dentro de la fuerza policial en los rangos más altos depende de la afiliación política, no del mérito. Fuentes en otros tres ministerios señalaron que el mismo fenómeno estaba presente en sus instituciones gubernamentales.

Hay muy pocas estadísticas disponibles por parte del gobierno. Las investigaciones de InSight Crime sugieren que esto no es debido a que el gobierno está tratando de ocultar información, sino porque los datos simplemente no están siendo recolectados. Esto significa que hay pocos indicios de los desafíos a la seguridad nacional y ciudadana, por no hablar de la información necesaria para realizar análisis significativos y diseñar políticas detalladas e integrales.

También hay poca tradición de periodismo investigativo en el tema del crimen organizado, y no ha habido incidentes del gobierno presionando a los periodistas. En 2010, Morales promulgó una 
ley que buscaba abordar la representación de los indígenas en los medios de comunicación, pero ha sido utilizada para presionar a los medios a adoptar la línea oficial.

10. Falta de una estrategia integrada para hacer frente al crimen organizado transnacional. CONALTID, bajo Sabino Mendoza, está tratando de armar una estrategia para enfrentar el tráfico internacional de drogas. Si bien se están implementando algunas medidas, incluyendo la reactivación del Observatorio Boliviano de Drogas (OBD), una estrategia integrada de lucha contra el narcotráfico -una que incluya niveles realistas de financiación- aún está en pañales.

La UE ha dado su apoyo al gobierno de Bolivia, buscando compensar algo del déficit con la pérdida de dinero de USAID. InSight Crime habló con el representante de la UE Nicolaus Hansmann en La Paz, quien dijo que la UE había adoptado un "enfoque diverso, teniendo en cuenta el país, y basado en la evidencia", que incluye la sustitución de cultivos, la capacitación de la policía y el apoyo a la investigación financiera.

Sin embargo, este proceso también se encuentra todavía en sus primeras etapas, y está claro que en la actualidad hay pocos obstáculos serios para el funcionamiento del COT en Bolivia ${ }^{63}$.

\section{$\underline{\text { Revelaciones de un productor de base de coca }}$}

Los siguientes son extractos de una entrevista conducida por Sin Letra Chica, un programa de televisión de Carlos Valverde, con un miembro de un clan criminal de Bolivia con sede en San Germán. Los extractos son reproducidos con el permiso de Carlos Valverde y con el agradecimiento de InSight Crime.

¿De dónde viene la coca que ustedes procesan para convertir en droga?

La coca proviene en su mayor parte de Chapare, de Bulo Bulo (Cochabamba), Entre Ríos (Tarija) y de Ivirgarzama (Cochabamba). El flujo es constante. Estamos hablando de una semana normal, sólo hablando sobre mi grupo, ellos nos envían coca cada sábado y domingo. Hay intermediarios que son proveedores permanentes y otros que envían ocasionalmente. La coca llega en paquetes [grandes bolsas de coca conocidas localmente como "chanchos"], mínimo 7, pero los que vienen del área de La Paz pueden llevar entre 350 y 400 paquetes en cada viaje.

\footnotetext{
63 Jeremy Mac Dermott (2014) "El Desafío de Evo Morales - Bolivia el epicentro de la droga" In Shing Crime http://es.insightcrime.org/investigaciones/bolivia-nuevo-epicentro-narcotrafico-suramerica Tesis de Maestría
} 
Algunos paquetes están marcados con las siglas DIGCOIN [Dirección General de la Hoja de Coca e Industrialización, lo que significa que la coca ha sido registrada legalmente], especialmente aquellos que provienen de La Paz, mientras que el resto si es ilegal.

¿Sólo producen base de coca, o también cocaína refinada?

Nosotros producimos la pasta base de la coca; otros grupos refinan la cocaína.

¿Cómo mueven las drogas hacia el mercado?

Aeronaves que aterrizan en la zona. Y mientras nosotros, los trabajadores, cargamos, los hombres que llegan en la aeronave, a quienes a menudo hemos visto antes, se montan en los carros que esperan para ir y hablar con nuestros jefes. A ellos no los hemos visto antes y por lo general son brasileños. Estamos hablando de entre 25 y 30 minutos el tiempo que nos toma cargar las aeronaves. Mientras esto sucede, hay un grupo protegiendo la entrada a la zona y también hay otro grupo mucho más cerca.

¿Qué hacen si uno de ustedes, por alguna razón, es detenido por la policía?

Si es alguien de nuestro grupo, y si es detenido aquí en la zona de Yapacaní por la policía, será liberado en el momento que ellos sepan que es de nuestro grupo. Sin embargo, si la persona es detenida por el FELCN (Fuerza Especial de Lucha Contra el Narcotráfico) en otro lugar, usualmente les toma dos días arreglar su liberación. Algunas veces uno de nosotros es detenido, digamos por una pelea, por estar en estado de embriaguez o lo que sea, o en algunos casos es por vender pequeñas cantidades de drogas; estamos hablando de entre 300 y 500 gramos que puedes vender en Yapacaní. Si la policía se entera, entonces serás detenido y llevado a una estación de la policía. Allí es cuando nuestro jefe llama al coronel, y el coronel se encarga de que nos liberen.

¿Hay algún control sobre el movimiento de ustedes por la zona? ¿Pueden moverse libremente?

"No podemos salir. La forma de control es que ahora una persona nos vigila; un colombiano que se mueve en una moto. Cuando no estamos trabajando él pasa por mi casa, y la casa donde la mayoría de este grupo trabaja. Él pasa en la mañana y tenemos que estar ahí, para que él nos vea. No dice nada, pasa, y regresa en la tarde y tenemos que estar ahí también para que nos pueda ver. 
¿Y si no están allí?

Nos han dicho que si no vamos a estar por ahí tenemos que decir a dónde vamos y con quién vamos a estar. Podemos salir con otros miembros del grupo, pero sólo por poco tiempo, digamos un día, y cuando lo hacemos nos prestan un vehículo. Nos han dicho que si no estamos por ahí, nos pueden castigar de diferentes maneras. Nos han amenazado diciéndonos que podemos desaparecer, que nos pueden matar, o que podemos dejar de recibir dinero.

¿Y usted cómo se siente al respecto?

Con miedo, con miedo de que se la tomen contra mí o contra mi familia. Tengo miedo en el momento porque hay problemas entre dos grupos, y los colombianos que los están dirigiendo tienen mucho control y hay personas que dicen que pueden asesinarte. Ha habido casos de personas que se van a pescar y los matan a la orilla del río.

Usted ha dicho que hay cuatro grandes grupos que controlan esta zona, y también ha mencionado que en ocasiones se presentan problemas entre ellos. ¿Por cuántas personas están compuestos estos grupos? ¿Qué tanto producto están produciendo?

Bueno, pues dos de los grupos sobre los que conozco pueden sumar unos 600 entre ellos, sin embargo, eso puede depender de la cantidad de trabajo que haya. Digamos que puede haber entre 450 y 500 trabajadores, la mayoría de los cuales son de aquí cerca. Los que no, alquilan habitaciones en las casas que hay aquí. En cuanto a la producción, en una buena semana cada grupo puede producir entre 600 y 800 kilos.

Usted ha dicho que hay cuatro personas que mandan los grupos aqui, y que hay uno [lider] que está sobre ellos.

Sí, hay uno sobre ellos, y usualmente solo viene una, tal vez dos, veces al año a la zona.

¿Esa persona tiene alguna posición politica, administrativa u oficial? 
Sí, tiene una posición política. Él es algún tipo de ministro. Nosotros sólo lo hemos visto a la distancia, pero sabemos cómo se ve por la televisión ${ }^{64}$.

\section{FUERZAS ESPECIALES DE LUCHA CONTRA EL NARCOTRAFICO ${ }^{65}$ :}

La Fuerza Especial de Lucha Contra el Narcotráfico, organismo especializado de la Policía Boliviana, desde su creación cumple con la misión asignada en la lucha contra este flagelo de la humanidad, demostrando capacidad e idoneidad en sus delicadas funciones, en base a la dedicación, esfuerzo y entrega total de sus efectivos. Su accionar ha permitido importantes resultados, desbaratando organizaciones criminales dedicadas a esta ilícita actividad, realizando tareas de interdicción en la fabricación, transporte, comercialización de narcóticos y sustancias controladas y afectando de manera significativa en el capital ilegal del narcotráfico.

Su propósito es defender y proteger a la sociedad de la problemática de las drogas ilícitas y hacer cumplir el marco normativo; con la participación social, respeto a los derechos humanos y protección del medio ambiente.

El 7 de enero de 1972, por Resolución Especial, el Comando de la Policía Nacional crea la Oficina de Narcóticos y Drogas Peligrosas dependiente de la Dirección General de la Guardia Nacional. A fin de perfeccionar su funcionamiento en el ámbito nacional, por Resolución No. 3/73, de 7 de marzo de 1973, pasa a depender del Comando General de la Policía Nacional, organizándose por primera vez Oficinas Departamentales de Narcóticos y Sustancias Peligrosas. Por Decreto Ley No. 11245 del 20 de diciembre de 1973, pasa a depender del Ministerio del Interior y toma el nombre de Dirección Nacional de Narcóticos y Sustancias Peligrosas. Posteriormente, la Dirección Nacional de Sustancias Peligrosas pasa a depender del Comité Nacional de Lucha Contra el Narcotráfico que se había creado por D.S. 19846, organismo que dependía directamente de la Presidencia de la República. Sin embargo, en 1985 de conformidad a la Ley Orgánica de la Policía Nacional, vuelve a estar bajo el mando de la institución del Verde Olivo como parte de su Estado Mayor, aspecto que se reglamentó mediante D.S. 20811 de 21 de mayo de 1985.

\footnotetext{
${ }^{64}$ Jeremy Mac Dermott (2014) "El Desafío de Evo Morales - Bolivia el epicentro de la droga” In Shing Crime http://es.insightcrime.org/investigaciones/bolivia-nuevo-epicentro-narcotrafico-suramerica

${ }^{65} \mathrm{http}: / /$ www.felcn.gob.bo/Q-MisionVision.aspx

Tesis de Maestría
} 
Luego de varios cambios estructurales y de dependencia, mediante el Artículo 4to. del Decreto Supremo No. 21666 de 24 de julio de 1987, se constituye la Fuerza Especial de Lucha Contra el Narcotráfico (FELCN). Reglamentando el Título IV de la Ley 1008 del Régimen de la Coca y Sustancias Controladas, el Artículo 25 del D.S. 22373 del 21 de noviembre de 1989, dispone que la FELCN dependa del Ministerio del Interior, Migración y Justicia, hoy Ministerio de Gobierno, a través de la Secretaría Nacional de Defensa Social, hoy Viceministerio de Defensa Social y

Sustancias Controladas. Asimismo, por Resolución Ministerial No. 2669 de fecha 3 de noviembre de 1995, dictada por el Ministerio de Gobierno, se dispuso la reestructuración de la FELCN, misma que fue materializada mediante Resolución Suprema No. 216628 del 5 de marzo de 1996. Actualmente, el Gobierno del Estado Plurinacional de Bolivia ha orientado sus esfuerzos a la nacionalización de la lucha contra el narcotráfico, enmarcándolos en la Estrategia de Lucha Contra el Narcotráfico y Reducción de Cultivos Excedentarios de Coca 2011-2015. La Fuerza Especial de Lucha Contra el Narcotráfico, fiel a su doctrina institucional, reafirma su compromiso de servicio incondicional a la sociedad a través de la dignificación de la lucha antinarcóticos, en el marco de los principios y valores establecidos por las normas en actual vigencia y en cumplimiento al Mandato Presidencial de servir al pueblo boliviano, con honestidad, lealtad, humildad y abnegación.

\section{${\underline{\text { Estadísticas sobre procedimientos de la FELCN durante el } 2015^{66}}}^{6}$}

\footnotetext{
${ }^{66} \mathrm{http}: / /$ www.felcn.gob.bo/R-Estadisticas.aspx Tesis de Maestría
} 
Cuadro Comparativo por Departamentos Gestión 2015

\begin{tabular}{|c|c|c|c|c|c|c|c|c|c|}
\hline DESCRIPCION & LAPAZ & COCHABAMBA & SANTA CRUZ & ORURO & POTOSI & CHUQUISACA & TARIIA & BENI & PANDO \\
\hline OPERATIVOS REALIZADOS & 3.551 & 5.171 & 2.440 & 226 & 135 & 136 & 240 & 186 & 59 \\
\hline COCAINA BASE (grs) & $1.245 .146,50$ & $4.637 .664,94$ & $4.753 .782,44$ & $959.169,00$ & $311.179,70$ & 493,00 & $69.503,00$ & $660.311,50$ & $45.116,00$ \\
\hline CLORHIDRATO DE COCAINA (grs) & $106.768,00$ & $168.235,00$ & $7.628 .896,00$ & $663.250,00$ & $1.061,00$ & 0 & 0 & 4,00 & $34.198,00$ \\
\hline TOTAL COCAINA (grs) & $1.351 .914,50$ & $4.805 .899,94$ & $12.382 .678,44$ & $1.622 .419,00$ & $312.240,70$ & 493,00 & $69.503,00$ & $660.315,50$ & $79.314,00$ \\
\hline MARIHUANA (grs) & $4.518 .371,20$ & $31.993 .655,43$ & $24.134 .047,30$ & $2.147 .481,50$ & $4.159 .604,30$ & $864.484,00$ & $12.130 .464,00$ & $3.636 .661,80$ & $13.276,00$ \\
\hline SS. QQ. SOLIDAS (kgrs) & $46.843,66$ & $241.366,41$ & $266.360,79$ & 515,82 & 855,12 & $2.045,32$ & $11.587,23$ & $9.559,22$ & 0 \\
\hline SS. QQ. LIQUIDAS (L) & $36.332,26$ & $451.907,28$ & $476.537,96$ & $11.302,75$ & $6.219,50$ & $5.010,00$ & $25.111,50$ & $41.097,50$ & 0 \\
\hline HOJA DE COCA (libras) & $426.258,00$ & $219.600,00$ & $114.444,00$ & $32.860,00$ & $1.478,00$ & 0 & $3.595,20$ & 50,00 & 0 \\
\hline LAB. CRISTALIZACION & 0 & 6 & 59 & 0 & 0 & 1 & 0 & 7 & 0 \\
\hline LAB. RECICLAJE & 0 & 6 & 50 & 0 & 0 & 0 & 0 & 6 & 0 \\
\hline FABRICAS DESTRUIDAS & 29 & 2.776 & 1.409 & 6 & 1 & 0 & 1 & 12 & 0 \\
\hline APREHENDIDOS & 523 & 963 & 846 & 241 & 123 & 111 & 162 & 211 & 47 \\
\hline
\end{tabular}

\section{Cuadro Demostrativo por Trimestres Gestión 2015}

\begin{tabular}{|c|c|c|c|c|}
\hline DESCRIPCION & 1er. trimestre & 2do. trimestre & 3er, trimestre & 4to. trimestre \\
\hline OPERATIVOS REALIZADOS & 2.786 & 2.941 & 3.054 & 3.363 \\
\hline COCAINA BASE (grs) & $3.331 .714,43$ & $3.236 .715,30$ & $3.076 .041,50$ & $3.037 .894,85$ \\
\hline CLORHIDRATO DE COCAINA (grs) & $6.561 .497,00$ & $872.435,00$ & $797.964,00$ & $370.516,00$ \\
\hline TOTAL COCAINA (grs) & $9.893 .211,50$ & $4.109 .150,30$ & $3.874 .005,44$ & $3.408 .410,85$ \\
\hline MARIHUANA (grs) & $22.908 .603,60$ & $30.366 .354,32$ & $16.796 .791,91$ & $13.526 .295,70$ \\
\hline SS. QQ. SOLIDAS (kgrs) & $134.153,42$ & $130.442,59$ & $130.085,71$ & $184.451,85$ \\
\hline SS. QQ. LIQUIDAS (L) & $260.907,33$ & $220.331,89$ & $296.401,27$ & $275.878,40$ \\
\hline HOJA DE COCA (libras) & $248.890,00$ & $224.512,00$ & $156.240,00$ & $168.643,00$ \\
\hline LAB. CRISTALIZACION & 20 & 16 & 22 & 15 \\
\hline LAB. RECICLAJE & 20 & 13 & 17 & 12 \\
\hline FABRICAS DESTRUIDAS & 720 & 861 & 1.072 & 1.581 \\
\hline APREHENDIDOS & 941 & 882 & 720 & 684 \\
\hline
\end{tabular}




\section{Bolivia y su relación con la DEA}

Antes de centrarnos en la relación (o no relación) existente entre la DEA y Bolivia, haremos una breve mención sobre que es la DEA:

La misión de la Drug Enforcement Administration (DEA) es hacer cumplir las leyes y reglamentos sobre sustancias controladas de los Estados Unidos y llevar al sistema de justicia penal y civil de los Estados Unidos o cualquier otra jurisdicción competente a aquellas organizaciones y miembros principales de organizaciones, Que participan en el cultivo, la fabricación o la distribución de sustancias controladas que aparezcan en el tráfico ilícito en los Estados Unidos o estén destinados a ese tráfico; Y recomendar y apoyar programas de no ejecución destinados a reducir la disponibilidad de sustancias controladas ilícitas en los mercados nacionales e internacionales.

En el desempeño de su misión como la agencia responsable de hacer cumplir las leyes y regulaciones sobre sustancias controladas de los Estados Unidos, las principales responsabilidades de la DEA incluyen:

Investigación y preparación para el enjuiciamiento de los principales violadores de las leyes de sustancias controladas que operan a nivel interestatal e internacional.

Investigación y preparación para el enjuiciamiento de criminales y bandas de narcotraficantes que perpetran violencia en nuestras comunidades y aterrorizan a los ciudadanos a través del miedo y la intimidación.

$>$ Gestión de un programa nacional de inteligencia de drogas en cooperación con funcionarios federales, estatales, locales y extranjeros para recolectar, analizar y difundir información estratégica y operativa sobre inteligencia de drogas.

$>$ Incautación y confiscación de bienes derivados del tráfico ilícito de drogas, que puedan ser trazados o destinados a ser utilizados para ese tráfico.

> Aplicación de las disposiciones de la Ley de Sustancias Controladas en lo que respecta a la fabricación, distribución y dispensación de sustancias controladas producidas legalmente.

> Coordinación y cooperación con funcionarios federales, estatales y locales encargados de hacer cumplir la ley sobre esfuerzos mutuos de fiscalización de drogas y mejora de tales 
esfuerzos a través de la explotación de potenciales investigaciones interestatales e internacionales más allá de jurisdicciones y recursos federales locales o limitados.

$>$ Coordinación y cooperación con agencias federales, estatales y locales, y con gobiernos extranjeros, en programas diseñados para reducir la disponibilidad de drogas de abuso ilícito en el mercado de los Estados Unidos mediante métodos de no-cumplimiento como la erradicación de cultivos, la sustitución de cultivos y la capacitación de Funcionarios.

$>$ Responsabilidad, bajo la orientación política de la Secretaria de Estado y embajadores de los Estados Unidos, para todos los programas asociados con las contrapartes de la ley de drogas en países extranjeros.

D Enlace con las Naciones Unidas, Interpol y otras organizaciones sobre cuestiones relacionadas con los programas internacionales de fiscalización de drogas ${ }^{67}$.

\section{¿Qué es la DEA y cuál es su trabajo en el mundo? ${ }^{68}$}

Luego de que una investigación periodística involucró al congresista Joaquín Ramírez en un caso de lavado de dinero, te contamos a qué se dedica la DEA.

En un edificio del condado de Arlington, estado de Virginia, se ubica la sede de la Administración para el Control de Drogas (DEA, por sus siglas en inglés), agencia del Departamento de Justicia de los Estados Unidos.

La institución se encarga de luchar contra el contrabando y el consumo de drogas en los Estados Unidos. También es la única responsable de llevar a cabo una política antidroga en el exterior. La DEA cuenta con 227 oficinas de campo y tiene presencia en 62 países. Más de 10800 empleados, de los cuales 5500 son agentes especiales, trabajan para la agencia.

Desde el 13 de mayo del año 2015 el administrador interino de la institución es Chuck Rosenberg, un ex asesor de la Dirección Federal de Investigación (FBI) y fiscal de los Estados Unidos para Virginia. Fundada en el año 1975, por el presidente Richard Nixon, la DEA tiene como misión, según su página web, hacer cumplir "las leyes y reglamentos de los Estados Unidos en materia de sustancias controladas".

\footnotetext{
${ }^{67} \mathrm{https}: / /$ www.dea.gov/about/mission.shtml

${ }^{68} \mathrm{http}: / /$ larepublica.pe/mundo/768004-que-es-la-dea-y-cual-es-su-trabajo-en-el-mundo

Tesis de Maestría
} 
$\mathrm{Su}$ meta es investigar y poner frente al sistema de justicia a las organizaciones que participen en "el cultivo, la fabricación o distribución de sustancias controladas". Su trabajo de investigación para juzgar a los infractores se extiende a otros países, a través de un programa de inteligencia antidroga. En América del Sur tiene presencia en Ecuador, Colombia y Venezuela, principales responsables de la producción de clorhidrato de cocaína en el mundo.

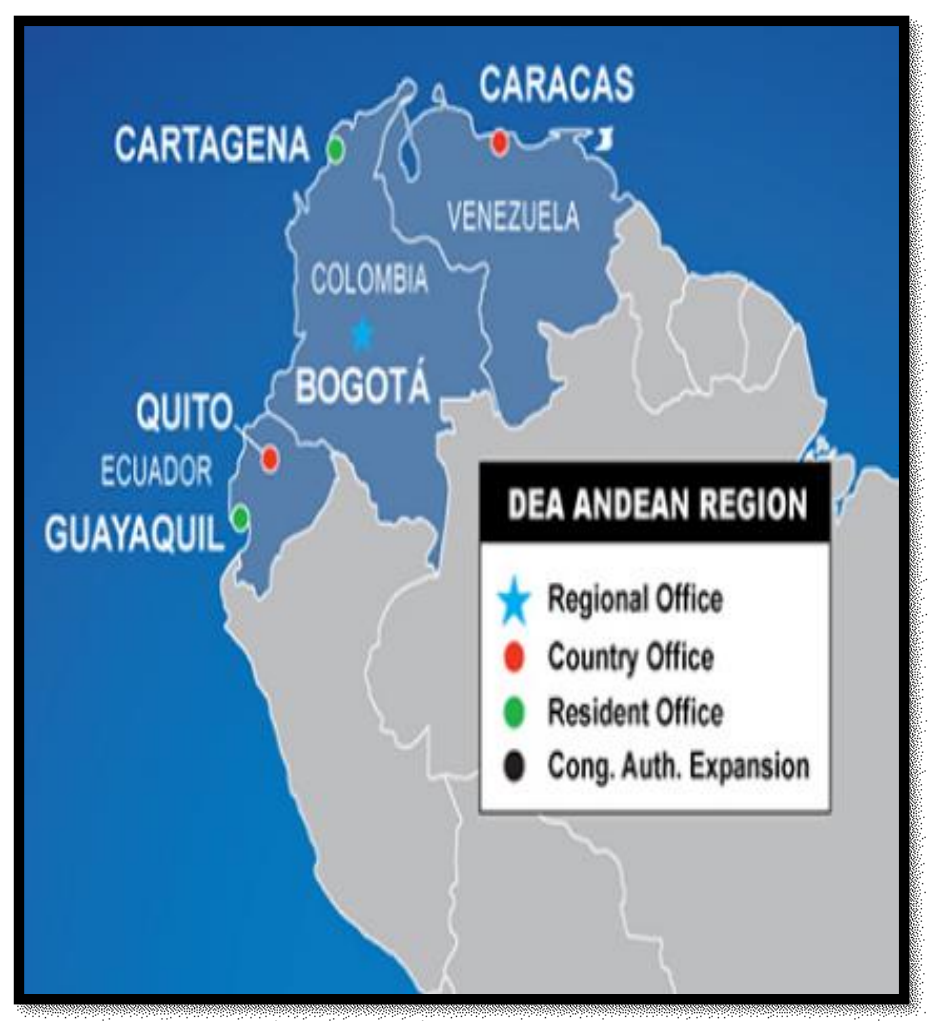

\section{Bolivia rompe con la DEA en la etapa crítica de lucha antidroga ${ }^{69}$}

El 'matrimonio' de más de 30 años entre el Gobierno de Bolivia y la oficina antidrogas de Estados Unidos (DEA), siempre tuvo periodos de gloria y de tormenta, pero esta vez, con el pedido del Presidente de la República para que suspenda operaciones en Bolivia, alcanza la máxima tensión y deja en la incertidumbre la tarea contra el narcotráfico, justo cuando más se necesita unir fuerzas para combatir este flagelo.

En este momento varias razones imponen que Bolivia refuerce la lucha antidroga: su condición de tercer productor de cocaína en el mundo, con más de 104 toneladas (Colombia 600 tn y Perú 290 tn), ubicación que la convierte en zona de tránsito para la cocaína peruana y el haber ingresado en la lista de países productores de marihuana (por lo menos mil toneladas incautadas en lo que va del año). Además, entre 2003 y 2007, el cultivo de coca en Bolivia se incrementó de

\footnotetext{
${ }^{69} \mathrm{http} / / /$ ju.tv/2008/11/bolivia-rompe-con-la-dea-en-la-etapa-crtica-de-lucha-antidroga/ Tesis de Maestría
} 
23.600 a 28.900 hectáreas (según la Oficina contra la Droga y el Delito de las Naciones Unidas, ONUDD).

A pesar del resquebrajamiento de las relaciones Bolivia-EEUU, la incautación de droga en los últimos 10 meses ya superó cifras récord anteriores, según el informe del director de la Fuerza Especial de Lucha Contra el Narcotráfico (Felcn), René Sanabria, quien detalló que en 10 meses de 2008 secuestró 25,5 toneladas de cocaína.

El jefe de Estado negó que con la salida de la DEA los cultivos de coca y la producción de cocaína se incrementen de manera alarmante en Bolivia. Anunció que se incluyó en el Presupuesto General de la Nación una partida para sostener la lucha antidroga con recursos propios y que confía en la labor de la Policía.

No obstante, la primera voz de alerta por la salida de la DEA de Bolivia la dio el ex director nacional de la Felcn, general Luis Caballero, quien advirtió que esta medida dejará a Bolivia aislada, sin coordinación internacional en el combate contra las drogas. Indicó que el alejamiento de la DEA significa un "vacío técnico" en lo referido a la acumulación, manejo, evaluación y análisis de Inteligencia a escala internacional.

El diputado por Podemos, Luis Alberto Pacheco, afirmó que el país quedará huérfano en servicio de Inteligencia, porque el 99\% de las incautaciones de droga se hacía a través de información que la DEA proveía y que eso se lo logra con tecnología y dinero (más de \$us 30 millones anuales que destinaba EEUU).

El Poder Ejecutivo anunció la creación de una unidad de Inteligencia para reemplazar a la DEA, que debe abandonar el país en tres meses, acusada de conspirar contra su gestión. No obstante, el ex viceministro de Defensa Social, Ernesto Justiniano, calcula que este año la producción de cocaína subirá a 125 toneladas y las plantaciones de coca a 31.000 hectáreas.

El Gobierno norteamericano, a través de un comunicado, indicó que la DEA en Bolivia tiene cinco oficinas: una en La Paz, un campamento base en Chimoré y oficinas residentes en Santa Cruz, Cochabamba y Trinidad. Aún tiene trabajando en el país 27 agentes especiales, dos pilotos y cinco analistas de Inteligencia.

La DEA abrió oficinas en La Paz en 1972 y se estableció en Cochabamba en 1986. El lazo que unió más las relaciones entre los gobiernos de Bolivia y de EEUU fue la aprobación de la Ley Tesis de Maestría 
1008 del Régimen de la Coca y Sustancias Controladas, del 19 de julio de 1988, durante el gobierno de Víctor Paz Estenssoro. Con ello empezaron fuertes campañas bajo la promesa de 'coca cero', lucha que se centró en Chapare ante la dura mirada de más de 40.000 familias cocaleras dirigidas por Evo Morales.

En 2006, la DEA ya sabía que con Morales en la presidencia, las cosas podían cambiar. En un informe ante el Congreso estadounidense, el jefe de operaciones, Michael Braun, anunciaba un nuevo reto para las actividades de la DEA. Alertaba que la administración Morales estaba frecuentemente enfrentada al tener que balancear la demanda de los campesinos de despenalizar la coca y mantener las obligaciones de erradicación adquiridas con la comunidad internacional. Kathryn Ledebur, directora de la Red Andina de Información (que analiza el impacto de las políticas antidrogas) aconseja que, con la elección de Barack Obama, redefinir y afinar la cooperación con EEUU en la lucha antidroga, y ve productivos los esfuerzos del Gobierno boliviano de buscar ayuda regional a través de Unasur, la OEA, entre otros.

\section{Entre luces y sombras}

- Bolivia no podía seguir amparando el narcotráfico que reinó en los gobiernos de la dictadura de los 70 y comienzos de los 80 . Las exigencias internacionales hiceron que se abran las puertas a la cooperación externa, principalmente de los EEUU.

- Los resultados fueron tangibles a partir de 1988 con los programas de erradicación de la coca, las incautaciones de cocaína, la aprobación de la Ley 1008 y la extradición de ex autoridades, como Luis Arce Gómez que fue ministro de Gobierno de García Meza.

- La pasada semana, el Poder Ejecutivo dijo que entre otros motivos para expulsar a la DEA del país, está el hecho de la investigación de las cuentas bancarias de Evo Morales y de otros seis masistas el año 2003 por parte de dicha institución.

- El presidente Morales también explicó que la decisión de detener las actividades de la DEA fue tomada por "la dignidad" boliviana, pues la agencia antinarcóticos no respetaba a la Policía ni a los mandos militares. La DEA rechazó las acusaciones. 


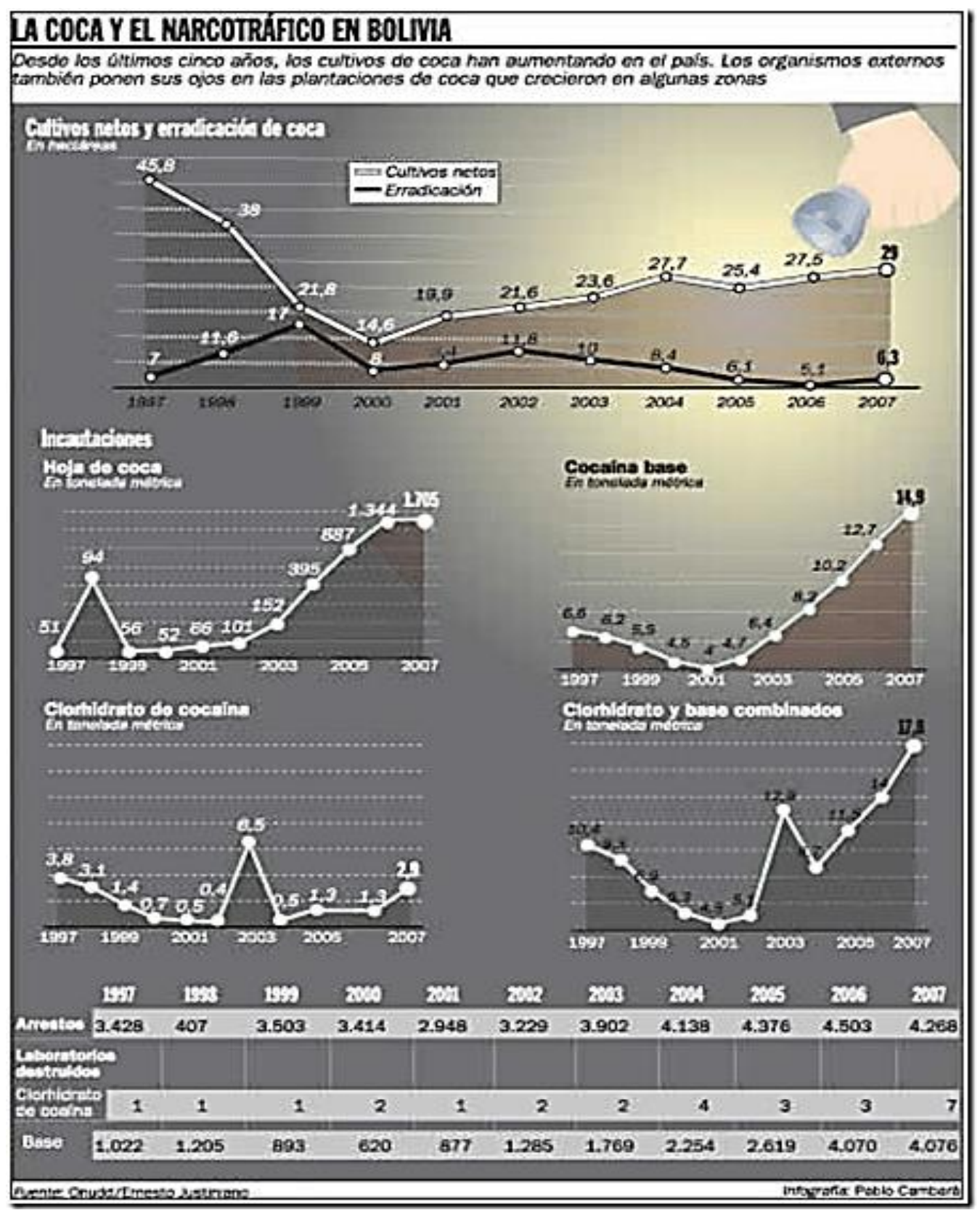

\section{Las fricciones datan desde que Evo era un cocalero}

Narcotráfico. El auge de la droga se dio en tiempos de dictadura. La presión hizo que se aplique muerte civil a los narcos. El asesinato de Noel Kempff marca un antes y un después en la lucha.

La lucha antidroga se centró principalmente en Chapare. La erradicación causó muerte de campesinos y militares. El rechazo de Evo Morales hacia la DEA y otros organismos de apoyo de EEUU empezó mucho antes de convertirse en el inquilino del Palacio Quemado. En la segunda mitad de los 80 , desde su puesto de dirigente máximo de las seis federaciones del trópico de Cochabamba, Evo ya calificaba a la Ley 1008 de draconiana y anticonstitucional porque presume la culpabilidad antes que la inocencia del acusado por delito de narcotráfico. 
Dicha ley fue aprobada por presiones internacionales y nacionales tras el asesinato del científico Noel Kempff, el 5 de septiembre de 1986, en la meseta de Huanchaca, ubicada en la provincia Velasco de Santa Cruz, donde narcotraficantes habían habilitado una pista de aterrizaje clandestina.

La última semana, el presidente Evo Morales acusó a la DEA de dedicarse a fomentar y proteger a grandes narcotraficantes en Bolivia y citó como ejemplo el caso Huanchaca. Dijo que cuenta con documentación sobre las labores de investigación política y seguimiento que realizaron los agentes de la DEA contra los dirigentes y líderes políticos del MAS. "Personalmente he visto, en Villa Tunari, a la DEA disparando contra el movimiento campesino cocalero el 27 de junio de 1988, cuando hubo un problema serio en Eterazama (...) Cinco muertos en un solo día”, dijo el mandatario.

El rechazo a EEUU también lo manifestó en enero de 2000, cuando en medio de un conflicto por el mercado de la coca en Cochabamba, el oficialismo que gobernaba el país expulsó del Parlamento a Evo Morales.

Ernesto Justiniano, ex viceministro de Defensa Social, cree que la actitud de Morales es por el dolor que siente a raíz del descubrimiento que se hizo de que algunos masistas estaban traficando con droga. "En vez de enojarse con sus correligionarios ha preferido pelearse con la DEA", afirmó.

\section{Otras tareas contra las drogas}

- Proyecto. EEUU comenzó a desarrollar operaciones en 1987 con miras a tareas de erradicación e interdicción, a través del Departamento de Estado y su oficina de Asuntos Narcóticos Internacionales. Trabajó inicialmente en 12 países (Guatemala, Panamá, Costa Rica, Argentina, Brasil, Chile, Venezuela, Colombia, Ecuador, Bolivia, Perú y México).

- Clave. La labor dependía de agentes que voluntariamente accedían a cumplir tareas temporales en otros países. Los mismos dejaban sus campos de trabajo para emprender una tarea y trabajar más próximos con un país anfitrión para reforzar la parte legal, normativa.

- Problema. Snowcap, que era un programa temporal, después de siete años de operación, se volvió una parte fundamental de la división de campo de la DEA. La rotación constante de individuos hizo que se introduzcan variaciones en el proyecto original. 
- Resultado. A manera de reorientar el trabajo y como la operación Snowcap ya había alcanzado su objetivo de ayudar a otros países a que sus propias agencias de combate a las drogas sean más autosuficientes, la decisión para la nueva etapa de Snowcap se hizo y las posiciones temporales fueron gradualmente eliminadas.

- Reemplazo. Sin embargo, la DEA optaron por continuar aportando en forma permanente en Perú, Bolivia y Colombia, productores de droga. Estos agentes daban apoyo y asistencia de entrenamiento y servían como consejeros.

\section{El poder y la droga}

Hugo Banzer: 1971-1978 1997-2001

Durante su gobierno se inició el boom del narcotráfico en Bolivia, que siguió durante la década de los años 80. En su segunda gestión, por la vía democrática, se comprometió ante EEUU a luchar contra este flagelo y puso en marcha el Plan Dignidad. Hubo enfrentamientos entre militares y cocaleros.

García Meza: 1980-1981

Un indicio de que su gobierno estuvo financiado por el narcotráfico es que su ministro del Interior, Luis Arce Gómez, fue extraditado a los Estados Unidos durante el gobierno de Jaime Paz Zamora por estar involucrado en narcotráfico. Su gestión también se caracterizó por ser corrupta y autoritaria.

Víctor Paz: 1985-1989

El 19 de julio de 1988, Víctor Paz Estenssoro, en su tercera gestión presidencial, aprobó la Ley 1008 para controlar el régimen de la coca y sustancias controladas. Con ello, el país tenía un marco legal para combatir el narcotráfico y la coca excedentaria, es decir, aquella que no se produce tradicionalmente.

Jaime Paz: 1989-1993

Mantuvo el plan de lucha contra el narcotráfico pero impulsó la campaña 'coca no es cocaína', deportó a EEUU al ex ministro del Interior Luis Arce Gómez, extraditó a Asunta Roca, acusada de narcotráfico, y ejecutó el decreto del arrepentimiento para recluir en cárceles bolivianas a 'peces gordos'.

Sánchez de Lozada: 1993-1997 -2002-2003

Tesis de Maestría 
Manifestó que no era posible hablar de erradicar el 100\% de la coca existente en Chapare con el fin de evitar episodios de sangre registrados con el Plan Dignidad y propuso implementar programas de desarrollo alternativo integral. La base del plan era que no se puede erradicar coca sin erradicar pobreza.

Carlos Mesa: 2003-2005

Tras los hechos de octubre de 2003, el entonces presidente Mesa firmó un convenio con Evo Morales para permitir por un tiempo el cultivo adicional de 3.200 hectáreas de coca en Chapare, donde se considera que los cultivos no son tradicionales. Los analistas lo califican como un cambio en los planes antidroga.

\section{Según policías, será difícil obviar informes de los estadounidenses}

Narcotráfico. La agencia antidroga de EEUU maneja información relevante en la región y el mundo. Los oficiales bolivianos capacitados por ella la califican de irremplazable

La posibilidad de no depender de los informes especializados de la Agencia Antidrogas de EEUU (DEA por sus siglas en inglés) es casi imposible, ya que los datos que manejan son relevantes, pues se trata de la unidad antinarcóticos más grande del mundo.

Así señalaron coincidentemente oficiales y ex oficiales de la Policía boliviana especializados en dicha rama, a quienes se les consultó sobre la factibilidad de operar sin coordinar con dicha unidad. La DEA está presente en todo el subcontinente, a excepción de Venezuela, y ahora Bolivia, tal como lo definió el presidente, Evo Morales.

Pese a ello, los reportes que manejan en el campo de Inteligencia son de tal trascendencia que incluso policías con mayor capacidad operativa y logística que la nuestra, como la de Brasil, están en permanente contacto con sus pares estadounidenses.

Según el ex director de la Felcn Gral. Luis Caballero, uno de los motivos para que el trabajo de la unidad antinarcótivos del país sea tan efectivo es porque se cuenta con el respaldo informativo de la DEA. "Es un organismo con presencia mundial y se relaciona incluso con países que no tienen una línea política con Estados Unidos. Su trabajo es técnico, utiliza a los mejores profesionales en el ramo y tiene un apoyo logístico impresionante", indicó.

Actualmente, la DEA en Bolivia tiene 27 agentes, mucho menos que los 136 que habían hace tres años. La reducción, según fuentes policiales, difiere; unos dicen por la capacitación de las Tesis de Maestría 
fuerzas nacionales ha llegado a tal nivel que no es necesario comandar todos los operativos; otros, señalan que fue a raíz de la asunción de Evo Morales como presidente de la República. "Los norteamericanos ya intuían que no iban a poder trabajar como antes con Morales en el poder, y hablaban de que en cualquier momento iban a dejar de depender de ellos", comentó un alto oficial de la Policía, y que en su momento comandó una de las regionales de la Fuerza Especial de Lucha Contra el Narcotráfico.

La agencia estadounidense tiene una red de agentes e informadores en el mundo que le permite estar al tanto de diversas operaciones de los narcotraficantes. Saben las rutas por donde pasarán los estupefacientes y los lugares de recepción; para ello no escatiman esfuerzo logístico y operativo que les posibilite tener información fidedigna.

Es por ello, dijo una de las fuentes consultadas, que por ejemplo en los últimos 12 meses desbarataron varias redes de narcotraficantes que pretendían transportar cocaína peruana hacia Brasil y países europeos, utilizando a Bolivia como país de tránsito.

"Las ingentes cantidades de droga de Perú que se han incautado es gracias a la información de la DEA”, aseguró un oficial de Umopar para demostrar que esos reportes son esenciales cuando se trata de interceptar un cargamento ilegal que viene de otro país.

Los policías antidrogas bolivianos sólo tienen palabras de elogio para sus similares de EEUU y aseguran que la tarea de coordinación es netamente técnica, resistiéndose a creer que éstos tengan afanes conspirativos, como lo indica el Gobierno

\section{Para resaltar}

- El equipamiento y material técnico de la DEA en Bolivia suman 150 computadoras, decenas de equipos de radiocomunicación, celulares satelitales y equipos electrónicos de espionaje.

- Para las tareas operativas de la Felen tiene 600 motorizados de diverso tipo, 5 aviones Hércules, 18 helicópteros, 36 lanchas del tipo 'piraña' y 'zodiac'.

- En todo el territorio nacional cuenta con inmuebles de 'seguridad' para concentrar sus labores de coordinación y estratégicas antinarcóticos. Todas están debidamente equipadas con tecnología para su trabajo.

- La designación de comandantes de la Policía antidrogas, tanto regionales como el nacional, deben ser aprobados por la DEA. Hasta antes de la gestión de Evo Morales, incluso daban su visto bueno para el nombramiento del ministro de Gobierno. 
- EEUU dona \$us 26 millones anuales para la lucha antidrogas en Bolivia. Ese dinero sirve para costear las necesidades logísticas y operativas de las fuerzas antinarcóticos en el país, y es fiscalizado por la embajada estadounidense.

- Los agentes de la DEA hacen un control riguroso al accionar de los oficiales bolivianos destinados en las unidades antinarcóticos. El más mínimo desliz de los nacionales en sus tareas específicas, supone su relevo inmediato.

- La DEA, a través de la embajada de EEUU, entrega bonos económicos a todos los policías que están destinados en las unidades antidrogas.

- También les dotan de vestimenta y armamento.

\section{Ser policía antidroga es sinónimo de élite y nivel}

La dependencia de los policías antidrogas bolivianos hacia la DEA en cuanto al aspecto operativo y de capacitación es muy notoria.

Según oficiales y policías destinados a las unidades que se encargan del trabajo de interdicción al narcotráfico, pertenecer a una de ellas es sinónimo de ser un uniformado de élite y nivel. "Los que vienen aquí son los mejores y para ello deben cumplir con una serie de requisitos y pasar el 'curso Garras', uno de los de mayor exigencia en el continente", comentó un oficial que está actualmente en Umopar.

Las técnicas que se imparten en dicho curso son las mismas que se dictan a los agentes antidrogas estadounidenses. La capacitación incluye, entre otras, labores de interdicción, monitoreo electrónico, escuchas telefónicas, seguimiento y espionaje.

La evaluación de los graduados es tuición de la oficialidad nacional, pero los de la DEA hacen seguimiento detallado ${ }^{70}$.

\section{Carteles extranjeros de drogas y Bolivia $^{71}$ :}

$\underline{\text { Emisarios de cárteles de droga operan en Bolivia }}$

El ministro de Gobierno dijo que en el país operan enviados de tres importantes organizaciones criminales del narcotráfico de Latinoamérica, pero negó que esos cárteles se hayan instalado en el territorio nacional.

\footnotetext{
${ }^{70} \mathrm{http}: /$ eju.tv/2008/11/bolivia-rompe-con-la-dea-en-la-etapa-crtica-de-lucha-antidroga/

${ }^{71} \mathrm{https}$ ://www.americaeconomia.com/politica-sociedad/sociedad/emisarios-de-carteles-de-droga-operan-en-bolivia Tesis de Maestría
} 
Bolivia se siente acechada por la presencia de emisarios de al menos tres cárteles del narcotráfico de la región y el creciente número de detenciones de extranjeros por narcotráfico en los últimos tres años, principalmente de peruanos, colombianos y brasileños, reconoció el gobierno.

El ministro de Gobierno, Carlos Romero, manifestó que en el país andino operan enviados de tres importantes organizaciones criminales del narcotráfico de Latinoamérica, pero negó que esos cárteles se hayan instalado en el territorio nacional. Manifestó que la droga que se trafica en el país se dirige a Brasil y a países de Europa.

Según su percepción, en el caso norteamericano, por ejemplo, del 100\% de la cocaína que ingresa a ese país se estima que $1 \%$ proviene de Bolivia, de acuerdo con autoridades norteamericanas y en el caso de México, la provisión de droga es de Colombia. Ratificó que no hay carteles instalados en el territorio nacional, pues alcanza sólo a emisarios.

"El admitir que hay carteles significaría que estas organizaciones han penetrado a los organismos del Estado y eso no lo podemos aceptar porque no es así", afirmó. Por su ubicación geográfica, Bolivia es estratégica para llevar a Brasil la droga que viene en su mayoría de Perú.

En agosto, el ministerio de la Presidencia remitió a la Fiscalía documentos de Inteligencia para que indague la presunta actividad de cárteles colombianos y mexicanos, que vincula presuntamente a policías. El 9 de octubre, tras los enfrentamientos entre narcotraficantes y agentes de la Fuerza Especial de la Lucha contra el Crimen (FELCC) en Ichilo amazonia boliviana, el presidente Evo Morales reconoció que San Germán es tierra de "peces gordos del narcotráfico" y ordenó la presencia masiva de la Policía en el lugar.

El problema del narcotráfico en el país se ve alentado principalmente por la exportación del alcaloide hacia países como Brasil por lo que la presencia de emisarios es permanente.A fines de octubre en la ciudad de Santa Cruz (este) a dos "peces gordos" del narcotráfico; uno de nacionalidad boliviana y otro colombiano, cayeron en un operativo de la Fuerza Especial de Lucha Contra el Narcotráfico (Felcn), donde se incautó además armamento de grueso calibre.

Se trata del colombiano, Fabio Adhemar Andrade Limalobo, y el boliviano, Ronald Rivera Roca. Andrade Limalobo es hijo de Célimo Andrade Quintero, uno de los prominentes narcotraficantes que fue capturado en Bolivia el año 1992 y que estuvo a punto de ser rescatado por el Cártel de Cali.

Ronald Rivera Roca ha sido identificado como uno de los principales acopiadores de droga en esa región del departamento de Santa Cruz. Otra evidencia del acecho de carteles en Bolivia, fue Tesis de Maestría 
cuando en noviembre el gobierno boliviano y la Felen confirmó emisarios del Primer Comando de la Capital (PCC), la banda criminal más grande de Brasil, efectuaron operaciones ilícitas en Bolivia. El director de la Felcn, coronel Gonzalo Quezada, informó que las investigaciones determinaron que estas organizaciones criminales usan la ruta nueva hacia Puerto Suárez, el tramo San Ignacio-San Matías y la vía que conecta con Guayaramerín, ubicada en la amazonia boliviana.

En septiembre, la Felcn capturó en Santa Cruz de la Sierra a Ezequiel Dorado, hermano de Ozzie y Maximiliano, son nexos del PCC en Bolivia. Tras la caída de Maximiliano en 2010, los que tomaron la posta para enviar droga al PCC fueron Ezequiel y Ozzie, de acuerdo con las investigaciones de los organismos antidroga. Extranjeros, los emisarios. En Bolivia se ha registrado un creciente número de detenciones de extranjeros por narcotráfico en los últimos tres años, principalmente de peruanos, colombianos y brasileños.

El viceministro de Defensa Social y Sustancias Controladas, Felipe Cáceres, precisó que el hecho tal presencia de extranjeros detenidos por narcotráfico en el país, no implica que los cárteles hayan establecido bases de operación.

Los reportes del Departamento de Inteligencia de la Fuerza Especial de Lucha Contra el Narcotráfico determinaron que la pasta base de cocaína es el tipo de droga que más se pretende sacar del territorio boliviano que proviene del Perú.

Más de la mitad de las sustancias controladas incautadas en 2011 era proveniente de Perú y eso se repite en esta gestión 2012 que son enviadas principalmente a Brasil, porque en ese país están ubicados grandes laboratorios de refinación para obtener clorhidrato, luego siguen los destinos a Europa y muy poca cantidad a Estados Unidos.

De acuerdo con los informes facilitados por el viceministerio de Defensa Social, en el primer semestre de este año se confiscaron más de 21 toneladas de cocaína, cargamento del que dijo el $60 \%$ es droga proveniente del Perú.

La lista de detenidos extranjeros en Bolivia por tráfico de drogas está encabezada por peruanos, colombianos, brasileños y españoles que representa $56 \%$ del total de reos apresados por este ilícito, de acuerdo con el detalle oficial del gobierno. El viceministro Cáceres manifestó que al igual que el año pasado los peruanos, colombianos y brasileños son los más detenidos por el tráfico de drogas, por el circuito que transita la cocaína. Según las investigaciones antidrogas, los Tesis de Maestría 
extranjeros aparentemente controlan la producción de cocaína que se elaboran en las selvas de los departamentos de Santa Cruz, Cochabamba y Beni.

\section{EI sello de los cárteles en la droga boliviana}

Usan desde escudos hasta caricaturas. Los primeros que recurrieron a este método fueron los cárteles colombianos y mexicanos; Es para evitar que les modifiquen los cargamentos, según un jefe antidroga.

Sellos de alto relieve, logotipos con sus respectivos nombres y calcomanías se han convertido en la marca de "garantía" que permite identificar a cárteles de droga que operan en Sudamérica y Europa. En Bolivia este sistema ya es aplicado. Así se ha evidenciado en las últimas intervenciones de agentes antidroga a laboratorios de cristalización de cocaína hallados en Santa Cruz, donde se ha detectado que narcotraficantes colombianos en complicidad con bolivianos marcan su mercancía para su posterior exportación.

Su origen. Según el diario Clarín de Argentina, en la década de los 80 los grandes cárteles colombianos (Cali, Medellín) o mexicanos (Juárez) comenzaron a marcar sus envíos con sellos o logotipos. "De esa manera le garantizaban calidad 'de origen' al comprador y también se aseguraban que los intermediarios no pudieran violar los empaques para rebajar la cocaína", según fuentes de la División Narcotráfico de la Federal.

Hoy el fenómeno de los logotipos narco no sólo continúa sino que se ha ampliado y diversificado: las variedades se cuentan por cientos y ya generaron catálogos policiales a nivel internacional para sus posteriores comparaciones. El registro. La Comunidad Latinoamericana y del Caribe de Inteligencia Policial (CLASIP) integrada por 25 países entre ellas Bolivia ya lleva registrada más de 502 logos narcos.

"Existen organizaciones dedicadas únicamente al transporte de grandes volúmenes de drogas. Como hoy los cárteles son más pequeños, a veces se juntan para hacer un envío con la misma "logística". Los logos sirven para identificar los diferentes cargamentos que viajan en pool", detallaron fuentes de la Dirección Antidrogas de Gendarmería en Argentina.

Su presentación. El jefe de la Fuerza Especial de Lucha Contra el Narcotráfico en Santa Cruz, teniente coronel Fernando Amurrio, indicó que los narcos en Bolivia suelen poner sus marcas para identificar la calidad de su mercadería a traficar. Esta modalidad es una especie de presentación de la misma organización. Según Amurrio, la marcas no vienen de reciente sino desde hace tiempo atrás. 
Otro ex jefe departamental antidroga, que prefiere mantenerse en reserva por temor a represalias, explicó escuetamente que esta modalidad es aplicada por los cárteles colombianos que están por embarcar en el país. "Los sellos sólo lo usan los cárteles de narcos, con esto no quiero decir que ya estén asentados aquí pero sí tienen nexos en el país por lo que se debería investigar porque aparecen más logos narcos en laboratorios", explicó la fuente policial.

La elección. El logotipo o la marca que lleva la droga depende de varios factores. "Algunos se inclinan por sus alias, otros por las siglas de su nombre o el de sus familiares. Los números de tres dígitos y las letras son muy comunes y han sido encontrados en diferentes operativos, afirmó el oficial. En muchos casos, éstas son parte de números de la cédula del narco o fechas importantes para él. En otras ocasiones, son usados símbolos como figuras de animales, calcomanías de dibujos animados o los logos de marcas de vehículos", concluyó la fuente en reserva.

En Bolivia figuras de trébol, león, escorpiones, marca de televisores LG, nombres de personas como Luiz, Totto, Chino, J.V.A., J.N., Chuk, 10J y Sol son cada vez más recurrentes entre los laboratorios de narcotráfico intervenidos.

Calidad. Las mafias "son atraídas por la calidad de la cocaína boliviana”. Dichas mafias cristalizan (purifican) la cocaína y la comercializan en Europa y EEUU, según fuentes oficiales.

La Policía de Investigaciones de Chile (PDI) estableció, según el diario El Mercurio, en sus ediciones pasadas que Bolivia produce pasta base de cocaína con una pureza superior al 95 por ciento. El medio extranjero justificó la publicación basada en un estudio realizado por la Policía de ese país que cárteles colombianos se instalaron ya en Bolivia.

Otros medios impresos fuera del país resaltan que las fronteras bolivianas se han convirtieron en un paso casi obligado para los cárteles u organizaciones de narcos de Colombia, Brasil y México.

20 Países identificó la Casa Blanca como los de mayor producción de droga. Entre ellos Bolivia.

10 Mafias que trafican droga han sido identificadas en todo el mundo. Colombia ocupa el tercer lugar.

Las fronteras están desprotegidas: En el sureste del país, frontera entre Santa Cruz y Paraguay, es donde se han detectado varias fábricas de cristalización de cocaína. 


\section{Datos de la ONU}

INFORME. El organismo de las Naciones Unidas para el control de las drogas manifestó su preocupación por el creciente tráfico de drogas desde México y Centroamérica y la falta de acciones de Bolivia para contener el cultivo de coca.

EL CULTIVO. En el caso de Bolivia, el informe lamentó que no se haya acatado las recomendaciones para reducir el área cultivada con coca, que ha crecido desde 2005.

Precisó que en 2009 el área de cultivo de coca alcanzó 30.900 hectáreas, con un potencial de producción de 40.200 toneladas de hojas de coca.

PRODUCCIÓN. 90\% de la cocaína sudamericana que ingresa a EEUU pasa por México.

Los sellos de droga en Bolivia

1. Mora. Este operativo se concretó en mayo pasado y se detuvo a dos colombianos y dos bolivianos. Un dato que llamó la atención a las autoridades antidrogas fueron los logos encontrados.

2. Okinawa. Se detuvo a cuatro colombianos en un laboratorio de cristalización de cocaína. Se incautaron acetona, diesel, gasolina entre otros químicos. En la zona donde amoldaban la droga se encontró un sello de un trébol.

3. Escorpiones. Este era el sello de garantía del narcotraficante colombianos Henry Loaiza, alias "El alacrán” a quien acusan en Colombia de enviar a matar a más de un centenar de personas ligadas al narcotráfico.

4. San ignacio. En este operativo ejecutado en agosto de 2010 se incautaron 852 kilos de cocaína, envueltos en 772 paquetes que tenían impreso la palabra "Totto", como sello de calidad.

\section{CUESTIONAMIENTOS}

¿Operan los cárteles de narcos en Bolivia?

Los ajustes de cuentas por muertes violentas hacen temer a las autoridades que cárteles de droga de Colombia, Brasil y México estén por desembarcar en el país. Una fuente policial ligada a la información negó que cárteles de narcotraficantes ya estén operando en el país, pero no descartó que ello pueda ocurrir si no se toman medidas urgentes. Sin embargo, más de 50 ejecuciones sin resolver por la Policía desde hace dos años atrás parecen abonar esos temores. 
Debido a que la mayoría de las víctimas recibieron más de cinco impactos de bala en la cabeza y el pecho tras haber sido secuestrados, cómo el último caso sin resolver donde un hombre apareció enmanillado con disparos en la cabeza botado en una senda pasando la localidad de Montero Hoyos.

El viceministro Felipe Cáceres argumenta que "cuando se habla de un cártel, significa que tienen una estructura armada, tipo militar, por tanto se supone que ésta tiene nexos más bajos, con gente inmiscuida en el crimen organizado y que desconoce a los líderes: a eso se le llama cárteles. Lo que en Bolivia hay son clanes familiares".

Según medios internacionales en Bolivia ya se encuentran asentadas miembros del cártel Norte del Valle de argentino y del Comando Vermelho de Brasil ${ }^{72}$.

Narcos de 8 países tienen operaciones en Bolivia: Grupos de 8 países operan en la producción y comercio de droga

En Bolivia operan grupos de narcotraficantes de ocho nacionalidades que alientan la producción y comercio de droga a tal punto que la ilícita actividad está saliéndose de control, entre otros factores por la presencia de más coca y la falta de desmantelamiento de estos grupos.

La información la proporcionaron jefes de la Fuerza Especial de Lucha Contra el Narcotráfico (FELCN), que coinciden en que el secuestro del narcotraficante William Rosales y la ejecución de seis de sus guardaespaldas en San Ramón, el 14 de mayo, es muestra de la tendencia creciente de la problemática del narcotráfico.

En este caso están vinculados colombianos y brasileños, según el capitán Orlando Araujo, uno de los acusados de la matanza de mayo. Tres serbios cayeron en ese hecho que, según se informó a La Razón, se desató por el asesinato de dos nigerianos ligados a narcos paraguayos. Una de las fuentes de la fuerza antidroga dijo que no sólo operan grupos de esas nacionalidades, sino también peruanos, libaneses, mexicanos y hasta españoles.

Financiamiento. "Estos grupos operan con enlaces en el exterior. Los narcos colombianos son los que tienen mayor presencia y poder; los brasileños los secundan. Luego están, en menor medida, el resto de organizaciones", explicó otra de las fuentes de la FELCN. En octubre del 2009, el entonces jefe antidroga y hoy comandante de la Policía, Óscar Nina, reveló que carteles mexicanos invertían en Bolivia vía mafias colombianas.

\footnotetext{
${ }^{72} \mathrm{https}: / /$ www.eldia.com.bo/index.php?cat=362\&pla=3\&id_articulo=64151 Tesis de Maestría
} 
El viceministro de Defensa Social, Felipe Cáceres, confirmó que las organizaciones delictivas del Brasil, el Primer Comando Capital (PCC) y el comando Vermelho, tienen nexos con narcotraficantes bolivianos. Hasta mayo se capturó a más de 1.478 narcotraficantes y se incautó un total de 14 toneladas de cocaína. "La lucha contra las drogas no sólo es la incautación. Lo principal en esta guerra es la desarticulación de organizaciones delictivas y hasta ahora sólo se desarticuló una, con la detención de 14 colombianos, entre ellos un pez gordo", explicó la fuente.

Este factor, sumado a la presencia de extranjeros en el narcotráfico, extensión de cultivos de hoja de coca, anulación de los informantes por falta de presupuesto y la incorporación de policías, sin haber pasado por el curso "Garras del Valor", a la FELCN, son señales de la pérdida del control de la ilícita actividad, coincidieron las fuentes antidroga consultadas. "Los informantes son determinantes. En el pasado (cuando estaba la estadounidense DEA) se pagaba hasta 50 mil dólares por información", recordó una de las fuentes, quien explicó que "hoy se descubre laboratorios de droga porque se intensificó el narcotráfico". Entre las reacciones en países vecinos está la del Gobierno de Chile, que informó que planea construir un "cerco electrónico" en su frontera con Bolivia y Perú para evitar el tráfico de droga. El candidato presidencial del Brasil, José Serra, dijo que de un 80 a un 90 por ciento de la cocaína que llega a Brasil procede de Bolivia y que el gobierno de Morales tiene que ser "cómplice" o culpable por omisión.

Nina informó el jueves que grupos de narcotraficantes extranjeros visitaron Santa Cruz para hacer contactos. "Vamos a tomar previsiones para evitar que nuestro país se colombianice o suceda lo que está pasando en Brasil o México", sostuvo.

\section{Datos de droga incautada}

De enero al 17 de mayo del 2010 se decomisaron 884,81 toneladas de droga, según el Viceministerio de Defensa Social. Del total, 12,57 toneladas son de pasta base de cocaína, 1,15 toneladas de clorhidrato y 871,09 de marihuana. Los datos agregan que la cantidad de cocaína secuestrada durante la gestión de Evo Morales es mayor a las de años anteriores. Del 2000 al 2005 se secuestraron 48,40 toneladas frente a las 101,42 decomisadas del 2006 al 17 de mayo de este año. En este tiempo se incautaron 4.470,23 toneladas de marihuana

Fiscalía de Cádiz habla de nexos con Bolivia. Un operativo desarticuló una red que llevaba droga de Bolivia a España. Bandas internacionales que operan en España tienen vinculaciones en Bolivia e internan cocaína al país europeo, informa el periódico español La Voz Digital, citando a la Fiscalía de Cádiz. 
Una nota del periódico informa que el tráfico internacional de cocaína está creciendo y que la memoria de la Fiscalía de Cádiz hace énfasis en el asentamiento de bandas, de carácter internacional, que importan la cocaína directamente desde los países productores, sin recurrir a los representantes de los carteles que están afincados en Madrid. Una de las investigaciones desarrolladas el año pasado y que le mostró a los cuerpos y fuerzas de seguridad del Estado esta evolución del narcotráfico que se padece en el ámbito local, fue el "caso Santa Cruz".

El grupo para los estupefacientes de la Policía Nacional de Jerez desmanteló una organización que enviaba a "correos" desde Cádiz a Bolivia para hacerse con partidas de cocaína que directamente se introducían en Jerez, principal centro de distribución de esta sustancia en la provincia. En julio de ese año se dieron por concluidas unas pesquisas que permitieron bloquear la salida de cuatro "muleros" gaditanos (de Cádiz) que pretendían llegar a España con kilos de cocaína que presumiblemente iban a ser vendidos en la provincia ${ }^{73}$.

Dos de los arrestados cayeron en días distintos en el aeropuerto de Guarulhos (Sao Paulo, Brasil), otro en Amsterdam y un cuarto en el aeródromo de Corumba-Mato Grosso del Sur (Brasil). De esta forma, agrega La Voz Digital, la provincia española no es sólo lugar de paso de cargamentos introducidos por la costa y con destino final a Europa; sino que está recibiendo cocaína para su distribución por las localidades de Cádiz y otras zonas.

La estrategia de los traficantes de droga es "un salto cualitativo", como subraya la Fiscalía de Cádiz, que se produce por el auge en la demanda de esta sustancia entre los consumidores. Los narcos ven así en esta zona un mercado propio por explorar.

Director de la FELCN dice que sólo hay clanes familiares, no bandas: Félix Molina asegura que todo está bajo control y que en Bolivia no hay carteles

El director nacional de la Fuerza Especial de Lucha Contra el Narcotráfico (FELCN), coronel Félix Molina, negó que dentro del país operen organizaciones internacionales de narcotraficantes y más bien aseguró que los grupos detectados pertenecen a clanes familiares. Aseguró que la situación del narcotráfico en el país sigue bajo control.

Agregó que es imposible que operen carteles internacionales, porque éstos "someten a una comunidad o un espacio físico, obligan a los vivientes del lugar a pensar como ellos. Obligan a defenderlos y es más, les dan dinero y armas y hacen frente a las fuerzas regulares del Gobierno. Eso no hay en nuestro país". "Por lo menos hasta hoy día, y de acuerdo al reporte de Inteligencia,

\footnotetext{
${ }^{73} \mathrm{http} / /$ eju.tv/2010/06/narcos-de-8-pases-tienen-operaciones-en-bolivia/ Tesis de Maestría
} 
podemos decir que no hay carteles internacionales en Bolivia, más bien hay clanes familiares que es probable que dependan de una organización extranjera, porque la cocaína pasa por Bolivia, la mejoran y luego sale al exterior", aseguró la autoridad policial.

Los clanes familiares están conformados, en su mayoría, por bolivianos, colombianos, peruanos y ciudadanos ecuatorianos, explicó Molina. Molina agregó que en los operativos realizados este año por la Policía antinarcóticos se arrestó a 15 colombianos que pertenecían a clanes familiares y a otros 62 que realizaban actividades de narcotráfico en Bolivia. "Suponemos que a los 62 colombianos los llevaron a la cárcel de Palmasola (Santa Cruz), pero la justicia en Bolivia trabaja de mala manera y tal parece que los liberan casi de inmediato y se vuelven a su país o se quedan”, agregó.

RESULTADOS. Molina destacó que gracias a las tareas de la FELCN se combate efectivamente la actividad ilícita en el país. Por esto es que rechazó la posibilidad de que las cosas se salieran de control

Agregó que todos los efectivos antinarcóticos han sido capacitados en el curso Garras de Valor, con lo cual contradijo los informes dados a La Razón por otras dos fuentes de esta institución policial que indicaron que se estaban incorporando policías que no los cursaron.

Reconoció que se han logrado "resultados históricos" en el último tiempo. "Por ejemplo en lo que va de este año se secuestraron casi 15 toneladas de cocaína”. También se ejecutaron 6.387 operativos. El año pasado, según informes del Viceministerio de Defensa Social, se realizaron 11.366 de estas acciones y en 2008, 10.795. El coronel Molina agregó que de enero a junio de este año se secuestró un total de 665.808 kilos de sustancias sólidas y 1.196.086 litros en productos líquidos que se utilizan para la elaboración de la pasta base de cocaína.

"Estamos hablando también que en lo que va del año se han destruido 13 laboratorios de cristalización de los cuales diez tenían también lo que se conoce como material de reciclaje; esto significa que estas sustancias para cristalizar son utilizadas más de una vez”, informó Molina. Además, se logró destruir en total 2.646 fábricas que tenían 3.766 pozas para la maceración de la coca. Los operativos realizados por la Fuerza Especial de Lucha Contra el Narcotráfico han permitido además detener a 1.744 personas, de las cuales la mayoría es boliviana, informó el coronel Molina.

\section{El comando vermelho en Bolivia: Desde Brasil}


El brasileño José Paulo Vieira de Mello, vinculado al grupo delictivo comando Vermelho y uno de los principales allegados del líder del grupo Fernandinho Beira-Mar, fue detenido en Uruguay y dijo que estuvo en Bolivia. La banda es una de las principales de Brasil. Su central está en Río de Janeiro y se vincula al tráfico de armas y droga ${ }^{74}$.

\footnotetext{
${ }^{74}$ http://eju.tv/2010/06/narcos-de-8-pases-tienen-operaciones-en-bolivia/ Tesis de Maestría
} 


\section{CAPITULO IV:}

\section{El Narcotráfico en la Argentina}

El narcotráfico es el tema más resonante en la agenda de la Seguridad Ciudadana argentina del último año. El mismo se erige como la actividad más lucrativa a nivel mundial. En América Latina se concentra la producción de gran parte de las drogas, en especial la cocaína, y en Estados Unidos se concentra la demanda, al ser el país con los valores más altos de consumo. La Organización Panamericana de la Salud calcula un movimiento de 600.000 millones de dólares; para fuentes norteamericanas se ubica en 400.000 millones anuales. Bobea (2008), por su parte, estima que el dinero del tráfico de drogas representa el 3,1\% del PBI regional, para tomar sólo dos casos nacionales.

A continuación se presenta el marco normativo que rige al narcotráfico en Argentina, para luego analizar algunos factores que pueden fomentar su desarrollo $\mathrm{y}$, posteriormente, realizar un diagnóstico de la situación.

\section{Marco Normativo}

La Argentina ha ratificado los principales tratados e instrumentos internacionales vinculados al control de los estupefacientes. Deben destacarse la Convención Única sobre Estupefacientes, de 1961, enmendada por el Protocolo de 1972, cuyo objetivo es limitar exclusivamente a usos médicos y científicos el cultivo, la producción, la fabricación, la comercialización, la distribución, la posesión y el empleo de estupefacientes. Por otra parte, en 1971 se aprobó el Convenio sobre Sustancias Psicotrópicas, que establece un sistema de fiscalización internacional de dichas sustancias e introduce controles sobre productos farmacéuticos y otras sustancias psicotrópicas sintéticas, a fin de limitar su empleo a usos científicos y/o medicinales.

Más tarde, en 1988, se aprobó la Convención de las Naciones Unidas contra el Tráfico Ilícito de Estupefacientes y Sustancias Psicotrópicas, que plantea la necesidad de implementar medidas de control respecto de precursores, productos químicos y disolventes, que se usan normalmente en la fabricación de estupefacientes.

En lo relativo al marco estrictamente nacional, la norma más relevante es la Ley $\mathrm{N}^{\circ} 23.737$, de 1989. El artículo 5 de la Ley castiga con pena de reclusión o prisión de cuatro a quince años y multa al que sin autorización o con destino ilegítimo: a) Siembre o cultive plantas o guarde semillas utilizables para producir estupefacientes, o materias primas, o elementos destinados a su Tesis de Maestría 
producción o fabricación; b) Produzca, fabrique, extraiga o prepare estupefacientes; y c) Comercie con estupefacientes o materias primas para su producción o fabricación o los tenga con fines de comercialización, o los distribuya, o dé en pago, o almacene o transporte.

También impone de cuatro a quince años y multa al que introduzca al país estupefacientes fabricados o en cualquier etapa de su fabricación o materias primas destinadas a su fabricación o producción, habiendo efectuado una presentación correcta ante la Aduana y posteriormente alterara ilegítimamente su destino o uso. Además estipula una pena de reclusión o prisión de ocho a veinte años y multa al que organice o financie cualquiera de estas actividades ilícitas. La norma posee un enfoque eminentemente represivo, penando no sólo la tenencia (uno a seis años), sino también la tenencia para uso personal (un mes a dos años). Debe puntualizarse que la jurisprudencia de la Corte Suprema, en el caso Arriola, ha declarado la inconstitucionalidad de la punibilidad de la tenencia de estupefacientes para consumo personal, aunque aclarando que las circunstancias deben analizarse en cada caso concreto -asimismo, debe tenerse en cuenta el alcance a las partes de las sentencias judiciales, incluso cuando declaran la inconstitucionalidad de normas

Más recientemente, en 2005, se dictó la Ley 26.045, que creó el Registro Nacional de Precursores Químicos (RENPRE), que funciona en el ámbito de la Secretaría de Programación para la Prevención de la Drogadicción y la Lucha contra el Narcotráfico (SEDRONAR). El Registro debe efectuar el control de la tenencia, utilización, producción, fabricación, extracción, preparación, transporte, almacenamiento, comercialización, exportación, importación, distribución o cualquier tipo de transacción con sustancias o productos químicos autorizados y que por sus características o componentes puedan servir de base o ser utilizados en la elaboración de estupefacientes. La sanción de la Ley constituye un gran avance, puesto que Argentina posee una industria química desarrollada y su falta de control es sin duda una fuente de cultivo para el narcotráfico Pero más allá de la estructura jurídica, resulta importante señalar cuáles son las instituciones que se abocan a controlar y combatir el narcotráfico. En el Poder Ejecutivo, mientras hasta el año 2013 la totalidad de las funciones le competían a la SEDRONAR, en virtud del reciente dictado del Decreto $N^{\circ} 48 / 2014$ se realizó una escisión en los términos siguientes:

La SEDRONAR tiene la función de elaborar políticas y planificar estrategias nacionales para la prevención y capacitación sobre el uso indebido de estupefacientes, brindar asistencia técnica para la capacitación en la materia del personal de las Fuerzas, centralizar la recopilación de datos y coordinar las actividades de investigación, además 
de presidir el Consejo Federal para la Prevención y Asistencia de las Adicciones y Control del Narcotráfico.

$>$ Por otra parte, en el ámbito de la Secretaría de Seguridad del Ministerio de Seguridad, se creó la Subsecretaría de Lucha contra el Narcotráfico, que se debe encargar del desarrollo de políticas nacionales y de la planificación de estrategias contra la producción, el tráfico y la comercialización de estupefacientes. Por su lado, el Poder Legislativo cuenta con una Comisión específica dentro de la Cámara de Diputados, para la "Prevención de Adicciones y Control del Narcotráfico", sin perjuicio de la existencia de las Comisiones de Seguridad Interior propias de cada Cámara.

El Poder Judicial será tratamiento de un capítulo aparte, y en lo referido al llamado "cuarto poder", el Ministerio Público, cabe adelantar la existencia de la PROCUNAR o Procuraduría de la Narcocriminalidad, creada el 19 de febrero de 2013. Se encarga de apoyar la tarea de los fiscales en las investigaciones y juicios sobre narcocrimen, reunir información para diseñar políticas de persecución penal e intervenir en los procesos cuando fuese oportuno ${ }^{75}$.

Con antelación a proceder a presentar algunos datos sobre el narcotráfico en Argentina, la siguiente sección estipula algunos factores que inciden en el desarrollo del mismo.

\section{Algunos Factores que permiten el avance del narcotráfico en Argentina}

Como todo fenómeno complejo el narcotráfico se distingue por su multicausalidad. Los factores a mencionar pueden agruparse en tres tipos: a) estructurales, relacionados con la economía y los procesos sociales de mediano plazo; b) geopolíticos, asociados al desplazamiento y la expansión de redes criminales de otros países y a la geografía del narcotráfico en sí y c) políticoinstitucionales, referidos a los aspectos normativos internos de Argentina.

\section{Factores Estructurales}

Por supuesto que el narcotráfico no es nuevo en Argentina, empero, sí parece manifiesto un crecimiento en las últimas décadas de las actividades relacionadas a su desarrollo, así como tendencias antes inexistentes. En términos teóricos simplificados, puede afirmarse que cualquier organización criminal de envergadura dedicada al narcotráfico requiere al menos dos tipos distintos de actores. Por un lado, los líderes o quienes organizan al grupo, que obtienen la mayor parte de las ganancias y que incluso pueden ser en muchas ocasiones delincuentes de cuello blanco, ocasionalmente puede haber también apoyo por parte de personas que no son parte

\footnotetext{
${ }^{75}$ Resolución N²08/2013 de la Procuraduría General de la Nación Tesis de Maestría
} 
íntegra del grupo, pero colaboran en algunos procesos, como el blanqueo de dinero. Por otro lado, está la mano de obra, sujetos que se encuentran más expuestos, que en muchos casos realizan las tareas de mayor riesgo y menores ganancias y que, usualmente, son reclutados entre los sectores más jóvenes y vulnerables. Este sector ha crecido considerablemente en las últimas décadas y es meritorio estipular algunos posibles lineamientos de por qué esto ha sido así.

Durante la totalidad del siglo XX, el gobierno argentino mantuvo una postura represiva para con los grupos criminales y en especial para con el narcotráfico. Esta perspectiva se solidificó durante la última dictadura militar que privilegió el control social y criminal por sobre la salud pública, la prevención y el bienestar.

Durante los 90, se llevaron a cabo, junto con una descentralización administrativa, medidas de corte neoliberal, que incluyeron privatizaciones, flexibilización laboral, $y$ un rol predominantemente pasivo por parte del Estado. Como resultado, hacia el final de la década se percibía un fuerte incremento de la pobreza y la desigualdad, hecho que junto a otras circunstancias derivó en la crisis del 2001.

Si bien en el nuevo siglo la economía creció fuertemente, y se tomaron medidas mucho más intervencionistas, el impacto del crecimiento no fue igual para todos. En particular, los más afectados parecen ser los más jóvenes, pues según la Encuesta Permanente de Hogares de 2010, aproximadamente un $24 \%$ de la población de entre 18 y 24 años no estudia ni trabaja y de ellos un $71 \%$ no busca trabajo. El desempleo juvenil es casi el cuádruple del desempleo en adultos (18,5\% frente a un 5,1\%). Además, una gran parte de quiénes sí trabajan lo hacen en la informalidad. Por otra parte, y de manera previsible, el problema es mucho más serio en los sectores más pobres. Un $51 \%$ de los jóvenes que no estudian ni trabajan provienen del quintil más bajo de la distribución de ingresos, y si se contempla también al quintil siguiente, el guarismo es de un 77\%. También se ha detallado que en Argentina el 54\% de los arrestados en 2009 por delitos vinculados al tráfico de drogas con estatus de empleo conocido, se hallaban desempleados (UNODC, 2012).

En las últimas décadas, según plantea Föhrig, se han roto tres agencias de socialización fundamentales. Por un lado, el trabajo, pues en la década del '70 más del 90\% de los trabajadores argentinos se hallaban registrados, lo que otorgaba un horizonte de estabilidad y la capacidad de articular un proyecto de vida en un mundo de certidumbre. Esta situación se deshizo en el último cuarto de siglo y con especial énfasis en los 90, y más allá del avance en la última década, aún más de un tercio del trabajo es informal. En segundo lugar, la agencia de socialización que es la 
escuela también se deterioró, no sólo por la ya mencionada presencia de una gran número de jóvenes que no concurren a las instituciones educativas, sino también porque las mismas han mutado su función, y muchas veces actúan como ámbitos de socialización primaria más que secundaria, en donde los niños se alimentan antes que educarse. En tercer lugar, la familia se ha modificado de manera significativa, porque entre los grupos más vulnerables hay una fuerte presencia de familias monoparentales.

Todo esto origina una fuerte presencia de jóvenes que ya llevan varias generaciones sin pasar por las instituciones de socialización típicas y para quienes la principal institución socializadora se halla completamente desmembrada. Todo este conglomerado de jóvenes es más vulnerable a ser reclutado por las organizaciones criminales porque constituyen una enorme fuente de mano de obra barata. Si bien es cierto que les son útiles en particular a las organizaciones de narcotraficantes, para desarrollar las actividades más riesgosas, no debe dejar de recordarse que la interconexión entre el narcotráfico y otros delitos complejos es altísima. Por ende, esta gran masa de jóvenes son víctimas y colaboradores de manera simultánea de las organizaciones criminales. Para ellos, las mismas representan quizá la salida más directa hacia una fuente de ingresos, mientras el mercado laboral formal los excluye.

- Tal vez el mejor reflejo de esta situación lo constituye un sucinto estudio realizado por el Colectivo de Acompañantes Juveniles del Instituto de Recuperación de Adolescentes de Rosario (2012), una ciudad particularmente afectada por la violencia entre bandas, que entrevistó a cuarenta y ocho jóvenes de entre 16 y 18 años que se encontraban a principios de 2012 en el Instituto, por causas que van desde robos a homicidios. Entre los resultados más destacados, se hallan los siguientes:

Respecto de las zonas de residencia, el 94\% proviene de barrios periféricos.

- En cuanto a la escolarización, el 83\% no terminó la escuela primaria y ninguno la secundaria, concordando esto con el deterioro de la función de la escuela.

- En lo referente a los lazos familiares, sólo el 23\% vive con ambos padres. Otro 23\% no vive con ninguno de los padres y el $44 \%$ vive solamente con la madre. Además, el $21 \%$ tiene alguno de los dos padres fallecido y el 19\% tiene alguno de los padres preso.

- Asimismo, el promedio de hermanos es de 5,8 (incluyendo los hermanastros, dado que el $65 \%$ tiene medios hermanos). El 23\% tiene al menos un hermano muerto por violencia o sobredosis y el 31\% tiene algún hermano en prisión. El 40\% tiene hijos, aunque sólo la mitad convive con ellos. 
- El consumo de drogas comienza generalmente a los doce o trece años. Todos consumen sustancias psicoactivas. El 65\% consume cuatro sustancias o más, siendo el tabaco, la marihuana, la cocaína y los psicofármacos las más consumidas. La frecuencia es predominantemente diaria.

Son además múltiples las muestras de que suelen ser los jóvenes y los niños quienes son empleados en los denominados "búnkeres"15, pequeños puntos de expendio ilegal en pocas cantidades de droga que suelen hallarse en medio de los barrios carenciados. Estos jóvenes son denominados "soldaditos" y pueden estar horas en una casilla intercambiando a través de una pequeña ranura dinero por drogas. De acuerdo con un estudio de Eventon (2013), a un "soldadito" se le paga aproximadamente $\$ 150$ por atender un bunker durante todo un día, mientras que el valor es de $\$ 400$ si se trata de un mayor de edad. En el mismo sentido, los "soldados" que se hallan fuera de los búnkeres con funciones de custodia cobran entre $\$ 150$ y \$300, dependiendo de si están armados. Finalmente, \$1500 parece ser el valor que ronda la protección policial.

\section{Factores Geopolíticos}

Además de estos factores de índole social, existe toda otra serie de factores de carácter geopolítico e histórico que favorecen el avance del narcotráfico en Argentina. Por empezar, el aumento del consumo abrió una nueva fuente de demanda para las organizaciones de otros países, especialmente colombianas, con tasas de retorno más rápidas a la inversión. Este autor sostiene que la llegada de las Bacrim a países como Bolivia, Perú, Argentina, España o Brasil, se enmarca en el denominado trasplante criminal. Pero para realizar este trasplante las bandas no contaron con una base de compatriotas afianzada en los países mencionados; por ende, mientras que las Bacrim han sido organizaciones mafiosas en Colombia, el trasplante a estos nuevos países fue sólo en su dimensión criminal, centrándose en tres líneas: tráfico y alianzas para la comercialización al por menor de cocaína; lavado de activos y refugio de cabecillas, que suelen instalarse como prósperos empresarios. El tráfico hacia Europa desde países como Argentina y Brasil comenzó a implicar menores riesgos de incautación que el tráfico desde Colombia. Rico afirma que el trasplante de las Bacrim a países como Argentina se dirigió hacia los centros urbanos más poblados. Esta expansión de las bandas hacia países del cono sur trajo aparejado un aumento del consumo en esas zonas: incluso cuando podía considerarse a Argentina como un país únicamente de tránsito, muchos de los pagos comenzaron a hacerse directamente con droga y eso tendió a aumentar el consumo-. Con el crecimiento de las bandas, las mismas comienzan a cooptar a ciertos estratos del poder por un lado, y a ganar lentamente legitimidad por el otro, 
sobre todo en los barrios más pobres, donde al Estado le cuesta más llegar, a pesar de los avances que se han dado luego de la crisis de 2001. Otro de los motivos que incentiva a los criminales a situarse en las villas y barrios precarios, es un factor meramente situacional, pues la geografía de las mismas hace que la llegada de las Fuerzas del orden sea más dificultosa.

Por otro lado, el descenso en el flujo de cocaína desde Venezuela hacia África fue compensado por el traspaso de droga desde Brasil y Argentina. Todo ello es parte de una nueva geografía del narcotráfico, en donde ha aumentado la demanda por parte de países europeos y africanos, y ha disminuido la demanda de cocaína por parte de Estados Unidos -que de todos modos sigue siendo el primer consumidor mundial- trasladándose la misma hacia las drogas sintéticas (Garzón Vergara, 2013). La situación de Argentina como país portuario no ayuda en este sentido.

Pero además, hoy en día Perú se ha constituido como el primer productor mundial de hoja de coca y en ese país también se desarrolla la producción de pasta base. En ese contexto, Argentina ingresa como una zona en la que puede completarse el circuito de producción que se inicia en Perú, en parte debido al desarrollo de su industria química.

\section{Factores Institucionales}

Son múltiples los factores institucionales que pueden resultar incentivos para el crimen organizado, y con estos factores en particular resulta más correcto el concepto de incentivos que el de causas o determinantes. Aquí, vale la pena destacar dos de ellos:

- El escaso control en las fronteras, tanto en el espacio aéreo como en el terrestre y el marítimo. Esta situación colaboró primero en la consolidación de Argentina como país de tránsito y parece fomentar en la actualidad el desarrollo de su etapa productiva. Si bien son meritorios los objetivos que el llamado "Operativo Escudo Norte"17 se plantea aumentar la vigilancia y el control del espacio terrestre, fluvial y aéreo en las fronteras noreste y noroeste del país, así como detener y poner a disposición de las autoridades judiciales a los potenciales criminales- el mismo aún no ha mostrado sus resultados. Recientemente, el Ministerio de Seguridad de la Nación informó la existencia de al menos mil cuatrocientas pistas de aterrizaje clandestinas. En 2004, por medio del Decreto $\mathrm{N}^{\circ} 1.407$ se creó el Sistema Nacional de Vigilancia y Control Aeroespacial (SINVICA), con el objetivo de controlar el espacio aéreo y desarrollar radares de industria nacional, a través de la empresa INVAP. No obstante, la implementación de los radares aun es limitada y el ingreso de estupefacientes por vía aérea se ha vuelto más frecuente. 
- El escaso control de la industria química. Argentina es uno de los países de Latinoamérica que posee una industria química con alto desarrollo, y muchos de los precursores químicos que son empleados en el procesamiento de estupefacientes se encuentran disponibles, para fines lícitos, en el país. Estos precursores requieren de un mayor control que imposibilite su uso para fines ilegales. Un avance ha habido con la sanción de la Ley $\mathrm{N}^{\circ} 26.045$ en 2005 porque al crearse el Registro Nacional de precursores químicos se le impuso un mayor control a la industria. La sanción fue recientemente destacada por la Junta Internacional de Fiscalización de Estupefacientes (JIFE, 2014). No obstante, los escasos recursos y la escasa cantidad de personal del RENPRE dificultan su accionar, que en gran parte se limita a la generación de una lista de compañías dedicadas a la producción y comercialización de precursores químicos, y a la estipulación de cantidades permitidas de sustancias que cada compañía puede manipular.

\section{Diagnóstico}

Los datos referidos al crimen organizado siempre deben leerse con cautela, porque su certeza siempre es relativa, tratándose justamente de una actividad ilícita.

Hecha esa aclaración, se presentan a continuación algunos datos extraídos de la base de UNODC referidos a las incautaciones de distintas drogas en Argentina. El Gráfico I muestra la cantidad de kilogramos de cannabis incautados en Argentina, llegando la serie hasta 2009. Desde 2005, puede observarse un paulatino aumento, con una leve caída en 2009, siendo el pico en el año 2008 con 107.530 kilogramos. Aquí debe aclararse que el aumento en las incautaciones puede deberse a dos factores: un incremento en la comercialización o uso de las drogas; o un incremento en el esfuerzo operacional o en la eficiencia de las Fuerzas policiales en su labor. Si bien suele afirmarse que las incautaciones rondan el 10\% del circulante total, no existen datos fidedignos al respecto. 
A nivel regional, en 2009 el país que mayor cantidad incautó fue Colombia, con 208.875 kgs

\section{Incautaciones de Marihuana en kilogramos}

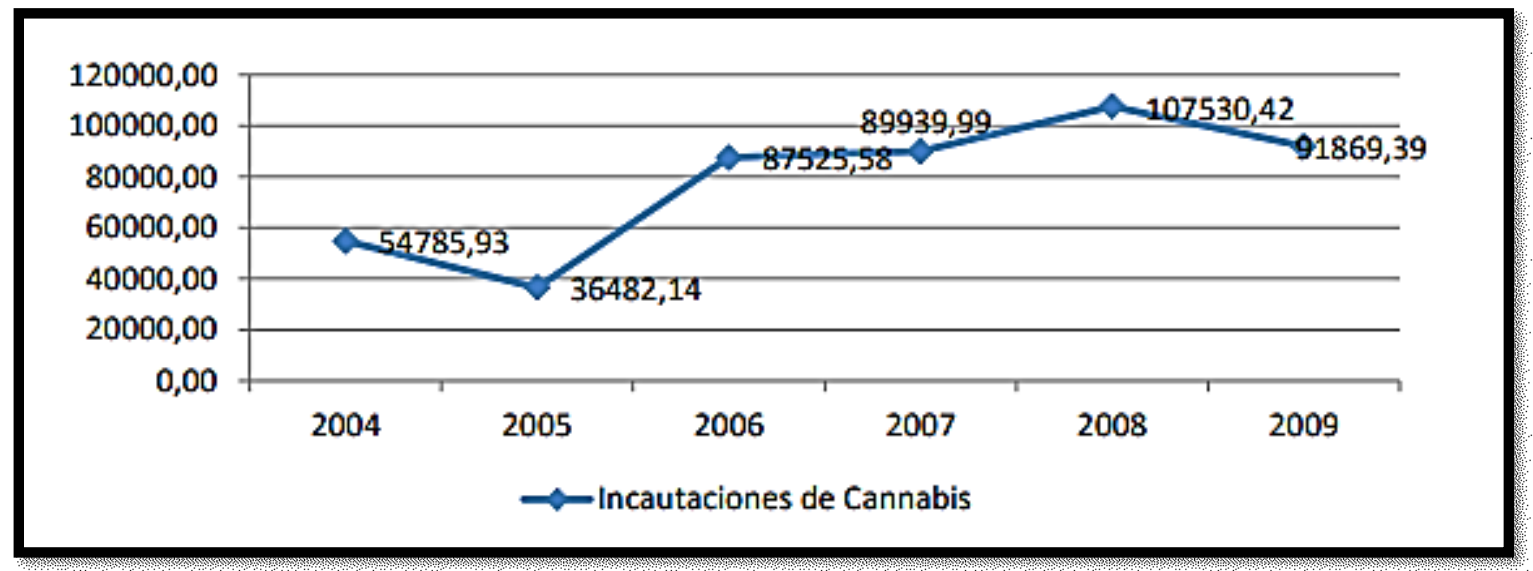

Por otra parte, a fin de observar la evolución de las incautaciones de cocaína, se presenta el siguiente gráfico. Aquí la evolución es mucho más rotunda, pasando de poco más de tres mil kilos en 2004 a más del cuádruple (12.643 kgs.) tan sólo cinco años después. En casi todos los países de Sudamérica las cantidades incautadas reportadas se incrementaron fuertemente en los últimos años, siguiendo los datos de Naciones Unidas. No obstante, exceptuando a Uruguay, que incauta cantidades pequeñas, Argentina es el Estado sudamericano cuya tasa de variación en esos cinco años es mayor, con un incremento de un 305\%. Empero, estos postulados deben tomarse con mesura, dado que la forma en que los países le reportan los datos a la UNODC puede afectar significativamente las variaciones entre ellos.

\section{Incautaciones de cocaína en kilogramos}

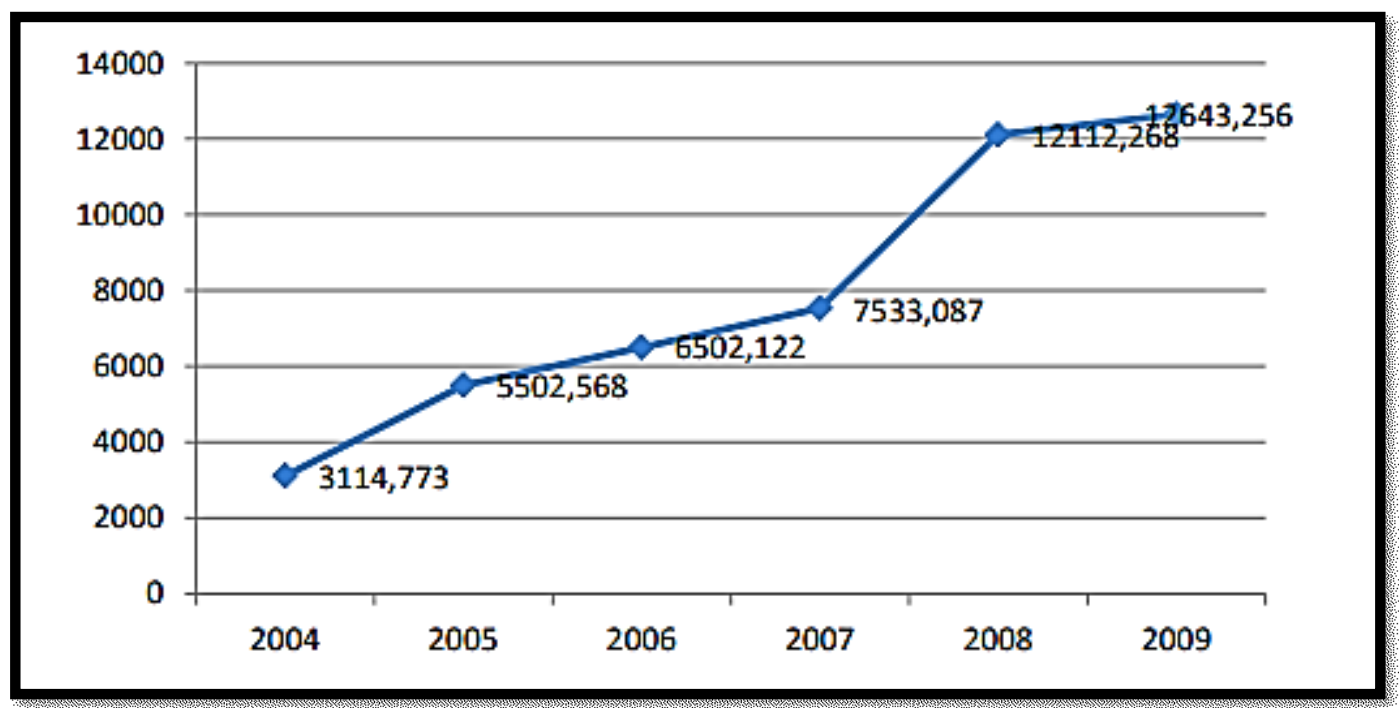

Pero más allá de las incautaciones, que pueden ofrecer una idea del nivel del tráfíco que se desarrolla en el país, es importante también prestar atención a la evolución de los niveles de Tesis de Maestría 
consumo. Por ello, el Gráfico III presenta la tasa de prevalencia anual19 para la marihuana, la cocaína y el paco. Como puede observarse, a partir de 2004 se observa un incremento considerable en las tasas de prevalencia, teniendo las mismas un fuerte punto máximo en el año 2006, alcanzando un 7,4\% de la población que en el último año había consumido alguna sustancia ilícita. Si bien luego los guarismos descienden y se estabilizan, nunca vuelven a los valores previos a 2004. Las tasas son mayores en hombres y en las poblaciones más jóvenes.

Según un reciente informe de UNODC, la tasa de prevalencia anual de cocaína en América del Sur $(1,3 \%)$ se halla en niveles comparables a los de Estados Unidos, aunque es mucho más al taque en Centroamérica $(0,6 \%)$ y el Caribe $(0,7 \%)$. El informe asevera que el uso de cocaína se ha acentuado significativamente en Brasil, Costa Rica y Perú, pero no ha sufrido grandes cambios en Argentina. Igualmente, destaca que para el cannabis Sudamérica posee una tasa mucho más alta que la media mundial, pues un 5,7\% de la población ha consumido esta sustancia en el último año. Además, para Europa Occidental y Central, zonas a donde suele considerarse que se dirige la droga que atraviesa Argentina, es de 1,2\%.

Tasa de Prevalencia Anual - Personas entre 15 y 64 años

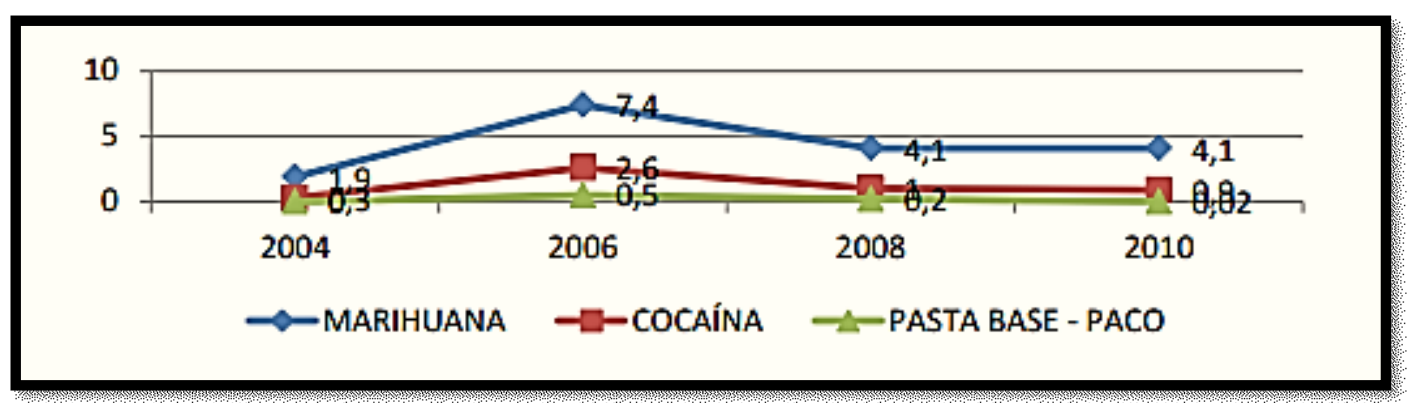

Una discusión que ha surgido recientemente en Argentina y que se ha adueñado de las campañas políticas y del tratamiento mediático referido al narcotráfico, es si Argentina sigue siendo un país de tránsito o se ha convertido en productor de estupefacientes. Al respecto, cabe aclarar que según la Convención Única de 1961 sobre Estupefacientes, enmendada por el Protocolo de 1972, existe una diferencia entre la producción y la fabricación de estupefacientes. La "producción" refiere a "la separación del opio, de las hojas de coca, de la cannabis y de la resina de cannabis, de las plantas de que se obtienen". La "fabricación" es posterior y hace referencia a "todos los procedimientos, distintos de la producción, que permitan obtener estupefacientes, incluidas la refinación y la transformación de unos estupefacientes en otros”. Por su parte, la SEDRONAR, clasifica los centros de procesamiento ilícito de estupefacientes en centros de producción ilícita, aquellos en donde se determine la presencia de hoja de coca, amapola de opio y otras especies de 
las cuales puedan extraerse estupefacientes $\mathrm{u}$ otros elementos necesarios para el cultivo y cosecha de las hojas de coca; centros de fabricación ilícita, aquellos en donde se detecte la presencia de precursores químicos empleados en la fabricación de estupefacientes o instrumental adecuado para su fabricación (cuando los centros se vinculen a estupefacientes de origen natural pueden ser de extracción, de purificación o de cristalización); y centros de adulteración, donde se encuentren sustancias empleadas en el estiramiento o corte, así como instrumental o precursores químicos para la adulteración.

El mismo estudio de la SEDRONAR realiza un análisis de un conjunto de causas judiciales y de ellas infiere la existencia de al menos cuarenta y tres centros de procesamiento ilícito de estupefacientes: treinta (68\%) vinculados a la adulteración o fraccionamiento y catorce $(32 \%)$ a la fabricación ilícita. De los centros de adulteración, un 46\% se halla en Buenos Aires, un 27\% en Córdoba, un 13\% en la Ciudad Autónoma de Buenos Aires (CABA), un 7\% en Salta y otro $7 \%$ en Tucumán. Es decir, se percibe una fuerte concentración en las grandes ciudades. Por otra parte, de los centros de fabricación un 72\% se encuentra en Buenos Aires, repartiéndose el resto entre Tucumán, Jujuy, CABA y Córdoba. No se verificó la existencia de centros de producción

El análisis de las causas muestra que los centros desarrollan sus actividades en instalaciones precarias que, no obstante, suelen estar separadas de las construcciones principales de las propiedades. No es raro tampoco que se instalen en casas quintas.

Por otra parte, según información otorgada por la Jefatura de Gabinete de Ministros de la Nación, en sus informes al Congreso de la Nación, entre los años 2000-2006, según las estadísticas de la Base de Datos Estadísticos de Procedimientos por Infracción a la Ley 23.737, se informaron un total de 80 centros de procesamiento ilícito. En cuanto a su ubicación geográfica, la gran mayoría se hallan en la Provincia de Buenos Aires (53), 8 en Capital Federal, 6 en la Provincia de Salta, 5 en la Provincia de Santa Fe, y el resto se distribuyen entre Córdoba, Tucumán, Entre Ríos y Jujuy. En el periodo 2012 se desarticularon 31 centros de procesamiento ilícito, mientras que en el año 2013, se informó la desarticulación de 14 centros de procesamiento ilícito de estupefacientes: 5 en Santa Fe, 1 en Mendoza, 1 en Salta, 7 en Gran Buenos Aires, 1 en la CABA. Asimismo, en el período 2000-2012 el 69\% de los centros de procesamiento ilícito se hallaron en Buenos Aires, y un 12\% en la CABA (Jefatura de Gabinete de Ministros de la Nación, 2014). El Gobierno también ha desmentido a la Junta Internacional de Fiscalización de Estupefacientes, que en un informe del 2012 arguyó que según estadísticas del propio gobierno la cantidad de centros de procesamiento se había acrecentado. 
Son justamente estos centros de fraccionamiento y adulteración los que son usualmente denominados como "cocinas".

En cuanto los laboratorios descubiertos durante el año 2013, se ve una prevalencia de las llamadas "cocinas", que son utilizadas para el fraccionamiento y la adulteración de la pasta base. En síntesis, puede percibirse que Argentina sigue siendo principalmente un país de tránsito de estupefacientes, con destino principalmente europeo y crecientemente hacia otras zonas. Sin embargo, la intervención en el proceso de las últimas etapas de producción de drogas mediante los precursores químicos sí se encuentra presente en Argentina.

Resulta innegable que también hay cierto nivel de elaboración de estupefacientes y dependiendo de la definición conceptual que se emplee puede hablarse de distintos niveles. Si se usa una definición acotada, como lo hace SEDRONAR, puede entenderse que lo que prima no es la producción, sino la fabricación y, principalmente, la adulteración y el fraccionamiento.

No obstante, incluso con esta definición acotada hay al menos un caso en donde se ha descubierto producción. Se trata de lo hallado recientemente mediante el llamado "Operativo Flipper" en donde en Funes, Santa Fe, se detuvo al llamado "Delfín" David Zacarías y se incautaron aproximadamente trescientos kilogramos de pasta base y clorhidrato de cocaína ya procesado, alrededor de mil trescientos litros de precursores químicos, dinero en efectivo y divisas extranjeras, varios vehículos automotores y un sofisticado laboratorio de producción de clorhidrato de cocaína, que poseía una secadora importada de grandes dimensiones, y una envasadora de vacío.

A propósito de este suceso, ocurrido en las cercanías de Rosario, es menester hacer mención al hecho de que Rosario, ubicada en la Provincia de Santa Fe, es tal vez la provincia que más difusión ha adquirido en lo relativo al narcotráfico. Ello se debe primordialmente a que ha elevado de forma abrupta sus niveles de violencia, hecho que se ve reflejado en la suba en la tasa de homicidios de la ciudad.

En 2004 Rosario experimentó 89 homicidios, valor éste que no ha parado de ascender: 108 en 2005, 90 en 2006, 113 en 2007, 121 en 2008, 130 en 2009, 124 en 2010, 169 en 2011, 182 en 2012 y más de 220 en 2013, elevándose así la tasa de homicidios a 15,1 cada cien mil habitantes, un valor muy alto si se considera que la media del país ronda los 5 por cada 100.000 y que en Buenos Aires es de 7,6 (Eventon, 2013). Hasta fines de septiembre de 2014, las víctimas de homicidio en Rosario ascienden ya a 19021. 
Siguiendo a Eventon (2013), es altamente probable que el incremento en los asesinatos sea producto de la competición territorial entre diferentes bandas, en particular entre la denominada "Los Monos", y otros grupos. El 70\% de los homicidios del pasado año se efectuó con armas de fuego y la mayor parte de las víctimas fueron hombres de entre 16 y 39 años, provenientes de las villas. Los Monos son quizá uno de los grupos más poderosos. Liderada por la familia Cantero, esta banda creció en la década del 90 a través de diversas actividades criminales como la importación de marihuana desde Paraguay. Hacia los 2000, adquirió todas las características de una organización criminal al comenzar a disputar territorio con otras bandas. Además, suelen reinvertir una parte de sus ganancias en las comunidades, como una forma de lograr legitimidad, asimilándose en ciertos aspectos al accionar estatal. Otra de las características de los grupos vinculados a las drogas en Argentina que también se refleja en Rosario, es la conexión con los denominados "barras bravas", quienes suelen intervenir como proveedores de violencia, soldados, o vendedores de drogas por ejemplo, al interior de los estadios. Los Monos han tenido contacto tanto con la barra de Rosario Centralcomo con la de Newells Old Boys, ambos clubes rosarinos.

Luego de varias disputas entre el gobierno provincial y el nacional, a principios de abril desde el Ministerio de Seguridad de la Nación se encaró un operativo de gran talante en la ciudad de Rosario, con el objetivo de ocupar la ciudad, con una presencia inicial de 3000 efectivos de distintas Fuerzas. Es muy reciente como para sacar conclusiones, mas hasta el momento el foco ha estado únicamente en el combate a los búnkeres y a los pequeños puntos de venta, y debe tenerse precaución con que no se genere el efecto globo, desplazándose el crimen hacia otras ciudades $^{76}$.

\section{Cómo penetran por la frontera con Bolivia los carteles del narco mexicanos y colombian os:}

Los grandes cargamentos de cocaína. Los vuelos clandestinos y la "lluvia blanca".

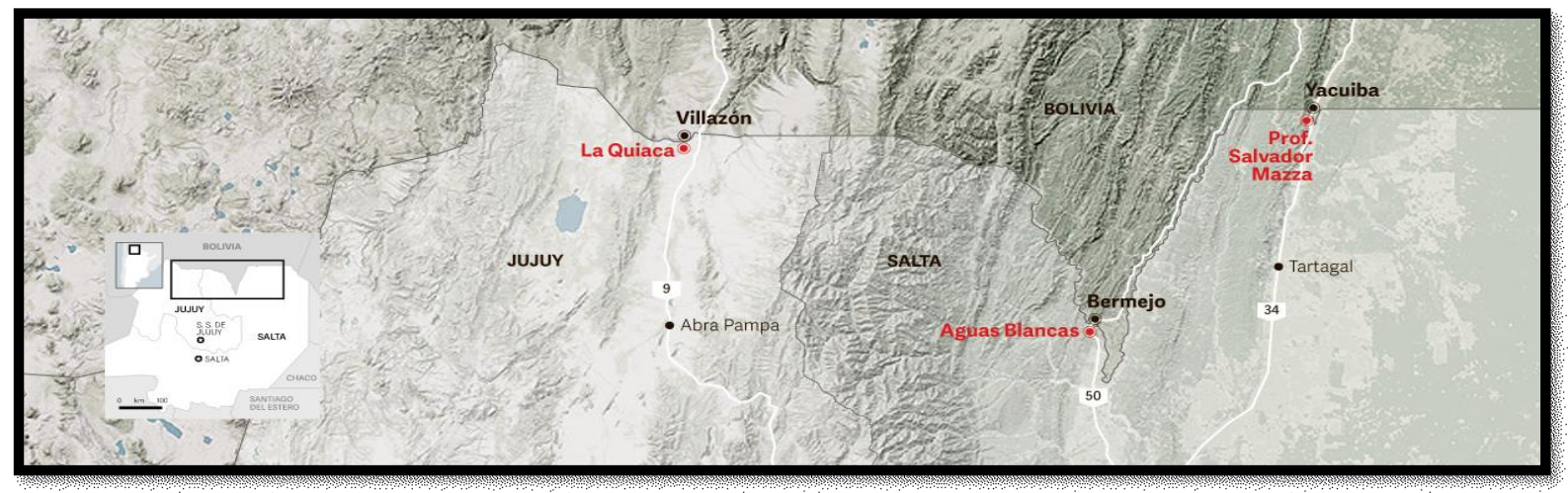

\footnotetext{
${ }^{76}$ Martín E. De Simone (2014) “Crimen Organizado en Argentina - Una mirada con perspectiva democrática y de los derechos humanos" - Argentina - Asociación Civil para la igualdad y la justicia

Tesis de Maestría
} 
La cocaína es como un camión cargado de ladrillos: por donde transita, va dejando el polvillo. Y acá en la quebrada que separa a la boliviana Yacuiba de la argentina Salvador Mazza se pueden ver claramente los pasillos por donde pasa el "bagayeo" tradicional de cualquier frontera del mundo junto al ahora incesante narcotráfico. Las cargas, en el lado boliviano, se acopian en galpones o simples cobijos armados con ramas y tirantes de algarrobos y palos blancos. Y comienza el juego del gato y el ratón.

Los "bagayeros" esperan el descuido del gendarme para atravesar la cañada por donde pasa un hilo de aguas servidas y correr entre la basura que ellos mismos tiran para impedir el paso de las patrullas. En apenas segundos están del lado argentino. Y allí van acopiando otra vez, medio kilo, dos kilos, un kilito más de pasta base o cocaína ya depurada.

Unos días más tarde el cargamento está listo. Un auto con 50 kilos camuflados donde antes estaba el air bag o el sistema de movimiento del asiento, los paragolpes, o simplemente dentro de latas de aceite, diluida en gasolina, embadurnada de dulce de leche, adentro de mil zapatillas. Si es posible lo recubren todo con resina plástica para evitar que los perros las detecten. Y allí comienzan a bajar tratando de sortear todos los controles que les pone Gendarmería y que convergen en el antiguo puesto de Aguaray.

Ahí, a 22 kilómetros de la frontera por la ruta 34, la ruta blanca, los gendarmes se convierten en verdaderos mecánicos expertos en armar y desarmar en minutos autos, camiones, motos y carritos. Para eludir el control, algunos bajan la carga, la pasan con "muleros" por entre los campos y la vuelven a cargar unos kilómetros después tratando de eludir las numerosas patrullas y baquianos.

A veces entregan un cargamento para llevarse otros tres. El que logra pasar va directo por esta ruta para entregar la carga a las bandas que operan en Santa Fe, Córdoba o el Gran Buenos Aires. La meta final es estar en menos de un mes en Madrid o Lisboa con 500 kilos de cocaína pura, el equivalente a unos 100 millones de euros. El primer bagayero recibirá veinte pesos por el tramo inicial del cruce de la cañada.

Los cuatriciclos de los gendarmes avanzan a toda velocidad por la quebrada binacional. Pasan el puente internacional por debajo y siguen hasta el límite máximo del paralelo 22. Ahí, en la punta misma, en el hito uno, en el paraje El Sauzal, en tierra de nadie, una banda de bolivianos, argentinos y colombianos había levantado hace un año una "cocina" en la que usaban el "método colombiano" de triturar las hojas de coca, pasarlas por acetona y gasolina hasta lograr la pasta base de la que, luego, se purifica y obtiene la cocaína. 
Se necesitan 500 kilos de hojas para lograr un kilo de cocaína.

En El Sauzal se encontraron dos "montañas" de casi diez metros de alto de hojas de coca desechadas después de ser trituradas y que se les sacara el jugo. De todos modos, esta "cocina" fue una excepción. Los grandes centros de elaboración de la pasta base están en Bolivia y Perú. Por detrás, siempre, aparece la conexión con algún cartel colombiano, particularmente el de Cali, o los mexicanos de Sinaloa. Y cuando quieren pasar un cargamento grande de cocaína pura que ya tienen colocado en España o Portugal (los principales mercados de entrada a Europa) utilizan la vía aérea. "Los aviones grandes van a campos de Santiago del Estero, donde muchos productores son cómplices, dicen que no se enteran de los aterrizajes pero por debajo reciben sus buenos billetes. Y los aviones más chicos vienen acá a Salta, a la zona de Anta, donde hay varias fincas buenas para bajar. Ya tienen todo montado. No se olvide que acá sólo en la zona de Orán residen unos 4.000 colombianos y algunos mexicanos que se dedican a controlar los envíos", explica un ex agente de la DEA, la agencia antinarcóticos estadounidense, que trabajó haciendo inteligencia en el norte argentino hasta que el gobierno nacional decidió no continuar con los acuerdos de cooperación. Los aviones sobrevuelan, lanzan su carga blanca y regresan a Bolivia. “Aquí hubo verdaderas lluvias blancas, de paquetes de cocaína. Yo tengo tres casos. Pero hubo muchos más en Jujuy, Santiago, Tucumán”, agrega el juez federal de Orán, Raúl Reynoso, que tiene a su cargo casi 7.000 casos relacionados con el narcotráfico.

\section{LAS CARGAS, EN EL LADO BOLIVIANO, SE ACOPIAN EN GALPONES O SIMPLES COBIJOS ARMADOS CON RAMAS Y TIRANTES DE ALGARROBOS Y PALOS BLANCOS.}

Es que en esta frontera confluyen todos los elementos necesarios para el narcotráfico. Del lado boliviano se produce la coca, unas 45.000 toneladas de hojas al año. De éstas, 20.000 toneladas son utilizadas por la población para el mascado de una bola de hojas, y para otros usos medicinales. "Las otras 25.000 se desvían para el narcotráfico", denunció la última semana el diputado opositor de la Convergencia Nacional boliviana, Adrián Oliva.

En Perú se producen 70.000 toneladas de hojas. Es el mayor productor mundial. Del lado argentino no crece el arbusto.

Una vez que se pasa la línea de Santiago del Estero, los cargamentos llegan en forma muy fácil hasta los puertos de salida de la producción de granos en toda la costa del Paraná y Buenos Aires. "Buscan barcos de cargas medianos y puertos donde no haya buzos tácticos. 
De esa manera, antes de arribar colocan la carga de drogas adosadas a la quilla con grandes sopapas o imanes. Cuando los inspectores suben al barco no encuentran nada.

La cocaína está debajo del agua y la sacan por la noche con la anuencia de algún vigía corrupto de algún puerto del Mediterráneo”, explica el profesor Edgardo Buscaglia, presidente del Instituto de Acción Ciudadana de México, quien elaboró un estudio sobre el narcotráfico en la Argentina en 2011 para Naciones Unidas.

Y a todo esto hay que sumarle los precursores y químicos varios con los que se refina la pasta base o se producen otras drogas como las metanfetaminas y que abundan en Argentina. De acuerdo con la consultora DataMyne, que recopila información sobre exportaciones e importaciones en el mundo, al país llegan 17 veces más químicos de los que necesita la industria local para su producción.

Sobrevolamos en helicóptero el tupido bosque salteño. Por la ruta 34 avanzan autos antiguos recargados hasta lo imposible con bolsas plásticas multicolores. Los gendarmes se suceden en tres puestos cada diez kilómetros hasta los scanners de última generación en Aguaray. Por la radio del piloto se escuchan informes de que hace un momento se decomisaron 60.000 dólares camuflados en una cubierta de repuesto; hacia el sur, por la ruta 34 detuvieron un Corsa con los paragolpes reforzados con 11 kilos de cocaína; en Rosario de la Frontera detectaron una Hilux robada en Buenos Aires para ser cambiada por droga junto a un BMW y un Audi, también robados en el conurbano. A éstos ya los conocían, pertenecen a la banda de César Villatalco conectado con narcos bolivianos y colombianos.

\section{LOS GRANDES CENTROS DE ELABORACIÓN DE LA PASTA BASE ESTÁN EN BOLIVIA Y PERÚ. POR DETRÁS, SIEMPRE, APARECE LA CONEXIÓN CON ALGÚN CARTEL COLOMBIANO y/o MEXICANO.}

De todos modos, los gendarmes celebran otra victoria después de meses de seguimiento de uno de los carteles más poderosos. El miércoles 20 lograron secuestrar cuatro avionetas que habían llegado a Santo Tomé, en Corrientes. Lo hicieron a través de Paraguay. Esa es ahora otra frontera caliente. En la última semana hubo tres enfrentamientos a tiros en el cruce del río Pilcomayo. “Argentina aún no tiene un nombre como país narco pero ya es un lugar importante para las operaciones de todos los grandes carteles internacionales y sus actividades aumentan a ritmo vertiginoso", comenta desde Washington Luis Sierra, el subdirector para investigaciones en el Hemisferio Occidental del Departamento de Seguridad Interior (Homeland Security). 
Abajo, en San Salvador de Jujuy, está el juez Carlos Olivera Pastor que tuvo un clásico ejemplo del accionar de los narcos mexicanos y colombianos. Hace unos meses, un guardia del juzgado número dos encontró una caja clásica donde se archivan los expedientes. Se la alcanzó a Olivera Pastor creyendo que se la había olvidado. Cuando el juez la abrió encontró una cabeza humana. Al mes siguiente, dos hombres golpearon salvajemente al secretario del juzgado. Olivera Pastor está desde entonces de licencia.

En julio del 2012 fue asesinado en Barrio Norte, Héctor Jairo Saldarriaga, "El Daga”, que había trabajado como sicario de Daniel “el loco” Barrera, el capo del cartel de Guaviare y el narco más importante de Colombia, hasta que fue arrestado hace unos meses en Venezuela. Ambos están relacionados tanto con la guerrilla de las FARC como con los paramilitares.

“ARGENTINA AÚN NO TIENE UN NOMBRE COMO PAÍS NARCO PERO YA ES UN LUGAR IMPORTANTE PARA LAS OPERACIONES DE LOS GRANDES CARTELES INTERNACIONALES Y SUS ACTIVIDADES AUMENTAN A RITMO VERTIGINOSO”

\section{EL “CHAPO” GUZMÁN, EL CAPO MEXICANO MÁS CÉLEBRE, TAMBIÉN TUVO SU INTENTO DE PENETRACIÓN EN FORMOSA, CERCA DE LA FRONTERA PARAGUAYA.}

Una semana más tarde también fue arrestada en Nordelta, Ruth Martínez Rodríguez, ex esposa de El Loco Barrera que intentaba enviar a Asia 280 kilos de cocaína dentro de unos muebles estilo Louis XV.

El "Chapo" Guzmán, el capo mexicano más célebre, que ocupaba la lista de la revista Forbes como el hombre más rico de su país con una fortuna de al menos mil millones de dólares, también tuvo su intento de penetración en Formosa, cerca de la frontera paraguaya. Envió a una mujer, María López Madrid, que puso en funcionamiento tres sedes de una llamada Iglesia Evangélica del Nuevo Milenio desde la que organizaban la entrada de cocaína y marihuana por Paraguay y la sacaban en lanchones de carga a través del Paraná.

"En Argentina hay seis carteles narcos ya instalados", dice Claudio Izaguirre de la Asociación Argentina Antidrogas. "Todo el este, con los puertos de Rosario, San Lorenzo, Ramallo, etc. está controlado por los colombianos; los mexicanos dominan el norte de Buenos Airesy son netos exportadores de cocaína a Europa; los bolivianos transportan desde el norte, controlan en Salta y operan desde el barrio de Liniers; los peruanos hacen lo mismo desde Jujuy hasta el bajo Flores; los dominicanos mezclan el menudeo con la prostitución y los garitos clandestinos con epicentro 
en Constitución; los argentinos pueden ser mediadores en todos estos negocios y hay una banda importante que se maneja desde Villa Soldati”.

El helicóptero avanza hacia Orán. Debajo, frente a la terminal de ómnibus está el primer centro de acopio de los "bagayeros", un enorme tinglado desde donde parten centenares de vehículos con todo tipo de mercadería para vender en las ferias como La Saladita. Entre medio están operando los narcos para seguir dejando el polvillo por todos los caminos hasta los puertos donde ese tonto ladrillo blanco se convierta en una fortuna o los lleve a la cárcel ${ }^{77}$.

\section{Los narcos se infiltran entre los "bagayeros" del norte argentino}

Lleva 80 kilos en una bolsa enorme que mantiene con la cabeza. El peso lo reparte entre la espalda y el cuello. El resto lo hacen las piernas fibrosas. Camina al trote por entre las piedras unos 2.000 metros. Descarga la bolsa sobre el techo de un viejo Torino reforzado y vuelve corriendo a buscar otra bolsa. René tiene 47 años e hizo esto toda la vida.

"Acá gano en un día lo que saco en una semana en la cosecha", dice este boliviano que cruza el río entre su ciudad de Bermejo y la argentina Aguas Blancas como si fuera de la cama al living. Junto a René están cargando la mercadería otros 100 o 200 hombres. Algunos, desde unos gomones que vienen del lado boliviano, otros a pie y con el agua a la cintura. Son los "bagayeros" que transportan el contrabando hormiga que se practica acá en esta zona desde siempre. La única diferencia es que ahora, por entre esos enormes paquetes comienzan a aparecer cargamentos de cocaína y pasta base que en menos de un mes tienen que estar a la venta en las calles de Madrid, Lisboa o París. "Nosotros no sabemos lo que hay adentro de las bolsas. Apenas las cruzamos", asegura René.

El Torino cargado como si fuera un equeco (el duende andino de la prosperidad) comienza su penoso viaje por la ruta 50 hacia Orán. El chofer sabe que en unos pocos kilómetros tendrá que pasar el control de los gendarmes y la aduana argentina. No tiene otros caminos alternativos. De un lado corre el río Tarija, del otro el río Pescado, los dos, luego convergen en el Bermejo. En el medio hay un laberinto de cultivos y caminos secundarios pero difíciles de acceder y todos terminan en la misma ruta. Pero hay una escapatoria temporaria. Un by pass, una travesía entre las cañas de azúcar. Siguen infringiendo la ley de contrabando pero no se exponen a las multas. “ Es apenas una concesión para mantener la paz social. Ya intentamos desbaratar todo esto pero casi incendian Orán. Desde entonces los dejamos hacer y los controlamos por todos lados”, explica un alto funcionario de Seguridad. "El problema es que por ahí sigue entrando una buena

\footnotetext{
${ }^{77}$ http://especiales.clarin.com/narcotrafico-la-argentina-blanca/ (primera parte) Tesis de Maestría
} 
parte de la pasta base y la cocaína, aunque sea cuentagotas", replica un ex agente de la DEA, la agencia antinarcóticos estadounidense, que trabajó en el norte argentino por años.

Los expertos aseguran que las grandes organizaciones colombianas, bolivianas, peruanas y mexicanas se están infiltrando entre los "bagayeros" y que muchos de éstos caen en redadas sin saber que están cargando en sus espaldas y por cobrar apenas 20 pesos más. "Hemos detectado narcotraficantes de 40 nacionalidades diferentes. Y se meten por todos lados. Pero lo que traen son cargas de no más de 50 kilos. Lo otro, lo grande va por el cielo”, comenta el juez federal de Orán, Raúl Reynoso. Aunque para Edgardo Buscaglia, profesor de la universidad de Columbia y consultor de Naciones Unidas, el peligro de que el narcotráfico se entrometa en estas viejas costumbres de fronteras latinoamericanas es que "comienzan a pirañizar la corrupción". "En Argentina no hay una corrupción piramidal o institucionalizada como hay en otros países de la región, es mas bien horizontal y extendida. Y sin un control férreo del Estado en todo el territorio, incluido el pueblo más pequeño, el gran dinero que maneja el narcotráfico carcome todo, como las pirañas, explica Buscaglia.

\section{"Las grandes organizaciones colombianas, bolivianas, peruanas y mexicanas se están infiltrando entre los "bagayeros" argentinos y bolivianos que cruzan la frontera por Salta"}

En la ruta 50 aparecen unos tinglados improvisados y una entrada a una tierra que dice pertenecer a una cooperativa aymara. Allí paran todos los autos repletos de bolsas para reiniciar el rito de los "bagayeros" que cargarán los bultos por casi tres kilómetros por un camino polvoriento y bajo 40 grados de calor con la intención de pasar el control aduanero de 28 de Julio. Una larga fila de más de 30 o 40 muchachos y algunas mujeres --un gendarme me cuenta que hay una bagayera que sigue trabajando y está embarazada de ocho meses y que hay otra que tiene 67 años - que avanzan al trote entre una nube de insectos y transpirando a chorros. Todos mantienen en sus bocas el acullico, la bola de hojas de coca que los ayuda a superar el momento. La escena se parece mucho a una imagen que acabo de ver en el museo del norte en la ciudad de Salta de una ilustración española de la mita, el sistema de trabajo esclavo del Estado Imperial de Tahuantinsuyo. Hago preguntas a los "bagayeros" pero se muestran muy hostiles. En el río llegaron a tirar unas cuantas piedras. Pero Marcos, un pibe argentino, me dice que "es la única manera que tenemos para sobrevivir". ¿Y no tenés miedo que te metan cocaína en la carga? "Y sí, pero hay que tomar el riesgo. Hay que vivir ", repite.

A 50 metros ya los están esperando los gendarmes. Los revisan uno a uno. Les hacen bajar el bulto y lo tajean con un cortante. Aparecen zapatillas de todos los colores y medidas, jarras 
plásticas, camisetas, repasadores, planchas, cintas de embalar, engrampadoras, baberos. Todo eso estará en unas horas en la Salada o en cualquier otra feria de su tipo alrededor del país. Hay un solo demorado porque en la mitad llevaba unas cuántas hojas de coca. "Los que llevan las cargas con cocaína se van por el lecho del río seco, acá sobre el Pescado. Pero es muy difícil que pasen. Ahí tenemos otros dos puestos de avistadores", comenta uno de los gendarmes. De todos modos los narcos siguen intentando y pasando. No hay método de vigilancia infalible en ninguna frontera del mundo. Convergen en Orán. Y enseguida pasan a Santiago del Estero donde cambian de vehículos y ya van "con carga segura" hasta Santa Fe o Buenos Aires, siempre con otros dos vehículos que le van marcando el camino. Tienen que evitar por todos los medios los scanners canadienses de última generación que tienen los puestos. Las imágenes que genera “desnudan” los vehículos y detectan la droga en más del 90\% de los casos.

Al final de la huella, entre el cañaveral y una plantación de bananos, los "bagayeros" van a entregar la carga a los mismos vetustos vehículos que seguirán el camino hasta la terminal de Orán. Subimos al helicóptero para avanzar por la ruta 40 y sobrevolamos el lecho seco y desértico del río Pescado. Se ven huellas de camionetas cuatro por cuatro.

Hacen ese recorrido por las noches usando baqueanos para intentar eludir los retenes móviles de la zona de La Mulita, cerca del lugar donde aparece el Bermejo. Si logran saltar el cerco de los gendarmes y la aduana se hacen millonarios de la noche a la mañana y entran en el imperio marcado por las dos "c": cárcel o cementerio.

Desde las esferas oficiales se admite que estamos ante un problema grave. Un alto funcionario de Seguridad dice que está más preocupado por el narcotráfico hormiga y las consecuencias que produce en la población argentina que los grandes cargamentos que parten para Europa u otros países latinoamericanos. "Ese pasa a ser un problema de los europeos, pero cuando queda acá nos destruye a nosotros", comenta. Y aclara que de todos modos está contenido con una gran presencia del Estado en todo el territorio. Pone como ejemplo los retenes de contención de la Gendarmería que están repartidos en todas las salidas de quebradas y caminos que llevan a las grandes rutas de acceso. El profesor Edgardo Buscaglia, de Columbia University, asegura que el problema no está en jueces y fiscales que, en general, son eficientes sino en "un sistema federal desarticulado y corrompido".

"Argentina incumple el 84\% de las reglas del protocolo anticorrupción de la Convención de Palermo de la ONU", asegura Buscaglia en una conversación desde Beirut donde está asesorando al gobierno libanés. Desde el gobierno nacional dicen tener muchas veces las manos atadas para 
actuar y se quejan de fiscales generales como el de la Cámara Federal de Casación que sostiene en el caso "Machado" (descubierto en Rosario con un cargamento de marihuana) que es "inconstitucional" revisar las pertenencias del interior de un automóvil cuando se busca drogas.

Luis Sierra, el subdirector adjunto para investigaciones del Homeland Security estadounidense, cree que más allá de toda consideración hay que "evitar por todos los medios que los narcotraficantes terminen asimilándose en el resto de la población. Buscan instalarse en ciudades afines y comienzan a corromper todo a su paso". El juez Reynoso está convencido de que para combatir el narcotráfico es fundamental contar con "el factor humano". Los gendarmes, policías y fiscales mejor preparados para detectar lo que los scanners, perros y retenes no pueden. "Un ojo entrenado y una mente no corrupta pueden revertir esta situación", sentencia antes de quedar nuevamente escondido entre los expedientes ${ }^{78}$.

\section{Argentina, ¿nuevo paraíso para el narcotráfico?}

Argentina pasó de ser un país de tránsito de droga a ser uno de los tres primeros exportadores de cocaína. La corrupción y la falta de políticas de Estado eficientes facilitan el trabajo de redes criminales.

Según el Informe Anual de las Drogas de la Oficina de Naciones Unidas contra la Droga y el Delito (ONUDD), Argentina es el tercer país más nombrado como lugar de producción de cocaína en diversas incautaciones llevadas a cabo en 2013. La ciudad de Rosario, en la provincia de Santa Fe, se ha convertido en un foco importante de narcotráfico, a raíz del cual se produjo un aumento de los actos de violencia derivados del lucrativo negocio de la venta de cocaína y de sus productos de desecho.

En esa ciudad, la tercera más poblada de Argentina, con casi 950.000 habitantes, se registraron 257 homicidios en 2013, un 40 por ciento más que en 2012, con una tasa de 22 muertes por cada 100.000 habitantes, según la agencia Télam. Ese incremento de la violencia es atribuido por algunos criminólogos al florecimiento del narcotráfico. Un estudio de la Universidad de Rosario indica que en esa ciudad existen más de 400 "kioscos" de droga, que rinden cerca de 2.000 millones de pesos (230 millones de euros) a sus operadores. Casi a diario se descubren nuevos laboratorios de droga, con una capacidad de producción de hasta ocho toneladas.

Pero no solo Rosario tiene un papel clave en la evolución del fenómeno del narcotráfico en Argentina. También en el norte, la llamada "Triple Frontera", donde Argentina limita con

\footnotetext{
${ }^{78} \mathrm{http}: /$ especiales.clarin.com/narcotrafico-bagayeros-del-norte-argentino/ Tesis de Maestría
} 
Paraguay y Brasil, es escenario del tránsito de cocaína, ahora también en gran medida hacia Europa, además de ser otro de los centros de lavado de dinero en el país. Solo en Argentina fueron detenidos más de 4.000 narcotraficantes en 2013, responsables del contrabando, acopio y comercialización, señaló el secretario de Seguridad del gobierno de Cristina Kirchner, Sergio Berni, quien también confirmó la existencia de 1.400 pistas de aterrizaje irregulares en la frontera norte que "podrían ser utilizadas por narcotraficantes".

Asimismo, informó sobre la incautación de más de 225.000 kilos de marihuana y de casi 20.000 kilos de cocaína en los últimos meses. Al aumentar la producción de drogas, especialmente de la cocaína y sus subproductos, como la pasta base (también llamada "paco"), se facilita también el consumo. Además, también aumenta la cantidad de personas de bajos recursos que consumen droga y trabajan distribuyéndola. Muchos de ellos son adolescentes y son llamados "soldados" por los traficantes. Diversos informes del periodismo de investigación en Argentina revelan, también, la existencia de sicarios profesionales al servicio de los narcotraficantes.

\section{Argentina, ¿productor de cocaína?}

Según la Dra. Adriana Rossi, especialista en narcotráfico e investigadora de la Universidad Nacional de Rosario (UNR), “Argentina no es Colombia ni es México, pero se ha insertado dentro del circuito del narcotráfico con mayor fuerza respecto de años anteriores". En los últimos años, explicó la experta en entrevista con Deutsche Welle, se ha producido una reorganización del narcotráfico, con la desestructuración de los carteles colombianos, el auge de los carteles mexicanos, y la aparición de nuevos corredores de drogas, sobre todo de la cocaína, que van hacia Europa, que entró de lleno en el consumo de esa droga, además de Asia, que también ingresó al mercado.

De acuerdo con la experta, los nuevos corredores de cocaína van desde Colombia y Perú, que producen materia prima y son también refinadores, pasando por Bolivia, Paraguay y Brasil, hacia la costa occidental de África, y de allí hacia Europa. La otra ruta involucra a Argentina y a Uruguay, por donde pasa la cocaína que llega a África y de ahí va hacia Europa y Asia. "Eso hace que Argentina tenga un rol más fuerte respecto de años anteriores. Al haber tránsito, la droga se desparrama, y eso hace que aumente el consumo", dice la experta. Rosario es un centro fuerte del consumo de drogas en Argentina desde 1996, fecha en la que se cuenta con estudios de la UNR, con un promedio más alto que todo el país.

Sin embargo, en Argentina "no hay producción de la planta de coca, sino refinación de cocaína a partir de pasta base, introducida desde Bolivia y Paraguay", dice Adriana Rossi. Por eso se están 
multiplicando las "cocinas" de droga, laboratorios artesanales para la producción local y el consumo interno. Allí la cocaína se produce a partir de pasta base, y también se "estira", es decir, se prepara para el consumo, la cocaína que llega en estado puro. En Rosario no hay grandes laboratorios: "Las cocinas artesanales se encuentran más en el Gran Buenos Aires o cerca de las fronteras", explica.

\section{Diversificación de las redes criminales}

Entrevistado por Deutsche Welle, el Dr. Edgardo Buscaglia, investigador principal (Senior Scholar in Law) en Derecho y Economía de la Universidad de Columbia, en Nueva York, y presidente del Instituto de Acción Ciudadana de México, explicó que la estructura de las redes criminales que operan en Argentina se ha diversificado. "No es solo el narcotráfico. Se trata de franquicias de grupos criminales que se han asentado en Argentina, tanto grupos asiáticos, con base en Guandong, China, como grupos latinoamericanos con base patrimonial en México, así como otros de El Líbano, que operan con impunidad en Argentina y se dedican al narcotráfico y a la trata de personas, al tráfico de armas, al tráfico ilegal de explotación minera, al contrabando de flora y fauna y al establecimientos de bases patrimoniales comprando tierras, que son algunos de los 17 delitos económicos detectados".

Según el experto, las redes internacionales actúan en Argentina involucrando a grupos locales que operan para ellos en la producción, la distribución y el sistema de transporte de las drogas. Estos grupos se han afincado en Argentina porque allí hay un nivel más alto "de impunidad patrimonial", es decir, que es más fácil llevar el dinero hacia el país, y no se aplican los castigos esperados. "Por eso Argentina atrae a ese tipo de empresas criminales que se dedican al contrabando, a la piratería, a la trata de personas, en lugar de atraer a empresas de alta tecnología, de software o de biotecnología", subraya el experto.

\section{Instrumentalización y políticas antidroga en Argentina}

"La droga se usó durante los años 90, en plena etapa neoliberal, como forma de control social en el conurbano bonaerense para evitar que surgieran posibles líderes de protestas sociales", señala, por su parte, Adriana Rossi. Hoy hay, además, una tendencia a la criminalización de la pobreza, ya que los búnkers o almacenes de droga están en las zonas paupérrimas, y la droga se vende a la clase media alta, que consume esas sustancias.

No hay medidas eficaces porque la problemática no se ha abordado de la manera correcta en la sociedad argentina, explica. Hay un proyecto de modificación de la ley actual en Argentina que 
no penaliza al consumidor, pero penaliza la tenencia, y allí se produce un debate sobre si la tenencia es para el consumo o para la venta, "y eso deja margen a grandes arbitrariedades de parte de los jueces, con lo cual las cárceles se llenan de consumidores”, subraya la investigadora, y añade que una comisión gubernamental elaboró una modificación de la ley para liberalizar el consumo, pero la misma "está durmiendo en un cajón porque parece que la sociedad aún no está preparada para aceptar una ley de ese tipo".

Edgardo Buscaglia dice respecto del rol del gobierno argentino en este desarrollo: "No creo que exista una conspiración por parte del gobierno argentino actual para dejar entrar a estos grupos. Creo que hubo mucho descuido, mucha corrupción política interna, se desmantelaron las instituciones del Estado aún más para que políticos pudieran llevar a cabo sus negocios corruptos. Además, se trata de neutralizar al sistema judicial, y Argentina no cuenta todavía con unidades de investigación patrimonial no financiera. Hay una serie de vacíos de Estado que han permitido que grupos internacionales entren a Argentina y operen con mayor impunidad que antes". Es así como Argentina se ha convertido en un "polo de desarrollo" del narcotráfico, que va en aumento.

\section{Beneficiarios y víctimas}

Los principales beneficiarios del narcotráfico en Argentina son, según Adriana Rossi, varios actores. En primer lugar, la economía, ya que "en Argentina hay lavado de dinero", y ese dinero dinamiza algunos sectores, por ejemplo, el de la construcción, como sucede en el caso de la ciudad de Rosario. Hay mecanismos que facilitan el lavado debido a la introducción subrepticia de capitales, que, evidentemente, movilizan el comercio y el sector de la construcción. "Algunos sectores de las fuerzas del orden, como la Policía, están atravesados por el narcotráfico y amparan el negocio, y eventualmente participa del mismo, recibiendo las coimas del narcotráfico, además de las coimas de la trata de personas", dice. "Eso hace que haya hechos de violencia que la policía no frena, creando una situación de desestabilización muy grave".

El otro beneficiario es el sector político, continúa la experta, "ya que no hay ningún negocio criminal de esta naturaleza que no tenga una anuencia de parte del poder político, ya sea, cerrando los ojos y negando la existencia del problema, o llegando a pactos de gobernabilidad, es decir, poniéndose de acuerdo el poder político y la policía para que la criminalidad no alcance niveles altos que provoquen críticas de parte de la población". Para eso, dice, se llega a acuerdos con el narcotráfico dándole vía libre para que desarrolle su negocio. "También se produjeron 
luchas entre bandas rivales de narcomenudeo, en las cuales se involucró la policía, y la situación se descontroló."

\section{La pista del dinero}

Para desestructurar las redes de narcos en la actualidad hay que hacer un seguimiento al dinero, agrega Adriana Rossi, "seguir la pista del dinero e investigar sectores de clase media, comerciantes, abogados, financistas, contadores que dibujan empresas fantasmas para el lavado y otros profesionales que gustosos prestan sus servicios a los narcos y aumentar de esta forma sus entradas y su prestigio social basado en lo que tienen, como propiedades y autos de alta gama". Según ella, se apunta, en cambio, a los jóvenes de las villas que venden o son "soldaditos" en un proceso de criminalización de la pobreza.

Según Edgardo Buscaglia, en Argentina el vacío de Estado en el sistema judicial, político y social favorece que se incremente el narcotráfico y faltan políticas de prevención del consumo, que "no deben ser punitivas, sino sociales". También señala que hay una falta de activismo desde el gobierno que permita abordar políticas masivas del prevención del consumo de drogas.

La represión no es la respuesta, sostiene Adriana Rossi, ya que, según ella, se reprime desde hace décadas, y eso no ha cambiado nada. Hace que las bandas retrocedan, pero éstas siempre encuentran una forma nueva de actuar. "En Argentina había bunkers, y ahora hay delivery o entrega de droga a domicilio. La droga no va a desaparecer, ya que vivimos en una sociedad consumista que busca el placer y la evasión, y la droga está instalada para quedarse", dice. "Si todo el dinero que se invirtió en la lucha antinarcótico se hubiera utilizado desde un comienzo en el sector de la salud, del desarrollo social y de la educación, estaríamos en otras condiciones"79.

\section{Ingreso de droga por la Ruta Nacional 34}

Una investigación del diario argentino El Clarín reveló los pocos controles que existen a lo largo de la carretera norteña, la Ruta 34, identificada por los oficiales como el principal punto de entrada de la cocaína a Argentina, y hogar de uno de los mercados domésticos que está creciendo más rápidamente en Latinoamérica.

La Ruta 34 argentina comienza en la frontera norte con Bolivia en la provincia de Salta, pasando por las provincias de Jujuy y Santiago del Estero, antes de recorrer toda la provincia de Santa Fe, para terminar en la ciudad de Rosario. Es una de las más importantes carreteras del país y uno de los principales corredores de transporte de carga que conecta con el norte del continente. Pero,

\footnotetext{
${ }^{79} \mathrm{http} / / / \mathrm{www} . \mathrm{dw}$. com/es/argentina-nuevo-para\%C3\%ADso-para-el-narcotr\%C3\%A1 fico/a-17734430 Tesis de Maestría
} 
también sirve para otro propósito. Las autoridades creen que los 1.488 kilómetros de carretera son usados por organizaciones narcotraficantes para llevar cocaína a las tres ciudades más grandes del país: Rosario, Córdoba y Buenos Aires. Juntas, estas ciudades y sus áreas metropolitanas representan casi la mitad (aproximadamente el 46 por ciento) de la población del país, y una gran parte del mercado de la cocaína.

El 17 de noviembre el diario bonaerense El Clarín publicó una investigación después de hacerle seguimiento a las declaraciones del exgobernador de Santa Fe, Hermes Binner, que dijo en octubre que el estatus de la Ruta 34 como la principal fuente de cocaína del país es un secreto a voces. Según el periódico, la importancia de la Ruta 34 para el narcotráfico es bien sabida entre los lugareños de las provincias de Jujuy y Salta, quienes se refieren a ella como la "ruta blanca" en referencia a las grandes cantidades de cocaína que son transportadas hacia el sur por la carretera.

Sin importar si el producto está destinado a consumidores locales o para el mercado europeo (del cual, Argentina se está volviendo un punto de tránsito cada vez más importante), la cocaína entra a través de la frontera con Bolivia, ya sea por Jujuy o Salta. El Clarín reporta:

"Por alli bajan los grandes cargamentos de cocaína desde Bolivia, que los narcos logran ingresar a la Argentina burlando los pasos fronterizos salteños de Salvador Mazza y Aguas Blancas, así como también el de La Quiaca (Jujuy), cuya ruta 9 se une con la 34 a pocos kilómetros del límite interprovincial entre Salta y Jujuy, sobre el río Las Pavas.

Hacia el norte de Salta, cuando la ruta atraviesa la localidad de Pichanal, se le une la maltrecha ruta nacional 50, que baja de Aguas Blancas. Forman un punto estratégico: si el narco logra pasarlo, sabe que los controles de la frontera ya quedaron atrás y tiene un $80 \%$ de posibilidades de llegar al destino con su cargamento de cocaína."

Al igual que sus contemporáneos en la frontera de México con Estados Unidos, los narcotraficantes en el norte de Argentina usan diferentes métodos para mover clandestinamente su producto. Los corresponsales de El Clarín encontraron que los camiones con cargamentos de cocaína viajan a través de la Ruta 34 en convoyes para evitar entrar en contacto con las autoridades:

"Las organizaciones narco -dice una persona que sabe del tema-, cuando envían un cargamento de cocaína mandan adelante un vehículo que va 'barriendo' la ruta y otro que va atrás a modo de custodia, ambos a una distancia de uno o dos kilómetros. El que va adelante, al 
ver un control rutero de los gendarmes, mediante teléfono satelital da alerta y el coche que está llevando la droga se detiene, o regresa al pueblo más cercano a esperar”.

No obstante, los encuentros con la policía son inusuales en la Ruta 34. En las seis horas que viajaron los reporteros de El Clarín, sólo vieron dos retenes de la policía, uno de los cuales estaba únicamente interesado en monitorear que los vehículos no excedieran el límite de velocidad.

Incluso en las raras ocasiones en las que los narcotraficantes se encuentran con las autoridades, usualmente son vistos más como competidores que como agentes encargados de hacer cumplir la ley. Según un oficial judicial de alto rango consultado por el diario, hay "muchos" policías federales y provinciales involucrados en el tráfico de cocaína en el área. 'El ‘chapeo' (mostrar una credencial para evitar la requisa) siempre dio buenos resultados porque hace que la droga camine sola a Buenos Aires", dice el oficial. En junio, por ejemplo, un policía federal fue arrestado en Salta por intentar traficar 110 kilos de cocaína.

No toda la cocaína que pasa por la ruta 34 entra en vehículos. Según la investigación de El Clarín, el tramo entre Colonia Dora y Selva en Santiago del Estero (ver mapa) es un lugar clave para el aterrizaje de vuelos con cargamentos de droga. El diario describe esta área como "crítica" en términos de control, señalando que los patrullajes de la policía empezaron apenas hace cuatro años, y que los sistemas de monitoreo aéreo son relativamente nuevos en el área.

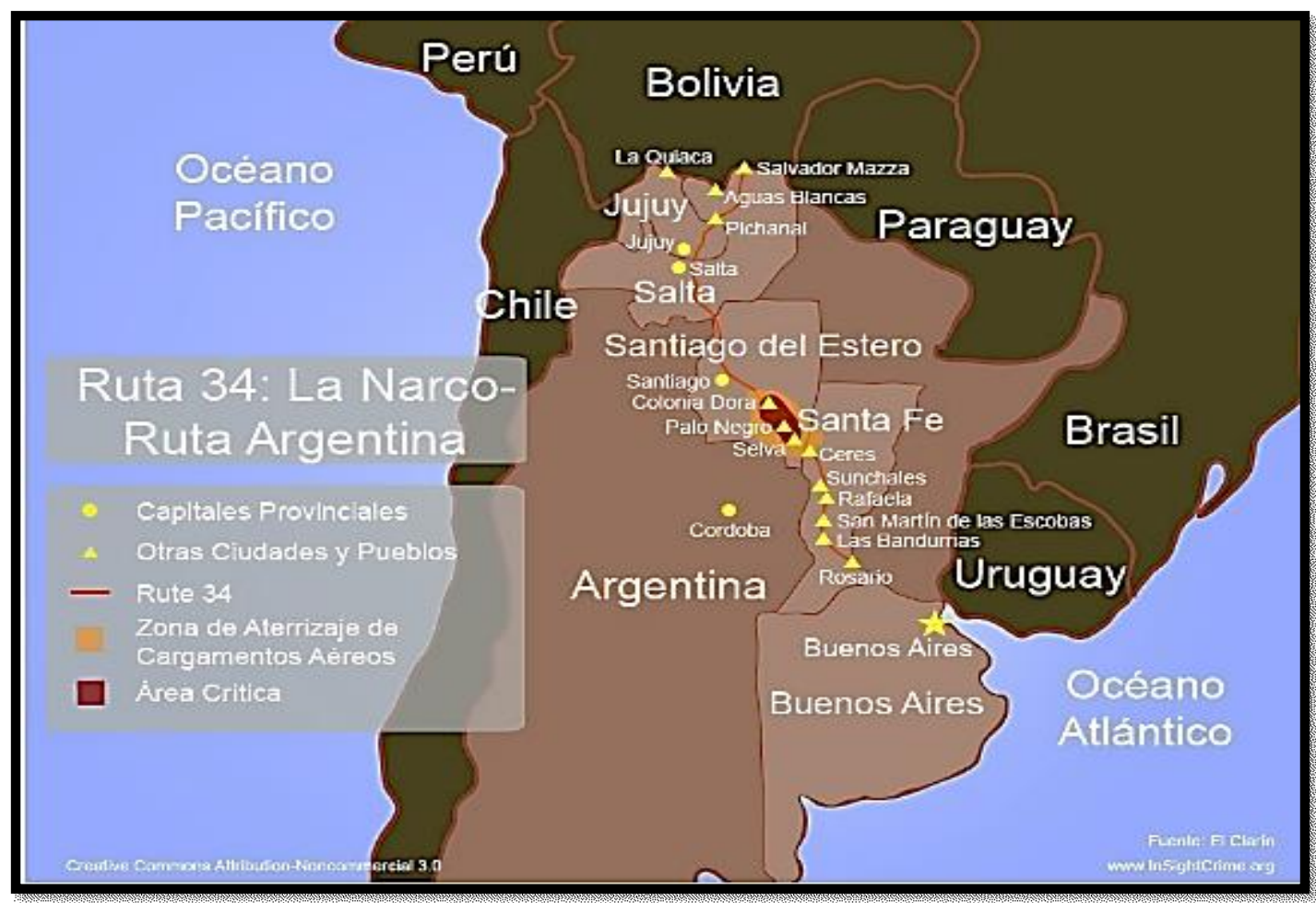


Como resultado, aeronaves con cargamentos de cocaína son capaces de aterrizar en pistas clandestinas cerca de la Ruta 34, y descargan en camiones que continúan hacia el sur por la carretera. Como reportó El Clarín, estas pistas se encuentran dispersas en ambos lados a lo largo de la carretera, y su pobre construcción hace que sean reemplazadas fácilmente si son descubiertas.

"Las "pistas" son improvisadas extensiones de unos 500 metros por 15, de tierra apisonada con un riel de 12 metros que pesa casi media tonelada (y que, en caso de apuro, suele quedar tirado al costado). Su extensión es suficiente para que pueda aterrizar (y luego despegar) una avioneta con hasta 500 kilos de droga.

Una vez lo cargamentos llegan a Rosario, en Santa Fe, están libres. Como reportó InSight Crime, la policía en Santa Fe es notablemente corrupta y los narcotraficantes encuentran poca resistencia en la provincia. El Clarín señala que los oficiales de Santa Fe llevaron a cabo una única incautación de droga en la Ruta 34 en todo 2011, y apenas han incautado 63.1 kilos de cocaína en lo que va corrido del año. Desde ahí los traficantes llegan con facilidad a Córdoba y a Buenos Aires.

El caso de la Ruta 34 arroja luces sobre las dinámicas a través de las cuales los narcotraficantes mueven su producto hacia Argentina, la cual se está convirtiendo cada vez más en un mercado importante de cocaína en la región. El consumo de cocaína en el país -especialmente el derivado producto, similar al crack, llamado "paco"- ha aumentado en los últimos años, duplicando desde 2007 el número estimado de consumidores. Según la Oficina de Naciones Unidas contra la Droga y el Delito, Argentina representa el 25 por ciento de la demanda doméstica local de cocaína en América Latina, haciéndola el segundo mercado más grande de la región, que representa el 33 por ciento ${ }^{80}$.

\section{EI narcotráfico encuentra nuevas rutas de paso a través de Argentina}

SALVADOR MAZZA, Argentina-En un día reciente en una zona rural de Argentina, unas bolsas blancas cayeron del cielo en una granja desde un pequeño avión. Alertada por un vecino, la policía encontró un colchón, un espejo, 393 kilos de marihuana y 27 kilos de cocaína envueltos en un plástico con un dibujo de la Torre Eiffel y la palabra "París".

Los narcotraficantes han transportado por aire cocaína desde los Andes a América Central y el Caribe durante décadas, variando sus rutas para evadir a las autoridades. Pero en un giro más

\footnotetext{
${ }^{80} \mathrm{http} / / /$ es.insightcrime.org/analisis/ruta-34-la-ruta-blanca-argentina-de-trafico-de-cocaina Tesis de Maestría
} 
reciente, han estado volando hacia el sur, desde Bolivia a Argentina, descolocando a las autoridades y convirtiendo este país del Cono Sur mayormente pacífico en un centro internacional de narcóticos.

"Los vuelos están trayendo cocaína todo el tiempo", dijo recientemente Pablo Gerardo Prado, un comandante de Gendarmería, la policía militarizada de fronteras de Argentina, mientras conducía una patrulla de vehículos todoterreno por un camino de tierra que separa a esta ciudad del norte del país de la frontera con Bolivia, el tercer productor mundial de cocaína.

La Argentina no produce cocaína, pero sus porosas fronteras, carreteras, ríos y puertos hacen que sea un buen lugar de tránsito. Las bajas probabilidades de procesamiento judicial también atraen a los narcotraficantes, dice Patricia Bullrich, ministra de Seguridad argentina.

Desde 1999, Argentina ha procesado con éxito sólo siete casos de blanqueo de dinero, según el último informe internacional de narcóticos del Departamento de Estado de Estados Unidos. Este historial ha inspirado a traficantes de Colombia, Perú y México a comprar casas de lujo y campos -donde pueden construir pistas de aterrizaje clandestinas-para evadir los controles más estrictos que existen en la parte septentrional de América del Sur y asegurarse así rutas de suministro rentables en el sur del continente, dicen las autoridades.

"En Argentina los narcotraficantes encontraron un lugar seguro para invertir. Vieron también la posibilidad de que desde la Argentina podrían también lucrar con el tráfico", dice Gustavo Lozada, un juez federal especializado en casos de narcóticos.

Durante la última década, Argentina se convirtió en el quinto punto de tránsito más importante para la cocaína despachada a Asia y Europa, de acuerdo con el más reciente Informe Mundial sobre las Drogas de las Naciones Unidas. "Traficantes colombianos y traficantes mexicanos en Argentina están tratando de establecerse en la región", dice Lizette Yriza-rry, subjefe de operaciones de la Agencia Antidrogas de EE.UU. en Washington. Las autoridades estiman que más de 70 toneladas de cocaína han pasado anualmente por Argentina en los últimos años.

"Estamos trabajando con los argentinos y con representantes de todos estos otros países de América Latina para tratar de frenar esa tendencia y no dejar que estalle en algo que sería entonces mucho más difícil de responder," afirma Yrizarry.

Según las autoridades, los traficantes compran pequeños aviones usados en Miami y los vacían. Los pilotos entonces vuelan hacia Argentina desde Bolivia y Paraguay para hacer lanzamientos 
del aire o por tierra en los caminos rurales y pistas de aterrizaje improvisadas. La carga se envía luego a través de los puertos locales a ciudades como Madrid y París.

El problema es tan grave que en enero el presidente argentino, Mauricio Macri, declaró una emergencia de seguridad nacional y firmó un decreto que permite a los aviones de combate derribar vuelos de drogas, una práctica controvertida que ya se utiliza en Colombia y Venezuela. Mientras tanto, el número de usuarios de drogas en el país se ha probablemente duplicado o triplicado desde 2000, según Ro-berto Moro, director de Sedronar, la agencia de abuso de sustancias del gobierno.

El año pasado en Buenos Aires, la capital argentina, 9\% de los estudiantes de 17 años o más dijo que había probado cocaína y el 45\% que había consumido marihuana, según un estudio. Un estudio similar en EE.UU. indicó que el 2,5\% y 35\% de los estudiantes de edad similar había probado cocaína y marihuana, respectivamente. Los argentinos también son únicos entre los latinoamericanos por el consumo de grandes cantidades de drogas sintéticas importadas de Alemania y Holanda, señala Yrizarry. La violencia de las bandas relacionadas con las drogas se ha convertido en un problema mayor. En 2014, las tasas de homicidio en Rosario, una ciudad portuaria desde donde se exportan drogas, llegó a 21 por cada 100.000 personas, tres veces el promedio de 2004, según los datos locales y nacionales.

Esta tendencia llevó al papa Francisco a advertir a su país natal a que no se convierta en otro México, donde los homicidios relacionados con las drogas han dejado más de 130.000 muertos desde 2006. Más allá de que el gobierno esté endureciendo su política contra las drogas, Argentina sigue siendo un país incomparablemente más seguro que México, dice Juan Gabriel Tokatlian, profesor de asuntos internacionales en la Universidad Torcuato Di Tella. Macri podría abrir una caja de Pandora, dice el experto, si se inclina por el enfoque de "guerra contra las drogas", que en otros países ha incrementado la violencia y los encarcelamientos, en lugar de reducir la demanda de drogas.

Los funcionarios argentinos, conscientes de estas preocupaciones, dicen que están tomando medidas enérgicas contra las organizaciones criminales pero no contra los consumidores, y que aumentarán fuertemente los fondos para los programas de educación y prevención de drogas. Los radares de la Argentina, que han operado a medio tiempo por muchos años, hasta hace poco cubrían sólo el 17\% del país, dejando puntos ciegos que los pilotos clandestinos podían explotar. Estos normalmente tiran los cargamentos de drogas en zonas de difícil acceso, dando a los 
traficantes en el terreno entre seis y 10 horas para recoger la carga y evitar ser capturados, dice Ricardo Toranzos, un fiscal federal.

Macri está agregando radares, mejorando el equipamiento de las fuerzas de seguridad y aumentando la cooperación internacional. El mes pasado, el Departamento de Estado de EE.UU. aprobó la posible venta de 24 aviones por US\$300 millones para patrullar la frontera.

Argentina también está comprando globos de vigilancia aérea israelíes y podría adquirir aviones de vigilancia estilo Awacs, dice Luis Green, que dirige el programa de seguridad en la frontera de la Nación.

El Congreso de Argentina también parece que va a penalizar el uso indebido de precursores químicos para fabricar drogas sintéticas. El proyecto de ley llega un par de años después de que el ex zar de la lucha antidrogas de la ex presidenta Cristina Fernández de Kirchner fue imputado por cargos de haber facilitado la importación masiva de efedrina, que los traficantes en México convierten en metanfetamina.

Bullrich dice que las nuevas reglas de derribo ya están asustando a los pilotos narco. Entre enero y abril, los radares detectaron 81 vuelos que potencialmente transportaban drogas, frente a los 219 detectados durante el mismo período del año anterior.

\section{Los escépticos dicen que el problema no va a desaparecer pronto.}

"Ni Macri ni Bullrich saben bien lo que está pasando", dice Marcelo Bergman, autor del libro Drogas, narcotráfico y poder en América Latina. "Al llegar a los traficantes en un lugar, aparecen unos meses más tarde en otro".

Para Luis Aguilar, un concejal de Colonia Elía, una pequeña ciudad a unos 80 kilómetros de la granja en la que aterrizaron las bolsas blancas, Macri está en el camino correcto.

"Hace años que vengo advirtiendo sobre los narco vuelos pero nadie me prestó atención", acusa Aguilar. "Tenemos que dejar de ser tan permisivos" 81.

\section{Bolivia y Argentina: Narcohistorias de frontera}

El nuevo Gobierno argentino ha declarado la guerra al narcotráfico, al menos formalmente, y desde el comienzo ha puesto especial atención a la frontera tarijeña y su actividad en los pasos de Aguas Blancas - Bermejo y Salvador Mazza - Yacuiba.

\footnotetext{
${ }^{81} \mathrm{http} / / /$ www.lanacion.com.ar/1935330-el-narcotrafico-encuentra-nuevas-rutas-de-paso-a-traves-de-argentina Tesis de Maestría
} 
El tema fue uno de los favoritos en la campaña presidencial de Mauricio Macri. También en la precampaña donde el periodista Jorge Lanata se cebó particularmente con el puesto del kilómetro 19, en su afán de fustigar a la ex presidenta Cristina Fernández de Kirchner. La ministra del Interior, Patricia Bullrich, ya hizo su primera visita a este lado del mundo para comprobar in situ las falencias y empezar a poner soluciones. La ley que permite derribar aeronaves que invadan el espacio aéreo ya está en vigor y ya ha sido aplicada y ha prometido, entre otras cosas, una medida tan básica como restaurar la Policía Federal en Orán.

Mientras tanto, el Gobierno boliviano se ha enzarzado en la enésima batalla con la Iglesia Católica a la que pide pruebas para demostrar la "penetración del crimen del narcotráfico en las estructuras del Estado", como reza la carta pastoral del mes de abril y que lleva la posición evangélica frente a la drogadicción y el narco como temas centrales. El texto cita al general retirado de la Policía Boliviana, René Sanabria, y al ex comandante de la Policía Boliviana, Óscar Hugo Nina Fernández.

Sanabria fue detenido en febrero de 2011 en la ciudad de Panamá cuando intentaba embarcar más de 140 kilos de cocaína a Estados Unidos; Nina está recluido en Palmasola desde 2015 por sus vínculos de alto nivel con el crimen organizado que no supo disimular

En los últimos meses se han sucedido varios operativos a ambos lados de la frontera, como los 20 kilos de cocaína en Bermejo y 400 de marihuana en Villa Montes de la pasada semana, y que sugieren una mayor coordinación entre las fuerzas y cuerpos de seguridad del Estado de ambos países, lo que no impide que se sigan trazando organizaciones criminales a ambos lados.

\section{SEJAS ROSALES Y REYNOSO}

El documento de los Obispos cita también a José Luis Sejas Rosales, hoy por hoy el acusado de narcotráfico más famoso en Bolivia y más buscado en la Argentina, que espera la extradición que se solicitó hace más de un mes, justo cuando un juez de La Paz procedía a dejarlo en libertad.

Sejas Rosales se convirtió de la noche a la mañana en un importante empresario del transporte en Santa Cruz, con una flota de hasta 275 vehículos y más de 90 camiones cisternas que habitualmente cruzaban la frontera por el departamento de Tarija. Su fama se hizo sentir en el Juzgado Federal de Orán, donde habitualmente se ventilan los casos de narcotráfico de la frontera. 
A Sejas Rosales se lo investiga, en total, por el ingreso de 500 kilos de cocaína y 30.000 litros de tolueno al país, precursor químico fundamental en la producción de cocaína y tiene abiertas un total de 11 causas en Orán, según los datos del periodista especializado, Ramiro Jiménez. En los últimos cuatro años, 11 camiones de cinco compañías ligadas a Sejas Rosales fueron secuestrados con droga en territorio argentino. Transanic, Trans GTI, Transporte JAC La Sierra, Creta y TransLand Cargo, son algunas de las firmas a las cuales se les secuestró cocaína. En Bolivia cobró notoriedad al constatar que había sido contratista de YPFB, por lo que el diputado Tomás Monasterios ha iniciado acciones cargando contra el actual presidente de la estatal petrolera, Guillermo Achá.

\section{DISTINTOS DESTINOS}

Libre y en Bolivia, Sejas Rosales compareció a voluntad propia ante el juez Erwin Jiménez por una causa distinta, legitimación de ganancias, abierta de oficio por la que fue remitido en septiembre de 2015 a la prisión de Palmasola de forma preventiva. El 10 de diciembre el Tribunal Supremo de Bolivia aprobó detener a Sejas Rosales con fines de extradición pero en el ínterin, el 23 de diciembre, Sejas Rosales es puesto en libertad condicional. No fue hasta el 20 de febrero cuando la Policía detiene a Sejas Rosales en Santa Cruz, en un operativo próximo a la vivienda del periodista Carlos Valverde. Hasta el momento se espera que se resuelva su extradición a la Argentina.

También espera el juez Reynoso. El caso Sejas Rosales colmó el vaso pero sus antecedentes venían de lejos. "Para que tu hermano salga en libertad hay que pagarle al Tío". Lejos de ser un hecho aislado, la exigencia de dinero a cambio de mejoras en la situación procesal de imputados en delitos vinculados al narcotráfico constituía una práctica habitual en el funcionamiento del Juzgado Federal de San Ramón de la Nueva Orán. Así lo entendió la justicia federal de Salta, que procesó con prisión preventiva a su titular, Raúl Juan Reynoso -el "Tío"- al considerarlo jefe de un aparato de poder enquistado en el mismo juzgado con el objetivo de obtener beneficios patrimoniales a cambio de conceder y/o gestionar resoluciones favorables a los imputados.

"Los bienes y la libertad de las personas quedaron a merced del magistrado quien seleccionaba los asuntos en función de la magnitud económica", señaló el juez federal, Julio Bavio.

Según el cuaderno de investigación, habría una tarifa "estándar" de 500 mil pesos argentinos, que le fue exigida a los imputados Bruno Mazzone, Sebastián Meneses e Iván Cabezas, sin embargo, en el caso de José Luis Sejas Rosales se habla de una tarifa de hasta 350 mil dólares. 


\section{UN CABO TARIJEÑO}

Desde el momento en que fue instaurado, Reynoso organizó el funcionamiento del Tribunal con personas de su extrema confianza, como son los casos del jefe de despacho Miguel Saavedra, considerado como la "mano derecha" del juez.

La estructura delictiva se completaba con abogados fuertemente relacionados a Reynoso: Ramón Valor, René Gómez, María Elena Esper y Arsenio Eladio Gaona, este último cuñado del juez, quienes oficiaban de intermediarios entre los imputados y el magistrado. Eran los encargados de difundir el monto exigido y la modalidad de pago.

De entre todos ellos, el rol de María Elena Esper, tarijeña de 72 años para más señas, es uno de los que más interés despierta ya que se le acusó de ser la principal testaferro, comprando propiedades de diferentes dimensiones en diferentes lugares. Esper, sobre quien se citó detención domiciliaria, niega las acusaciones pero elude hablar con la prensa "!No soy el Chapo Guzmán!”, cuentan las crónicas del día de su audiencia. Daniel Luna, representante legal de Esper, criticó el proceder del físcal. Sea como fuere, en junio se conocerá si el juez Raúl Reynoso recupera su plaza de juez en Orán o por el contrario va preso preventivamente, al igual que sus secuaces.

\section{ESTRATEGIAS DEL NARCO PARA CRUZAR FRONTERAS}

Las fronteras de Argentina con Bolivia y Paraguay contienen las principales rutas utilizadas por las organizaciones criminales para llegar al país con distintas drogas, cocaína y marihuana, principalmente.

Los traficantes, muchas veces "mulas", llegan cada día con sustancias camufladas a partir de distintas estrategias. Las cantidades oscilan entre un kilo y tres toneladas. Su destino: consumo interno, Chile por los pasos cordilleranos y exportación a otros países, desde los puertos nacionales.

Respecto a la droga que llega por aire, el Ejecutivo nacional confirmó que existen "1.400 pistas de aterrizaje declaradas, y 500 posibles pistas clandestinas".

La marihuana y la cocaína también, son transportadas a través de caminos terrestres. Siempre están escondidas en falsos fondos, en la carrocería de los autos, en cápsulas adentro del estómago, o disimuladas en las más distintas mercaderías. Por ejemplo, sobre la ruta nacional 34, durante un operativo que tuvo lugar en julio, encontraron droga oculta en botones. 
La actividad de los narcos en puntos clave del país, como las provincias de Salta, Jujuy, Corrientes, Formosa y Misiones, se puede analizar, entre otras variables, con las actividades de producción y la cantidad de droga incautada más allá de las fronteras, es decir, ya en territorio extranjero.

Un informe de EEUU señala que, aunque Colombia, Perú y Bolivia continúan produciendo el $100 \%$ de la coca utilizada para la cocaína a nivel mundial, los tres países redujeron la producción, y actualmente registran los números más bajos desde 1990.

La Fuerza Especial de Lucha Contra el Narcotráfico (FELCN) de Bolivia decomisó, entre enero y septiembre del año 2015, 17,7 toneladas de cocaína y 110,8 toneladas de marihuana. Además, detuvo a 2.445 personas en las operaciones antidrogas. Hubo más de 9.500 operativos y se destruyeron 4.000 laboratorios clandestinos. (Datos de INFOBAE).

\section{EL NARCO DEL CHACO, AMIGO DEL PODER}

El boliviano Wilson Maldonado Valderrama (68), objetivo principal de la operación "febrero blanco" de la que logró huir, era hasta hace poco el prófugo más buscado a ambos lados de la frontera. Hoy se suma a la lista de los narcotraficantes requeridos por la justicia argentina y deberá afrontar el proceso de extradición al igual que otro viejo conocido, Juan Carlos Sejas Rosales.

El historial delictivo de Wilson Maldonado Valderrama (68) se agranda en 1993 cuando es detenido en Buenos Aires con 27 kilos de cocaína de gran pureza, cinco años después fue absuelto en un polémico fallo que llegó hasta la Corte Suprema.

El 20 de marzo de este año Clarín titula a cinco columnas ““"W”, la cocaína que ya recorre medio país" y sitúa al empresario en la cúspide de "la red de narcos más activa del norte de Argentina". No es casualidad que el vehículo intervenido en ese operativo en Monte Quemado (Salta) con 267 kilos de cocaína hubiera pertenecido a otro diputado salteño, Ernesto José Aparicio, fallecido en 2013 y que en su oportunidad fue vinculado al asesinato de Liliana Ledesma que en numerosas oportunidades lo había denunciado por narcotráfico, Aparicio estuvo procesado por lavado de dinero.

El fiscal federal de Salta, Ricardo Toranzos, que sigue los pasos de la banda, identifica a Maldonado Balderrama como el dueño de la cocaína que estaba ingresando desde Bolivia en avionetas. Según explica, estas máquinas "bombardean” hasta 300 kilos por viaje en el monte salteño, principalmente en la zona de Anta. 


\section{LOS PASOS EN BOLIVIA}

Wilson Maldonado Valderrama, sin embargo, no contaba con hoja delictiva en Bolivia hasta que a principios de febrero la Policía lanzara la "operación Wiski” incautando bienes del prófugo por un monto de 2.762.107 dólares (\$us). El propio ministro de Gobierno llegó a Palmar Chico (Yacuiba) en esas fechas y brindó conferencia de prensa señalando que la decisión fue asumida después de que el Grupo de Investigación y Operaciones Especiales (GIOE) realizó un análisis financiero, seguimiento al movimiento económico y patrimonial del prófugo y se constató que era el propietario de dos haciendas con 30 cabezas de ganado vacuno y seis caballos, un aserradero con diez máquinas de carpintería, un surtidor de gasolina en Villa Montes y dos bienes inmuebles de pisos en la ciudad de Santa Cruz. Sobre si el prófugo se encontraba en el país, Carlos Romero eludió emitir criterio hasta que concluyan las investigaciones. Tampoco emitió mayores declaraciones cuando se procedió a su detención.

Lo cierto es que Wilson Maldonado Valderrama había logrado poner en pie dos empresas sometidas a supuestos estrictos controles por parte de las autoridades. "Chichín" como le identifican en círculos cercanos, es también un afamado criador de caballos de carrera, fundador del Club Hípico Villa Montes (municipio del sur boliviano) y admirado en su pueblo por la performance de su caballo preferido, "El Pata i Lana". Varias fuentes lo sitúan incluso en el centro del polémico caso en Villa Montes que costó el sacrificio de 6 caballos criollos al dar el cambiazo con caballos de raza contrabandeados desde la Argentina y detectados por el Senasag.

Su pasión por la equitación le ha llevado a labrar amistades con otros connotados jinetes del Chaco tarijeño. Uno de los más connotados es el subgobernador de Caraparí, Lorgio Torrez.

\section{ADJUDICACIONES MILLONARIAS}

Wilson Maldonado Valderrama ha ejercido como representante legal de diferentes consorcios constructores que se han adjudicado varios proyectos en el Chaco tarijeño donde habría figurado como representante legal.

Una de las más jugosas fue adjudicada precisamente en Caraparí y hace referencia a la Construcción del Camino Pavimentado CR. Canto del Agua Saladillo adjudicada por más de 22 millones de bolivianos a la Asociación Accidental Caraparí conformada por las empresas COSECA SRL (70\%) y Montaje y Construcciones Industriales LTDA (30\%) y que a la fecha ha sufrido más de media docena de modificaciones de contrato. 
Wilson Maldonado Valderrama fue apresado hace unos días en el barrio Héroes del Chaco de Santa Cruz de la Sierra. Lo curioso es que el juez que pide su captura internacional es el Juez Federal de Orán Raúl Reynoso, actualmente apartado de su cargo acusado precisamente de poner precio para conceder libertades a los narcos más frecuentes y habituados a cruzar la frontera.

\section{Narcotráfico gana territorio en Argentina}

En un contexto de aumento del consumo de estupefacientes, las organizaciones criminales se disputan el mercado local y sus actividades se vuelven más visibles; funcionarios y expertos en delitos complejos aportan una radiografía de un fenómeno que inquieta a la sociedad.

Uno de los temas más preocupantes para la sociedad es el avance del narcotráfico en la Argentina y la irrupción cotidiana de los casos relacionados con el tráfico de drogas. Es una cuestión que se metió en las conversaciones diarias, que por primera vez se transformó en un punto de debate en la campaña electoral, que se introdujo en las recientes conversaciones entre empresarios en el Coloquio de IDEA y que llevó a una veintena de universidades privadas a unir esfuerzos para el análisis.

LA NACION hizo una radiografía de ese fenómeno a partir de las opiniones de diez de los principales expertos que trabajan en diferentes campos frente a la realidad que impone el narcotráfico.

Claudio Mate, ex ministro de Salud de la provincia de Buenos Aires, estableció la tolerancia social como base del incremento del consumo de estupefacientes. Mientras que Sergio Berni, secretario de Seguridad de la Nación, hizo referencia a los nuevos peligros como consecuencia de las drogas sintéticas en el momento de evaluar posibles escenarios futuros.

Con su experiencia como juez federal, Guillermo Montenegro, ministro de Seguridad porteño, expuso que la mayor circulación de drogas en la Argentina forjó un cambio completo en el mercado local que derivó en más violencia callejera; en tanto que Carlos Gonella, a cargo de la Procuraduría de Criminalidad Económica y Lavado de Activos, pidió una ley que permita mejores herramientas para quitar la estructura económica narco.

Eugenio Burzaco, uno de los referentes de Mauricio Macri en temas relacionados al narcotráfico, y Diego Gorgal, con un rol similar en el equipo de Sergio Massa, apuntaron a los primeros pasos dados por los narcos tanto a nivel territorial como en las estructuras del poder. Horacio Calderón, especialista en delitos transnacionales, señaló que por sus características las bandas locales aún no tienen uniones firmes entre sí. 
El comandante general (R) Jorge Cabral, ex jefe de la división antidrogas de las Gendarmería, pidió no olvidar en las investigaciones el problema creciente del narcomenudeo, mientras que el secretario de Planificación de Salta, Néstor Ruiz de los Llanos, explicó los resultados obtenidos en su provincia a partir de la desfederalización de la lucha contra el narcotráfico.

En tanto, Claudio Stampalija, director del centro de Prevención del Delito de la Universidad de Belgrano, indicó que el narcotráfico impactó con fuerza en el cuerpo social argentino y eso llevó a las universidades privadas a unirse en un observatorio que analizará causas y efectos de las drogas en la Argentina.

Hoy el narcotráfico es una preocupación colectiva que merece un debate.

1. ¿Por qué aumentó el consumo?

Claudio Mate Ex ministro de Salud de Bs. As.

"Del universo de personas que consumen sustancias, una inmensa mayoría no incurrirá en consumos problemáticos, sólo en un grupo relativamente pequeño en proporción al universo de consumidores el uso adquiere características problemáticas." Quienes quieran entender la aceleración sin precedentes que el consumo de drogas ha tenido en la Argentina desde 2008, tienen en aquel concepto una primera pista. El mensaje -textual- corresponde al manual titulado "Prevención del Consumo Problemático de Drogas", que se distribuye en nuestras escuelas. Es como si las tabacaleras dijeran en las aulas de nuestros colegios que de los ocho millones de fumadores que hay en el país, solo 40.000 se van a morir este año. El resultado de estos enfoques es el que el hemisferio norte conoce desde la década del 90 como el derrumbe de la percepción de riesgo y el consecuente aumento del consumo.

En ese contexto, los índices de consumo de drogas en el resto del mundo se han estabilizado. Y en la Argentina crecieron entre un $20 \%$ y un $100 \%$, de acuerdo a quien los mida.

\section{2. ¿Cómo cambió el tráfico?}

\section{Guillermo Montenegro Ministro de Seguridad porteño}

Hace 20 años se juntaban todos en los juzgados para ver un kilogramo de cocaína secuestrado, y hoy esa cantidad se decomisa en cualquier lado. La situación es compleja, se perdió la capacidad de asombro. Cambió todo. Se modificó la estructura del negocio narco y también los delitos asociados. Aumentó el riesgo de violencia, especialmente entre los menores que son introducidos en el consumo y terminan como custodios de lugares de venta con baja expectativa de vida. 
Otro cambio es que la edad de inicio en el consumo de drogas bajó a 9 o 10 años y eso hace necesario que una estrategia contra el narcotráfico necesite de una lucha por arriba, con presión a las organizaciones criminales, y por abajo, con un fuerte trabajo social para prevenir el ingreso en las adicciones. Se requiere un trabajo interdisciplinario que involucre a todos los ministerios.

La situación actual lleva a la necesidad de establecer una emergencia en seguridad en todo el país, para coordinar planes inmediatos con los tres poderes del Estado y los gobernadores.

3. ¿Qué escenario se espera? Sergio Berni Secretario de Seguridad de la Nación

Las mafias de narcotraficantes están divididas en múltiples facciones, pero tienen un mismo objetivo: la provisión de logística para la generación de ganancias ilícitas.

Trabajamos día y noche para identificar, interrumpir y desmantelar las redes transnacionales que se aprovechan de nuestras sociedades abiertas para alcanzar los mercados establecidos en Europa y Estados Unidos. A diferencia de los que lanzan consignas poco realistas, nosotros estudiamos los expedientes judiciales e integramos las bases de datos de inteligencia criminal para entender de qué se trata el narcotráfico hoy. Y lo verificamos pragmáticamente en el terreno.

Para estar a la altura de lo que viene, que llevará sin dudas la marca de las llamadas drogas de diseño (drogas sintéticas), habrá que generalizar el modelo de "policiamiento guiado por la inteligencia criminal" que aplicamos a las fuerzas policiales y de seguridad federales.

Además, nuestro sistema de gestión del riesgo criminal requiere cada vez más de especialistas en investigación patrimonial y deberá ser modernizada también la Justicia.

4. ¿Hay zonas tomadas?

Diego Gorgal Ex ministro de Seguridad porteño

En la medida en que adquiere un peso mayor, en el narcomenudeo tienden a ocurrir dos situaciones: por un lado, se instala un mercado de provisión a cielo abierto, en el que los consumidores saben que pueden comprar droga; y por el otro, parte los grupos entran en disputa por esos lugares. Eso pasa frente al crecimiento del mercado doméstico que se ve en varios lugares, tanto en Rosario como en San Martín. 
En un momento las organizaciones se agrupan alrededor de servicios logísticos, entonces otros grupos pagan peaje para utilizar ciertas rutas o hacer circular determinadas cantidades de drogas. Pero la situación se agrava cuando el negocio aumenta.

Más allá de la violencia en algunas zonas, no hay información sobre lugares de nuestro país en los que los narcos ya se ubiquen consolidadamente en forma de "protoestado". En esos casos la ocupación primaria de ese territorio siempre es violenta porque se busca ejercer el monopolio del uso de la fuerza y la provisión de servicios y asistencia a los pobladores. La violencia está asociada a la penetración narco, porque se sabe que no puede controlar una zona la mano que no es capaz de reprimir la transgresión a una orden.

Eso es lo que hay que evitar, con situaciones complicadas en algunos puntos del Gran Mendoza y Jujuy, por ejemplo. Para hacerlo es necesario la reconstrucción de las comunidades en las que los narcos muestran mayor penetración.

Se puede revertir con un programa de ocupación y pacificación, con una primera etapa en la que debe desplegarse una fuerza de estabilización que garantice la vigencia de la ley.

5. ¿Penetró el narcotráfico al Estado?

Eugenio Burzaco Ex jefe de la Policía Metropolitana

Un buen indicador para entender el avance del narcotráfico es observar qué estructuras del Estado fueron cooptadas. Es que el crimen organizado busca mayores niveles de protección a medida que crece su negocio y asume territorialidad. Y hoy vemos que jefes policiales, intendentes y concejales están procesados o detenidos en varias provincias por su relación con organizaciones narcos. Incluso ya hubo sospechas de financiamiento de campañas políticas. El nivel de penetración en el Estado refleja el "momento" del narcotráfico.

Cuando el narcotráfico toma una dimensión superior hay más ocupación territorial, más violencia y en consecuencia se requiere mayor nivel de protección para esas operaciones. En una etapa posterior, el narco ocupa directamente el lugar del Estado. Es una penetración simbiótica que se vio en otros países. Aquí no se llegó a ese nivel, pero si no hacemos algo diferente en un período de 4 a 8 años estaremos en la fase en la que el narco reemplaza a las autoridades en muchas funciones. 
Si está claro que hoy no estamos en el escenario de un país de tránsito de drogas, en el cuál las bandas sólo tienen instaladas redes logísticas para la circulación de la mercancía hacia otros países. En ese momento al narco le alcanzaba con corromper a algunos policías o a quienes controlaban las aduanas. En esa etapa, la corrupción es más difícil de percibir, ya que la paga se recibe por no hacer algo o por mirar hacia otro lado. Sin embargo, con la territorialidad del negocio, producción y puntos de venta, la corrupción llega a otro nivel.

6. ¿Se puede combatir el lavado?

Carlos Gonella Titular de la Proselac

Nuestro país avanzó en materia de lucha contra el lavado de activos; el GAFI reconoció que tenemos un sistema consistente, una estrategia nacional. Pero esto no se alcanzó de un día para el otro: es el resultado de un proceso de por lo menos tres años. El Ministerio Público es parte del sistema. Las herramientas con las que cuenta son las procuradurías de Narcocriminalidad y de Criminalidad Económica y Lavado de Activos .

La metodología de "guerra contra las drogas" ha dado muestras de su fracaso en el mundo. En gran medida, la lucha contra el narcotráfico depende del éxito que tengamos en identificar, embargar y decomisar bienes productos, o instrumentos utilizados para, o destinados al uso del narcotráfico, o bienes de valor equivalente a cada uno de estas categorías. En otras palabras, depende de la capacidad efectiva de neutralizar la riqueza generada por esta actividad ilícita. La Procelac investiga, procesa y promueve casos de lavado de activos asistida por profesionales en ciencias económicas, antropología, sociología, criminología e informática.

Se han obtenido resultados importantes como el caso Carbón Blanco, en el cual se embargaron 160 millones de dólares. Hay varios casos más. Hay normas importantes, pero es necesario reforzar la legislación con modernos instrumentos que ya han dado resultado en otros países. Hay que sancionar una ley de extinción del dominio que permite extinguir, valga la redundancia, la titularidad de bienes que están a nombre de personas vinculadas al narcotráfico. La gente debe percibir que la riqueza generada por actividades tan perniciosas se neutraliza y se aplica en beneficio del bien común.

7. ¿Cómo se frena el menudeo?

Néstor Ruiz de los Llanos Secretario de Planificación de Salta 
En septiembre de 2013, mediante la ley provincial 7782, promovida por el Poder Ejecutivo, Salta adhirió a las condiciones previstas en el artículo 34 de la ley nacional 23.737, modificado por la ley 26.052, asumiendo así la competencia judicial en la atención de los delitos considerados de "microtráfico" de estupefacientes (venta de drogas ya fraccionada y en forma directa al consumidor). A casi dos años de entrada en vigor de la ley, y con la decisión política del gobernador Juan Manuel Urtubey de hacerse cargo de esta problemática únicamente con recursos provinciales, los resultados han sido positivos.

Por un lado, la consecuente creación de la Unidad Coordinadora de Lucha contra la Droga y Narcotráfico en el ámbito del Ministerio de Justicia permitió optimizar las acciones encaradas desde el Estado.

Integrada además por el ministro de Seguridad, ministro de Gobierno, secretario general de la Gobernación, la Agencia Antidrogas, procurador general de la provincia, miembros de la Corte de Justicia y de la Cámara Federal de Apelaciones (ellos mismos y no representantes), la Unidad Coordinadora es un espacio de trabajo articulado y de transmisión de información, para que las investigaciones no queden sólo en el último eslabón de la cadena.

Por otra parte, la modificación también el año 2012 del sistema procesal judicial con respecto al sistema de flagrancia, permitió la celeridad en los juicios. En la actualidad, un proceso de "microtráfico" dura en promedio dos meses, habiéndose ya condenado a más de 350 personas, lo que muestra a las claras la efectividad de este modelo de persecución penal.

8. ¿A qué apunta la investigación?

Jorge Cabral Ex jefe de Drogas de la Gendarmería

En nuestro país, la mayoría de los resultados de la lucha contra el narcotráfico se logran mediante el esfuerzo operativo de la interdicción, orientada, a veces, por una débil inteligencia operativa, pero se carece de investigaciones relevantes contra las organizaciones de narcotraficantes. La urgencia coyuntural sólo permite lograr resultados estadísticos en incautaciones y pocas detenciones de traficantes generalmente intrascendentes. Además, los datos e informaciones obtenidos no son utilizados por las fiscalías y juzgados para impulsar investigaciones que permitan llegar a los líderes de las organizaciones. 
Las fiscalías y juzgados federales continúan saturados de causas del tráfico ilícito de drogas, sin que se produzcan condenas ejemplares y decomiso de los bienes. Las investigaciones actuales se orientan a controlar el ingreso o egreso de drogas al país, pero aún no estamos preparados para combatir la producción y comercialización que se realiza en el territorio nacional. Las bases de datos no están integradas y son de difícil acceso para los investigadores.

9. ¿Cómo son las bandas?

Horacio Calderón Analista de delito transnacional

Las organizaciones o grupos locales dedicados al narcotráfico no tienen por el momento las estructuras organizacionales o modalidades habituales propias de las "Bandas Criminales colombianas" (conocidas como Bacrim), como tampoco de las Organizaciones Criminales Transnacionales (OCT) o cárteles de México.

La estructura organizacional de las bandas de narcotraficantes locales, en algunos, casos amorfa; varía según su magnitud y grado de sofisticación y poder, observándose en todas ellas una dinámica de cambio que dificulta su detección. Esa es una situación que se agrava por el hecho de estar constituidas por grupos familiares difíciles de infiltrar.

En cuanto a las "maras", hay tal vez ciertas formas incipientes de modalidad organizacional similares a las que operan en América Central.

En materia de inteligencia criminal y seguridad debería prestársele atención a grupos con las características de las maras, dado que la Argentina se ha transformado en un teatro de operaciones propicio, por el alto grado de corrupción y la laxitud penal vigente.

10. ¿Cómo reacciona la sociedad?

Claudio Stampalija Universidad de Belgrano

El problema del narcotráfico, como fenómeno criminal que se ha instalado en la Argentina cada vez con mayor visibilidad e impacto, ha logrado unificar preocupaciones y solicitar la acción clara y eficaz de las instancias gubernamentales.

En todos los ámbitos en que nos movemos diariamente observamos que la temática del narcotráfico, en sus distintas modalidades delictivas, tráfico, elaboración, consumo y lavado de dinero se ha introducido en las entrañas más íntimas de nuestro ser poniendo en serio riesgo a la 
familia y nuestros círculos sociales. Es como mirarnos al espejo y ver dos imágenes: la nuestra y la sombra que nos respira en la nuca con presagios intranquilizadores.

Y frente a esas imágenes los argentinos nos nucleamos y requerimos de nuestras autoridades la mayor de las atenciones y la promoción de políticas públicas integrales y eficaces, tal como también lo ha solicitado el papa Francisco. Y que nos ha impulsado, a su pedido, a un grupo muy importante de universidades y ONG que diera vida al Observatorio de Prevención del Narcotráfico $^{82}$.

El problema del narcotráfico en la Argentina ${ }^{83}$ : La Argentina no cuenta con un dispositivo policial unificado y especializado en el control del narcotráfico.

La situación del narcotráfico en la Argentina se enmarca en un contexto internacional que debe ser tenido en cuenta. No estaríamos indicando nada novedoso si dijéramos que el narcotráfico constituye una de las problemática criminales más complejas e intrincadas en el mundo moderno.

Durante las últimas décadas, el crecimiento y la diversificación de la producción, el tráfico, la comercialización y el consumo de drogas ilegales han sido significativos, y ello ha dado cuenta de las limitaciones y deficiencias de las estrategias de control inauguradas en los años '70 y profundizadas en los ' 80 y '90. El discurso belicista tan en boga en el ámbito internacional en cuyo marco el control del narcotráfico es abordado como una "guerra contra las drogas" encubre el fracaso de las políticas prohibicionistas.

Los acuerdos internacionales para el control de drogas están basados en esta impronta claramente malograda. Durante las últimas décadas, bajo esta égida guerrera se ha incrementado sensiblemente la población de consumidores de todo tipo de drogas prohibidas; se ha multiplicado la producción mundial de drogas ilegales así como la calidad de las diversas sustancias; se han estructurado una infinidad de mercados altamente estratificados por tipo y calidad de producto, por precio y por capacidad adquisitiva.

Se han diversificado las modalidades y los canales de tráfico y tránsito internacional de drogas prohibidas; se han extendido y dinamizado los grupos organizados delictivos abocados al negocio del narcotráfico; se han incrementado los márgenes de rentabilidad y de beneficios brutos y netos de estos grupos; se han extendido sin miramientos los circuitos de lavado de

\footnotetext{
${ }^{82} \mathrm{http}: / /$ www.lanacion.com.ar/1837544-narcotrafico-las-diez-preguntas-que-revelan-como-la-droga-gana-territorio-en-laargentina

${ }_{83} \mathrm{http}: / /$ www.forodeseguridad.com/artic/discipl/4161.htm

Tesis de Maestría
} 
dinero y de uso de los fondos provenientes del narcotráfico en actividades legales e ilegales; se ha extendido la corrupción política, judicial y/o policial vinculada al negocio del narcotráfico; se han profundizado los anacronismos y las deficiencias de las instituciones policiales ante la complejidad y el dinamismo del accionar de los grupos narcotraficantes.

En definitiva, la guerra y la criminalización ilimitada han generado un negocio fabuloso y le dan sustento a una de las empresas criminales más desarrollada del mundo moderno. Todo esto, además, ocurre en un contexto en el que el discurso belicista ha postulado como objetivo estratégico la derrota total del narcotráfico traducido en la desarticulación de mercados, consumidores, grupos delictivos y la desaparición de las sustancias. A eso, pues, le llamo fracaso.

Esta evidencia reclama una nueva mirada tanto global como específica que debe tener visos de innovación. Pero ello debe partir de una consideración fundamental: el crecimiento y la complejización del narcotráfico a nivel global ha estado básicamente determinado por la fabulosa demanda de drogas ilegales que se sostiene y amplía continuamente en los países centrales de mayor desarrollo económico, en particular, aquellos países del mundo occidental en cuya sociedades se han estructurados mercados de consumo minorista cada vez más extensos y diferenciados.

Sería una falacia insostenible afirmar que la oferta determina la demanda porque ello conduciría a "fetichizar" a la sustancia, a darle vida y a creer que ella, por sí mismo, crea las condiciones políticas, sociales, culturales y económicas para su consumo. De la única manera que los países periféricos en los que se producen y por los que se trafican algunas de las drogas ilegales ampliamente consumidas en los países centrales tengan un concernimiento responsable en el esfuerzo internacional tendiente a conjurar el narcotráfico es que se reconozca que en el plano internacional existen responsabilidades compartidas.

Los países del Cono Sur constituyen corredores de tránsito internacional de drogas ilegales. Así fue señalado por los principales organismos multilaterales especializados en la materia y por los gobierno de la región. No obstante, en los últimos tiempos, en estos países se han desarrollado nuevas tendencias dadas por el crecimiento del consumo y la articulación de mercados minoristas inexistentes hasta entonces; el aumento del contrabando de precursores químicos -en particular, en aquellos países como la Argentina que cuentan con una industria farmacéutica y química desarrollada-; y la conformación de ciertos circuitos y plazas auspiciosas para el lavado de dinero sucio. 
Ello, en alguna medida, ha estado apuntalado por el crecimiento relativo de la mayoría de nuestras economías pero también por algunas deficiencias institucionales que deben ser abordadas sin tapujos. El Doctor Aníbal Fernández, en ese entonces Ministro de Justicia, Seguridad y Derechos Humanos sostuvo apropiadamente que "en la Argentina, las políticas estatales [contra el narcotráfico] han sido de corte netamente represivo, han estado desprovistas de coordinación interjurisdiccional y han sido erráticas, encaminando sus esfuerzos en perseguir al consumidor", todo lo cual ha desembocado, según sus propias palabras, en "un total y rotundo fracaso, toda vez que los procedimientos son cada vez mayores pero las cárceles están llenas de adictos o pequeños comerciantes".

Ello ha sido así. En efecto, en la Argentina, la ausencia de políticas integrales en materia de control del narcotráfico ha respondido a ciertas deficiencias significativas cuya superación requiere de un conjunto de acciones institucionales básicas. En primer lugar, resulta indispensable el desarrollo de un cuadro de situación actualizado e integral del narcotráfico en el país, en todo lo atinente al tráfico, tránsito, comercialización y consumo de drogas ilegales así como a la producción y comercialización de precursores químicos y al lavado de dinero.

Dicho diagnóstico situacional debería desarrollarse en dos niveles en función de dos objetivos fundamentales. En el plano estratégico, a los efectos de dar cuenta de las problemáticas fenomenológicas del narcotráfico en función de la formulación de las políticas estatales de control de drogas ilegales. Y en el plano táctico, a los efectos de dar cuenta de las actividades y acciones concretas del narcotráfico así como de los grupos y redes narcotraficantes en función de una respuesta policial.

La experiencia regional nos indica que aquellos países que no tiene la capacidad de construir un diagnóstico situacional apropiado acerca de la situación del narcotráfico quedan a expensas de que dicho cuadro de situación sea realizado e impuesto por las agencias policiales y de investigación de los países dominantes de la región, siempre de acuerdo con sus perspectivas y con sus intereses, los que no siempre son convergentes con los nuestros.

Pero para ello se debe abandonar la tendencia política a negar u ocultar la problemática del narcotráfico bajo la perspectiva de que el reconocimiento público de su existencia y de su crecimiento coloca a los gobernantes en el banquillo de los responsables directos de dicha situación. En consecuencia, las problemáticas del narcotráfico deben ser incorporadas en la agenda gubernamental de seguridad pública como un asunto prioritario pero siempre a partir de 
un cuadro de situación autónomamente definido conforme las perspectivas e intereses nacionales.

En segundo término, parece necesaria la creación de una dependencia superior del gobierno que concentre las responsabilidades de formulación de las políticas y estrategias de control de drogas ilegales y las de conducción del sistema institucional encargado de su implementación, especialmente, en materia de seguridad pública e intervención policial. Ello, a su vez, debería ir acompañado necesariamente de la actualización y modernización de las bases legales y normativas del sector así como de la conformación de un servicio civil especializado en el control del narcotráfico. Como cualquier otro aspecto de la seguridad pública, las estrategias de control del narcotráfico no constituyen un asunto exclusiva ni predominantemente policial sino que configuran una cuestión política que debe ser definida, abordada y formulada por las autoridades gubernamentales.

Sin embargo, la reversión de la tradicional tendencia política a delegar la elaboración y ejecución de las acciones de control del narcotráfico en las agencias policiales hace imprescindible la ampliación de la capacidad de gestión gubernamental en el sector. Es en función de ello que adquiere relevancia la creación de una dependencia de gobierno especializada que sirva de instancia de conducción del sistema institucional y policial abocado a este conjunto de labores institucionales en nuestro país.

Finalmente, es indispensable emprender un profundo proceso de modernización policial tendiente a superar dos defectos que cercenan un accionar policial eficiente en la materia. Por un lado, el pronunciado anacronismo y desactualización orgánica, funcional y doctrinal de las instituciones policiales frente al aumento y la complejización del narcotráfico.

Y, por el otro lado, la existencia de bolsones de corrupción policial volcados a la regulación y protección de actividades delictivas de altísima rentabilidad económica, entre ellas, del narcotráfico. Nuestro país no cuenta con un dispositivo policial unificado y especializado en el control del narcotráfico, lo que, entre otras cosas, ha dado lugar -al menos en el ámbito federala una pronunciada fragmentación institucional cuya expresión más elocuente ha estado dada por la autonomía con que cada institución policial ha formulado e implementado sus propias estrategias y acciones de lucha contra esta problemática criminal.

Habría que evaluar seriamente y sin mezquindades organizacionales si no llegó la hora de conformar una Agencia Federal de Seguridad Compleja abocada a conjurar determinadas modalidades de la criminalidad organizada, entre ellas, el narcotráfico. Dicha agencia Tesis de Maestría 
conformaría un sistema integrado de conducción superior, de inteligencia criminal, de despliegue y labor operacional y de desarrollo táctico integrado del sistema policial dedicado al seguimiento de este conjunto de problemáticas.

Asimismo, no debería perderse de vista que la modernización institucional propuesta requiere de inversión pública destinada a afrontar los gastos que demanden la infraestructura policial adecuada, la formación y capacitación especializada del personal policial y el mejoramiento salarial del mismo. No se puede hacer frente eficientemente a la criminalidad de alta rentabilidad económica con instituciones policiales pobres, dotadas de presupuestos insuficientes que favorezcan el financiamiento ilegal de las mismas mediante la estructuración de mecanismos de recaudación ilegal de fondos. Ello abre la puerta para que las poderosas organizaciones criminales que están detrás de los negocios de referencia consigan controlar por medio de su fabulosa capacidad corruptiva a sectores o grupos policiales abocados a su control y desarticulación.

En fin, se trata de ir adecuando el andamiaje institucional tanto político como policial a los nuevos desafíos que se imponen en un tema tan sensible. Ello reclama abandonar la tradicional indiferencia política ante el tema y apropiarse de una problemática que ha sido históricamente gestionada por las instituciones policiales sin los resultados auspiciosos que todos esperamos.

El mapa Argentino de los narcos: Cómo es la ruta blanca de la cocaína que llega como pasta base desde Bolivia hasta purificarse en Buenos Aires. Panorama de las provincias con más “cocinas". En lo que va del año, ya se desbarataron 235. El rol de la Policía en el avance del narcotráfico en todo el país.

Un manual para estudiantes describe a la Argentina como un país que se caracteriza por la variedad que ofrece tanto a nivel geográfico como cultural. Su diversidad en el paisaje es muy amplia: desde cataratas, lagos y bosques, hasta desiertos de sal. Pero hay un mapa que no sale en los textos escolares: el de la producción ilegal de estupefacientes. De acuerdo con datos de la DEA, la Argentina sería uno de los 25 países que registran mayor producción de precursores químicos.

Hoy su producción se basa en la cocaína y, en menor medida, en drogas más complejas, como éxtasis y LSD. Según datos de la Secretaría de Seguridad de la Nación, durante el 2013 se desbarataron 235 "cocinas" en todo el país, una cifra que para diversos especialistas no sería ni el $10 \%$ de la real. 
El último informe de la Sedronar sobre "centros de procesamiento ilícito de estupefacientes" detalla que Buenos Aires, Santa Fe, Córdoba, Tucumán, Entre Ríos y Jujuy son las provincias que más cocinas de fraccionamiento y producción de narcóticos poseen. Según esta investigación, la mayoría de los lugares de adulteración se ubican en la provincia de Buenos Aires con el 46\%, a la que le sigue la Ciudad Autónoma de Buenos Aires (13\%), y las provincias de Córdoba (27\%), Salta (7\%) y Tucumán (7\%). El informe, publicado en 2011 y basado en ochenta centros en todo el país, agrega que los centros de fabricación se ubican en un $76 \%$ en la provincia de Buenos Aires, 7\% en la Ciudad Autónoma de Buenos Aires, y el resto en Córdoba (7\%), Tucumán (7\%) y Jujuy (7\%). Para actualizar el panorama, PERFIL consultó a especialistas en cada una de estas provincias de mayor producción.

Salta y Jujuy. Todo comienza en Bolivia. Más específicamente en los campos de coca de Yacuiba. Por su ubicación geográfica, las primeras provincias de la "ruta banca" son Jujuy y Salta. "Salta posee dos ingresos legales: la ciudad de Orán (a la altura de Aguas Blancas) y por la Ruta 34 (Salvador Mazza), donde se puede cruzar la frontera caminando por pasos no habilitados y hay tránsito de mercadería no controlada", indica Ricardo Toranzo, titular de la fiscalía federal $\mathrm{N}^{\mathrm{o}} 1$ de Salta a PERFIL. El funcionario especifica que en los alrededores del cauce del Río Seco hay barrios con movimientos muy fluidos "que hace que sean fronteras muy permeables y dificultosa para controlar".

El traslado es variado. En su mayoría "es terrestre, a través de mulas, camellos o en coches. También puede ser por vía aérea en pistas clandestinas o es arrojado desde el aire en zonas boscosa". Los búnkers aquí hacen un trabajo de refinamiento de estupefacientes de la pasta base de la hoja de coca (PBC). "La purificación en el país se debe a la facilidad que existe en el territorio de contar con precursores químicos (como carbonato de sodio y ácido clorhídrico) para esta etapa de elaboración del clorhidrato de cocaína". En la Argentina, no hay constancias de plantaciones de coca: "Se da más que nada en Colombia, Perú y Bolivia, mientras que el trabajo de los precursores químicos se encuentran en Argentina, Brasil y Ecuador”, aclara Toranzo.

El procedimiento de fraccionamiento puede repetirse varias veces, según la calidad buscada. "En el camino van quedando residuos que vuelven a comercializarse (el más impuro es el paco)", especifica Alberto Aragone, defensor público oficial ante el Tribunal Oral en lo Criminal Federal de Jujuy. En esta provincia, el punto de más traspaso se da en La Quiaca y para que el traslado Tesis de Maestría 
sea posible hasta Buenos Aires es esencial la Ruta 34. Este camino luego desemboca en Tucumán, Santiago del Estero, Córdoba, Rosario o Buenos Aires. En Santiago del Estero y Tucumán, según fuentes locales, se suele acopiar la droga y de allí se establece el transporte a grande urbes o al exterior vía aérea.

Córdoba. Los corredores más activos en la tierra cordobesa son por la Ruta 38. Las localidades lindantes como La Cumbre, Capilla del Monte, La Falda, Santa María de Punilla y San Marcos Sierra son destinos "comunes" para el arribo de marihuana, cocaína y otras sustancias ilegales. Otro corredor es el de la Ruta 9 Norte, con la Ruta 60, que es un corredor "histórico". "Sólo que en los últimos tiempos, se sospecha que la 38 empezó a ser más activa”, aclaró Juan Federico, periodista local especializado en narcotráfico.

Los alrededores del cementerio San Vicente (sudeste de la Capital, barrios Maldonado, Müller, Altamira, Colonia Lola, Bajada San José, Campo de la Ribera) forman la zona donde más proliferaron las cocinas de drogas. El periodista de La Voz del Interior le contó a PERFIL que las cocinas hace años "empezaron a disgregarse por todas partes, mucho al sur, en barrio Villa El Libertador y alrededores. Pero el sector más caliente es el de los alrededores del cementerio San Vicente".

Félix Crous, titular de la Procuraduría Adjunta de Narcocriminalidad, asevera que "la Policía es parte del Estado, con relaciones permanentes con la comunidad y ahí su involucramiento es muy evidente". El ejemplo del "narcoescándalo de Córdoba" es el más claro: hasta el momento, un comisario, un oficial y un suboficial se encuentran detenidos en el marco de la investigación por nexos entre policías, narcos y políticos. En esta provincia, en 2012 se incautaron casi 200 kilos de cocaína. Pero como parte del operativo Octubre Blanco, el mes pasado, se decomisó el mayor cargamento de drogas de la historia de Córdoba: 583 kilos de cocaína en la Ruta 9, cerca del norte provincial.

Santa Fe. En la cuna de la bandera, el principal ingreso de drogas a nivel terrestre se da por la Ruta 34, que atraviesa toda la provincia y termina en Rosario. Pero fuentes locales detallaron que "hay otras rutas alternativas donde se traslada la droga. También hubo casos de cargamentos por avionetas y barcazas".

Esta provincia sufrió lo que podría haber sido el peor golpe al Estado por parte de bandas narcocriminales: 14 balas calibre 45 que recibió la casa del gobernador Antonio Bonfatti el 11 de octubre. Hasta el momento hay tres detenidos, presuntos integrantes de bandas narco. En Rosario, los barrios más afectados por el negocio son Ludueña, en zona noroeste; Tablada, Tesis de Maestría 
Nuevo Alberdi y La Granada, al sur, y Las Flores, en el centro de la ciudad. Según la concejala del bloque radical María Eugenia Schmuck, en algunos barrios se sabe quién manda, pero otros no tienen dueño. En los últimos años se multiplicó la presencia de kioscos, casas precarias de venta de droga. "Aquí no hay bandas al estilo del Cartel de Sinaloa (México). En los medios nacionales, Rosario se vende como si fuera México, pero no está muy organizado el asunto. Hay mucho "imprevisto", especificó un periodista local y agregó que la red de comercialización y seguridad con los "soldaditos" es lo más establecido. Esto no quita el entramado de complicidad con otros sectores de poder: abogados, venta de autos de alta gama, contadores que limpian prontuarios, negocios inmobiliarios y protección de la policía provincial. Según la investigación Calles perdidas, de la Universidad Nacional de Rosario, \$ 1.500 por día cuesta la protección policial y \$ 300 gana un soldadito armado, mientras que uno desarmado gana 150. Este año, policías federales desbarataron "la cocina más grande en la historia país" en un country de Funes.

Buenos Aires. La próxima parada de la Ruta 34 es Buenos Aires. En los últimos meses, según la Policía Bonaerense, se decomisaron 17 laboratorios en la Provincia, hubo 18.269 procedimientos y se incautaron 28 mil pastillas de éxtasis. El comisario Rubén Darío García, inspector de prevención de la Superintendencia de Drogas Ilícitas de la Provincia de Buenos Aires, habló con PERFIL sobre la situación que se vive: "En los barrios es muy común la presencia de cocinas de estiramiento, más que de producción”. Cuando se le preguntó por las zonas más afectadas del interior, García indicó que Zárate y Campana son lugares que no poseen menos control, más que nada "social" . Aclara que en la Provincia hay mucho "contrabando hormiga". El menudeo se da de manera impensada: libros, langostinos, dulce de leche y frutillas. Para García, el crimen se organiza por zonas y no hay un armado de bandas a nivel nacional. Por su parte, el especialista y asesor en narcotráfico, Norberto Emmerich, explica que en Buenos Aires en general actúan carteles nacionales o en manos de población extranjera, como peruanos, paraguayos o colombianos. "Ellos producen acá porque buscan reducir costos de traslado y logística como cualquier empresa", agrega el especialista.

El negocio posee dos grandes escenarios. Uno es en los barrios más carenciados, donde, según Emmerich, "aumenta el consumo de paco, enraizado con fuerzas policiales, y la violencia. En San Martín, Villa La Cárcova, ya hay casi 20 chicos muertos en los últimos meses. Los vecinos aseguran que una de las bandas responde a "Rolón", que estaría protegido por el secretario de Seguridad de San Martín, José María Fernández. 
Otro escenario es el de los countries y el mercado de las drogas sintéticas, mayormente consumidas en fiestas electrónicas. Como el caso de la caída de un jefe de una banda narco, empleado de la agencia de viajes de egresados, Travel Rock que vendía cocaína, éxtasis, ketamina y efedrina en fiestas electrónicas.

Ciudad de Buenos Aires. El patovica Julio César Martínez llegó de Ibiza a Buenos Aires con un propósito: cocinar drogas de diseño. Así logró instalar "el primer laboratorio sintético en plena Ciudad de Buenos Aires", como lo calificaron las fuerzas de seguridad en septiembre. Este “operativo Ibiza” estaba encadenado con el empleado de Travel Rock. Más allá de la producción sintética, los barrios más pobres de la Ciudad viven un fenómeno similar a los de Provincia con “el nivel de adicción, la violencia y la connivencia con sectores policiales", afirma Luciana Pol, coordinadora de Políticas de Seguridad y Violencia Institucional del CELS. Los especialistas declaran que en Villa Soldati hay una fuerte presencia de ciudadanos de Paraguay; en Constitución, dominicanos; mexicanos en Puerto Madero; colombianos en Pilar; y peruanos en el barrio 1-11-14 de Bajo Flores. Aquí, el mes pasado, cinco personas murieron en un tiroteo. En Zabaleta, durante los últimos dos años, cinco chicos murieron en medio de un enfrentamiento, como el caso de Kevin de 9 años. Para Pol, la violencia es más fuerte en la zona sur (Villa Lugano, Soldati, Pompeya, Barracas) y la lógica se repite: "Las fuerzas llegan al barrio, hacen contactos y buscan protección" 84 .

\footnotetext{
${ }^{84} \mathrm{http} / / /$ www.perfil.com/elobservador/el-mapa-de-la-argentina-de-los-narcos-1116-0062.phtml Tesis de Maestría
} 


\section{CAPITULO V:}

\section{APLICACIÓN Y ANALISIS DE LA MATRIS FODA EN EL PROBLEMA DEL NARCOTRAFICO EN BOLIVIA Y ARGENTINA:}

\section{$\underline{\text { Análisis FODA }^{85}}$}

El Análisis FODA es una metodología de estudio de la situación competitiva de una empresa en su mercado (situación externa) y de las características internas (situación interna) de la misma, a efectos de determinar sus Fortalezas, Oportunidades, Debilidades y Amenazas.

En nuestro caso analizaremos y estudiaremos la situación de los estados de Argentina y Bolivia con relación al problema del Narcotráfico, si bien a lo largo del presente trabajo fuimos detallando la problemática sobre el narcotráfico en cada país, en esta parte buscaremos hacer una leve mención de esta situación en lo que respecta a las Fortalezas, Oportunidades, Debilidades y Amenazas que presenta cada territorio.

La situación interna, el estado actual que presenta cada nación (Argentina y Bolivia) se compone de dos factores controlables: fortalezas y debilidades, mientras que la situación externa se compone de dos factores no controlables: oportunidades y amenazas.

El análisis FODA es la herramienta estratégica por excelencia más utilizada para conocer la situación real en que se encuentra una organización.

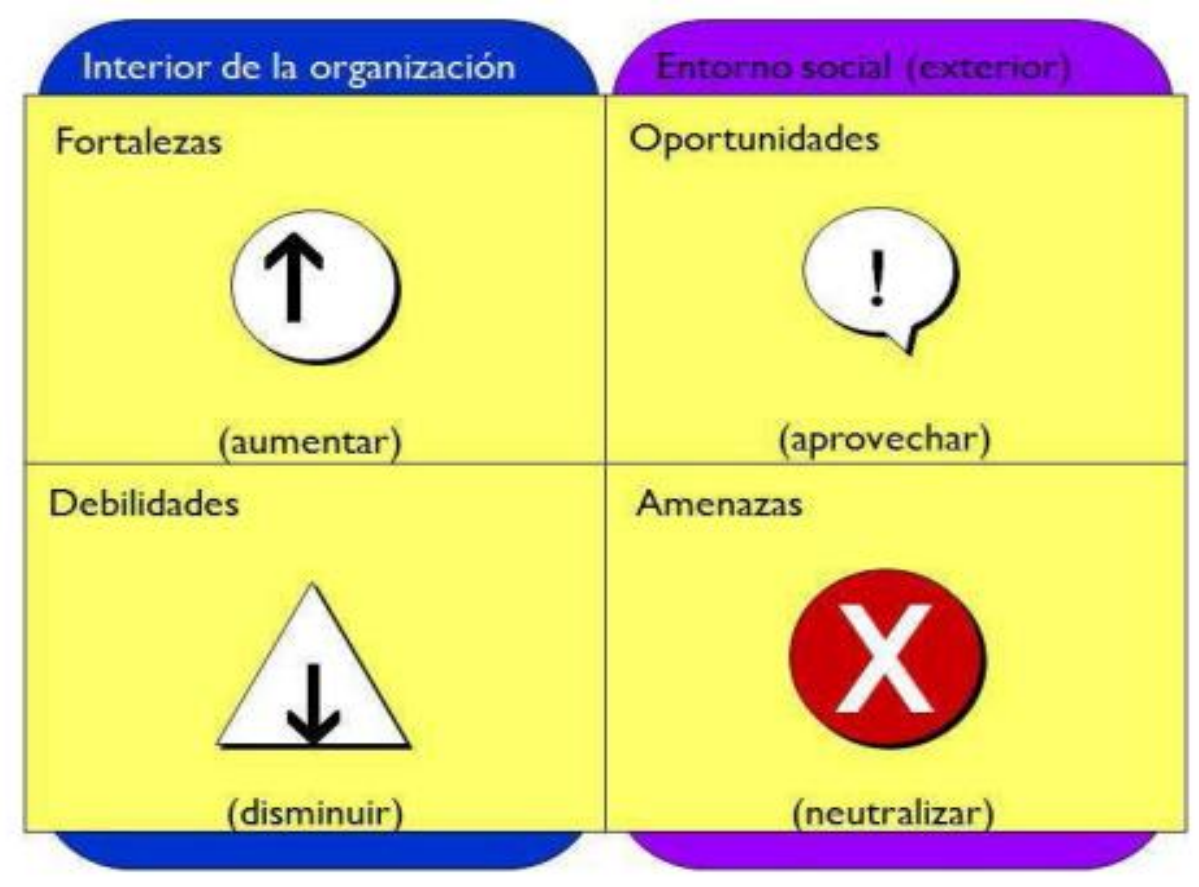

\footnotetext{
${ }^{85} \mathrm{http} / / /$ planeamiento.uncoma.edu.ar/images/phocadownload/ReunionDecanos20160505/Aprenderapensar-AnlisisFODA.pdf Tesis de Maestría
} 
El análisis consta de ciertos pasos:

- Análisis Externo

- Análisis Interno

- Confección de la matriz FODA

1. Análisis Externo La organización no existe ni puede existir fuera de un ambiente, fuera de ese entorno que le rodea; así que el análisis externo permite fijar las oportunidades y amenazas que el contexto puede presentarle a una organización.

Siempre que nos referimos a Oportunidades y Amenazas hacemos referencia a las que tiene el Estado para lograr la finalidad de contrarrestar el avance del narcotráfico

\section{Oportunidades}

Las Oportunidades son aquellas situaciones externas, positivas, que se generan en el entorno y que, una vez identificadas, pueden ser aprovechadas. Algunas de las preguntas que se pueden realizar y que contribuyen en el desarrollo son:

¿A qué buenas oportunidades se enfrenta el estado?

¿Contamos con la información necesaria sobre el narcotráfico?

¿Existe una coyuntura en la economía del país?

¿Qué cambios de tecnología se están presentando en el mercado?

¿Qué cambios en la normatividad legal y/o política se están presentando?

¿Qué cambios en los patrones sociales y de estilos de vida se están presentando?

\section{$\underline{\text { Amenazas }}$}

Las Amenazas son situaciones negativas, externas al programa o proyecto, que pueden atentar contra éste, por lo que llegado al caso, puede ser necesario diseñar una estrategia adecuada para poder sortearla.

Algunas de las preguntas que se pueden realizar y que contribuyen en el desarrollo son:

¿A qué obstáculos se enfrenta el estado?

¿Qué están haciendo los competidores (personas que se dedican al narcotráfico)? Tesis de Maestría 
¿Se tienen problemas de recursos de capital?

¿Puede algunas de las amenazas impedir totalmente la actividad del estado?

2. Análisis Interno Los elementos internos que se deben analizar durante el análisis FODA corresponden a las fortalezas y debilidades que se tienen respecto a la disponibilidad de recursos de capital, personal, activos, calidad de producto, estructura interna y de mercado, percepción de los consumidores, entre otros.

El análisis interno permite fijar las fortalezas y debilidades de la organización, realizando un estudio que permite conocer la cantidad y calidad de los recursos y procesos con que cuenta el ente.

Para realizar el análisis interno de una corporación deben aplicarse diferentes técnicas que permitan identificar dentro de la organización qué atributos le permiten generar una ventaja competitiva sobre el resto de sus competidores.

\section{$\underline{\text { Fortalezas }}$}

Las Fortalezas son todos aquellos elementos internos y positivos que diferencian al programa o proyecto de otros de igual clase.

Algunas de las preguntas que se pueden realizar y que contribuyen en el desarrollo son:

¿Qué ventajas tiene la empresa?

¿Qué hace la empresa mejor que cualquier otra?

¿A qué recursos de bajo costo o de manera única se tiene acceso?

¿Qué percibe la gente del mercado como una fortaleza?

¿Qué elementos facilitan obtener una venta?

\section{$\underline{\text { Debilidades }}$}

Las Debilidades se refieren, por el contrario, a todos aquellos elementos, recursos, habilidades y actitudes que la empresa ya tiene y que constituyen barreras para lograr la buena marcha de la organización.

Las Debilidades son problemas internos, que, una vez identificados y desarrollando una adecuada estrategia, pueden y deben eliminarse. 
Algunas de las preguntas que se pueden realizar y que contribuyen en el desarrollo son:

¿Qué se puede mejorar?

¿Que se debería evitar?

¿Qué percibe la gente del mercado como una debilidad?

¿Qué factores reducen las ventas o el éxito del proyecto?

\section{Elaboración de una matriz FODA}

\begin{tabular}{||c|c|c|}
\hline Análisis FODA & Fortalezas & Debilidades \\
\hline \multirow{2}{*}{ Análisis Interno } & $\begin{array}{c}\text { Hacer lista de } \\
\text { fortalezas }\end{array}$ & $\begin{array}{c}\text { Hacer lista de } \\
\text { debilidades }\end{array}$ \\
\hline \multirow{2}{*}{ Análisis Externo } & Oportunidades & Amenazas \\
\cline { 2 - 3 } & $\begin{array}{c}\text { Hacer lista de } \\
\text { oportunidades }\end{array}$ & $\begin{array}{c}\text { Hacer lista de } \\
\text { amenazas }\end{array}$ \\
\hline
\end{tabular}

F.O.D.A. DE ARGENTINA: Seguidamente desarrollaremos las fortalezas, oportunidades, debilidades y amenazas, siguiendo los análisis internos y externos correspondientes que según nuestro entender presenta Argentina:

SITUACION EXTERNA: Situación NO controlable o que no se encuentran bajo el dominio del estado nacional o de los estados provinciales que componen nuestro país:

- Oportunidades: Situaciones que tendría y/o deberían ser aprovechadas por la Argentina para contrarrestar las actividades del Narcotráfico

Postura internacional con relación a la lucha contra el narcotráfico: Actualmente la comunidad internacional ha tomado conciencia del peligro que representa para la seguridad internacional y de las naciones el avance de todas las actividades relacionadas directa o indirectamente con el 
Narcotráfico, por tal motivo Naciones Unidas, sus estados miembros, Organizaciones internacionales entre otros buscan constantemente co-ayudarse y cooperar mutuamente con la finalidad de combatir este flagelo que constantemente avanza a pasos agigantados.

La mutua cooperación entre los estados en la lucha contra las actividades del narcotráfico resulta ser un mecanismo importante para la formulación de políticas y acciones coordinadas entre las partes. Desde la conferencia de Shanghái en 1909 en donde se reunieron países como los Estados Unidos y países europeos para tratar el tráfico de opio, constituyo el primer intento de carácter multilateral para buscarle una solución al problema de las drogas. Como resultado de esta conferencia se aprobó la Convenzan Internacional del Opio en 1912, la que se considera como la base del actual sistema internacional de fiscalización de drogas.

La aprobación en 1912 de esta convención se tradujo en nuevos enfoques y lineamientos, las disposiciones de esta primera convención tenía como objetivo impedir el envío de cantidades indeseadas de estupefacientes a los países importadores, sin embargo pronto surgió que sin un sistema de información y vigilancia no sería posible verificar si los países exportadores cumplían o no con las disposiciones del tratado. Al mismo tiempo se percibía la debilidad en los controles de algunos países exportadores. Con esto Estados Unidos inaugura un sistema internacional de prohibición de drogas, basado en la idea de que para terminar con esta actividad criminal se debería suprimir la oferta y exterminar a los traficantes. "En virtud de una serie de tratados aprobados auspiciados por Naciones Unidas, los gobiernos han de fiscalizar la producción y la distribución de estupefacientes y de sustancias psicotrópicas, lucha contra el uso indebido y el tráfico ilícito de drogas, mantener los mecanismos administrativos necesarios e informar a los órganos internacionales a cerca de sus actividades" 86

Dentro de los acuerdos y tratados de cooperación en materia antidroga se tienen contemplados como objetivos, la erradicación y destrucción de plantíos, el compartimiento de información e inteligencia, labores y tareas conjunta entre las fuerzas de seguridad de los países el desmantelamiento de organizaciones internacionales y la investigación de delitos conexos como el lavado de activos y el tráfico de armas.

Con la finalidad de poder ilustrar de una mejor manera cuales son los tratados y convenios internacionales que hacen alusión al combate y cooperación para la lucha contra el narcotráfico, procederemos tan solo a enunciarlos sin hacer breve reseña de los mismos, ya que estaríamos ahondando en información que ya fue descripta o que no se considera necesario

\footnotetext{
${ }^{86} \mathrm{http}$ ://catarina.udlap.mx/u_dl_a/tales/documentos/lri/perez_s jip/capitulo3.pdf Tesis de Maestría
} 
explayarse, lo que sí es importante hacer una breve mención a los mismos para tenerlos en cuenta y tener siempre presente que la comunidad internacional tiende a contrarrestar esta actividad de tipo criminal transnacional:

* Convención Única de 1961 sobre Estupefacientes

* Convenio sobre sustancias psicotrópicas de 1971

* Convención contra el tráfico ilícito de estupefacientes y sustancias psicotrópicas

* Entre otros

Con esta enunciación pretendemos hacer mención a que la comunidad internacional está comprometida en la lucha contra el narcotráfico, por lo cual Argentina adhiere a esta tendencia mundial, así también lo hace saber la Organización de los Estados Americanos (OEA) en su informe de evaluación sobre el control de las drogas al que fue sometido nuestro país en el año 2014, en donde en su recomendación N N 27 hace mención a "REAFIRMAR EL PRINCIPIO DE COOPERACIÓN CONTENIDO EN LOS INSTRUMENTOS INTERNACIONALES PARA ENFRENTAR EL PROBLEMA MUNDIAL DE LAS DROGAS, A TRAVÉS DE ACCIONES QUE GARANTICEN SU CUMPLIMIENTO Y EFECTIVIDAD” lo cual fue ampliamente aprobado con el siguiente párrafo:

"Argentina reconoce los delitos tipificados de conformidad con el párrafo 1 del Artículo 3 de la Convención de las Naciones Unidas contra el Tráfico Ilícito de Estupefacientes y Sustancias Sicotrópicas de 1988 como casos de extradición y cuenta con normas que permiten la extradición de ciudadanos por la comisión de tales delitos. Igualmente, cuenta con mecanismos legales para someter a juicio a los individuos cuya extradición se ha denegado por los motivos previstos en el inciso a, del párrafo 2 del Artículo 4 de la Convención antes mencionada, así como en los casos de lavado de activos, reconociendo los delitos tipificados de conformidad con el Artículo 6 de la Convención de las Naciones Unidas contra la Delincuencia Organizada Transnacional de 2000, como casos de extradición. Las leyes u otras disposiciones legales en el país permiten brindar una amplia asistencia judicial recíproca a terceros Estados en las investigaciones, procesos y actuaciones judiciales referentes al tráfico ilícito de drogas y el lavado de activos; ha adoptado medidas para autorizar el decomiso del producto derivado del tráfico ilícito de drogas o de bienes cuyo valor equivalga a ese producto, así como de los materiales y equipos u otros instrumentos utilizados o destinados a ser utilizados en cualquier forma para la comisión de dicho delito. Asimismo, en el país se contempla el permitir a sus autoridades competentes la identificación, detección, y el embargo preventivo o incautación del producto, los bienes, los instrumentos o cualesquiera otros elementos utilizados o destinados a ser utilizados en cualquier forma para la Tesis de Maestría 
comisión del delito de tráfico ilícito drogas. Otras medidas dimanantes de la Convención de las Naciones Unidas contra el Tráfico Ilícito de Estupefacientes y Sustancias Sicotrópicas de 1988 han sido utilizadas por el país para fortalecer la cooperación internacional en el combate al tráfico ilícito de drogas. Adicionalmente, ha designado autoridades centrales con arreglo en los instrumentos internacionales relativos al tráfico ilícito de drogas, la fabricación y el tráfico ilícitos de armas de fuego y otros materiales relacionados, la delincuencia organizada transnacional y la asistencia mutua en materia penal. El país cuenta con leyes u otras disposiciones legales que permiten el uso de la entrega controlada de estupefacientes y sustancias psicotrópicas para identificar a las personas implicadas en el delito de tráfico ilícito de drogas.

Continuando con una premisa de que una de las mejores forma de combatir el narcotráfico es adherir a la idea de cooperación internacional, en una entrevista el Diputado del PRO Eduardo Amadeo explica que según su opinión buscar la "cooperación internacional” es una de las mejores maneras de combatir el flagelo del narcotráfico, por lo cual dejaremos el link para poder efectuar una lectura de dicha notifica periodística https://www.minutouno.com/notas/1469102-la-unica-manera-combatir-la-droga-es-cooperacioninternacional

Apoyo logístico y/o monetario que recibe Argentina por parte de organismos internacionales:

Es de público conocimiento que los países del primer mundo y las organizaciones internacionales prestan colaboración logística y monetaria en materia de lucha contra el narcotráfico a los diferentes países en el mudo, este detalle es importante más aun en un país como Argentina ubicado en América Latina donde sabemos que los recursos económicos para contrarrestar este accionar es bastante débil. Por lo cual Argentina en su caso debe aceptar la ayuda internacional que se le ofrece y en su caso también puede solicitar dicha ayuda, así también lo considero la actual titular del Ministerio de Seguridad de la Nación Patricia Bullrich.

\section{La Nación pedirá ayuda a EE. UU. para combatir el narcotráfico}

Según Patricia Bullrich, ministra de Seguridad, el Gobierno de Mauricio Macri va a pedir colaboración a los Estados Unidos para el combate del narcotráfico

El gobierno nacional, a través de la ministra de Seguridad, Patricia Bullrich, aseguró que la Argentina produce y vende drogas al exterior y que "es un problema muy grave" que "se ve en todos los pueblos", y reveló que se va a pedir ayuda a Estados Unidos para combatir el narcotráfico. 
"Argentina tiene una entrada de drogas muy fuerte, tiene fabricación, producción, laboratorios, cocinas, en todas las clases sociales ha aumentado el consumo. Hay mucho narcomenudeo, se ve en todos los pueblos. Es un problema muy grave”, aseveró la funcionaria.

En una entrevista con el diario El País de España, Bullrich explicó que el país "es punto de salida para Europa, también para algunos países asiáticos". Añadió que hay "altos niveles de exportación" de cocaína, y advirtió que "el nivel de alerta es amarilla”. Bullrich reiteró que el Gobierno de Mauricio Macri va a pedir colaboración a los Estados Unidos para el combate del narcotráfico, ya que "hasta ahora había una participación casi inexistente".

"Vamos a aumentarla (la asistencia), tanto la regional como internacional. Nos han planteado ayuda Francia, Italia, EE.UU., ya viajamos (hacia) allá. Estamos haciendo un trabajo fuerte con Paraguay, Bolivia, Uruguay, Chile, Brasil”, agregó. Sobre el rol de las fuerzas de seguridad, la ministra dijo que "hay policías y policías", y pese a que aseguró que fueron "muy maltratados", dijo que "hay que hacer cambios estructurales".

"Es como en la política: uno puede pensar que los que vienen más jóvenes son menos corruptos, pero si no hay cambio de paradigma la edad no importa", agregó. ${ }^{87}$

En igual sintonía Argentina continuo solicitando colaboración internacional para luchar contra esta tipología criminal, en este caso pidió la colaboración de Francia para tal fin:

Francia colaborará con Argentina en la lucha contra el narcotráfico: El presidente Hollande visita esta tarde a su par Mauricio Macri en Casa de Gobierno y firma una veintena de convenios. La prioridad: el tratado UE-Mercosur.

El presidente francés François Hollande, que hoy (miércoles 24) visitará Argentina, prometió ayuda de su país para combatir el narcotráfico y para reinsertarse en los mercados internacionales. Además, buscará un acuerdo entre el Mercosur y la Unión Europea, según dijo en una entrevista al diario Clarín, horas antes de aterrizar en Buenos Aires, donde esta tarde.

Hollande es el cuarto presidente de Francia que visita Argentina después del general Charles de Gaulle, Francois Mitterrand y Jacques Chirac. "Mi visita es la primera de un presidente francés desde 1997. Marca una nueva etapa de las relaciones entre Francia y Argentina. Se hace el mismo año en el que Argentina celebra el Bicentenario de su Independencia. Argentina es una República hermana de la República Francesa. Se inspiró en el espíritu de la Ilustración, que fue

\footnotetext{
${ }^{87}$ http://www.infocampo.com.ar/la-nacion-pedira-ayuda-a-ee-uu-para-combatir-el-narcotrafico/ Tesis de Maestría
} 
portado tan generosamente por el General José de San Martin. Pero mi visita está resueltamente volcada hacia el futuro", subrayó Hollade.

Respecto del narcotráfico, el presidente francés señaló que Macri "puede contar con nuestro apoyo. Ningún país está exento de este flagelo, que representa una amenaza mayor para la seguridad así como para la salud de las poblaciones". "Francia está dispuesta a responder a todo pedido de cooperación por parte de las autoridades argentinas, en todos los terrenos, desde el desmantelamiento de los tráficos, hasta la asfixia de los flujos financieros ilícitos, pasando por la formación de la policía y de las autoridades judiciales, o el aporte de material de vigilancia", subrayó.

Consultado por el tema de la deuda con los "holdouts", Hollande sostuvo que apoya "los esfuerzos de Argentina para lograr una solución de la cuestión central de la deuda, como lo hemos hecho siempre en el pasado. Es normal que Argentina, miembro del G20, pueda beneficiarse de condiciones de financiamiento razonables, equivalentes a las de otros países emergentes, con el fin de financiar sus inversiones". "Francia es el primer socio de Argentina en materia científica y tecnológica. Dos Premios Nobel científicos argentinos, Bernard Houssay en Medicina, y Luis Leloir en Química, son de origen francés. Ya a principios del siglo XIX, el científico francés Aimé Bonpland clasificaba en Argentina miles de especies vegetales, hasta entonces desconocidas en Europa, y lograba transformar en cultivable el famoso mate, que como todos saben (¡mejor que yo!), se convirtió en la bebida nacional argentina", recordó ${ }^{88}$.

- Amenazas: Situaciones que el estado nacional y/o los estados provinciales debemos reducir o neutralizar

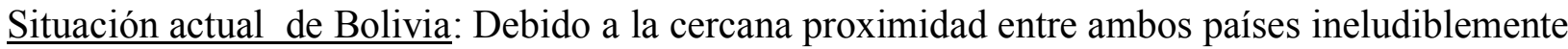
la situación por la cual atraviesa nuestro vecinos país, directa y/o indirectamente va a afectar nuestra situación con relación al narcotráfico, ya que actualmente Bolivia esta vivienda un aumento exponencial en todo lo relacionado con esta actividad criminal, anteriormente ya detallamos sobre ciertos puntos que influyen en esta actividad criminal en este país.

Es de importancia hacer constar que al parecer por estudios realizados previamente se está considerando a Bolivia con una país emergente en materia de narcotráfico, así lo detalla el siguiente recorte periodístico extraído de medios de comunicación:

\footnotetext{
${ }^{88}$ http://www.gacetamercantil.com/notas/95882/

Tesis de Maestría
} 
http://eju.tv/2011/11/onudc-bolivia-es-el-mayor-abastecedor-de-cocana-al-mercadosudamericano/

\section{ONUDC: "Bolivia es el mayor abastecedor de cocaína al mercado sudamericano”}

Tras la firma del Acuerdo entre Bolivia y EEUU, en el que se incorpora nuevamente la lucha conjunta contra el narcotráfico, el representante de la ONUDC en Bolivia habló del problema del narcotráfico.

"Bolivia es el mayor abastecedor de cocaína al mercado sudamericano"

DROGAS. Sudamérica se ha convertido en el nuevo mercado emergente del consumo de cocaína, al absorber el 20\% de toda la producción mundial de la droga.

Tras la firma del Acuerdo Marco entre Bolivia y Estados Unidos, en el que se incorpora nuevamente la lucha conjunta contra el narcotráfico, Página Siete conversó con César Guedes, representante de la Oficina de las Naciones Unidas contra las Drogas y el Delito, ONUDC.

Página Siete.- El informe de NNUU habla de que hay una extensión de 31.000 hectáreas en el país, mientras la erradicación fluctúa entre ocho y 10.000 hectáreas anuales, ¿cómo se explica esta dinámica?

La siembra y resiembra de la coca es dinámica. Mientras el Gobierno erradica en un lado, los cocaleros plantan en otro lado, y luego en algún tiempo vuelven al sitio erradicado. Pero si no hubiera erradicación hoy podríamos tener más de 40.000 hectareas.

Sin embargo, no es un tema sencillo de sumas y restas. Se debe hacer racionalización (erradicación), pero al mismo tiempo vigilar que no haya resiembra, que es difícil, pero no imposible.

En Perú se hacen grandes erradicaciones y aun así sus cultivos suben en 2 y 3\%. En Colombia, tras largos años de erradicación no se bajaba la extensión; hasta hace unos dos años, producto de la erradicación y la vigilancia de la resiembra, hoy se tienen fuertes disminuciones de 15 a $17 \%$ anuales.

Página Siete.- ¿Cuál es la mejor receta para contrarrestar esta perversa dinámica?

Lo primero que debe hacerse es mantener un clima pacífico e incrementar los esquemas de control social para evitar la resiembra. Y por supuesto las campañas de erradicación con las fuerzas del orden, en alianza con otros países pues nadie puede enfrentar esto solo. Tesis de Maestría 
Todos los países del área andina son participantes menores frente al narcotráfico. Nosotros hemos hecho un estudio y el negocio global de la cocaína son 85.000 millones de dólares al año, es decir, unas cuatro veces más que el PIB de Bolivia.

Página Siete.- ¿Cree usted que Brasil está en condiciones de reemplazar a la DEA, desde el punto de vista de recursos técnicos?

Si bien Brasil antes no prestaba mucha atención en su esquema geopolítico a los países andinos, hoy es diferente, tanto por buenas razones como las comerciales, como por los problemas como el narcotráfico y el crimen transnacional. Brasil es uno de los países más afectados por el narcotráfico y, particularmente, sabe que su frontera con Bolivia, de 3.400 kilómetros, es muy vulnerable y donde se produce un fuerte intercambio de ilícitos.

Brasil es un país pacífico y líder en la región, con un enfoque de igual a igual en su trato. Ahora bien, Brasil no tiene todas las capacidades técnicas de la DEA pero tiene muchas otras que serán de interés para paliar el problema entre los dos países.

La DEA ha trabajado en países que están muy lejos de las fronteras norteamericanas, como en Asia Central o Sudamérica, entre otros. Brasil, en cambio, tiene el problema al lado, entonces tienen que asumir el problema con los recursos que tiene. Por ello, en los últimos acuerdos antidrogas ha ofrecido los aviones no tripulados, servicios de inteligencia y coordinación de las autoridades de lucha antidrogas, para su propio beneficio.

Página Siete.- Hay la percepción de que Brasil busca más cuidar sus fronteras que cooperar en la lucha interna de Bolivia contra las drogas ilícitas. ¿Esto es así?

Brasil evita las intervenciones en otros países y tiene la credibilidad de la región. Y por ello no hará acciones directas sin el consenso del Gobierno boliviano y el tema de la coca es un tema sensible.

Ahora, en ese contexto, Brasil primero va a proteger sus fronteras. Y aqui hay razones más que suficientes como los eventos mundiales; el campeonato mundial de fútbol y las olimpiadas. Para ello se necesitan ciudades seguras, estabilidades y buena imagen, para lo cual están comenzando desde ahora. 
Ahora el origen del problema (drogas) está en Bolivia con los cultivos excedentarios y si Bolivia quiere ayuda en esta área debe ser mucho más amplio en su relación con Brasil, si quiere llegar a este nivel. Esto porque es un problema para Bolivia, pero también lo es más para Brasil.

Página Siete.- Bolivia era considerado un país productor, ¿cuál es la percepción ahora de la ONUDC, porque el tránsito parece que se ha incrementado?

Los países de tránsito son los que más sufren porque se encuentran bajo la presión de productores y consumidores. Están pagando con la propia sangre de sus pueblos y la inestabilidad de sus gobiernos, además de la enorme inversión en temas de seguridad. Entre estos países están Guatemala, Honduras, El Salvador, entre otros. Otro es México cuyas estructuras institucionales tambalean como efecto del narcotráfico.

En Bolivia no hay antecedentes violentos. Bolivia fue simplemente productor de hoja de coca, después se convirtió en productor de pasta base y más recientemente cocaína. Es decir, siempre productor y “exportador” de las sustancias ilícitas.

En los años recientes varios países sudamericanos se han convertido en el mercado consumidor emergente de drogas más importantes del mundo. Éstos son Brasil, Argentina y Chile. Así, la droga que puede venir de Colombia o Perú, con intención de capturar estos mercados, pasa por Bolivia.

Antes, la droga que transitaba por Bolivia tenía destino Europa, pero en el último tiempo, su destino son estos nuevos países consumidores, que ahora son clientes potenciales.

Página Siete.- ¿Qué cantidad de droga pasa por Bolivia?

Veamos algunos datos. El mayor nivel de incautaciones en el mundo de cocaína se hace en Sudamérica y llega a un $80 \%$ del total. Se calcula que hay unas mil toneladas de cocaína al año (dato 2009), de las que se secuestran unas 600 toneladas quedando unas 400 para el consumo, con un valor aproximado a los 85.000 millones de dólares.

De estas 400 toneladas, un 36\% es para el mercado norteamericano, que en los años 80 consumía un 90\% y ha bajado notablemente con la reducción del consumo e interdicción.

En los últimos años el consumo ha crecido en Europa que ahora consume un 30\% de esa droga y ahora Sudamérica con un $20 \%$. 
Página Siete.- El Gobierno dice que un 50\% de la droga que transita por Bolivia es peruana, ¿tienen ustedes ese dato?

Es una información del Gobierno. Nosotros no tenemos esos datos.

Bolivia es ahora un país de tránsito. Bolivia es la cabeza de playa para la droga de Colombia y Perú que va hacia el mercado sudamericano emergente. El esquema señala que la mayor parte de la droga colombiana va a Estados Unidos, un 20\% es para Europa y otros. De Perú, la mitad va al mercado estadounidense y la otra mitad a Europa y Sudamérica.

Sobre la droga Boliviana, se sabe que apenas el 1\% de la droga que sale del país va al mercado estadounidense. Bolivia es el neto abastecedor del mercado sudamericano y otra parte va a Europa. Ahora, sobre el consumo, aunque tenemos datos parciales, en general el consumo es menor que los otros países sudamericanos. Además, los mercados locales no son de interés del narcotráfico, que prefiere "exportar".

Pagina Siete.- ¿Como observa la ONUDC que en el tema interdicción en Bolivia se vea en algunas poblaciones comportamientos colectivos de protección a las actividades ilícitas del narcotráfico?

Nosotros también lo hemos vivido. Cuando hacemos el trabajo para nuestro reporte anual de monitoreo de cultivos y tras las imágenes satelitales hacemos sobrevuelos en zonas que no son muy claras y si esto no es suficiente vamos al trabajo de campo. Allí, en algunas poblaciones nuestros técnicos que van con otros técnicos del Gobierno, han sentido la amenaza y antes no había eso.

Nos preocupa porque ésta es una prueba clara de que el narcotráfico está comprando las voluntades de poblaciones grandes, está cercando su área de "trabajo" para tener una mayor protección.

NdE: El director de Página Siete, Raúl Peñaranda, no asistió a esta entrevista porque se encuentra en una visita de dos semanas a Israel.

"El narcotráfico en Bolivia está comprando las voluntades de poblaciones enteras y esta situación nos preocupa”. 
"El consumo de cocaína ha crecido en Europa al 30\%, mientras EEUU bajó del 90 al 36\% y sudamérica aparece con 20\%”.

"La dinámica del cultivo de coca muestra que mientras se erradica en un lado, se planta en otro".

"Sería bueno que se vean las nuevas propuestas que pudiera tener la DEA"

El representante de la ONUDC, César Guedes, se mostró respetuoso a la hora de comentar sobre la vetada presencia de la DEA en Bolivia y lo mencionó como un tema de decisión bilateral entre Bolivia y EEUU.

Sin embargo, al ser preguntado qué opinaba sobre un hipotético retorno de esa organización antidrogas de EEUU, en el marco del nuevo convenio bilateral manifestó: "Éste es un tema muy sensible y NNUU no puede recomendar que una institución venga o no a un país. Nosotros reconocemos las grandes capacidades que tiene la DEA y trabajamos en esquemas de cooperación con ellos en muchos lugares del mundo. La DEA tiene una gran capacidad técnica y logística para el combate al narcotráfico, pero ésa (el retorno) es una decisión soberana del Gobierno de Bolivia.

Ahora, sería bueno que se vean las nuevas propuestas que pudiera tener la DEA para trabajar en una nueva Bolivia, en un Estado plurinacional, y si esas propuestas se acercan a los intereses que tiene Bolivia”.

Guedes se animó a mencionar que nunca es bueno decir no. "Siempre es conveniente ver qué es lo que se ofrece para, sobre esa base, decir un sí o un no. Y creo que en esta nueva etapa de relaciones hay que mirar hacia adelante".

"La ONUDC ve el Acuerdo Marco Bolivia-EEUU como algo muy positivo, porque el combate a las drogas no se puede hacer en forma solitaria y Estados Unidos tiene una enorme experiencia y recursos en este campo", sostuvo

Finalmente, ante la consulta sobre la prolongada guerra a las drogas y la necesidad de explorar otras vías ante los reiterados fracasos, sostuvo: "No hay que ser fatalista ante esto. La guerra más cruenta, por ejemplo, es la que enfrento a China con el opio y la ganó. Es cuestión de voluntades y acciones concretas. Otra buena experiencia está en el sudeste asiático donde Tailandia, Laos y Camboya eran productores de heroína y ahora ya no lo son. 
La guerra contra las drogas requiere de una coordinación general y NNUU coopera con toda la estrategia que emana de los grandes acuerdos internacionales y las convenciones. Y esta guerra no ha fracasado, está llena de muchas batallas que se ganan y se pierden. La guerra hay que ganarla”, concluyó.

\section{HOJA DE VIDA}

Datos César Guedes, de nacionalidad peruana, trabaja hace 18 años en NNUU.

Estudios Profesional en ciencias administrativas, con maestría en relaciones internacionales en Holanda y liderazgo en Jordania.

Antecedente Antes de su arribo a Bolivia se desempeñó como director para América Latina y el Caribe de la ONUDC.

En los últimos años Sudamérica se hizo el gran consumidor de cocaína, en especial Brasil, Argentina y Chile.

La ONUDC ve el acuerdo Bolivia EEUU como muy positivo y con repercusión regional e internacional.

En esta nueva etapa de relaciones entre Bolivia y Estados Unidos, hay que mirar hacia adelante

Un detalle a tener en cuenta es la permeabilidad del límite fronterizo, si bien Argentina limita con otros países además de Bolivia, en este caso consideramos de importancia hacer alusión esta permeabilidad debido a la situación en la cual está inmerso el país vecino: LA FRONTERA ARGENTINA - BOLIVIANA:

La frontera con Bolivia presenta dificultades para el asentamiento permanente de la población debido a la altura, la escasez de agua, las grandes amplitudes térmicas diarias, etcéteras. Sólo hay dos lugares poblados con fácil comunicación entre ambos países. El primero, entre la ciudad de Salvador Mazza y Yacuiba y el segundo, en la quebrada de Humahuaca, donde se encuentra la localidad de La Quiaca que se enfrenta a Villazón en Bolivia.

Retomando el tema de las Fronteras y haciendo especial alusión al comercio internacional, vemos que el 70\% del comercio exterior argentino es marítimo y el resto, aéreo. Claro está que éstos son los porcentajes del comercio legítimo, pero que puede traer aparejadas relaciones delictivas como es tráfico de drogas, mercancías y otro tipo de productos. Debido a que los 
narcotraficantes y contrabandistas utilizan toda clase de estrategias legítimas o ilegales para cumplir con sus cometidos, ni el comercio marítimo ni el aéreo ni el terrestre son la excepción.

En el tema "droga" los delincuentes trafican llevando estas sustancias de un lado a otro con el fin de obtener divisas y los efectos que ésta causa ya todos los conocemos. En el mes de marzo del corriente año el programa televisivo "La Liga" nos ilustraba mediante un trabajo de investigación el trabajo que se realiza en la frontera entre Argentina y Bolivia con respecto al narcotráfico. Sabemos que dicha línea divisoria entre ambos países tiene 182 kilómetros.

Hoy hay varias formas de transportar la droga, una de las más comunes es dentro del estómago. Estas personas son conocidas como "mulas o capsuleros". La capacidad para transportar estas cápsulas de látex con cocaína varía según la contextura física de la persona. El promedio es de 70 a 80 cápsulas que representa entre 500 y 1500 pesos para quien la transporta, pero que en el bolsillo le quedan pesos 60 . Este es un tráfico de alto riesgo, puesto que si una cápsula se revienta se produce una muerte casi instantánea por sobre dosis.

Otra de las formas es el transporte de la hoja de coca. A éstos se los llama "chancheros o camellos" y son capaces de caminar varias horas y hasta cruzar el río sobre gomones con el fin de entregar la mercadería. El esfuerzo de éstos es remunerado de igual modo que los anteriores. El estado argentino ha destinado para línea fronteriza 2000 hombres con el fin de disminuir este delito, pero ellos se encuentran superados ya que la cárcel de Oran, lugar de destino de los detenidos, está llena al igual que el Hogar de Niños Nueva Esperanza, donde son internados los niños cuyos padres han caído detenidos. En este circuito de la droga podemos dar algunos indicadores. Mientras que en Yacante, un kilogramo de cocaína cuesta 1.000 dólares; en Salta, 6.000 y en Bueno Aires, 10.000 o 15.000 y en Europa, 50.000. Es evidente que para las personas de estas regiones el negocio no está en la droga sino en el transporte, que es en definitiva lo que le da de comer como ellos manifiestan "...si paso este cargamento algo gano y por lo menos como y si me meten preso también como y a mis hijos los llevan al hogar..." En este contexto los chicos son los únicos que pierden. A esto le sumamos los pequeños grandes enclaves de familias que se radican en las grandes urbes del país con el fin de colocar las sustancias. Cada familia puede llegar a introducir entre 50 y 60 kilogramos cada mes y medio.

Las políticas represivas, penales y públicas con respecto al narcotráfico o a la adicción a las drogas resultan ineficaces, pues quienes siembran a pesar de las políticas internacionales siguen sembrando y aumentan cada vez más la producción, es que este tipo de industrias después del tráfico de armas es la más rentable. Y como muchas veces ocurre se lo ve como una 
problemática relacionada contra la salud, y no contra la integridad de las naciones. El narcotráfico es un componente estructural en los estados, ya que tiene vinculaciones con la corrupción, lavado de dinero y el crimen organizado, es decir, con categorías políticas, jurídicas y económicas. Es nada menos que un actor internacional que comercia el $10 \%$ del mercado mundial. El Narcotráfico es una expresión multinacional de poder mediante el lavado de dinero, que supera ampliamente el presupuesto de la República Argentina y de Bolivia.

SITUACION INTERNA: Situación Controlable o que está dentro de nuestras posibilidades mantener su control

- $\quad$ Fortalezas: Las Tengo que aumentar/fomentar

Aplicación de la ley 23.737, Ley de des federalización de estupefaciente y ley de precursores quicos:

El correcto discernimiento y aplicación de las distintas normativas que rigen todo lo relacionado a las sustancias estupefacientes, es una buena manera de poder contrarrestar el problema del narcotráfico en nuestro país, por lo cual soy de opinión que más allá de que el problema de tráfico de drogas debe observado desde distintos puntos de vistas, efectuar una mirada judicial sobre las conductas criminales que rodean al narcotráfico es acertado.

Por tal motivo la aplicación de la ley nacional de estupefacientes 23.737 y sus modificaciones es totalmente acertado, considerando aún más acertado la regulación de un tema tan delicado como lo es "los precursores químicos" y el hecho de delegar a la justicia ordinaria de cada provincia la potestad de reprimir ciertas tipologías delictivas relacionadas a los estupefacientes, en tal sentido haremos mención en primera instancia a la DESFEDERALIZACION DE ESTUPEFACIENTES:

La ley $\mathrm{N}^{\mathrm{o}}$ 26.052, publicada en agosto de 2005, introdujo importantes cambios en la Ley de Estupefacientes ( $\left.\mathrm{N}^{\mathrm{o}} 23.737\right)$, vigente para todo el territorio nacional desde el octubre de 1989. Las modificaciones más importantes condicionaron la competencia material y territorial para ciertas figuras, fijando pautas para el destino de las multas, los beneficios económicos y los bienes decomisados.

En este apartado se presenta brevemente el marco normativo que, como se demostrará, modificó profundamente las atribuciones jurisdiccionales, el mapa de los actores relevantes y las prácticas institucionales en torno a la persecución penal de las conductas tipificadas en la Ley de Estupefacientes. En el segundo apartado se justificará la relevancia del estudio al presentar, entre Tesis de Maestría 
otros elementos, el volumen concreto de causas judiciales que migraron, a partir de la implementación de la Ley de Desfederalización en la Provincia de Buenos Aires desde la órbita de la Justicia Federal a la Justicia Provincial.

Primeramente se describirán brevemente los artículos de la Ley de Estupefacientes que la norma vino a modificar.

La ley $\mathrm{N}^{\mathrm{o}} 26.052$, en su artículo $1^{\circ}$, incorporó un último párrafo al artículo $5^{\circ}$ de la Ley de Estupefacientes, moderando las penas para aquellos delitos donde se entregue, suministre, aplique o facilite estupefacientes de modo ocasional y gratuito. El segundo artículo, importante a los efectos del presente estudio, modificó el texto del artículo 34 de la Ley de Estupefacientes por el siguiente:

Artículo 34: Los delitos previstos y penados por esta ley serán de competencia de la Justicia Federal en todo el país, excepto para aquellas provincias y la Ciudad Autónoma de Buenos Aires, que, mediante ley de adhesión, opten por asumir su competencia en las condiciones y con los alcances que se prevén a continuación:

1. Artículo $5^{\circ}$ incisos c) y e), cuando se comercie, entregue, suministre o facilite estupefacientes fraccionados en dosis destinadas directamente al consumidor.

2. Artículo $5^{0}$ penúltimo párrafo.

3. Artículo $5^{\circ}$ último párrafo.

\section{Artículo 14 .}

\section{Artículo 29․}

6. Artículos $204^{\circ}, 204^{\circ}$ bis, $204^{\circ}$ ter y $204^{\circ}$ quater del Código Penal."

Cabe destacar que previo a la sanción de esta norma, la Ley de Estupefacientes establecía que la justicia federal tenía competencia exclusiva para entender en la materia. Al momento de establecer la competencia de excepción, unificada para todo el territorio nacional, el legislador observó que los hechos vinculados al tráfico ilícito de estupefacientes presentan ramificaciones que trascienden las fronteras jurisdiccionales o nacionales y que frecuentemente tienen capacidad para vulnerar el tejido institucional o para afectar la salud pública.

En ese entonces se advertía - a nuestro entender certeramente - que atomizar la competencia entre las distintas jurisdicciones provinciales implicaba una arquitectura institucional ineficiente, que debilitaba y fragmentaba la presencia del estado afectando necesariamente la protección de 
los bienes jurídicos tutelados. Tras la modificación que introdujo la ley $\mathrm{N}^{\mathrm{o}} 26.052$ en agosto de 2005, el sistema dejó de ser unívocamente federal y se facultó a las provincias - mediante una ley de adhesión - para perseguir, juzgar y reprimir ciertos delitos tipificados en la Ley de Estupefacientes.

Así, de acuerdo con lo establecido por el art. 2 de la ley $\mathrm{N}^{\mathrm{o}} 26.052$, podrían investigarse a la órbita de la Justicia Provincial las investigaciones por los ilícitos previstos en los siguientes artículos de la ley $\mathrm{N}^{\mathrm{o}} 23.737$ :

Artículo $5^{\circ}$ penúltimo párrafo, "En el caso del inciso a), cuando por la escasa cantidad sembrada o cultivada y demás circunstancias, surja inequívocamente que ella está destinada a obtener estupefacientes para consumo personal, la pena será de un mes a dos años de prisión y serán aplicables los artículos 17,18 y $21 . "$

Artículo $5^{\circ}$ último párrafo, "En el caso del inciso e) del presente artículo, cuando la entrega, suministro o facilitación fuere ocasional y a título gratuito y por su escasa cantidad y demás circunstancias, surgiere inequívocamente que es para uso personal de quien lo recepta, la pena será de SEIS (6) meses a TRES (3) años de prisión y, si correspondiere, serán aplicables los artículos 17,18 y $21 . "$

Artículo $14^{\circ}$ "Será reprimido con prisión de uno a seis años y multa de trescientos a seis mil australes el que tuviere en su poder estupefacientes. La pena será de un mes a dos años de prisión cuando, por su escasa cantidad y demás circunstancias, sugiere inequívocamente que la tenencia es para uso personal."

Artículo 29․ "Será reprimido con prisión de seis meses a tres años el que falsificare recetas médicas, o a sabiendas las imprimiera con datos supuestos o con datos ciertos sin autorización del profesional responsable de la matrícula; quien las suscribiere sin facultad para hacerlo o quien las aceptare teniendo conocimiento de su ilegítima procedencia o irregularidad. En el caso que correspondiere se aplicará la accesoria de inhabilitación para ejercer el comercio por el doble de tiempo de la condena."

Artículo 204 ${ }^{\circ}$ CPN. "Será reprimido con prisión de SEIS (6) meses a TRES (3) años el que estando autorizado para la venta de sustancias medicinales, las suministrare en especie, calidad o cantidad no correspondiente a la receta médica, o diversa de la declarada o convenida, o excediendo las reglamentaciones para el reemplazo de sustancias medicinales, o sin la presentación y archivo de la receta de aquellos productos que, según las reglamentaciones 
vigentes, no pueden ser comercializados sin ese requisito.” (Y los Art 204 Bis, 204 ter, 204 quater que califican la figura primaria según determinados supuestos)

Sin embargo, en el caso del artículo $5^{\circ}$, incisos "c" y "e" de la ley 23.737 , la norma estableció una controvertida condición para la determinación de la competencia:

La infracción prevista en el Art. 5 inc. c) de la ley 23.737, que reprime a quien "comercie con estupefacientes o materias primas para su producción o fabricación o los tenga con fines de comercialización, o los distribuya, o dé en pago, o almacene o transporte;" pasará a la órbita de la Justicia Provincial siempre que se suponga el comercio de estupefacientes fraccionados en dosis destinadas directamente al consumidor.

El ilícito previsto en el Art. 5 inc. e) de la ley 23.737, que sanciona a quien "entregue, suministre, aplique o facilite a otro estupefacientes a título oneroso. Si lo fuese a título gratuito, se aplicará reclusión o prisión de tres a doce años y multa de tres mil a ciento veinte mil australes", será de competencia provincial cuando la entrega, el suministro o la facilitación de estupefacientes se verifique en dosis fraccionados para el consumo (omitiendo el supuesto de aplicación).

De la lectura de los antecedentes de las reuniones de la Comisión Legislativa y de los debates parlamentarios en los que se discutió el texto de la ley $\mathrm{N}^{0} 26.052$, ya se advertía una preocupación anticipada sobre la falta de claridad en el criterio que determinaría la competencia.

El eje de ese debate giraba en torno a fundados interrogantes sobre cómo interpretarían las fuerzas de seguridad, los jueces y los fiscales provinciales las condiciones que establece el nuevo artículo 34 para calificar los casos controvertidos.

La discusión no era de menor importancia, en tanto que la calificación de los hechos habilitaría la intervención de la justicia provincial. De este modo quedaría también condicionada la posibilidad de que los jueces y fiscales federales tomaran conocimiento de hechos que le permitieran avanzar hacia la determinación de ilícitos más complejos.

El eje crítico del debate planteaba que el supuesto de "comercialización de estupefacientes fraccionados en dosis destinadas directamente al consumidor" (Art. 5 inc. C, en el marco del Art. 34), abriría un abanico de zonas grises que, en la práctica, ubicaría a la jurisdicción provincial en mejores condiciones para determinar la competencia. En más de una oportunidad se señaló que ante la indefinición de la norma primaría la reproducción de las prácticas establecidas y los intereses locales. 
El legislador ya advertía que el empoderamiento de la jurisdicción provincial para determinar la competencia, podría derivar en el empoderamiento fáctico de las policías provinciales sobre el resto de los actores en juego. Dada su posición estratégica en el inicio de gran parte de las investigaciones que luego serían judicializadas, las policías provinciales tendrían - relativamente más posibilidades para incidir en la determinación de la competencia.

Por este motivo, por los posibles planteos de nulidad y por las dilaciones que podrían derivar en interminables contiendas se determinó incluir los siguientes artículos:

Artículo $3^{\circ}$ - Sin perjuicio de lo dispuesto en el artículo anterior, conocerá la Justicia Federal cuando la causa tuviere conexidad subjetiva con otra sustanciada en dicho fuero.

Artículo $4^{\circ}$ - En caso de duda sobre la competencia, prevalecerá la Justicia Federal. Sin embargo el texto de la ley no previó que los fiscales y jueces provinciales notifiquen a sus homónimos en el ámbito federal, especialmente en aquellos casos controvertidos, donde se supone la comercialización de grandes cantidades de estupefacientes fraccionados para el consumo.

Previsión que habría otorgado sentido práctico a la inclusión de los artículos $3^{\circ}$ y $4^{\circ}$.

De modo que allí donde al inicio de la investigación quedara determinada la competencia provincial, los jueces y fiscales federales no tendrían modo alguno de conocer en los hechos que -por su envergadura- corresponden a su competencia natural ${ }^{89}$.

\section{Reforma de la Ley de Estupefacientes 23.737, sobre precursores químicos}

En noviembre del año pasado (2016) se publicó en nuestro país la ley -penal- 27.302 que modifica algunos de los artículos y agrega otros nuevos a la tan conocida, cuestionada, llevada y traída Ley de Tenencia y Tráfico de Estupefacientes, "la" 23.737. El objeto principal de estos cambios legislativos es, entre otros no menos importantes, establecer o intensificar una serie de regulaciones y controles relativos a los precursores químicos, con mucha mayor precisión y detalle que en la anterior redacción de la ley. De modo que, necesariamente, nos enfrentamos a la primera pregunta, a la primera cuestión, la relativa a la materia regulada, al objeto de tanto quehacer legislativo: después de todo, ¿sabemos qué es un precursor químico? La palabra precursor suele calificar situaciones, hechos o sujetos que realizan una actividad pionera, sostienen ideas de avanzada, o, tratándose de hechos históricos, aquellos que marcaron un antes y un después, incluso, para gran parte de la humanidad. Desde ya que no definiríamos a esta persona o situación como un precursor..."químico", pero sí como adelantado, un fermento, un

\footnotetext{
${ }^{89} \mathrm{http}$ //fiscales.gob.ar/narcocriminalidad/wp-content/uploads/sites/6/2014/04/Informe_Ley_de_Desfederalizaci\%C3\%B3n.pdf
} Tesis de Maestría 
anuncio de lo que vendrá. Pretendemos, en estas reflexiones, aproximarnos al sentido específicamente jurídico del concepto precursor químico, que no se forma en el vacío sino que consulta los saberes aportados por las ciencias químicas, entre otras disciplinas, y especialmente, abreva en los conocimientos relativos a la función que cumplen las diferentes sustancias en los procesos de producción de estupefacientes y sicotrópicos.

\section{¿QUÉ ES UN PRECURSOR QUÍMICO?}

Una aproximación sencilla y hasta cierto punto, lega, nos permite afirmar que el precursor químico es una sustancia o compuesto químico simple necesario para obtener otra sustancia o compuesto químico diferente, más complejo; esto es posible por medio de la reacción química llamada síntesis. Durante el proceso de síntesis química se producen estos compuestos complejos a partir de otros simples que llamamos precursores químicos y sustancias químicas esenciales. La humanidad ha adquirido profundos conocimientos relativos a estos procesos y, por medio de la síntesis química y de su creciente control no sólo se sintetizaron sustancias conocidas en su estado natural -como el ácido acetilsalicílico, que está presente en las hojas del sauce- o a vitamina $\mathrm{C}$-ácido ascórbico, presente en algunos vegetales-, sino que también se obtuvieron y se obtienen, año a año, nuevas sustancias químicas, nuevos productos que no existen en la naturaleza, los cuales tienen una enorme importancia económica y usos más que corrientes: los adhesivos y tinturas, los plásticos, el acero, son apenas algunos ejemplos. Inmediatamente y sin más, podemos comprender la relevancia de estos conocimientos, del desarrollo de las ciencias químicas y sus aplicaciones en la fabricación de plásticos y otros derivados del petróleo, de fármacos de uso humano y veterinario, tinturas, pinturas y colorantes industriales, fertilizantes, combustibles, en la industria textil, la agricultura y prácticamente, en toda actividad productiva. Los así llamados precursores, tanto en la terminología de las ciencias químicas como en el lenguaje jurídico del derecho local e internacional, son caracterizados, en ambas disciplinas -y en los textos legales- por su función, en razón de su utilización: la de ser sustancias necesarias para obtener o elaborar "otras" -en el caso, un estupefaciente, un preparado o un sicotrópico-. Así surge claramente del Artículo 12 de la Convención de las Naciones Unidas contra el Tráfico Ilícito de Estupefacientes y Sicotrópicos de 1988 y su Anexo, los Cuadros I y II, conocidos como la Lista Roja ("Lista de Precursores y sustancias químicas utilizados frecuentemente en la fabricación ilícita de estupefacientes y sustancias sicotrópicas sometidos a fiscalización internacional"). En efecto, el nombre del Artículo 12, focal en la Convención de 1988, es "Sustancias que se utilizan con frecuencia en la fabricación ilícita de estupefacientes o sustancias sicotrópicas", verdadera definición jurídica, por su función y la finalidad de su empleo, de los 
conceptos precursor y sustancias químicas esenciales. Por supuesto, establece que "las Partes adoptarán las medidas que estimen adecuadas -art. 12.1- para evitar la desviación de las sustancias, utilizadas en la fabricación ilícita de estupefacientes o sustancias sicotrópicas"90

Fortalecimiento Institucional: Efectuar un apoyo y fortalecimiento de las instituciones que de una forma $\mathrm{u}$ otra ayudan al combate del narcotráfico es una actividad importante para contrarrestar esta problemática, oportunamente la Organización de los Estados Americanos (OEA) en su informe del control de las drogas, hizo hincapié en la acertada actividad en relación a esta temática llevada a cabo por nuestro país: ESTABLECER Y/O FORTALECER LAS AUTORIDADES NACIONALES DE DROGAS, COLOCÁNDOLAS A UN ALTO NIVEL POLÍTICO, CON LA MISIÓN DE COORDINAR LA PLANIFICACIÓN Y APLICACIÓN EFECTIVA DE LAS POLÍTICAS NACIONALES SOBRE DROGAS

Argentina cuenta con una autoridad nacional de drogas, la Secretaría de Programación para la Prevención de la Drogadicción y la Lucha contra el Narcotráfico (SEDRONAR), la cual funciona vinculada directamente a la Presidencia de la Nación Argentina y cuenta con un fundamento legal y un presupuesto. La autoridad nacional coordina las áreas de reducción de la demanda, reducción de la oferta, medidas de control, observatorio de drogas, cooperación internacional y evaluación de programas. El país cuenta con un mecanismo de coordinación para llevar a cabo la planificación y ejecución efectivas de las políticas nacionales sobre drogas.

DISEÑAR, IMPLEMENTAR, FORTALECER Y ACTUALIZAR LAS ESTRATEGIAS Y POLÍTICAS NACIONALES SOBRE DROGAS BASADAS EN LA EVIDENCIA

Argentina cuenta con el Plan Federal de Prevención Integral de la Drogodependencia y de Control del Tráfico Ilícito de Drogas 2012-2017, que incluye las áreas de reducción de la demanda, reducción de la oferta, medidas de control y cooperación internacional. Los actores relevantes de las áreas prioritarias participan en el diseño, redacción y ejecución del Plan Federal, el cual cuenta con un marco de seguimiento y evaluación. Argentina no ha realizado actividades para actualizar políticas, planes y programas, de acuerdo con la evaluación del Plan Federal.

ESTABLECER Y/O FORTALECER LOS OBSERVATORIOS NACIONALES DE DROGAS U OFICINAS TÉCNICAS SIMILARES PARA EL DESARROLLO DE SISTEMAS NACIONALES DE INFORMACIÓN SOBRE DROGAS Y EL FOMENTO DE LA INVESTIGACIÓN CIENTÍFICA EN ESA MATERIA

\footnotetext{
${ }^{90} \mathrm{http}: / /$ www.pensamientopenal.com.ar/system/files/2017/02/doctrina44847.pdf Tesis de Maestría
} 
Argentina cuenta con el Observatorio de Drogas. El país cuenta con dos estudios prioritarios en reducción de la demanda de drogas y con toda la información prioritaria sobre la reducción de la oferta de drogas. Argentina realizó un estudio sobre el costo económico y social de las drogas. El país divulga información sobre la demanda y oferta de drogas a las partes interesadas. Argentina no ha realizado estudios sobre acceso a los registros de pacientes en centros de tratamiento ${ }^{91}$.

- Debilidades: Situaciones que tengo que disminuir/erradicar

Reducción de la Demanda: Una situación que Argentina debe hacer hincapié en post de luchar contra el narcotráfico es la reducción de la demanda de sustancias o la reducción del consumo de la misma, para lo cual deberá hacer un estudio a fondo en torno a esta situación y diagramar estrategias para poder logra dicho objetivo:

\section{DESARROLLAR E IMPLEMENTAR POLÍTICAS, PLANES Y/O PROGRAMAS INTEGRALES DE REDUCCIÓN DE LA DEMANDA}

Argentina cuenta con programas integrales en reducción de la demanda que incluyen las áreas de prevención, intervención temprana, tratamiento y rehabilitación, reinserción social y servicios relacionados al apoyo en la recuperación. Dichos programas han sido diseñados utilizando la evidencia disponible en la materia. La perspectiva de género se incluye en su diseño, implementación y evaluación. Todos los programas están basados en datos de prevalencia relevantes y tendencias del consumo de drogas recopiladas por medio de encuestas. El monitoreo de los programas se aplica en la prevención universal, tratamiento, rehabilitación, reinserción social y servicios relacionados al apoyo en la recuperación. Asimismo, la evaluación se aplica a la prevención universal, al tratamiento y rehabilitación, y a la reinserción social. La actualización de los programas se basa en los resultados de las evaluaciones y se adoptó un abordaje multisectorial con la participación de diversos sectores de la población. Argentina no evalúa la implementación de los programas sobre los servicios relacionados al apoyo en la recuperación. No evalúa ni monitorea los programas de prevención selectiva e indicada, ni de intervención temprana.

DISEÑAR E IMPLEMENTAR UN SISTEMA INTEGRAL DE PROGRAMAS DE PREVENCIÓN UNIVERSAL, SELECTIVA E INDICADA BASADOS EN LA EVIDENCIA, CON OBJETIVOS MEDIBLES, DIRIGIDOS A LOS DISTINTOS GRUPOS POBLACIONALES, INCLUYENDO POBLACIONES EN RIESGO

\footnotetext{
${ }^{91}$ http://www.cicad.oas.org/mem/reports/6/Full_Eval/Argentina\%20-\%20Sexta\%20Ronda\%20de\%20Evaluacion $\% 20$ $\% 20$ ESP.pdf

Tesis de Maestría
} 
Argentina cuenta con programas de prevención universal, selectiva e indicada que abordan el consumo de drogas. Los programas de prevención selectiva e indicada varían de acuerdo con los factores de riesgo y están dirigidos a grupos específicos de la población. El país cuenta con un sistema integral de prevención

FORTALECER LAS RELACIONES GUBERNAMENTALES CON INSTITUCIONES ACADÉMICAS, DE INVESTIGACIÓN Y ORGANIZACIONES NO GUBERNAMENTALES (ONGs) ESPECIALIZADAS, A FIN DE GENERAR EVIDENCIA SOBRE LA DEMANDA DE DROGAS.

Argentina cuenta con una autoridad nacional de drogas que mantiene relaciones de cooperación con instituciones académicas y de investigación, organizaciones de la sociedad civil e instituciones públicas pertinentes que abordan temas relacionados con la reducción de la demanda de drogas. La información producida por las instituciones académicas y de investigación y las organizaciones de la sociedad civil es utilizada en las políticas, planes y programas de reducción de la demanda. El país respalda la capacidad de las instituciones académicas y de investigación y de la sociedad civil, intercambiando información y generando reportes basados en evidencia sobre temas relacionados con el abuso de drogas ${ }^{92}$.

$\underline{\text { Contrarrestar la presencia de organizaciones o carteles criminales que se dedican al narcotráfico }}$ en nuestro país:

Debido al avance de la criminalidad organizada en su faceta del narcotráfico en nuestro, se ha visto incrementada la presencia de representas de la criminalidad organizada extrajera en nuestro país, así lo demuestran las publicaciones efectuadas por distintos medios de comunicación:

\section{http://eju.tv/2014/04/la-repblica-de-la-cocana-invade-el-norte-argentino/}

\section{La "República de la Cocaína" invade el norte argentino}

Informes de prensa desde la provincia argentina de Salta advierten del ingreso a gran escala en el norte del vecino país de "filas de camiones semirremolques provenientes de Bolivia"

\footnotetext{
${ }^{92}$ http://www.cicad.oas.org/mem/reports/6/Full_Eval/Argentina\%20-\%20Sexta\%20Ronda\%20de\%20Evaluacion $\% 20$ $\%$ 20ESP.pdf

Tesis de Maestría
} 
Se trata de vehículos que transportan ingentes cantidades de cocaína, mayormente fabricada con la materia prima que cultivan los sindicatos cocaleros del Chapare que preside Evo Morales (recordemos que según la ONU, el 95\% de la coca de esa región va a parar fuera de los mercados legales que abastecen la práctica tradicional del "acullico", es decir, al narcotráfico).

La información generada en Argentina habla incluso de caminos de tierra abiertos por los narcos, fuera de la vigilancia policial.

Sumemos a esto el dato divulgado meses atrás por un juez de ese país, sobre laboratorios montados en el norte argentino para la

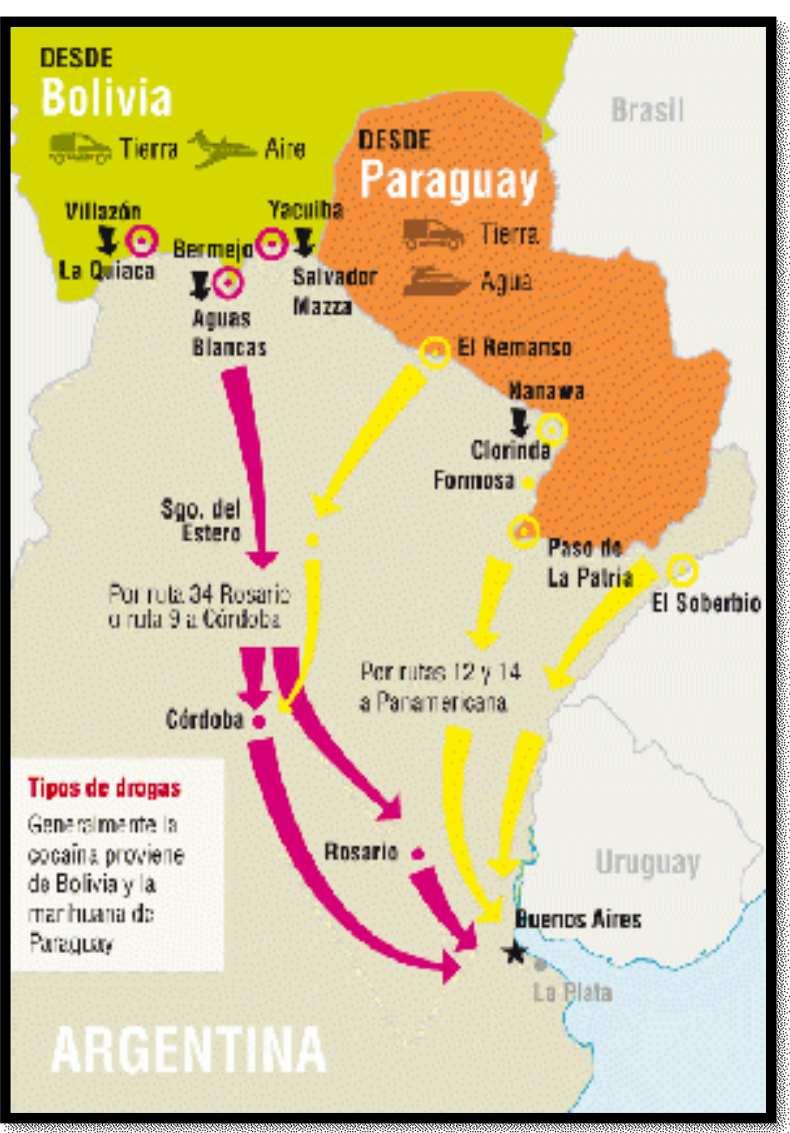
producción de cocaína, abastecidos con hoja de coca boliviana (chapareña).

Tenemos entonces que la "República de la Cocaína", como llamó la revista Veja a un entramado de narco-poder de gran influencia en altas esferas bolivianas, no solo inunda las favelas brasileñas, sino que ahora parece enseñorearse también de los vecinos del sur.

\section{http://eju.tv/2011/04/90-de-la-hoja-de-coca-va-a-la-droga/}

\section{$90 \%$ de la hoja de coca va a la droga}

Ernesto Justiniano afirma que entre el 2006 al 2009 un 95\% de la coca se fue al narcotráfico. El ex zar antidroga y un escritor hablaron con los universitarios sobre "Las consecuencias jurídicas, políticas y sociales del narcotráfico en Bolivia”.

El negocio de la cocaína se extiende: Incautan $213 \mathrm{Kg}$ de droga en Basilio y en Argentina caen 5 $\underline{\text { bolivianos con } 93 \mathrm{Kg} \text { de cocaína }}$

El Día

$90 \%$ de la coca va a la droga 
Las cifras del narcotráfico. Un ex zar antidroga y un escritor sobre el tema hablaron con los universitarios sobre las consecuencias jurídicas.

Un 90\% de la producción de la coca en el Chapare va a la droga. Esa fue la cifra que alarmó a los universitarios de la Gabriel René Moreno, que debatieron junto al ex zar antidroga, Ernesto Justiniano, y el escritor Emilio Martínez, sobre el narcotráfico en Bolivia.

Los números salieron del informe anual que entrega la Organización de Naciones Unidas (ONU), donde señala que entre el 2006 al 2009 la producción de coca, en esta región fue de 100 mil toneladas, de esta cifra, cinco mil solamente habían ingresado a mercados legales, por tanto un $95 \%$ se fue al narcotráfico, dijo Justiniano.

Los asistentes a la conferencia sobre "Las consecuencias jurídicas, políticas y sociales del narcotráfico en Bolivia”, también recibieron las cifras a nivel nacional, donde se explica que la producción fue de 207.684 toneladas métricas de coca y que solamente 69.091 ingresaron a mercados legales, convirtiéndose en un $67 \%$ de coca que fue desviada al mercado de la droga.

"La política de cocaína cero fracasó por un desconocimiento, o ha propósito pienso yo, o por lo menos las cifras lo demuestran. En vez de un Plan Cocaína Cero vamos a estar en el Plan 100\% en este año o en el próximo", advirtió el ex zar antidroga...

\section{http://eju.tv/2012/10/la-felcn-identifica-cuatro-nuevas-rutas-del-narcotrfico/}

\section{La FELCN identifica cuatro nuevas rutas del narcotráfico}

De Bolivia se dirigen a Brasil, Argentina y Paraguay. Las poblaciones del norte de Santa Cruz son puntos de almacenaje y traslado.

FELCN identifica cuatro nuevas rutas del narcotráfico.

Cuatro rutas para exportar ilegalmente cocaína fueron identificadas en Santa Cruz, en donde operan al menos 10 organizaciones de narcotraficantes, compuestas por bolivianos, colombianos, brasileños y paraguayos, señala un informe de la Fuerza Especial de Lucha Contra el Narcotráfico (FELCN).

Desde que sucedió un tiroteo, en Warnes, el pasado 5 de octubre, el trabajo del grupo especial de Inteligencia, de la FELCN, se ha duplicado, refirió un oficial de la Policía, cuya identidad se mantiene en reserva. 
De acuerdo con el reporte, las poblaciones de Ichilo, Yapacaní, Montero y Warnes, que forman parte del norte integrado de Santa Cruz, son las áreas en donde se acopia la droga y se la prepara para su traslado hacía el Brasil, Argentina y Paraguay.

El efectivo de la Policía explicó que cada cargamento es trasladado por vía área hasta los puntos fronterizos, en donde hay más de una centena de sendas por donde se lleva la droga al exterior del país.

Desde Ichilo, la droga se transporta con rumbo a Argentina y Paraguay, desde Yapacaní al sur de la frontera de Bolivia con el Brasil, y de Warnes hacia el norte brasileño que es dominado por el Primer Comando de la Capital (PCC).

Las VÍAS DE TRANSITO. El informe señala que hasta hace unos meses, estos corredores estaban ubicados en La Paz, Oruro, Potosí, Pando, Beni y Santa Cruz, en donde procesaban y después trasladaban la droga a los puntos fronterizos. Pero ahora estos sectores son áreas de tránsito para la droga peruana.

Por la ubicación y el extenso territorio del norte integrado cruceño, los traficantes instalan fábricas móviles de cristalización.

La cocaína es transportada por vía área desde pistas clandestinas.

2,7 millones de libras de hoja de coca para narcos fue decomizada por el Digcoín en el 2012.

http://eju.tv/2015/09/narcos-entrenan-en-argentina/

\section{"Narcos entrenan en Argentina"}

Un experto mexicano asegura que los carteles se instalaron en el país

\section{ENTREVISTA A MAYOLO MEDINA LINARES}

Fue director de inteligencia de la Procuraduría y secretario de Seguridad Pública. Dice que "Argentina es la cocina de drogas de Latinoamérica".

Debate. Medina Linares participó de un encuentro internacional sobre combate del narcotráfico. Habló de los laboratorios argentinos. | Foto: Sanders

Mayolo Medina Linares conoce de cerca la peor cara del narcotráfico de la región. Fue secretario del Sistema Nacional de Seguridad Pública de México y director de Inteligencia de la Procuraduría, y se especializa en el combate contra el crimen organizado de ese país. Luego de 
disertar en el segundo simposio del Observatorio de Prevención del Narcotráfico (Oprenar) en la UADE, un evento organizado por pedido del papa Francisco, charló con PERFIL sobre la problemática en Argentina.

Propone "la despenalización gradual". "Un narcotráficante es un operador. Mientras que no entendamos que el consumo se da en este contexto de negocio y demanda en el mercado, no vamos a poder triunfar", aconseja. Las drogas le causan muerte a 200 mil personas anualmente.

— ¿Cuál es la situación en nuestro país?

-El narcotráfico en la parte norte de Argentina es casi evidente por las cercanías con las fronteras de países productores. Argentina no tiene productos base, pero sí son transformadores de los mismos, por esa razón se encuentran laboratorios. Es lo que sucede en México. Todas las drogas que llamamos estimulantes tipo anfetamínicos... los precursores vienen de Asia, principalmente, y de la India y entran por dos puertos importantes de México en el Pacífico. Esa es toda la franja donde hoy encontramos a los Caballeros Templarios y a Jalisco Nueva Generación. Una vez que llegan ahí, se transforma. Los cocineros de anfetaminas están en todo Tijuana. Argentina es, además, la salida hacia Europa.

-En 2009, Argentina se vio conmocionada por un triple crimen que puso de manifiesto la efedrina vinculada al narcotráfico internacional y la ruta hacia México.

-Un hecho que hay que reconocer es que existe una mutación por los estimulantes en el mundo. Es decir, la cocaína que en su momento tuvo un auge importarte, sobre todo en el año 2000, hoy tiene un consumo estable. Lo que hoy se ha disparado en una medida exponencial son estos estimulantes de tipo anfetamínico. Los líderes de los grandes carteles no se arriesgan a salir del país, porque pueden ser atrapados, pero sí creo que pueden tener operadores en Argentina.

—CCómo es la situación en México?

- Lo más grave que vive hoy México es la violencia. En la última década aumentaron los consumidores $25 \%$ y los asesinatos violentos vinculados al crimen organizado son superiores a los 10 mil. Los daños colaterales asociados a la violencia y a la narcocultura que percibe como héroes a los narcos no se ven en Washington.

—Pero sí se ven en Argentina... 
-Por eso necesitamos, los países de América Latina, no formar un bloque, sino levantar la voz. No vamos a cambiar los patrones de consumo. Ya hemos fracasado. La política de prohibición y punitiva ha fracasado.

— ¿La existencia de bandas que pelean por el territorio y las figuras de narcos heroicos son síntomas que nos pueden llevar a ser México?

— Si Argentina no pone atención, va hacia ese lugar. Tenemos que dar paso a corrientes alternas de pensamiento. Ese camino por el que está en trayectoria la Argentina va a llegar al mismo caso de México. Va en ese camino. No hay evidencias que me digan que no va a suceder. Sí veo que existen esfuerzos, pero son aislados porque que el narcotráfico sea un negocio prohibido genera ganancias, pero junto a eso, produce violencia, y va en aumento. Cuando en México comenzamos a tener las primeras manifestaciones de esta violencia impensable y cruel, eran aisladas, pero ahora ya es una estructura cotidiana. Ya no nos sacude. "Ah, encontraron dos cabezas", decimos como si nada. Nos acostumbramos. Y no es sólo que los veamos como héroes, sino que han generado respaldo social. Antes, en México, decíamos que éramos los "burros" de Colombia, porque transportábamos cocaína a Estados Unidos, no la producíamos. Pero luego, los mexicanos se dieron cuenta de que era un negocio muy bueno y ahí empezó la violencia. La guerra contra el narcotráfico está perdida y es una pesadilla silenciada.

La cifra: 400 mil millones de dólares anuales es lo que mueve el narcotráfico, según el experto.

— ¿Tiene información sobre la presencia de carteles mexicanos en Argentina?

- Sí. Hubo una manifestación en alguno de los órganos de mi país, con el grupo de analistas con los que me reúno, de que había ya presencia de mexicanos en este país.

— ¿Están en actividad?

-Sí. Específicamente no sabemos qué cartel, sabemos que viene del lado del Pacífico porque es más para la producción, no para generar violencia, sino para seguir ganando dinero. Puede existir una especie de apoyo logístico en la frontera norte de Argentina, como una base que funciona para la transmisión de conocimiento, cómo producir estas drogas sintéticas, de control.

-En Argentina existe un debate por la presencia de paco y pasta base. Entonces, ¿es un país productor o de tránsito?

- Hoja de coca no se produce en Argentina, pero sí se transforma. Son, entonces, los cocineros de cocaína de Latinoamérica. México es cocinero de anfetaminas. La droga no pasaría por Tesis de Maestría 
Argentina si no saliera para Europa. En mi país hay capillas dedicadas a narcotraficantes, la gente va, se persigna y pide que tenga suerte para matar a otros. No cerremos los ojos, esto está en nuestra sociedad y no va a desaparecer.

\section{F.O.D.A. DE BOLIVIA:}

SITUACION EXTERNA: Situación NO controlable

- Oportunidades: las tengo que aprovechar

Postura internacional con relación a la lucha contra el narcotráfico: Este ítems es similar al ya descripto anteriormente en el análisis de Argentina, ya que la comunidad internacional y los organismos internacionales constantemente buscan erradicar y contrarrestar las actividad relacionadas al narcotráficos, en ambos casos hacemos alusión por ejemplo a Estados Unidos, Unión Europea entre otros ya que estos mercados son los elegidos al momento de comercializar las sustancias que se producen y/o transitan por suelo sudamericano.

Cooperación internacional a Bolivia: En el caso específico de Bolivia, este país recibe un tratamiento especial por parte de la comunidad internacional, ya que al ser un país productor de estupefacientes, varios de los mismos lo ven como una amenaza, siendo que su producción es exportada hacia los grandes mercados del mundo e incluso a países limítrofes en donde el consumo de sustancias está aumentando.

Esta colaboración se manifiesta en distintas formas, ya sea en el aporte económico, capacitación de fuerzas de seguridad, convenios de trabajo bilateral entre otros casos:

\section{http://eju.tv/2011/12/brasil-ofrece-informacin-del-narcotrfico-en-las-fronteras/}

\section{Brasil ofrece información del narcotráfico en las fronteras}

Lucha. Son datos de operativos de vehículos aéreos no tripulados. Los VANT permitirán interceptar las violaciones al espacio aéreo de narcotraficantes y contrabandistas.

La presidenta brasileña, Dilma Rousseff, señaló a su homólogo Evo Morales, que su país está dispuesto a proporcionar la información recabada por los vehículos aéreos no tripulados (VANT) en las fronteras con Bolivia y otros países para una lucha más efectiva contra el narcotráfico.

Así lo aseveró ayer el ministro de Defensa, Rubén Saavedra, en entrevista con los medios estatales, quien puntualizó que el ofrecimiento fue realizado en la charla reservada del viernes que tuvieron los dos mandatarios, antes de la cumbre que dio nacimiento a la Comunidad de Estados Latinoamericanos y Caribeños (Celac), en Venezuela.

Saavedra puntualizó que sobre el tema antidrogas, ambos líderes hicieron hincapié en el rubro de la cooperación. "Se mencionó por parte de la Jefa del Estado que Brasil estaba dispuesto a proporcionar información a las autoridades bolivianas para luchar más eficazmente contra el narcotráfico", comentó el titular de Defensa.

Autorización. Bolivia y Brasil firmaron este año un acuerdo por el cual el país vecino se comprometió a controlar por aire los puntos fronterizos, con la ayuda de los aviones VANT. El viceministro de Defensa 
Social, Felipe Cáceres, señaló que las autoridades brasileñas implementarian similares tareas en los límites con Perú y Paraguay.

Bolpebra, Corumbá, Puerto Suárez, Cáceres-San Matías, Guajará-Mirim-Guayaramerín y BrasilEpitaciolandia-Cobija, son los sitios donde se llevarán a cabo los operativos que debian iniciar en septiembre; pero, según ANF, Cáceres dijo a fines de octubre que todo estaba retrasado por falta de autorización de los senados de Brasil y Bolivia.

Sin embargo, Saavedra manifestó ayer que "Brasil está usando vehículos aéreos no tripulados VANT en (la) frontera con Bolivia y otros paises. Y se quedó (con la presidenta Rousseff) en que la información sea proporcionada a las autoridades bolivianas, en el marco de lucha contra el narcotráfico".

Los VANT permitirán interceptar las violaciones al espacio aéreo de narcotraficantes y contrabandistas.

EEUU. Ante la especulación de que Brasil estaría molesto porque todavía no se firmaron los memorandos de entendimiento entre Bolivia, Estados Unidos y este país para controlar los cultivos excedentarios de coca bolivianos, el Ministro de Defensa manifestó que el presidente Morales le subrayó a Rousseff que Bolivia ya habia firmado un acuerdo marco (con EEUU) para luchar en este tema".

Confirmó que oficiales bolivianos participan como observadores de la operación militar brasileña Ágata 3, del cual también son parte Perú y Paraguay. Este plan se ejecuta desde el 24 de noviembre y tiene la misión de luchar contra el narcotráfico y otros ilícitos en las fronteras, "Se nos notificó de ello", remarcó Saavedra.

En cuanto a otro tema fronterizo, el viceministro de Defensa, José Luis Prudencio, y su par peruano, Pablo Aranibar, se reunirán hoy y mañana en el marco del Mecanismo de Consulta y Coordinación "2+2", que acordará una metodología para medir gastos militares y reglamentará la creación de una Comisión Binacional de Fronteras, indicó la agencia EFE.

Droga en patinetas

Ocho kilos y 27 gramos de cocaína hábilmente camuflados en tres patinetas con destino España, fueron descubiertos en el aeropuerto de El Alto por los agentes de la Fuerza Especial de Lucha Contra el Narcotráfico (FELCN), informó ABI.

Brasil confirma apoyo antidroga

Aviones no tripulados coadyuvarán.

Por Gabriela Imaña - La Prensa - 5/12/2011

La Paz. El Gobierno de Brasil confirmó apoyo de aviones no tripulados (VAN) para la efectiva lucha contra del tráfico ilícito de cocaína que libra Bolivia, anunció el domingo el ministro de Defensa, Rubén Saavedra.

"En la reunión bilateral, la presidenta de Brasil y el jefe de Estado, Evo Morales, hablaron de la cooperación en la lucha contra el narcotráfico, proporcionando información a Bolivia para una eficaz lucha antidroga, una fuerte campaña”.

http://eju.tv/2014/10/bolivia-el-nuevo-epicentro-del-narcotrafico-en-suramerica/

\section{Bolivia: el nuevo epicentro del narcotráfico en Suramérica}

Tesis de Maestría 
“...La reelección de Morales significa que es poco probable que el estado actual de las relaciones con Estados Unidos cambie. Actualmente no hay presencia de la Agencia Antidrogas de Estados Unidos (DEA, por sus siglas en inglés), y desde mediados de 2013 la Oficina para Asuntos Narcóticos Internacionales y Aplicación de la Ley (INL, por sus siglas en inglés) y la Agencia de los Estados Unidos para el Desarrollo Internacional (USAID, por sus siglas en inglés) han dejado el país. Si bien Bolivia ahora recibe apoyo antinarcótico de la Unión Europea y Brasil, ninguno de ellos cuenta con la experiencia, los recursos o los datos para comenzar a llenar el vacío dejado en la inteligencia estratégica, alguna vez suministrada por Estados Unidos..."

http://eju.tv/2015/09/onu-plantea-las-escuchas-telefonicas-contra-narcos/

\section{ONU plantea las escuchas telefónicas contra narcos}

\section{EL DEBER DIGITAL, LA PAZ}

El Gobierno boliviano alista dos normas para sustituir la vigente Ley 1008. Se reiteró la sugerencia de rehabilitar a traficantes al menudeo y luchar contra las grandes redes

La Organización de las Naciones Unidas Contra las Drogas y el Delito (Unodc, por sus siglas en inglés) plantea que Bolivia incorpore las escuchas telefónicas como método para luchar contra las grandes redes de narcotraficantes.

"En lugar de luchar contra los eslabones más débiles, se debe combatir mayores herramientas, herramientas del siglo XXI, como lo es por ejemplo la posibilidad de implementar las escuchas telefónicas, la posibilidad de profundizar las investigaciones", señaló en la víspera el representante de ese organismo en el país, Antonino de Leo.

La propuesta surge como anticipo a los dos proyectos de norma que el Gobierno elabora para sustituir la vigente Ley 1008. Además ratificó la necesidad de combatir el tráfico de sustancias ilícitas a gran escala y no así contra los microtraficantes.

"Una nueva Ley de Sustancias Controladas prioritariamente contra las grandes redes del tráfico de drogas, en lugar de los eslabones más débiles de la cadena del narcotráfico, como los consumidores, pequeños agricultores, distribuidores menores, mulas' y tragones”, cita la sugerencia.

Actualmente el Gobierno no cuenta con equipos para implementar esa metodología de seguridad, según negaron varias autoridades en su momento. Sin embargo, desde 2011 existen varias denuncias, sobre todo de opositores, al respecto. 
La misma Naciones Unidas alertó, hace un par de meses sobre "la estrecha relación que existe entre los traficantes de drogas y las redes delictivas involucradas en el contrabando de armas de fuego, los secuestros, la trata de personas y otros delitos".

http://eju.tv/2013/03/eeuu-incluye-a-bolivia-en-lista-de-mayores-productores-de-droga-y-ueaumenta-cooperacin/

\section{EEUU incluye a Bolivia en lista de mayores productores de droga y UE aumenta cooperación}

Informes. La ONU, a través de la JIFE, reconoce en su informe anual 2012, presentado ayer, los logros alcanzados por Bolivia mediante su estrategia contra las drogas, especialmente en reducción de cultivos ilícitos de coca. Unión Europea (UE) dará a Bolivia Bs 220 millones.

EEUU incluye a Bolivia en lista de mayores productores de droga

\section{Los Tiempos}

Una plantación de cocales en el trópico de Cochabamba.

Estados Unidos incluyó ayer a Bolivia, Colombia y México entre las naciones donde se produce la mayor producción y tráfico de drogas, y donde se emite la mayor cantidad de precursores químicos y se lava la mayor cantidad de dinero, según Ap.

Al difundir su estrategia para el control del narcotráfico internacional correspondiente al 2012, el Departamento de Estado ubicó solamente a esas tres naciones latinoamericanas en cada uno de sus tres listados principales de países con mayores retos en la lucha antinarcóticos.

En contraposición a este reporte, ayer en Viena según Efe, la Organización de las Naciones Unidas (ONU) reconoció los logros alcanzados por Bolivia mediante su estrategia contra las drogas, especialmente la reducción de los cultivos ilícitos de coca, que en 2011 fue del 12 por ciento respecto al año anterior, pero critica la postura boliviana frente a la Convención de 1961 sobre drogas.

"La Junta observa con reconocimiento que en Bolivia la superficie de cultivo ilícito disminuyó el 12 por ciento, de 31.000 hectáreas en 2010 a 27.200 hectáreas en 2011 ”, señala la Junta Internacional de Fiscalización de Estupefacientes (JIFE) en su informe anual 2012, publicado ayer. 
Al respecto, el viceministro de Defensa Social, Felipe Cáceres, destacó que es la primera vez que la JIFE reconoce el esfuerzo y la política nacional de lucha contra el narcotráfico en todo el territorio nacional, que se realiza con recursos propios.

"Se están demostrando resultados positivos en materia de interdicción e erradicación de coca excedentaria, que por supuesto está destinada al problema del mercado ilegal”, manifestó al anotar que la comunidad internacional debe acompañar y apoyar estos esfuerzos y la política implementada por Bolivia, en el marco de la corresponsabilidad compartida y el respeto de la soberanía de cada país.

"En Bolivia hemos reconocido que no puede haber cero de coca, pero tampoco puede haber libre cultivos de coca excedente que va de forma ilegal. De manera responsable estamos llevando adelante un estudio integral de la hoja de coca para que el mundo entero sepa esos resultados”, dijo Cáceres.

El órgano de la ONU encargado de velar por el cumplimiento de los tratados internacionales contra las drogas (JIFE), en su informe "alienta al Gobierno de Bolivia a que siga redoblando sus esfuerzos por prevenir el cultivo ilícito".

Evo participará en sesión de la Comisión de Estupefacientes

El viceministro de Defensa Social y Sustancias Controladas, Felipe Cáceres, anunció ayer que el presidente Evo Morales participará el próximo 11 de maro, del $56^{\circ}$ Periodo de Sesiones de la Comisión de Estupefacientes de las Naciones Unidas que se realizará en Viena, Austria, con el fin de iniciar una campaña informativa sobre la despenalización de la hoja de coca.

Cáceres denunció que existen países que realizan una campaña contra Bolivia, asegurando que la readmisión en la Convención 1961 con la reserva del akulliku "significaría libre cultivo de coca, nuevos productores de coca, y por supuesto aumentaría la actividad ilícita de droga”.

La autoridad gubernamental descalificó esas versiones y aseguró que el Gobierno hará cumplir la estrategia de lucha contra el narcotráfico y reducción de cultivos excedentarios 2011-2015.

"Vamos a hacer una verdadera campaña, verdadera política del Gobierno nacional y mostraremos al mundo entero que la gestión se mide por resultados. Con menos recursos, con menos apoyo de la comunidad internacional”, manifestó Cáceres.

Reporte de EEUU

Tesis de Maestría 
El informe del Departamento de Estado de EEUU, presentado ayer, recordó que el presidente Barack Obama determinó el año pasado que Bolivia, Burma y Venezuela "fracasaron de forma evidente” en sus esfuerzos antinarcóticos.

Estados Unidos reconoció que Bolivia reportó la erradicación de al menos 10.000 hectáreas de cultivo de coca por segundo año consecutivo, no obstante "el cultivo ilegal de coca permanece alto, y el Gobierno boliviano tiene controles inadecuados para prevenir el desvio de la producción 'legal' de coca a la producción ilícita de cocaína”.

El documento identificó como uno de los factores en contra de Bolivia su política a considerar como lícito el cultivo de hasta 20.000 hectáreas de coca y su retiro de la Convención de Narcóticos de la ONU de 1961.

A Venezuela lo describe como un país clave de tránsito aéreo, terrestre y marítimo de cocaína, y a México, que progresó en cuanto a la reducción de homicidios relacionados al crimen organizado respecto al año anterior.

UE dará a Bolivia Bs 220 millones

PROGRAMA DE APOYO AL DESARROLLO INTEGRAL CON COCA 2014-2020.

Los Tiempos

Autoridades gubernamentales junto al embajador de la Unión Europea, Tomothy Torlot, ayer. Hernán Andia Los Tiempos

El embajador de la Unión Europea (UE), Timothy Torlot, confirmó ayer que el monto de colaboración para el Programa de

Apoyo al Desarrollo Integral con Coca en Bolivia 2014-2020 será de 24 millones de euros (220 millones de bolivianos), cuatro dígitos más de ayuda que el anterior periodo.

Torlot llegó ayer a Cochabamba para participar del taller de resultados del primer Programa de Apoyo al Control Social de la Coca (PACS) que concluyó en diciembre del año pasado. Al evento también asistiron dirigentes cocaleros de las seis Federaciones del Trópico de Cochabamba y de los Yungas de La Paz, además de los viceministros de Defensa Social, Felipe Cáceres, y de Coca, Dionisio Núñez. 
El diplomático informó que en la primera fase del PACS, la UE invirtió 20 millones de euros (180 millones de bolivianos) con los que se puso en marcha más de 1.000 proyectos que beneficiaron a más de 10 mil personas.

"El monto de colaboración en el caso del programa de Desarrollo Integral con Coca en su segunda etapa será de 24 millones de euros, son más o menos 220 millones de bolivianos, se trata de uno de los programas más importantes que la UE tiene en la región”, aseguró.

Indicó que la colaboración es una señal de que la UE desea continuar "caminando juntos en el marco de la responsabilidad compartida y bajo nuestro compromiso de cooperación histórica y exitosa con Bolivia”.

\section{PACS I}

La UE inviritó cerca de 10 millones de euros en el Programa de Apoyo al Control Social de la Coca (PACS) que se inició en 2008 y concluyó en 2013, en esta fase se conformó el registro biométrico de aproximadamente 43 mil productores de hoja de coca en el trópico de Cochabamba.

Además, se entregó seis infraestructuras con salas informáticas, amobladas y equipadas, desde donde las federaciones y organizaciones sociales de productores de coca planifican y ejecutan sus actividades de control social.

El programa también incluyó la capacitación de más de 2 mil dirigentes en gestión del autocontrol comunitario y resolución de conflictos.

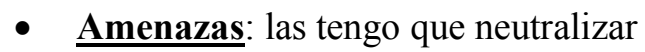

Permeabilidad de sus fronteras: La problemática de los países fronterizos que limitan con Bolivia constantemente serán un problema en constante crecimiento ya que si bien es un país productor de sustancias limita directamente con otros países productores de sustancias como lo son Perú y Paraguay, así mismo limita con países en donde el consumo de sustancias esta en contacte crecimiento como lo son Brasil y Argentina

SITUACION INTERNA: Situación Controlable

- Fortalezas: Las Tengo que aumentar/fomentar

Marco legislativo: En este caso consideramos que Bolivia presenta una serie de deficiencias en lo que respecta a la actual normativa que reprime las actividades relacionadas con el narcotráfico, existiendo 
hasta el momento la ley 1008 en donde se regula esta actividad y la del cultivo de la hoja de coca, considerándose que se deberá considerar la posibilidad en un futuro no muy lejano en legislar lo relacionado al espacio aéreo, precursores químicos, herramientas de investigación como lo son las escuchas telefónicas entre otros temas:

\section{$\underline{\text { http://eju.tv/2011/08/narcotrfico-bolivia-instalar-sistema-de-radar-para-vigilar-fronteras/ }}$}

\section{Narcotráfico. Bolivia instalará sistema de radar para vigilar fronteras}

En el marco de la lucha contra el narcotráfico, el Gobierno boliviano prevé instalar radares en sus fronteras para el control del espacio aéreo. El sistema entrará en correspondencia con los proyectos que implementan Brasil y Argentina, con el mismo propósito en sus territorios.

Bolivia instalará sistema de radar para vigilar fronteras

Proyecto. Los instrumentos se usarán para la lucha antinarcóticos.

El anuncio lo realizó el ministro de Gobierno, Sacha Llorenti, quien aseguró que el proyecto está a cargo del Ministerio de Defensa y que será acompañado con proyectos de ley que se refieren a la lucha antinarcóticos.

"Brasil va a tener (radares) y Vehículos Aéreos No Tripulados (Vant). Argentina va a disponer sus radares y nosotros tenemos que hacer lo propio. Lo que necesitamos es la radarización en nuestras fronteras con sus normas, capacidad aérea, helicópteros de lucha contra el narcotráfico e incrementar nuestros vínculos con otros países", dijo la autoridad.

Llorenti señaló que ese propósito va a requerir una fuerte inversión y, aunque no reveló la cantidad de recursos que se destinarán, dijo que el plan lo está trabajando "de manera más efectiva el Ministerio de Defensa".

El plan data del 2009. El entonces ministro de Gobierno, Alfredo Rada, indicó que la lucha antinarcótico "mejoraría en el país con la instalación de radares en la frontera con Argentina y Brasil. El proyecto que se trabaja a nivel binacional".

El proyecto acompañará a las seis leyes que se redactan en el campo de la Estrategia de Lucha Contra el Narcotráfico y Reducción de Cultivos Excedentarios de Coca 2011-2015 que redacta el Gobierno, además de las dedicadas a Control de la Coca y de Sustancias Controladas, que reemplazarán a la Ley 1008.

Según el viceministro de Defensa Social, Felipe Cáceres, se promueve la aprobación de las leyes de Extinción de Dominio de Bienes a Favor del Estado; de Incautación y Confiscación de Aeronaves y Destrucción de Pistas Clandestinas; de Pago de Informantes para la Lucha Contra el Narcotráfico; de 
Operaciones Contra el Microtráfico; de Complementación al Código de Procedimiento Penal; y de Interceptación de Comunicaciones con Fines Investigativos de Delitos.

"Todas estas normas son instrumentos indispensables para la lucha contra el narcotráfico y otros delitos. En el tema de derribo de aeronaves, se tiene que acompañar la capacidad aérea y la radarización en nuestras fronteras para identificar las aeronaves", destacó el ministro Llorenti.

FRONTERAS. El pasado mes, el embajador de Argentina en Bolivia, Horacio Macedo, informó que su país instalaría 20 radares en sus fronteras con Bolivia, Paraguay y Brasil, para contribuir de manera importante en la lucha contra el tráfico ilegal de drogas, en el marco del Decreto 1091 que tiene por objeto constituir el Operativo Escudo Norte, ideado por nuestro Ministerio de Seguridad.

El embajador brasileño en La Paz, Marcel Fortuna Biato, dijo que con autorización mutua de sobrevuelo vigilarán el espacio aéreo fronterizo. "Vamos a compartir cada información, lo que nos permitirá hacer operativos importantes. Queremos además mejorar esas condiciones con Perú, Chile y Paraguay", concluyó Sacha Llorenti.

Convenio trilateral: El ministro de Gobierno, Sacha Llorenti, afirmó que para la firma del convenio trilateral entre Brasil, Bolivia y Estados Unidos para la lucha contra el narcotráfico sólo faltan "detalles que por lo menos por el lado boliviano ya están resueltos".

Capacitación y profesionalización de fuerzas de seguridad

- Debilidades: las tengo que disminuir/erradicar

Controlar los cultivos de hojas de coca en territorio boliviano: Uno de los detalles más importantes a mi parecer que hacen que en este país andino se incremente día a día la actividad del narcotráfico es que debe existir un sistema judicial y político que regule con autoridad las áreas de cultivo de hojas de coca, siempre respetando que este arbusto está arraigado culturalmente, gran parte de las plantaciones son atiquizadas como materia prima para la elaboración de alguno de los derivados de COCAINA.

La regulación del espacio utilizado para el cultivo de la hoja de coca es uno de los temas mas debatidos en la agenda internacional, que si bien se intenta respetar la cultura Bolivia también se intenta efectuar que el presidente de dicho país tome conciencia que existe una porción suficiente que podría producir la hoja de coca suficiente para que se utilizada en el ámbito local para su masticado y su uso cotidiano. Es de importancia hacer constar que actualmente la ley 1008 es quien regula y establece el área total del país que está destinada para el cultivo de esta hoja, el cual debería ser en teoría de 12.000 hectáreas, llegando en este último tiempo a las 20.000 hectáreas, considerando ciertos estudios que no puede establecerse con exactitud la extensión actual utilizada para su cultivo ya que si bien se fue racionalizando el área de cultivo existen zonas en donde la plantación fue erradicada pero los pobladores de la zona volvieron a resembrar. 
Combatir la presencia de organizaciones o carteles criminales que se dedican al narcotráfico en nuestro país: Existen recortes periodísticos que dan cuenta sobre la presencias de representantes en suelo boliviano de carteles dedicados al narcotráfico tales como: Primer Comando de la Capital (PCC) y el Comando Vermelho:

http://eju.tv/2015/09/miembros-del-comando-vermelho-intentaron-sacar-casi-media-tonelada-dedroga-de-bolivia/

Miembros del Comando Vermelho intentaron sacar casi media tonelada de droga de Bolivia

Narcotráfico. Dos extranjeros iban a exportar cocaína valuada en \$us 2,7 millones.

Operativo. Parte de la droga confiscada a dos miembros del Comando Vermelho fue expuesta ayer en Santa Cruz. Ignacio Prudencio.

\section{La Razón / Iván Condori / Santa Cruz}

Los extranjeros que el martes iban a exportar vía aérea unos 400 kilos de clorhidrato de cocaína, valuada en aproximadamente \$us 2,7 millones, formaban parte del grupo jerárquico Comando de Vermelho, de Brasil, según reveló ayer el ministro de Gobierno, Carlos Romero.

La aeronave era piloteada por el brasileño Wagner Santulho (56), pero fue interceptada por agentes antidrogas en la comunidad de Loma Alta en el municipio de Santa Rosa, a 160 kilómetros al norte de Santa Cruz, en el intento de despegar de una pista clandestina. En la avioneta se encontró un cargamento de 320 kilos de cocaína, mientras que otros 80 kilos fueron hallados enterrados cerca del lugar del operativo antinarcóticos.

La avioneta sufrió un percance y ardió en llamas cuando los efectivos antidrogas llegaron al lugar e intentaron detenerla. El cargamento de droga se quemó al igual que la nave que tenía como destino Paraguay.

Organización. La organización criminal Comando Vermelho (Comando Rojo, CV, en portugués) fue fundada en 1979 por Cândido Mendes, en la cárcel brasileña de la Ilha Grande y se dedica, más que todo, al narcotráfico. En los 90 fue la estructura criminal que dominaba el comercio de drogas ilícitas en Río de Janeiro, pero el surgimiento de bandas rivales como el Primeiro Comando da Capital (PCC) y Amigos dos Amigos le restó poder, y muchos de sus líderes fueron asesinados o arrestados. En julio de 2011, cayó en Bolivia Marcos André Magalhaes Olivera, del $C V$.

Tesis de Maestría 
El director nacional de la Fuerza Especial de Lucha Contra el Narcotráfico (FELCN), coronel Santiago Delgadillo, relató que los narcotraficantes, al ser descubiertos por las fuerzas policiales, abrieron fuego contra los agentes y en la refriega fue herido de bala el piloto brasileño. Éste, cuando era trasladado a la ciudad de Santa Cruz, murió. Mientras tanto, el paraguayo identificado como Rilmer Eustaquio Ruiz, fue aprehendido en inmediaciones de la pista clandestina, se encontró un arma de fuego en su poder.

Romero informó que el piloto de la aeronave intervenida tenía doble nacionalidad, brasileña y paraguaya. En Paraguay era conocido con el nombre de Carlinho Flores, mientras que utilizaba los alias Presidente o Yacaré para operar en el mundo delictivo del narcotráfico.

El Gobierno atribuye al ahora fallecido Santulho un rosario de hechos delictivos, todos ligados al narcotráfico en Brasil, Paraguay y Bolivia. Por el momento, la Policía desconoce el tiempo que llegó a operar en el territorio nacional. "Wagner Santulho y Rilmer Eustaquio Ruiz, pertenecen al grupo jerárquico del Comando Vermelho, un cártel conocido y poderoso en el mundo delictivo que opera en Brasil”, advirtió la autoridad gubernamental.

De acuerdo con el Gobierno, en Bolivia, el brasileño Santulho fue sindicado de pilotear la avioneta con matrícula falsa interceptada con 114 kilos de cocaína en un operativo registrado el 10 de enero de 2005. El 3 de febrero de 2015 también fue relacionado a una avioneta paraguaya siniestrada en el norte de la capital cruceña.

En Brasil estuvo relacionado con el tráfico de al menos 175 kilos de crack (droga), que fue interceptado en el distrito de San Paulo, en un operativo realizado por agentes antidrogas el 24 de enero de 2009. En Paraguay, Santulho tiene tres antecedentes asociados al tráfico de sustancias controladas. En el primero, del 21 de enero de 2010 fue asociado al robo de una avioneta con matrícula argentina. Posteriormente, fue sindicado del robo de dos avionetas con matrícula paraguaya.

Caen tres narcos en vía a Chile

'Tragones'

Un bus con destino a Chile fue detenido en Pisiga en las pasadas horas, con fines investigativos, ya que entre los pasajeros se encontraban tres personas que traficaban cocaína en pequeñas cápsulas, las mismas que fueron halladas en un bolso. 
Control

El jefe de la policía antidrogas de Oruro, coronel Lisandro Patiño, señaló que el primer sospechoso fue encontrado en poder de un bolso con 42 cápsulas de cocaína. En su declaración dijo que ingirió en Cochabamba otra cantidad de droga. Luego aprehendieron a otras dos personas más.

$\underline{\text { http://eju.tv/2010/07/migran-a-bolivia-carteles-brasileos-de-droga/ }}$

\section{Migran a Bolivia carteles brasileños de droga}

Actividad: El diario paraguayo Última Hora dice que los integrantes del PPC y del Comando Vermelho migraron al país para tener mejor control del tráfico de droga.

\section{La Prensa}

Diario dice que migran a Bolivia carteles brasileños de droga

Los integrantes de los carteles brasileños Primer Comando de la Capital (PCC) y del Comando Vermelho, dedicados al tráfico de drogas y de armas, respectivamente, migraron de la población paraguaya Pedro Juan Caballero a Ciudad del Este, en ese mismo país, y a Bolivia, asegura el diario Última Hora.

Según ese periódico paraguayo, que a su vez cita a fuentes policiales, ese desplazamiento a Ciudad del Este se debe a que en la localidad fronteriza de Pedro Juan Caballero existe un intenso control de la Policía paraguaya y de las fuerzas de seguridad del Brasil tras el atentado que sufriera en días pasados el senador nacional Robert Acevedo.

En el caso de los migrantes al suelo boliviano, explica la nota, ello podría deberse a que haya un mejor control del tráfico de la cocaína que se traslada de ese país hacia el Paraguay, de donde, a su vez, sale a Brasil por vía aérea.

No es la primera vez que un medio de comunicación extranjero apunta a que integrantes de carteles se asientan en el país. El mes pasado fue detenido en Uruguay el narcotraficante brasileño José Paulo Vieira de Mello , quien, según el periódico La Voz, tenía intenciones de asentarse en Uruguay para traficar cocaina desde Bolivia y Paraguay hacia Brasil.

A ello se suman las declaraciones del asesor principal del presidente Luiz Inácio Lula da Silva, Marco Aurelio García, quien admitió que "escuché información, pero no la tengo directa, pero se rumorea que sí (que el PCC está en Bolivia). Sería en cierto modo comprensible, en la 
medida en que Bolivia puede ser, por una parte, una zona de producción, pero también es, seguramente, una zona de tránsito".

El diario paraguayo añade que las mismas fuentes indican que un grupo mínimo permanece aún en el Amambay, lo que hace que exista más calma porque en los primeros meses del año se dieron muchas ejecuciones entre ambos bandos por la lucha del poder absoluto en el negocio de las drogas.

La migración de los "soldados" (integrantes de los carteles) a otros puntos que no sea el Amambay (Paraguay) se debe a que sus líderes, tales como Jarvis Chiménes Pavão y Antonio Caballero, más conocido como Capilho, fueron capturados por los agentes antidrogas.

Uno de los componentes del departamento de Investigación de Delitos del Amambay explicó a ese diario que en los últimos meses en la zona no se registró hechos de muertes por ajustes de cuentas como en el pasado reciente.

La localidad de Pedro Juan Caballero cerró el pasado año con una alta estadística de muertes por encargo y estuvo a punto de llegar a las cien muertes por ajusticiamiento.

Sin embargo, ese flagelo se trasladó a la capital del Alto Paraná, donde ya se dio un número todavía no precisado de muertes entre ciudadanos brasileños cuyos cuerpos fueron arrojados en zonas pocos transitadas.

Hasta ahora ninguno de los dos grupos de narcotraficantes brasileños logró obtener el control absoluto del tráfico de estupefacientes.

Las fuentes policiales del Paraguay también consideran que la lucha de poder por ambos territorios se podría traducir en más ejecuciones.

El atentado sufrido por Robert Acevedo fue el punto de inflexión para que se reforzara la seguridad en la zona.

En Perú se confisca una tonelada de droga y caen 3 peruanos y un boliviano

La policía del Perú secuestró una tonelada de cocaína a cuatro peruanos y un boliviano en el parque industrial Pampa Inalámbrico, en la región de Moquegua, en la costa sur de ese país, informó la Dirección Antidrogas de la Policía Nacional (Dirandro). Los detenidos, entre ellos dos mujeres, son sospechosos de integrar una banda dedicada al narcotráfico. 
De acuerdo con las primeras investigaciones, los aprehendidos pretendían llevar el cargamento hacia Bolivia por vía terrestre. Los peruanos fueron identificados como Weyder C. C., Danilo T. Calderón, Margarita T. P. y Rosa T. P., y el boliviano como Emilio V. S. Todos ellos serán puestos a disposición de las autoridades judiciales peruanas.

La FELCN se incauta de narcocamioneta y una fábrica de droga

El fin de semana, dos operativos antidroga en Cochabamba y Santa Cruz permitieron, en el primer caso, incautar 115 kilos de cocaína que estaban siendo transportados en una camioneta, y en el segundo, destruir una fábrica de droga que producía entre 30 y 50 kilos por día.

En el caso de la "Llajta", un operativo rutinario en la ruta Epizana-Totora permitió dar con el vehículo en cuyas puertas, carrocerías y techo había dobles fondos en los que se escondía la droga. La intervención en Santa Cruz fue ejecutada a 28 kilómetros de Santa Rosa del Sara, donde se descubrió una factoría de droga. Dos colombianos y un boliviano fueron detenidos y ayer fueron remitidos al penal de Palmasola, por disposición judicial.

\section{http://eju.tv/2012/06/evo-y-la-internacional-del-narcotrfico/}

\section{Evo y la Internacional del Narcotráfico}

El presidente Evo Morales se empeña en la política de la negación. Luego de que la canciller de Colombia, María Ángela Holguín, confirmara que hay cárteles colombianos operando en Bolivia, el gobierno activó a varios funcionarios que saltaron agresivamente a la palestra para tildarla de "vocera de la DEA" y para reiterar la negación oficial de esa presencia.

El régimen cocalero no está dando los pasos necesarios para hacer frente a la instalación de lo que el analista Humberto Vacaflor denomina la "Internacional del Narcotráfico". Antes bien, la permanente expansión de la frontera cocalera, tolerada y hasta promovida por la administración evista, ofrece el caldo de cultivo ideal para la incursión de los

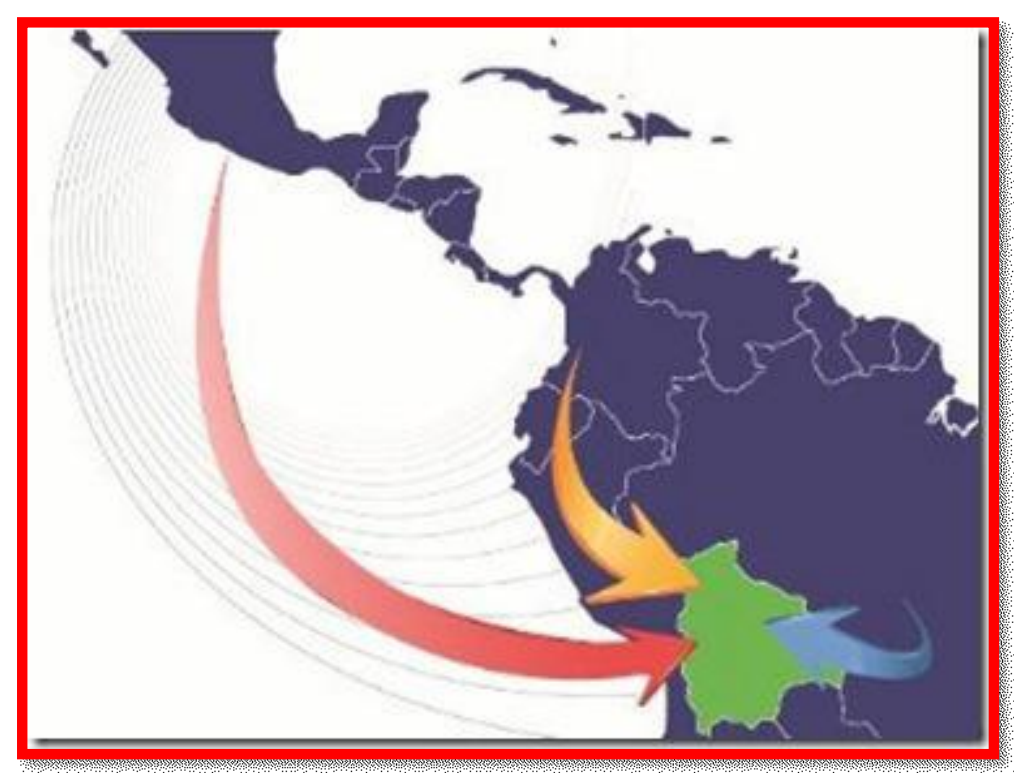


cárteles en territorio boliviano.

El modus operandi de estas narco-mafias es la creación de feudos, los mal llamados "territorios liberados", que más valdría calificar de esclavizados.

Así sucede en México y sucedió en Colombia, donde la dura politica de Álvaro Uribe logró revertir amplias zonas del país al dominio estatal, obligando a los narcos a migrar a otras latitudes.

¿No es precisamente este fenómeno de las narco-republiquetas el que estamos viendo crecer en Bolivia durante la Era Evo?

En el bastión presidencial del Chapare apenas el 5\% de la coca cultivada va al acullico (ONU dixit), existen comunidades donde la Fuerza Especial de Lucha Contra el Narcotráfico tiene vedado el ingreso, y acaba de descubrirse en una sola población la friolera de 250 laboratorios para la fabricación de cocaína.

Y es que la problemática de la coca es asunto demasiado grave para dejarla sólo en manos de los cocaleros.

Agreguemos a esto la información facilitada desde la cárcel por el general René Sanabria, sobre la presunta protección oficial a funcionarios vinculados con el narcotráfico, y tendremos un panorama completo de la dificil situación boliviana.

Todo indica que el gobierno cocalero sigue un rumbo de colisión que tarde o temprano lo llevará a estrellarse con la comunidad internacional... 


\section{CONCLUSIONES}

Teniendo en cuenta la totalidad de información recabada hasta el momento en lo que respecta al funcionamiento e incremento de las actividades criminales relacionadas directamente con el Narcotráfico en nuestro vecinos país de Bolivia estamos en condiciones de afirmar que efectivamente este país presenta una serie de falencias y/o defectos que hacen que sea un lugar acorde para el asentamiento del crimen organizado, más un en su faceta del tráfico de estupefacientes a gran escala, estas falencias pueden detallarse de la siguiente manera:

$\checkmark$ Deficiencia en la racionalización y el control de la producción de la hoja de coca, la cual es un los insumos más importantes al momento de elaborar estupefacientes, siendo que actualmente esta producción tiene un excedente considerable con relación a las 12.000 hectáreas establecidas en la ley 1008 del estado plurinacional boliviano.

$\checkmark$ La ausencia de una de las organización internacionales más especializadas en la lucha contra el narcotráfico como lo es la DEA hacen que esta actividad se vea favorecida, ya que esta entidad no tan solo hacia un aporte monetario, sino también logístico y de capacitación a las fuerzas de seguridad inherentes en la materias propias de Bolivia, esto se debe por la mala relación existen en su actual mandatario Evo Morales y las autoridades de los Estados Unidos.

Además de ser un país productor de estupefacientes Bolivia se ve desfavorecido por su extrema cercanías con países como Brasil y Argentina, que son el primer y segundo país mas consumir de cocaína y sus derivados de Sudamérica, al existir una excesiva demanda de estas sustancias su producción va en aumento. Otro de sus puntos desfavorables es su límite fronterizo con PERU el cual es uno de los mayores productores de hoja de coca del mundo y por ende uno de los mayores productores de cocaína existentes hasta el momento. De igual modo presenta un límite fronterizo con el país que más produce marihuana en Sudamérica como lo es Paraguay: Las porosas y largas fronteras de Bolivia (con 3.420 kilómetros, la frontera entre Bolivia y Brasil es $200 \mathrm{~km}$ más larga que la que México comparte con Estados Unidos) y la falta de controles migratorios, garantizan que Bolivia sea un centro de contrabando y por lo tanto extremadamente atractivo para el COT. Las fronteras porosas implican que no sólo las drogas pueden entrar y salir del país, sino también los precursores químicos y la mano de obra extranjera necesaria para procesarlos. Los criminales internacionales, incluso los que tienen órdenes nacionales de arresto, también pueden ingresar y salir de Bolivia con suma facilidad. La directora de la autoridad migratoria de Bolivia, Cosset Estenssoro, reveló que Bolivia no tiene información sobre órdenes 
nacionales de arresto, sino sólo sobre las órdenes internacionales registradas en la Interpol. Esto significa que los narcotraficantes colombianos con órdenes nacionales de arresto pueden entrar a Bolivia sin temor a ser detenidos, algo confirmado por fuentes del hampa en Medellín.

$\checkmark$ Además de ser un país productor y de tránsito, el consumo de sustancias estupefacientes en este territorio constantemente va en aumento, lo cual genera un amplio problema para el estado ya que tiene que combatir esta modalidad delictiva en los distintos escenarios que se le presenta (productor, tránsito y consumidor).

$\checkmark \mathrm{Su}$ legislación sobre ciertos aspectos ligados directamente e indirectamente al narcotráfico presenta falencias, tales como ESCASO CONTROL DEL ESPACIO AEREO: Los narcotraficantes prefieren transportar sus cargamentos por vía aérea, siempre que sea posible. Los aviones pueden llevar grandes cargas, y las drogas pasan a través de muy pocas manos, lo que reduce los costos, así como los riesgos de traición o incautación. Perú, Bolivia y Paraguay tienen poca cobertura de radares y casi ningún equipo para interdicción aérea, lo que significa que sus cielos están completamente despejados. Este es un factor importante que hace de Bolivia un centro de tráfico de drogas y un gran atractivo para el COT. Bolivia sabe sobre el tráfico aéreo que pasa intacto sobre su territorio. El 22 de abril de 2014, el presidente Evo Morales firmó la "Ley de Seguridad y Defensa del Espacio Aéreo Boliviano", que permite el derribo de vuelos con drogas. Pero debido a que Bolivia carece de radares para rastrear este tipo de vuelos, así como de los aviones de combate para interceptarlos, la ley es poco más que una declaración de intenciones. Tanto Brasil como Argentina tienen mejor control sobre su espacio aéreo, pero todavía existe un tráfico aéreo importante hacia ambos países, donde algunos de los vuelos están legalmente declarados, mientras que otros están probando suerte. En Brasil, para minimizar el riesgo de interceptación, algunos pilotos que cruzan desde Bolivia emplean una táctica conocida como "bombardeo". Esto implica empacar las drogas en contenedores especiales y de alto impacto que puedan sobrevivir a una caída desde un avión en vuelo. Esto permite que la aeronave no tenga que aterrizar para bajar la carga, lo que reduce significativamente el riesgo de interceptación e incautación del preciado cargamento.

$\checkmark$ Carencia de Estrategias de Seguridad: CONALTIDestá tratando de armar una estrategia para enfrentar el tráfico internacional de drogas. Si bien se están implementando algunas medidas, incluyendo la reactivación del Observatorio Boliviano de Drogas (OBD), una estrategia integrada de lucha contra el narcotráfico — que incluya niveles realistas de financiación — aún 
está en pañales. La UE ha dado su apoyo al gobierno de Bolivia, buscando compensar parte del déficit con la pérdida de dinero de USAID.

Por todo lo expuesto estamos en condiciones de afirmar que Bolivia representa en nuevo epicentro del narcotráfico en Sudamérica, lo cual afecta directamente el comportamiento de esta actividad criminal dentro del territorio de nuestro país por el territorio fronterizo que comparten, ya que al acrecentarse la producción de estupefacientes en Bolivia, Argentina pasa a ser casi obligadamente como un lugar de tránsito para exportar estas sustancias estupefacientes hacia Europa, Asia y África, entre otros destinos. Ello sin contar que el consumo de este tipo de sustancias en nuestro país también está creciendo rápidamente.

Por tal motivo se deberá hacer uso de la Inteligencia Estratégica para efectuar una lectura, análisis y estudio de esta problemática a nivel nacional, regional, continental e internacional, considerándose de importancia comenzar a abordar este flagelo desde el punto de vista de la cooperación entre países ya que el problema a ser transnacional afecta varios países al mismo tiempo. 


\section{BIBLIOGRAFIA}

Lic. German Sergio Martínez (2008) "IV CONGRESO DE RELACIONES INTERNACIONALES” - LA PLATA PCIA DE BS. AS. - ARGENTINA

BULCAURF, Pablo y VAZQUEZ Juan Cruz "Narcotráfico: Dimensiones y Elementos para su análisis" - disponible en http://www.saap.org.ar/esp/docs-congresos/congresossaap/VII/programa/paneles/e/e1/bulcourf-vazquez.pdf

http://es.insightcrime.org/quienes-somos

INSIGCRIMEN (2014) "El desafío de Evo: Bolivia epicentro del narcotráfíco" - MC DERMOTT, Jeferemy, disponible en https://www.dropbox.com/s/pov912ncjsprepa/bolivia desafio drogas.pdf? $\mathrm{dl}=0$

http://www.noticias24.com/actualidad/noticia/19475/bolivia-acusa-a-la-dea-de-conspiracion-ysuspende-sus-operaciones/

INSIGCRIMEN (2014) "El desafío de Evo: Bolivia epicentro del narcotráfico" - MC DERMOTT, Jeferemy, disponible en https://www.dropbox.com/s/pov912ncjsprepa/bolivia_desafio_drogas.pdf?dl=0

http://escuelasuperior.com.ar/instituto/wp-content/uploads/2017/05/InteligenciaEstrategica.pdf

Gral. Washington Plattm (1983) "Inteligencia Estratégica” - Argentina: Struhart

https://www.academia.edu/5623306/CRIMEN ORGANIZADO

https://www.interpol.int/es/Criminalidad/Delincuencia-organizada/Delincuencia-organizada

R. Thomas Naylor, "Mafias, myths, and markets: on the theory of enterprise crime", Transnational Organized Crime, vol. 3, núm. 3 (Otoño de 1997), pág. 4

http://es.calameo.com/read/000903453c1552d2e9dab)

http://es.calameo.com/read/00353134029a1fa16d290

http://www.ub.edu.ar/centros de estudio/ceprede/CEPREDE 0203 2015.pdf

http://www.un.org/es/sections/what-we-do/index.html

http://www.un.org/es/comun/docs/?symbol=A/RES/66/183

http://www.unodc.org/unodc/en/treaties/single-convention.html

http://www.unodc.org/unodc/en/treaties/psychotropics.html

http://www.unodc.org/unodc/en/treaties/illicit-trafficking.html

http://www.unodc.org/unodc/commissions/CND/ 
https://www.incb.org/

https://www.un.org/ruleoflaw/es/thematic-areas/transnational-threats/drug-trafficking/

https://bibliotecadigital.csjn.gov.ar/Constitucion-de-la-Nacion-Argentina-Publicacion-delBicent.pdf

Gómez, Raúl Angel (2013). LA LEGISLACIÓN PENAL ARGENTINA SOBRE DROGAS. UNA APROXIMACIÓN HISTÓRICA. V Congreso Internacional de Investigación y Práctica Profesional en Psicología XX Jornadas de Investigación Noveno Encuentro de Investigadores en Psicología del MERCOSUR. Facultad de Psicología - Universidad de Buenos Aires, Buenos Aires

http://lapatriaenlinea.com/?nota=75169

http://www.cancilleria.gob.bo/webmre/sites/default/files/libros/13\%20estrategia $\% 201$ ucha $\% 20$ co ntra\%20el\%20narcotrafico.Pdf

http://www.pensamientopenal.com.ar/system/files/2016/07/doctrina43787.pdf

Meryl Thiel1 (2014) “Acullico y narcotráfico - Cuestionar la injerencia" - disponible en https://www.bolivianstudies.org/revista/11.1/11.01.008.Thiel.pdf

https://riull.ull.es/xmlui/bitstream/handle/915/915/El\%20crimen\%20organizado\%20y\%20el\%20 narcotrafico $\% 20 \mathrm{en} \% 20 \mathrm{el} \%$ 20panorama $\% 20$ internacional.pdf?sequence $=1$

UNODC (2014) "Resumen ejecutivo del Informe Mundial Sobre las Drogas". Oficina de las Naciones

Unidas contra la Droga y el Delito, p. 4

Fontana, Andrés (2003). Nuevas amenazas: implicancias para la Seguridad Internacional y el empleo de las Fuerzas Armadas. Documento de Trabajo $\mathrm{N}^{\circ} 103$, Universidad de Belgrano. Disponible en la red: http://www.ub.edu.ar/investigaciones/dt_nuevos/103_fontana.pdf

Stephanie Marie Antelo Dabdoub “El Narcotráfico en Bolivia - Un estudio comparado del mandato presidencial de Evo Morales Ayma y el periodo neoliberal de 1993 a 2003" Universidad de Palermo Facultad de Ciencias Sociales - Licenciatura en Relaciones Internacionales Tesina de Grado

Ley 1008 del régimen de coca y sustancias controladas, artículo 19, aprobada el 19 de julio de 1988. La Paz, Bolivia

Stephanie Marie Antelo Dabdoub "El Narcotráfico en Bolivia - Un estudio comparado del mandato presidencial de Evo Morales Ayma y el periodo neoliberal de 1993 a 2003" Universidad de Palermo Facultad de Ciencias Sociales - Licenciatura en Relaciones Internacionales Tesina de Grado 
https://www.unodc.org/documents/crop-

monitoring/Bolivia/Bolivia_Informe Monitoreo_Cultivos_Coca_2015.pdf

Jeremy Mac Dermott (2014) "El Desafío de Evo Morales - Bolivia el epicentro de la droga" In Shing Crime http://es.insightcrime.org/investigaciones/bolivia-nuevo-epicentro-narcotrafico$\underline{\text { suramerica }}$

http://www.ub.edu.ar/centros de estudio/ceprede/CEPREDE 0203 2015.pdf

http://www.ub.edu.ar/centros_de_estudio/ceprede/CEPREDE_02_03_2015.pdf

http://www.ub.edu.ar/centros de estudio/ceprede/CEPREDE 02 03 2015.pdf

http://www.un.org/es/sections/what-we-do/index.html

http://www.un.org/es/comun/docs/?symbol=A/RES/66/183

http://www.unodc.org/unodc/en/treaties/single-convention.html

http://www.unodc.org/unodc/en/treaties/psychotropics.html

http://www.unodc.org/unodc/en/treaties/illicit-trafficking.html

http://www.unodc.org/unodc/commissions/CND/

https://www.incb.org/

https://www.un.org/ruleoflaw/es/thematic-areas/transnational-threats/drug-trafficking/

https://bibliotecadigital.csjn.gov.ar/Constitucion-de-la-Nacion-Argentina-Publicacion-del-

Bicent.pdf

Gómez, Raúl Angel (2013). LA LEGISLACIÓN PENAL ARGENTINA SOBRE DROGAS. UNA APROXIMACIÓN HISTÓRICA. V Congreso Internacional de Investigación y Práctica Profesional en Psicología XX Jornadas de Investigación Noveno Encuentro de Investigadores en Psicología del MERCOSUR. Facultad de Psicología - Universidad de Buenos Aires, Buenos Aires

http://lapatriaenlinea.com/?nota=75169

http://www.cancilleria.gob.bo/webmre/sites/default/files/libros/13\%20estrategia $\% 201$ ucha $\% 20$ co ntra\%20el\%20narcotrafico.pdf

http://www.pensamientopenal.com.ar/system/files/2016/07/doctrina43787.pdf

Meryl Thiel1 (2014) "Acullico y narcotráfico - Cuestionar la injerencia" - disponible en https://www.bolivianstudies.org/revista/11.1/11.01.008.Thiel.pdf

https://riull.ull.es/xmlui/bitstream/handle/915/915/El\%20crimen\%20organizado\%20y\%20el\%20 narcotrafico $\% 20 \mathrm{en} \% 20 \mathrm{el} \%$ 20panorama $\% 20$ internacional.pdf? sequence $=1$ 
UNODC (2014) "Resumen ejecutivo del Informe Mundial Sobre las Drogas". Oficina de las Naciones

Unidas contra la Droga y el Delito, p. 4

Fontana, Andrés (2003). Nuevas amenazas: implicancias para la Seguridad Internacional y el empleo de las Fuerzas Armadas. Documento de Trabajo $\mathrm{N}^{\circ}$ 103, Universidad de Belgrano. Disponible en la red: http://www.ub.edu.ar/investigaciones/dt nuevos/103 fontana.pdf

Stephanie Marie Antelo Dabdoub "El Narcotráfico en Bolivia - Un estudio comparado del mandato presidencial de Evo Morales Ayma y el periodo neoliberal de 1993 a 2003" Universidad de Palermo Facultad de Ciencias Sociales - Licenciatura en Relaciones Internacionales Tesina de Grado

Ley 1008 del régimen de coca y sustancias controladas, artículo 19, aprobada el 19 de julio de 1988. La Paz, Bolivia

Stephanie Marie Antelo Dabdoub “El Narcotráfico en Bolivia - Un estudio comparado del mandato presidencial de Evo Morales Ayma y el periodo neoliberal de 1993 a 2003" Universidad de Palermo Facultad de Ciencias Sociales - Licenciatura en Relaciones Internacionales Tesina de Grado

https://www.unodc.org/documents/cropmonitoring/Bolivia/Bolivia Informe Monitoreo Cultivos Coca 2015.pdf

https://www.unodc.org/documents/cropmonitoring/Bolivia/Bolivia_Informe_Monitoreo_Cultivos_Coca_2015.pdf Jeremy Mac Dermott (2014) "El Desafío de Evo Morales - Bolivia el epicentro de la droga" In Shing Crime http://es.insightcrime.org/investigaciones/bolivia-nuevo-epicentro-narcotrafico$\underline{\text { suramerica }}$ 